Universidade de Brasília

Instituto de Ciências Humanas

Departamento de Geografia

Programa de Pós-Graduação em Geografia

\author{
UNIVERSIDADE DE BRASÍLIA \\ PÓS-GRADUAÇÃO EM GEOGRAFIA
}

\title{
FERROVIAS MOGIANA E NORTE E SUL EM TERRITÓRIO GOIANO: A GEOPOLÍTICA DOS TRANSPORTES
}

Marajá João Alves de Mendonça Filho

Tese de Doutorado 
Universidade de Brasília

Instituto de Ciências Humanas

Departamento de Geografia

Programa de Pós-Graduação em Geografia

\author{
UNIVERSIDADE DE BRASÍLIA \\ PÓS-GRADUAÇÃO EM GEOGRAFIA
}

\title{
FERROVIAS MOGIANA E NORTE E SUL EM TERRITÓRIO GOIANO: A GEOPOLÍTICA DOS TRANSPORTES
}

Marajá João Alves de Mendonça Filho

Orientadora: Nelba Azevedo Penna

Co-Orientadora: Ignêz Costa Barbosa Ferreira

Tese de Doutorado

Brasília-DF: Março / 2015 


\title{
UNIVERSIDADE DE BRASÍLIA PÓS-GRADUAÇÃO EM GEOGRAFIA
}

\section{FERROVIAS MOGIANA E NORTE E SUL EM TERRITÓRIO GOIANO: A GEOPOLÍTICA DOS TRANSPORTES}

\author{
Marajá João Alves de Mendonça Filho
}

Tese de Doutorado submetida ao Departamento de Geografia da Universidade de Brasília, como parte dos requisitos necessários para a obtenção do Grau de Doutor em Geografia, área de concentração Gestão Ambiental e Territorial.

Aprovado por:

Nelba Azevedo Penna, Doutora (UNB)

(Orientadora)

Marília Steinberger, Doutora (UNB)

(Examinadora Interna)

Rafael Sanzio Araújo dos Anjos, Doutor (UNB)

(Examinador Interno)

Renato Araújo Teixeira, Doutor (IFG)

(Examinador Externo)

Glória Maria Vargas Lopes de Mesa, Doutora (UNB)

(Examinadora Interna)

Ivanilton José de Oliveira, Doutor (UFG)

(Examinador Externo - Suplente)

Brasília-DF, 04 de março de 2015. 
[ficha catalográfica]

MENDONÇA FILHO, MARAJÁ JOÃO ALVES

A Geografia dos Transportes: ferrovias Mogiana e Norte Sul em território goiano, 182 p., 297 mm, (UnB-IH/GEA, Doutor, Geografia e Transportes, 2015).

Tese de Doutorado - Universidade de Brasília. Instituto de Ciências Humanas / Departamento de Geografia
1. Ferrovias
2. Transportes e competitividade
3. Transformação territorial
4. Goiás entroncamento logístico
I. UnB-CDS
II. Título (série)

É concedida à Universidade de Brasília permissão para reproduzir cópias desta tese e emprestar ou vender tais cópias somente para propósitos acadêmicos e científicos. $\mathrm{O}$ autor reserva outros direitos de publicação e nenhuma parte desta tese de doutorado pode ser reproduzida sem a autorização por escrito do autor. 
Universidade de Brasília

Instituto de Ciências Humanas

Departamento de Geografia

Programa de Pós-Graduação em Geografia

Ao Senhor Deus Todo Poderoso, a quem devo toda honra e toda a glória, pela sua Fidelidade e Eterna Bondade que sempre assistiu a mim e minha família, pelo Socorro bem presente na hora da angústia, pela Coluna e Baluarte que sustenta a minha vida, o Motivo da minha canção, o Refúgio em quem confio, Fonte de toda boa dádiva e de todo dom perfeito, o Pai das Luzes, a Porção da minha herança, o Arrimo da minha sorte, Aquele que me faz ver o caminho da vida, a Presença em que há a plenitude de alegria, a Destra que proporciona delícias perpetuamente, o Único Onisciente, Onipotente e Onipresente, o Alfa e o Ômega, o Princípio e o Fim. 
Universidade de Brasília

Instituto de Ciências Humanas

Departamento de Geografia

Programa de Pós-Graduação em Geografia

\section{AGRADECIMENTOS}

Primeiramente a Deus pela vida, pelo sustento e proteção, e por até aqui ter abençoado a mim e a minha família. A minha esposa Olívia pela incansável compreensão dedicação e pelo amor. Aos meus filhos Thainan e Gabriel pela força em todos os momentos e por entenderem a minha ausência mesmo quando presente, em função das inúmeras horas dedicadas para o cumprimento das obrigações do doutorado. Aos meus pais pela vida, pela educação e pela incansável torcida. Aos meus demais familiares pela apoio e camaradagem. Aos amigos, aos colegas de trabalho e aos meus alunos, pelo companheirismo e energia na caminhada. Em especial, agradeço as minhas orientadoras, Dra. Nelba e Dra. Ignêz, pela paciência, compreensão e apoio ao aluno trabalhador.

Agradeço aos membros da banca avaliadora Dra. Nelba Azevedo Penna, Dra. Marília Steinberger, Dra. Glória Maria Vargas Lopes de Mesa, Dr. Rafael Sanzio Araújo dos Anjos e Dr. Renato Araújo Teixeira, pelo rigor e precisão acadêmica, pelas contribuições científicas e pela confiança. Destaco a gentileza, o profissionalismo e a generosidade do Dr. Renato pelas zelosas e criativas contribuições e por ter participado da banca, mesmo sem o devido suporte administrativo previsto. Um exemplo de ser humano! A minha querida Profa. Dra. Ignez Costa Barbosa pela incansável compreensão, humanidade e profissionalismo no trato acadêmico. Foi uma honra e um privilégio! Ao Coordenador do Doutorado, Dr. Osmar Abílio por ter abrilhantado a defesa da tese com a sua ilustre presença. Muito obrigado!

Aos professores das disciplinas obrigatórias e optativas: Dr. Neio Lúcio, Dra. Ignez Costa, Dra. Marília Peluso, Dra. Lucia Cony, Dra. Glória Maria, pelas inestimáveis contribuições acadêmicas durante as aulas. Joias preciosas do conhecimento! Ao Jorge, ao Jorginho, ao Agnelo, a Simoni, e aos demais colaboradores do Departamento de PósGraduação em Geografia pelo fundamental trabalho desenvolvido em prol do funcionamento administrativo e pelo suporte acadêmico aos alunos e professores. Vocês foram verdadeiros "anjos da guarda" durante essa longa e exaustiva caminhada.

A Copiadora Express - UNIVERSO / Goiânia, pelo fornecimento de todo o material impresso necessário a execução do doutorado. Sempre em nível de excelência! 
Universidade de Brasília

Instituto de Ciências Humanas

Departamento de Geografia

Programa de Pós-Graduação em Geografia

Não fosse o SENHOR, que esteve ao nosso lado, Israel que o diga.

Salmo 124: 1 
RESUMO: O presente trabalho analisa o processo histórico de instalação das ferrovias no território brasileiro para a compreensão da sua importância na integração e na competitividade econômica, o que culminou com a formação do novo entroncamento logístico nacional em Goiás. Para tanto, o trabalho foi distribuído em quatro capítulos. O primeiro analisa a implantação da rede ferroviária e a formação do território nacional: em três momentos: a logística colonial, as ferrovias imperiais e as ferrovias republicanas. O segundo capítulo contempla as modificações no território goiano, diante da chegada dos trilhos da Mogiana a partir da ótica do avanço das fronteiras. Para isso fez-se um resgate bibliográfico dos principais autores que abordam Goiás e as fronteiras, seguido pelo enquadramento do Brasil neste cenário, a fim de compreender a estratégia logística de transportes do país especialmente as ferrovias. No terceiro capítulo avaliou-se a ferrovia Norte - Sul e seus legados na transformação do Brasil Central, com ênfase no território goiano. Nesta etapa, contemplou-se a constituição histórica da instalação e as operações da ferrovia Norte - Sul no trecho goiano, e os legados econômicos proporcionados pelas ferrovias. O quarto capítulo aborda a ferrovia no desenvolvimento brasileiro a partir da modernização dos transportes e a competitividade logística. Nele contempla-se o entendimento da modernização do território goiano a partir das ferrovias, o seu papel na economia e a competitividade logística a partir do modal de transporte ferroviário, que é o transporte terrestre com menor custo disponível na atualidade. Dentre os resultados alcançados, nota-se a ambiguidade entre a importância das ferrovias para a manutenção da competitividade do Brasil diante do mercado internacional e a insuficiente estrutura ferroviária do país. Além disso, constatou-se que a falta de articulação entre as redes férreas existentes agrava a situação logística, o que será atenuado com a formação do novo entroncamento logístico ferroviário em Goiás, resultando em novas possibilidades de rotas para as mercadorias brasileiras, com consequente diminuição no preço do frete.

PALAVRAS CHAVE: ferrovias, geopolítica, competitividade logística, território e Goiás. 


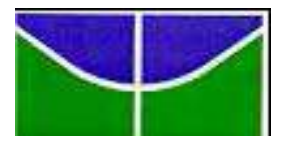

Universidade de Brasília

Instituto de Ciências Humanas

Departamento de Geografia

Programa de Pós-Graduação em Geografia

\begin{abstract}
The present work analyzes the historical process of installation of the railways in Brazilian territory to the understanding its importance in the integration and economic competitiveness, which culminated in the formation of the new national logistics junction in GOIAS. Therefore, the work was distributed in four chapters. The first examines the deployment of the railway network and the formation of the national territory: in three stages: the colonial logistics, the imperial railways and the republican railroads. The second chapter deals with the changes in the Goiás territory, before the arrival of the rails of the Mogiana from the perspective of the advance of borders. For this became a ransom of bibliographic main authors who deal with Goiás and borders, followed by the framework of Brazil in this scenario, in order to understand the logistics strategy for transport in the country especially the railroads. In the third chapter we evaluated the Northern railway - South and its legacy in the transformation of Central Brazil, with emphasis in Goiás. In this step, looked at the historical constitution of the installation and the operations of the the Northern railway - South in Goiás stretch, and the economic legacy provided by the railroads. The fourth chapter discusses the railroad development in Brazilian from the modernization of transport and logistics competitiveness. It deals with the understanding of the modernization of the Goiás from railroads, its role in the economy and competitiveness logistics from the modal of rail transport, which is the land transport with lower cost available nowadays. Among the results, there is the ambiguity between the importance of the railroads to maintain the competitiveness of Brazil in the international market and the insufficient railway infrastructure of the country. In addition, it was noted that the lack of coordination between the railway networks existing exacerbates the logistics situation, which will be mitigated by the formation of the new rail logistics junction in Goiás, resulting in new opportunities for routes to the Brazilian goods, with a consequent reduction in the price of the freight.
\end{abstract}

KEYWORDS: railways, geopolitics, logistics competitiveness, territory and Goiás . 


\section{SUMÁRIO}

LISTA DE QUADROS..........................................................................................

LISTA DE TABELAS............................................................................................

LISTA DE GRÁFICOS ................................................................................................

LISTA DE FIGURAS................................................................................................

LISTA DE ABREVIATURAS E SIGLAS......................................................................

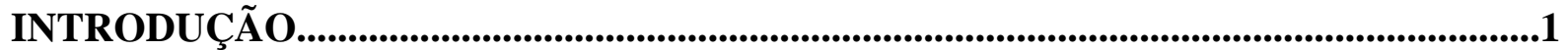

1 A IMPLANTAÇÃo DA REDE FERROVIÁRIA E A FORMAÇÃO DO TERRITÓRIO NACIONAL..............................................................................................99

1.1 O CONTEXTO GEOPOLÍTICO BRASILEIRO E SUAS REDES LOGÍSTICAS............11

1.2 A LOGÍSTICA COLONIAL BRASILEIRA: ESTRADAS REAIS, RIOS E PORTOS ...26

1.3 A MONTAGEM DA REDE FERROVIÁRIA NO BRASIL IMPÉRIO............................. 30

1.4 O BRASIL REPÚBLICA: A EXPANSÃO DA REDE E O CONTROLE PÚBLICO E PRIVADO DAS FERROVIAS.............................................................................

2 GOIÁS NO CENÁRIO DE INTEGRAÇÃo NACIONAL E O PAPEL DO TRANSPORTE FERROVIÁRIO.................................................................................... 63

2.1 A FERROVIA MOGIANA E A INTEGRAÇÃO DE GOIÁS COM O SUDESTE.......... 63

2.2 A INTEGRAÇÃO FERROVIÁRIA NO CENTRO OESTE............................................. 77

2.3 A MARCHA PARA O OESTE E A CRIAÇÃO DE GOIÂNIA: BREVES

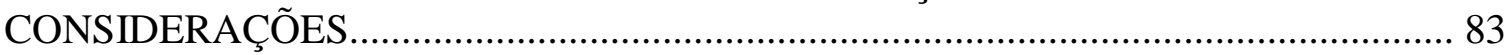

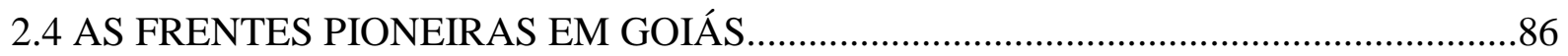

3 FERROVIA NORTE SUL NO TERRITÓRIO GOIANO: PERSPECTIVAS E

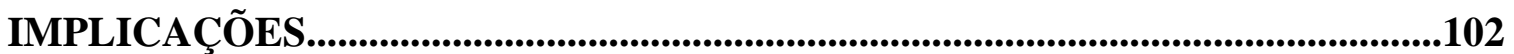

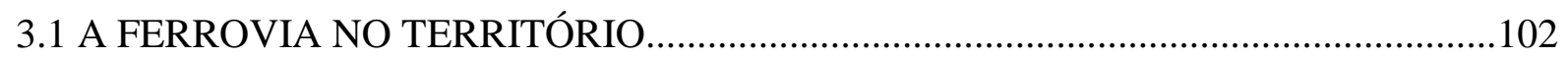

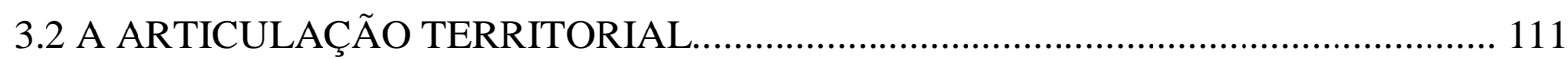

3.3 O ENTROCAMENTO: CONTRIBUIÇÃO LOGÍSTICA.................................................118

4 A FERROVIA NO DESENVOLVIMENTO BRASILEIRO.......................................... 134

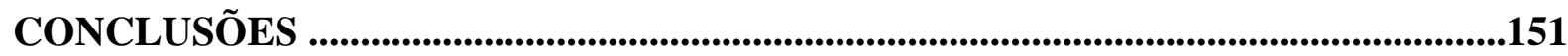

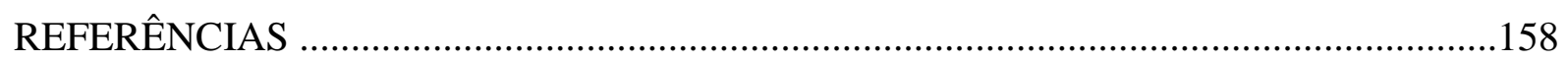

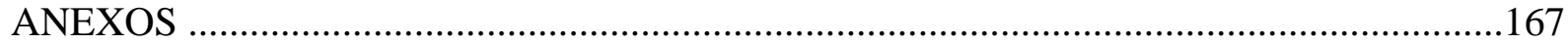


Universidade de Brasília

Instituto de Ciências Humanas

Departamento de Geografia

Programa de Pós-Graduação em Geografia

\section{LISTA DE QUADROS}

QUADRO 1 - Cronologia do Processo de Desestatização da RFFSA..........................59

QUADRO 2 - Transporte ferroviário de farelo de soja - Estações de origem por UF (2012)

QUADRO 3 - Interesses dos agentes do setor ferroviário no Brasil............................145 
Universidade de Brasília

Instituto de Ciências Humanas

Departamento de Geografia

Programa de Pós-Graduação em Geografia

\section{LISTA DE TABELAS}

TABELA 1 - População residente, segundo as unidades da federação - 1991/ 2000/ 2010 108

TABELA 2 - Matriz de transporte de cargas em geral e de produtos agrícolas no Brasil 139

TABELA 3 - Densidade rodovias por países 140

TABELA 4 - Densidade de transporte por grandes regiões 142 
Universidade de Brasília

Instituto de Ciências Humanas

Departamento de Geografia

Programa de Pós-Graduação em Geografia

\section{LISTA DE GRÁFICOS}

GRÁFICO 1 - Construção de estradas de ferro no Brasil entre 1881 e 1888 .38

GRÁFICO 2 - Evolução do Transporte de Cargas no Brasil entre 1970 e 2010...........61

GRÁFICO 3 - Evolução do Transporte de Passageiros no Brasil entre 1970 e 2010...62

GRÁFICO 4 - Saldo Migratório - 2004 / 2009 (mil hab.) 109

GRÁFICO 5 - População urbana e rural - Goiás - 1991/ 2000/ 2010 .109

GRÁFICO 6 - Distribuição do Transporte no Brasil em comparação com outros países .138

GRÁFICO 7 - Densidade de Rodovias e Ferrovias por UF no Brasil. .141 
Universidade de Brasília

Instituto de Ciências Humanas

Departamento de Geografia

Programa de Pós-Graduação em Geografia

\section{LISTA DE FIGURAS}

FIGURA 1 - Forma e posicionamento do Brasil dentro da América do Sul.................13

FIGURA 2 - Brasil à luz das Doutrinas Mahan - Mackinder - Seversky.....................14

FIGURA 3 - Geoestratégia da Amazônia....................................................................17

FIGURA 4 - Manobra de Integração do Território Brasileiro........................................20

FIGURA 5 - Áreas Geopolíticas do Território Brasileiro.................................................23

FIGURA 6 - Esboço de localização dos principais núcleos de povoamento e cidades do Brasil em 1750

FIGURA 7 - Os caminhos de ontem (estradas reais) e hoje (rodovias e ferrovias) que ligam Goiás e Tocantins aos portos litorâneos.

FIGURA 8 - Guia de Pacobaíba - a primeira estação ferroviária do Brasil .................31

FIGURA 9 - Integração Multimodal da Ferrovia com a Hidrovia na E.F. Mauá..........32

FIGURA 10 - Mapa Histórico com a Localização e o Traçado da Estrada de Ferro Mauá, ao fundo da Guanabara.

FIGURA 11 - Ferrovias no Brasil em 1870..............................................................

FIGURA 12 - Ferrovias no Brasil em 1890..............................................................

FIGURA 13 - Ferrovias no Brasil em 1910..........................................................

FIGURA 14 - Ferrovias no Brasil em 1930 ...............................................................44

FIGURA 15 - Ferrovias no Brasil em 1954........................................................... 47

FIGURA 16 - Ferrovias no Brasil em 1974 e Divisão Regional da RFFSA.................49 
FIGURA 17 - Superintendências Regionais da RFFSA no Brasil em 1984.

FIGURA 18 - Superintendências Regionais da RFFSA no Brasil em 1991.................53

FIGURA 19 - Ferrovia Paulista S/A - FEPASA 1977.........................................56

FIGURA 20 - Principais Ferrovias Brasileiras após a Privatização...........................60

FIGURA 21 - Locomotiva $n^{\circ}$ 403, tipo "Mallet", pertencente à Estrada de Ferro Goiás. .66

FIGURA 22 - Estrada de Ferro Goiás em 1927 .67

FIGURA 23 - Estrada de Ferro Goiás e suas Principais Articulações em 1970...........71

FIGURA 24 - Diagrama Unifilar da Ferrovia Centro Atlântica - FCA......................74

FIGURA 25 - Expansão da Frentes Pioneiras no Século XX em Goiás.......................76

FIGURA 26 - Viação Férrea do Centro.................................................................. 78

FIGURA 27 - Ferrovias na Região Centro Oeste em 2014...................................80

FIGURA 28 - Expansão das Frentes Pioneiras no Século XX em Tocantins, Goiás, Distrito Federal e Triângulo Mineiro. .88

FIGURA 29 - Trecho Goiano da Ferrovia Norte Sul. 103

FIGURA 30 - Ferrovias, Pátios de Embarque e Desembarque e Distritos Industriais em Goiás em 2013. 105

FIGURA 31 - Diagrama Unifilar da Ferrovia Norte Sul - FNS 107

FIGURA 32 - Eixos logísticos anteriores a Ferrovia Norte Sul e o surgimento de cidades em Goiás e Tocantins

FIGURA 33 - Malha Ferroviária do Brasil e os "Nós" de conexões das redes regionais

FIGURA 34 - Túnel da Ferrovia Norte Sul em Anápolis - GO.

FIGURA 35 - Fatores de urbanização vinculados às Ferrovias e Rodovias 120 
FIGURA 36 - Ferrovias VALEC no Brasil em 2013_...............................................122

FIGURA 37 - O Entroncamento Logístico Ferroviário Nacional e suas articulações

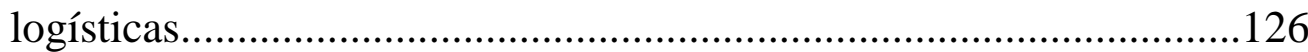


Universidade de Brasília

Instituto de Ciências Humanas

Departamento de Geografia

Programa de Pós-Graduação em Geografia

\section{LISTA DE ABREVIATURAS, SIGLAS E SÍMBOLOS}

Abiove - Associação Brasileira das Indústrias de Óleos Vegetais

ALL - América Latina Logística

ANTF - Associação Nacional dos Transportadores Ferroviários

ANTT - Agência Nacional de Transportes Terrestres

ANUT - Associação Nacional dos Usuários de Transporte de Carga

BNDES - Banco Nacional de Desenvolvimento Econômico e Social

BTU - British Temperatura Unity, Unidade Inglesa de Temperatura

CAD - Critério de Avaliação de Desempenho

CFN - Companhia Ferroviária do Nordeste

CIDE - Contribuição de Intervenção no Domínio Econômico

CNT - Confederação Nacional dos Transportes

CSN - Companhia Siderúrgica Nacional

CVDR - Companhia Vale do Rio Doce

DNIT - Departamento Nacional de Infra-Estrutura de Transportes

EFC - Estrada de Ferro Carajás

EFVM - Estrada de Ferro Vitória Minas

Embrapa - Empresa Brasileira de Pesquisas Agropecuárias

EMBRAER - Empresa Brasileira de Aeronáutica S/A

FCA - Ferrovia Centro Atlântica

FDNE - Fundo de Desenvolvimento do Nordeste

Fepasa - Ferrovia Paulista S.A.

Ferroban - Ferrovias Bandeirantes

Ferroeste - Estrada de Ferro Paraná Oeste

Ferropar - Ferrovia Paraná S.A 
FTC - Ferrovia Tereza Cristina

Geipot - Empresa Brasileira de Planejamento de Transportes

IBGE - Instituto Brasileiro de Geografia e Estatística

Incra - Instituto Nacional de Colonização e Reforma Agrária

Ipea - Instituto de Pesquisa Econômica Aplicada

Inesc - Instituto de Estudos Socioeconômicos

Novoeste - Ferrovia Novoeste S.A.

OMC - Organização Mundial do Comércio

OTM - Operador de Transporte Multimodal

PIB - Produto Interno Bruto

PND - Programa Nacional de Desestatização

PPP - Parceria Público-Privada

Prodecer - Programa de Cooperação Nipo-Brasileira para o desenvolvimento do Cerrado RFFSA - Rede Ferroviária Federal S.A.

Secex - Secretaria de Comércio Exterior

TEU - Twenty equivalente unit, unidade equivalente a um contêiner de 20 pés

TKU - Tonelada por quilômetro útil

TU - Tonelada útil tracionada 


\section{INTRODUÇÃO}

Ano após anos nos deparamos com uma contradição quase inexplicável em relação ao nosso país. O Brasil possui um enorme território, riquezas naturais praticamente inestimáveis, um grande efetivo populacional, um grande litoral que favorece o comércio e as relações internacionais, possui fronteira terrestre com vários países da América do Sul, não é acometido por cataclismos como terremotos violentos, tsunamis, furacões, nevascas e mesmo assim, não conseguimos alçar ao nível de outras nações do mundo que são menos favorecidas.

Várias razões são elencadas para tentar justificar esta situação, como a ambiguidade histórica do nosso desenvolvimento que não prezou pela melhoria das condições da vida da sociedade, mas apenas de uma pequena e seleta classe social. Ressalta-se que a nossa própria nação tem antagonismos históricos profundos, o que é bem marcado pela data da libertação dos africanos escravizados em 1888, e a criação do Serviço de Proteção Indígena em 1910, permitindo aqui refletir sobre a recente igualdade jurídica do nosso país. Ou seja, temos pouco mais de 120 anos de igualdade social, o que expressa os desafios da consolidação da nossa modernização brasileira em todos os sentidos.

De repente você pode se perguntar sobre a relação entre ferrovias e igualdade jurídica, independente de raça, gênero ou credo. Todavia, ao discutir sobre o que é modernizar, evoluir, avançar enquanto seres humanos, elementos que deveriam ser considerados como umas das maiores essências da pesquisa científica, percebe-se que nos perdemos nas fragmentações do saber em função de interesses hegemônicos, devidos sobretudo às lutas de classes e o domínio do meio material.

Como não há espaço e nem é propósito nesta tese analisar exaustivamente todos os assuntos elencados, aqui fazemos um recorte sobre a atual situação do desenvolvimento do nosso país, a partir da sua "modernização" recente, com ênfase na economia e suas limitações ocasionadas pela falta de adequada infraestrutura logística. Como o Brasil é um país nascido de uma colônia portuguesa, que precisar dar lucros a Coroa e aos "investidores", o planejamento logístico foi estabelecido a partir da necessidade de levar as mercadorias e minérios, via navios até Portugal.

Isso é imperativo, pois não houve, a priori, uma preocupação em disponibilizar infraestruturas adequadas para modernizar o Brasil, e sim em fazer com que tais elementos fixos - se transformassem em artérias que deveriam levar os recursos - fluxos - aos cofres das elites europeias. Então consegue-se visualizar o crescimento da infraestrutura logística 
brasileira "nascendo" no litoral e aos poucos adentrando o interior do continente, guiados pela busca das riquezas naturais, mesmo que desprezando as riquezas humanas.

A "proa" econômica que direcionou a ocupação e a exploração dos recursos naturais que ocorreram em parte das atuais regiões Nordeste e Sudeste do Brasil, em um primeiro momento pela extração do pau-brasil e das plantations de cana, mais tarde guinaram para as minas do interior do território. Pernambuco, Bahia, Rio de Janeiro e São Paulo "ancoraram" os pontos iniciais da rede logística brasileira e a partir delas os arcos e nós foram paulatinamente sendo tecidos no arranjo da exploração comercial do território.

Até o século XVII, as limitações deste arranjo estavam definidas no Meridiano de Tordesilhas, estabelecido a partir de 370 léguas ao oeste do arquipélago das Ilhas de Cabo Verde, no litoral africano. Curiosamente um marco muito ousado para a tecnologia da época, mas que retrata a realidade da globalização econômica que se formava via transportes marítimos. Desde então, a definição de potências mundiais, ou de nações desenvolvidas passam a serem confundidas com evolução econômica, sobretudo no aspecto da acumulação de riquezas materiais. E para que isso fosse possível, era preciso dominar as tecnologias que possibilitassem uma eficiente logística de transportes.

No mundo contemporâneo isso é uma realidade marcante. As nações que atualmente são consideradas como potências, são exatamente aquelas que possuem infraestruturas logísticas adequadas ao seu perfil, seja quanto ao tamanho territorial e populacional, e também quanto à lógica hegemônica da sua concepção, seja ela gerar recursos materiais, ou qualidade de vida, ou ainda ambos.

No caso brasileiro, o foco principal foi a geração de riquezas, e secundariamente a qualidade de vida. Basta lembrarmos que a busca de riquezas materiais e a defesa delas justificou o avanço do domínio português, com consequente aumento do território brasileiro além Tordesilhas. Isso foi materializado através de união de duas nações que tinham rivalidades antigas, mas que se uniram pelos interesses econômicos. Portugal e Espanha estabeleceram a União Ibérica entre 1580 e 1640, e passaram a dividir a tarefa de manter a América em suas posses, conforme a divisão e doação feita pelo papa na Bula Intercoetera, em 1492, oito anos antes do "descobrimento".

Como as limitações espanholas restringiam sua capacidade operacional de explorar e defender tamanho território "recebido" pelo papa, sobretudo devido à limitação imposta pela Cordilheira dos Andes na costa do Pacífico, e a grande extensão norte sul das suas posses, houve por bem contar com a estrutura portuguesa que estava concentrada no litoral Atlântico. 
Isso foi possível em função da existência de diversos rios que estavam sobre controle português, os quais eram verdadeiras portas de entradas e "estradas prontas" para o acesso ao interior do continente sul americano, principalmente ao considerar que os transportes navais eram os mais eficientes da época.

O resultado de toda essa estratégia de defesa do continente, diante das invasões francesas, inglesas e holandesas, foi a ocupação e construção de fortificações militares e portos que visavam o controle das bacias hidrográficas. Como na época era impossível ter efetivos militares em todo o território, poderia se controlar e assegurar sua posse através da instalação estratégica de fortes que controlassem a foz dos rios navegáveis, assim como suas principais intersecções. Estava estabelecida a primeira estratégia geopolítica de defesa continental, baseada no controle da circulação logística, visando a garantia da posse dos recursos naturais.

Por isso, ao olhar o próprio mapa do Brasil, fica evidente a relação entre a forma do território e a configuração geográfica das bacias hidrográficas, que são mais "largas" no sentido oeste - leste na parte norte do país, por causa do Rio Amazonas e seus afluentes, e mais "longilínea" no sentido norte - sul, na porção sul, por causa da bacia do Prata e seus afluentes. Ou seja, a confluência da logística de transporte com a hidrografia sul americana contribuiu para a definição dos limites territoriais do Brasil.

A logística dos transportes foi responsável por estabelecer outras etapas da ocupação do território, principalmente a partir do ciclo da mineração, quanto as estradas reais foram abertas pelos bandeirantes e exploradores, a fim de acessar as jazidas existentes no interior do continente. Como na época os meios de transportes terrestres eram limitados pelos acidentes geográficos, e restritos quanto à capacidade de carga e velocidade, vários pontos de apoio às comitivas, caravanas e expedições foram surgindo ao longo dessas vias, dando origem às primeiras cidades no interior do Brasil.

Desde então a busca pelos recursos materiais existentes no interior do território possibilitou a construção de uma rústica rede de estradas terrestres que permitiram a paulatina ocupação do território. Com a evolução no meio técnico e científico na área dos transportes terrestres, materializado nas ferrovias, ocorreu uma revolução logística em todo o mundo. A capacidade de carga e a velocidade do novo modal permitiu grande incremento na economia, e consequentemente nas transformações nos territórios mundo afora.

No Brasil não foi diferente, especialmente após a sua libertação de Portugal ocorrida em 1822. Houve uma busca por um desenvolvimento econômico do país, que agora aprendia a 
escolher seus destinos, o que exigia a integração das áreas distantes do litoral. Os grandes atrativos continuaram sendo os recursos naturais, sejam os minérios, e também as terras férteis, próprias para a produção agrícola e pecuária. Ressalta-se que no século XIX, o principal parceiro comercial do Brasil era a Inglaterra, e de lá vieram os primeiros trilhos e as primeiras locomotivas. Embora a primeira ferrovia tenha sido construída no Rio de Janeiro em 1854 pelo Barão de Mauá, foi em São Paulo que o transporte ferroviário encontrou solos férteis para estender seus trilhos, sobretudo nas áreas de cultivo da monocultura cafeeira, destinada à exportação.

A sinergia entre interesses econômicos estrangeiros e a logística ferroviária representou a maior força de ocupação do interior brasileiro no século XIX. O Estado de Goiás que havia nascido após a expansão territorial propiciada pelo fim da União Ibérica em 1640, mas regulamentada apenas entre 1713 com o Tratado de Utrecht, e consolidado em 1750 pelo Tratado de Madri, sobre a égide econômica da mineração, agora passará por mudanças em função dos trilhos paulistas que chegam nas franjas do seu território.

Ao adentrar o solo goiano no início do século XX, as ferrovias aceleram o processo de ocupação do estado, modificam a estrutura econômica, favorecem o fluxo migratório, e integram de forma mais intensa o Estado ao cenário econômico nacional e internacional. A circulação favorecida pelas ferrovias no período após a Primeira Guerra Mundial, ainda permitiu a implantação de políticas de ocupação e integração do território, como a Marcha para o Oeste. Foi pelas ferrovias que boa parte das populações que estavam no litoral paulatinamente avançaram sobre o território, marcando o avanço das frentes de expansão e frentes pioneiras.

A integração do território ao circuito capitalista da economia, marcada principalmente pela agregação de valor às terras estimularam o surgimento de várias cidades e a efetiva ocupação do chamado sertão, este entendido enquanto oposição ao litoral. Novas capitais foram criadas, como Goiânia na década de 1930 e Brasília na década de 1950, sendo esta inaugurada no início da década de 1960. Tais cidades foram mais do que novas infraestruturas político administrativas. Elas representaram a modernização esperada com a integração nacional, e por isso, lograram êxito na atração de efetivos populacionais, necessários ao desenvolvimento do interior.

Brasília marca esse processo de uma forma diferente, pois a partir dela, há uma clara mudança no foco no modelo de transportes terrestres do modal ferroviário para o modal rodoviário, principalmente por causa das várias ferrovias que ligam a nova capital a todas as 
partes do país. Há quem defenda que isso ocorreu pela substituição da influência econômica da Inglaterra, que até então era a grande potência mundial, pela ideologia da nova potência que após a Segunda Guerra Mundial será os Estados Unidos da América, baseada no "rodoviarismo". Constata-se que isso é uma equivoco, pois nos Estados Unidos haverá investimentos maciços tanto em rodovias como também em ferrovias, enquanto que no Brasil, as ferrovias foram praticamente abandonadas, relegadas paulatinamente ao segundo plano, devido a clara priorização das rodovias.

A crise no sistema ferroviário brasileiro ocorreu por falta de investimentos, e o governo assume o controle do modal, com a privatização feita em nível federal através da criação da Rede Ferroviária Federal S/A - RFFSA, e em nível estadual, particularmente São Paulo, com a criação das Ferrovias Paulista - FEPASA. Ao analisar a origem e evolução das ferrovias brasileiras, percebe-se que elas surgem no cenário do liberalismo econômico, patrocinadas principalmente pelos capitais privados. Com as crises econômicas advindas da Primeira Guerra Mundial, mais tarde, da Quebra da Bolsa de 1929 e posteriormente, da Segunda Guerra Mundial, o liberalismo econômico é substituído pelo keynesianismo.

Tal política também é conhecida como Welfare State ou Estado do Bem Estar Social, onde o Estado passa a assumir as funções de prover as necessidades dos cidadãos, inclusive nos transportes. Foi neste contexto histórico e econômico que as ferrovias brasileiras foram privatizadas. Curiosamente, décadas após a reconstrução das nações por causa da Segunda Guerra, voltou-se a defender o liberalismo, agora chamado de neoliberalismo, política defendida pelas potencias hegemônicas ocidentais a partir do final dos anos 1970 e ao longo das décadas de 1980 e 1990.

Com o fim da Guerra Fria, marcada pela queda do Muro de Berlim em 1989 e o fim da URSS em 1991, o neoliberalismo é implantado em praticamente todo o mundo ocidental. O resultado disso na logística mundial é o retorno do controle privado nas infraestruturas, e no caso brasileiro, houve a privatização de toda a rede férrea brasileira, durante a década de 1990. A consequência foi o surgimento de várias empresas ferroviárias que passaram a controlar esse modal de transporte no país. Como o modelo privado precisa ser superavitário, vários ramais antieconômicos foram desativados, inclusive com o fim do transporte de passageiros, que doravante ficou restrito aos trens urbanos e a poucas linhas turísticas.

Após o início da primeira década do século XXI é que novos investimentos passaram a ser feitos nos transportes ferroviários, diante da necessidade do país estabelecer estratégias competitivas no mercado internacional, a partir de uma eficiente rede logística que favoreça a 
diminuição dos custos de produção. Enfim, no neoliberalismo deve prevalecer a livre concorrência, de modo que a disponibilidade de transportes mais baratos e eficientes passam a ser fundamentais para manutenção do crescimento econômico. No Brasil novas ferrovias foram criadas para atender sobretudo as demandas por transportes de longas de distâncias e com alto volume agregado de cargas, como minérios e commodities. Para gerenciar as novas ferrovias o governo federal criou a estatal VALEC.

O novo arranjo das ferrovias VALEC, no território brasileiro beneficiaram de modo muito especial o estado de Goiás, que passa a ter no seu solo, a interseção das principais vias nacionais, transformando-o no grande entroncamento logístico ferroviário nacional. Com base nesta análise desenvolvemos e defendemos a tese de que Goiás é o novo entroncamento logístico da rede ferroviária brasileira, conectando as malhas das regiões Norte e Nordeste com as do Centro Oeste, Sudeste e Sul, exercendo doravante fundamental papel de articulação na logística nacional. O principal argumento é a necessidade de fornecimento de fretes mais baratos para melhorar a competitividade da economia nacional diante do atual cenário mercadológico internacional.

Ao defender a tese de que Goiás é o novo entroncamento logístico ferroviário nacional, resultante da construção das novas ferrovias VALEC pelo Brasil, pode-se inferir as diversas possibilidades de rotas e integrações modais que culminarão com a queda do preço do frete, sobretudo de mercadorias com alto volume de carga e baixo valor agregado. A partir da categoria território de Santos (2002), que o considera enquanto espaço apropriado e utilizado, sobretudo pela economia, discute se a formação da rede ferroviária e suas modificações no país.

Assim, baseado nos conceitos geopolíticos, com ênfase na necessidade da circulação, de mercadorias e pessoas, estabeleceu-se a situação brasileira no cenário internacional, quanto a continentalidade e maritimidade. Em seguida vinculou-se as potencialidades brasileiras e o seu papel na divisão internacional do trabalho, seus principais parceiros comerciais, como chegar até eles, qual o custo disso, enfatizando potencialidades e limitações.

Posteriormente discutiu-se o papel das redes logísticas brasileiras neste processo, com ênfase no transporte ferroviário. Para isso, analisou-se a origem e evolução das ferrovias; suas principais localizações e papeis; os principais produtos transportados ao longo da história, de acordo com cada região; as demandas internacionais; os estatizações e privatizações; tudo isso a fim de entender a atual formatação ferroviária brasileira e suas relações com os portos, rodovias e principais centros industriais, comerciais e agropecuários. 
Feita a análise de toda essa base conceitual da geopolítica e das redes ferroviárias sobre o Brasil, estabeleceu-se o recorte espacial em Goiás, analisando sua origem e evolução econômica, a chegada das ferrovias em Goiás, a política da Marcha para o Oeste, a criação de Goiânia, posteriormente Brasília-DF e Palmas - TO, o avanço das frentes pioneiras e o resultado de todas estas transformações no território goiano.

Por fim, cruza-se os dados sobre a geopolítica nacional e as redes logísticas para compreender o papel de Goiás na Geopolítica Nacional com ênfase na capacidade de circulação do território, cruzando o posicionamento do Estado e a infraestrutura ferroviária brasileira, sobretudo com destaque para as novas ferrovias, como a Norte Sul, que foi ligada à antiga Mogiana, hoje Ferrovia Centro Atlântica - FCA, que por sua vez é parte do grupo VLI.

Para isso, baseou-se em dados estatísticos da ANTT, ANTF, MT, MA, DNER, IBGE, GEIPOT, RFFSA, FEPASA, FCA, GRUPO VLI, VALEC, SEGPLAN - GO, além dos autores elencados na revisão teórica, com destaque para SANTOS (território, economia, fronts), DIAS (redes, circulação), SILVA, BECKER, STEINBERGER (geopolítica, economia, poder), FURTADO (desenvolvimento, economia nacional), MONBEIG, MARTINS, WAIBEL (fronteiras, frentes pioneiras e frentes de expansão), VENKOVSKY, SANTOS, CASTRO (transportes), NETO, GOMES, SALES, ARRAIS, BARREIRA, TEIXEIRA (Goiás), além dos demais autores constantes das bibliografias.

O objetivo principal foi compreender a apropriação territorial brasileira, a partir do viés econômico, fundamentado na análise geopolítica, com foco na relação entre a circulação via transportes ferroviários, a integração nacional e a competitividade logística. Neste sentido, estudou-se as ferrovias brasileiras, relacionando-as ao contexto globalizado contemporâneo e a necessidade do melhorar a competitividade do país a partir de uma rede de transportes eficientes e que possibilitem preços mais baratos.

As hipóteses inicialmente estabelecidas indicavam que a expansão das ferrovias em território goiano seria fruto do próprio avanço da fronteira econômica, entendida enquanto frentes pioneiras, dando continuidade ou complementaridade à produção cafeeira paulista. Outra hipótese foi a de que a construção das novas ferrovias brasileiras, cujas conexões principais estão localizadas em Goiás, faria deste Estado um grande entroncamento logístico nacional, principalmente em virtude do tamanho e da importância econômica de tais vias. A última hipótese é que o Brasil Central poderá se beneficiar a partir da presença dessas ferrovias, tanto pelas vantagens propiciadas pela articulação ferroviária, como a instalação de 
novas empresas em seus distritos industriais, e também, pelo estimulo direito ao aumento da produção agropecuária e mineral.

A justificativa da pesquisa fundamenta-se na relação entre a competitividade econômica internacional e o aprimoramento logístico, baseado sobretudo na lógica da diminuição dos preços das mercadorias, para que se consiga vendê-las aos consumidores, tanto internos quanto externos. Dentre os fatores que são responsáveis por uma adequada competitividade, destaca-se a eficiência nos transportes, principalmente para o Brasil que é um país de dimensões continentais, e grande produtor de mercadorias de baixo valor agregado, como commodities e minérios, os quais necessitam de alto volume de transporte. Tais detalhes fazem com que o valor do frete seja responsável por boa parte do preço final das principais mercadorias, e portanto, tenha grande relevância para a economia do país.

Outro detalhe da justificativa diz respeito ao papel das ferrovias para a integração econômica dos estados brasileiros situados no interior do país. Além de possibilitar o crescimento da produção na medida em que a circulação é garantida, os fluxos de capitais recebidos por estes estados cooperam para o surgimento e a expansão de novos negócios. Os impostos gerados nestes estados contribuem também para o incremento em infraestrutura e serviços destinados a atender as populações locais, diminuindo a dependência em relação aos outros entes federativos. 


\section{A IMPLANTAÇÃO DA REDE FERROVIÁRIA E A FORMAÇÃo DO TERRITÓRIO NACIONAL}

O propósito deste capítulo é mostrar o processo de implantação das ferrovias no Brasil relacionada a evolução econômica nacional e a sua participação no cenário produtivo mundial, o que resultou em uma complexa rede logística. A paulatina modernização nos meios de transportes, especialmente os terrestres, permitiu a expansão das áreas produtivas em todo o mundo. Todavia, no Brasil, o início dos transportes de grande envergadura começa no litoral. O Brasil nasceu na ótica econômica internacional, segundo interesses geopolíticos mundiais, uma vez que, como colônia de Portugal, necessitava de pontos de embarque e desembarque de mercadorias e pessoas, visando o atendimento dos transportes, que à época eram predominantemente navais.

Além disso, a necessidade de controle das terras recém descobertas da América, no final do século XV e início do XVI, diante dos interesses das potências europeias, configurou uma política territorial de ocupação e consolidação da posse mediante a exploração dos recursos. Mais tarde vários conflitos ocorreram na área que veio a ser o solo brasileiro, e neste sentido, discutiremos o papel da logística na geopolítica sul-americana, para a compreensão da atual configuração dos limites brasileiros, com ênfase na relação entre Portugal e Espanha.

Doravante, o crescimento da ocupação ocorrerá principal pelos rios que adentram o território e pelas estradas reais que foram abertas pelos colonizadores. Até o início do século XIX, os modais logísticos do Brasil, continuaram os mesmos, até que a partir da independência e a busca de novos modelos econômicos, agora influenciados sobretudo pela Inglaterra, as ferrovias passar a ser consideradas como alternativa para romper as grandes distâncias territoriais. Assim chegam ao Brasil a partir de 1854, e passam a contribuir para a interiorização da apropriação do território, inicialmente mediante a expansão da produção primeiramente do café, e posteriormente, de outros produtos, permitindo um considerável incremento econômico, aliada à paulatina integração do território.

A formação da rede ferroviária brasileira iniciou-se a partir do litoral, repetindo o caminho dos colonizadores europeus e adentra o território alcançando regiões cada vez mais distantes. Com isso o território passa por um processo seletivo de dinamização espacial baseada na modernização econômica, uma vez que por essa rede "a redução do lapso de tempo permitiu instalar uma ponte entre lugares distantes" (DIAS, 2000: 141). A velocidade e a intensidade das transformações no território só foram possíveis quando "as trilhas e os 
caminhos foram progressivamente substituídos por estradas de ferro no transporte de bens e mercadorias (IDEM: 142).

Todo esse processo foi comandado pelas elites brasileiras em parceria com as elites econômicas das nações amigas. Segundo Dias (IBIDEM) "a habilidade das classes burguesas no século XIX em influenciar a organização do espaço via investimentos em infraestrutura era, na verdade mundial. No Brasil, a participação dos plantadores de café nas sociedades de estradas de ferro demonstra o poder social conquistado". Tal fato demonstra o vínculo do capital privado no direcionamento dos rumos do país, enquanto que o setor público restringese a regulamentação política, jurídica e tributária do sistema. Ou seja, as elites econômicas é que indicam os caminhos a serem trilhados pelo estado, seja no aspecto intelectual, social e também material. Por isso Dias (IBIDEM) afirma, mais especificamente: "a burguesia paulista que, decidindo sobre configuração espacial da rede ferroviária e assim, sobre a circulação, comandava de uma forma quase completa o sistema produtivo".

A rede ferroviária brasileira é composta por nós e arcos, onde os nós são compostos por centros comerciais e ou econômicos, como as principais capitais e portos das regiões Sudeste, Nordeste e Sul, e os arcos são as linhas férreas que passam a conectar cidades e regiões produtoras distantes do litoral. Os conceitos de nós e arcos aqui citados são baseados em Souza (2000: 93) que explica da seguinte forma: “a rede (...) é, em termos abstratos e para efeito de representação gráfica, um conjunto de nós - conectados entre si por segmentos arcos - que correspondem aos fluxos que os interligam, "costuram" os nós - fluxos de bens, pessoas ou informações”. Mais especificamente sobre os arcos, o citado autor complementa "os arcos podem indicar elementos infra estruturais presentes no substrato espacial - p. ex., estradas que viabilizam o deslocamento dos fluxos" (IBIDEM).

As ferrovias favorecem, portanto, a formação de um território em rede, ou descontínuo, que passa a conectar vários territórios contínuos, como aqueles representados pelas plantações de café. Entre eles existem áreas de serras, rios e matas, que dada a sua configuração geográfica não foram considerados inicialmente apropriados para a produção, mas que precisam ser atravessados pelas ferrovias para levar os fluxos produtivos até os locais de consumo e ou comercialização. Nestes locais configuram-se centros regionais e nacionais da economia, que passam a comandar a apropriação de regiões cada vez mais distantes do território, no esforço de expansão da produção, via aumento das áreas produtoras.

Por isso, Dias (2000: 145) afirma mais tarde que "o projeto comum era o projeto de integração territorial, integração de mercados regionais, pela quebra de barreiras físicas, 
obstáculos à circulação de mercadorias, de matérias primas, mas também de capitais". Assim, a modernização do meio técnico cientifico e informacional, manifesto nas ferrovias possibilitou o que Dias (IDEM: 147) intitulou de "densificação das redes", cujo objetivos principais eram dois: circular e comunicar. Por isso, as redes possibilitam movimentos contínuos e inacabados, como afirma Raffestin (1980: 185) "a rede faz e desfaz as prisões do espaço tornado território: tanto libera como aprisiona. É por que ela é "instrumento" por excelência, do poder", especialmente o econômico.

Para compreender as transformações no território brasileiro, é preciso analisar a origem e a evolução das ferrovias no país, pois foram ao mesmo tempo sujeito e objeto deste processo. Sujeito uma vez que permitiram tais modificações, e objeto pois, mais tarde viram se reféns da substituição pelas rodovias, após décadas de contribuições para a economia nacional. Para isso, serão analisados nos tópicos a seguir, como esse processo ocorreu ao longo da história, segundo a ótica geopolítica brasileira. Em seguida será discutido quais os elementos geográficos, políticos e tecnológicos que contribuíram para o entendimento da atual configuração da malha ferroviária brasileira. Por fim, busca-se o entendimento do papel do estado, das elites nacionais e do capital privado internacional, no controle ora público e ora privado das redes férreas.

\subsection{O CONTEXTO GEOPOLÍTICO BRASILEIRO E SUAS REDES LOGÍSTICAS}

Neste tópico, serão enfocados os principais dados da geopolítica brasileira, a circulação no território e a estratégia de desenvolvimento nacional no contexto. No caso do Brasil, este é posicionado no "Crescente Externo" defesa em conjunto com os EUA - o Continente Americano, privilegiando sua circulação.

Segundo as concepções e hipóteses geopolíticas mundiais, vários elementos do espaço são considerados no momento do planejamento das estratégias a serem executadas. Silva explica que,

A análise do espaço diz respeito principalmente à definição de uma geopolítica aplicada ao campo interno e visando à integração total e à valorização cada vez maior do território nacional, enquanto a estimativa da posição interessa, sobretudo a Geopolítica orientada para o exterior (...). Ora, tanto na posição como no espaço, influi decisivamente, como fácil é concluir, um fator capital - a circulação - pois

\footnotetext{
${ }^{1}$ Sobre este assunto ver BECKER, Bertha K. A geopolítica na virada do milênio: logística e desenvolvimento sustentável. (in) CASTRO, Iná Elias et al. Geografia: conceitos e temas. Rio de Janeiro: Bertrand Brasil, 1995.
} 
esta é que vincula os espaços políticos internos ou externos, que conquista, desperta e vitaliza o território, que canaliza as pressões e orienta as reações defensivas e que dá significação concreta à extensão, à forma, à situação (1981, p. 35).

Ou seja, entendendo o espaço brasileiro pode-se planejar melhor todas as ações ligadas a construção de um país com maior poder. O poder nacional pode ser aumentado de acordo com as infraestruturas de circulação instaladas no território, uma vez que permitem a otimização do emprego de seus recursos, e também, à coesão da estratégia nacional de desenvolvimento. Novamente evidencia-se o papel dos transportes para assegurar a circulação interna na nação, e neste cenário, destaca-se a importância das ferrovias. Lacoste analisa que:

\begin{abstract}
Afirmar que a geografia serve fundamentalmente para fazer a Guerra não significa somente que se trata de um saber indispensável àqueles que dirigem as operações militares. Não se trata unicamente de deslocar tropas e seus armamentos uma vez já desencadeada a guerra: trata-se também de prepará-la, tanto nas fronteiras como no interior, de escolher a localização das praças fortes e de construir várias linhas de defesa, de organizar as vias de circulação (1997: 29).
\end{abstract}

Com base na afirmação de Lacoste pode-se entender que o conhecimento do meio é fundamental para a definição do poder de uma nação. Assim, compreende-se melhor a capacidade de análise geopolítica da geografia, uma vez que esta é por excelência a ciência que discute a sociedade e o espaço. Por isso, a leitura geográfica do espaço do Brasil levanta outros elementos estratégicos para a elaboração de infraestruturas importantes para a integração nacional e a garantia do poder, como as vias de circulação, em especial as redes ferroviárias.

A análise do espaço possibilita, enfim, uma melhor compreensão dos efeitos das concepções geopolíticas mundiais para o Brasil, e também para o correto entendimento dos determinantes geográficos nas concepções geopolíticas nacionais. O Brasil possui 8.513.844 $\mathrm{Km}^{2}$ de área, sendo que no sentido Norte-Sul (Monte Roraima até o Arroio Chuí) - 4.307 km e no sentido Leste-Oeste (Serra da Contamana até a Ponta do Seixas) - 4.336 km (CASTRO, 1986). Observa-se ainda, que o Brasil é um país marítimo, possuindo $18 \%$ da extensão territorial em faixa de fronteira (250 km que acompanha o litoral), $42 \%$ se encontram entre $250 \mathrm{~km}$ e $1.000 \mathrm{~km}$, e os $40 \%$ restantes, encontram-se além de $1.000 \mathrm{~km}$ do litoral.

Tal dado evidencia que o país necessita de importantes vias de transportes e comunicações, uma vez que sua coesão territorial depende de sua integração. As estratégias geopolíticas tiveram que levar em conta estes elementos para a sua eficácia, caso contrário, o almejado poder nacional poderia ser comprometido pela falta de ligações entre todas as partes do Brasil. 
O Brasil é uma potência emergente (BECKER e EGLER, 1998), figurando entre os mais populosos do mundo, com outras três condições fundamentais: espaço, posição e matérias-primas, que dentro do conceito geopolítico global, lhe posiciona como nação satisfeita (CASTRO T., 1999). A figura 1 apresenta uma análise da forma e posicionamento do Brasil dentro do continente.

Figura 1: Forma e posicionamento do Brasil dentro da América do Sul.

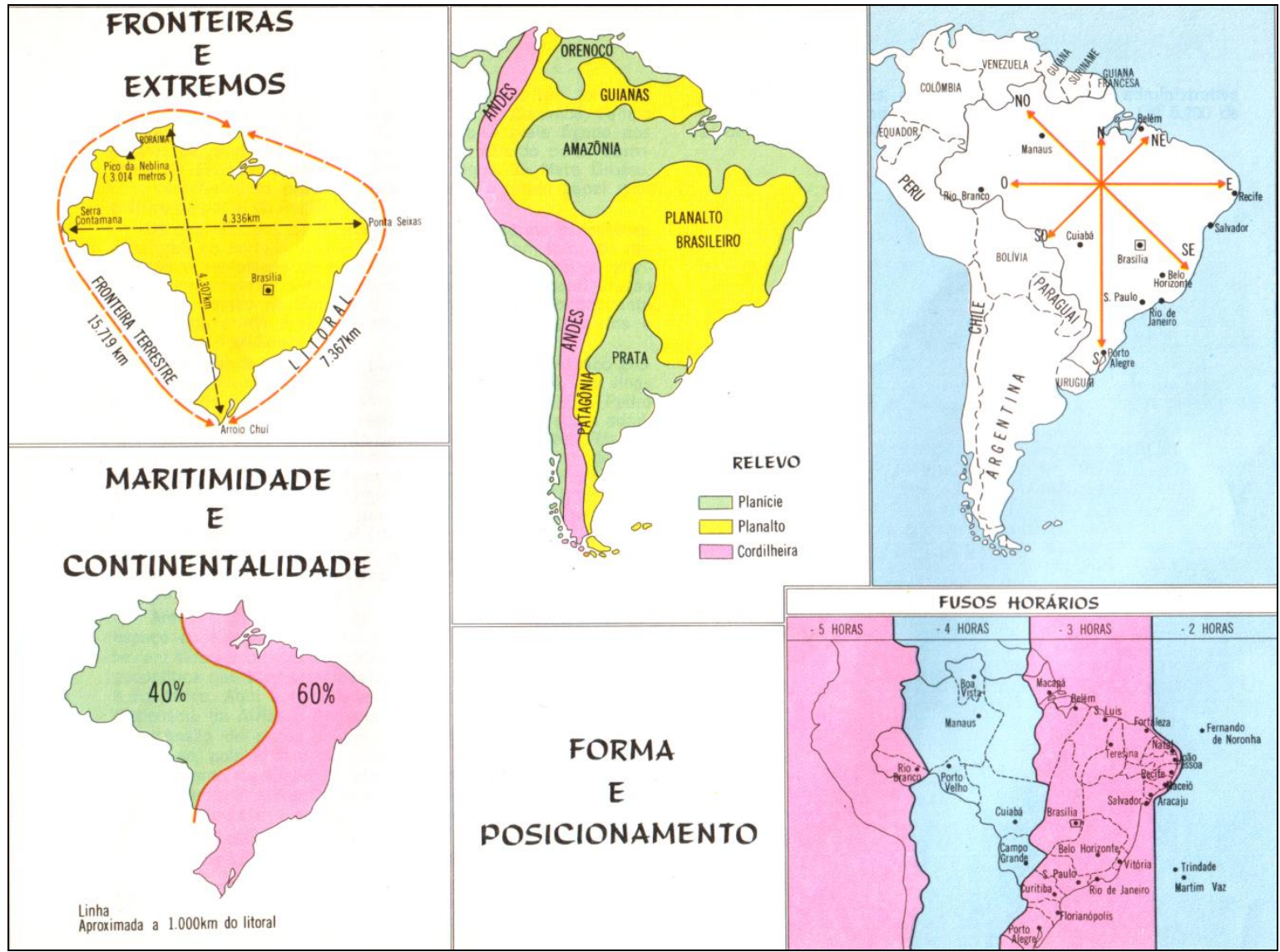

Fonte: CASTRO, 1986, p. 16.

Para uma análise do Brasil à luz da doutrina Mahan - Poder Marítimo - quatro fatores são considerados: primeiro, o posicionamento e a fisiopolítica; segundo, a extensão territorial; terceiro, o aspecto psicossocial, ou seja, a população e o caráter nacional; e quarto, a política de governo. Além de um excelente posicionamento que favorece a ação marítima, a configuração territorial brasileira favorece também o poder aéreo devido ao domínio no Atlântico Sul. Dada a extensão continental, destaca-se a importância de uma eficiente rede ferroviária nacional.

Castro (1986) propõe a junção da teoria do poder marítimo e da teoria do poder terrestre com o objetivo de melhor compreender e planejar a geopolítica brasileira, criando a doutrina 
Mahan Mackinder. A presente doutrina parte do poder terrestre para o domínio mundial com base no hemisfério norte, não prescindindo do Poder Marítimo envolvido pelo Crescente Insular Externo, que além do Caribe e América do Norte, abrange o Cone Sul e as suas zonas de projeção - a África do Sul e a Austrália. A autora acrescenta ainda, outra análise ao incorporar o poder aéreo junto ao poder marítimo e terrestre, concebendo a doutrina Mahan Mackinder - Seversky. Com base na figura dois, mais uma vez evidencia-se a importância da circulação Brasil em relação ao mundo.

Figura 2: Brasil à luz das Doutrinas Mahan - Mackinder - Seversky.

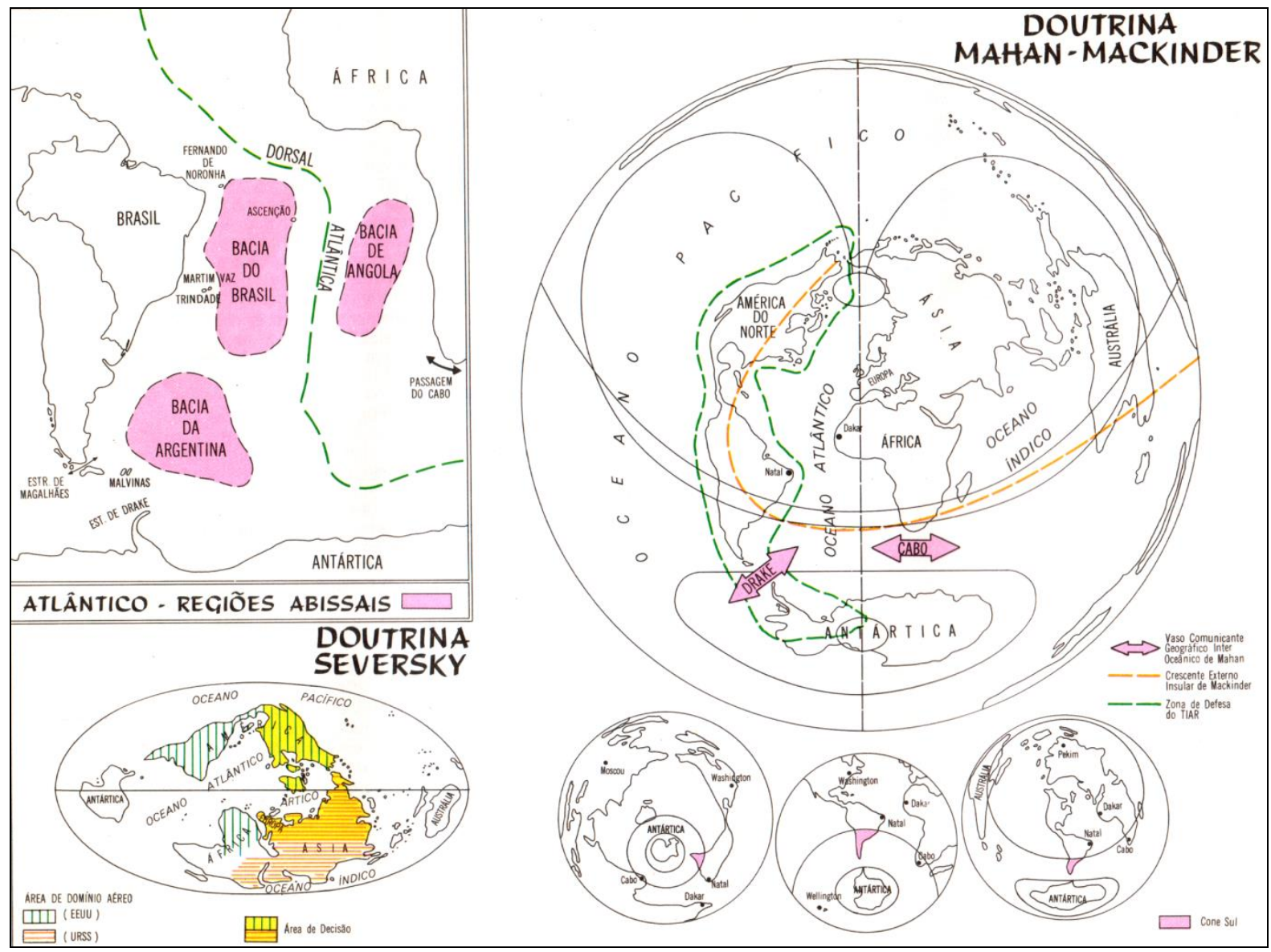

Fonte: Castro, 1986, p. 18.

Ela observa que à luz desta doutrina, o Brasil deve estar em condições de estabelecer a defesa de suas rotas marítimas e ter presença nos vasos comunicadores interoceânicos de "Drake" e do "Cabo". Já o poder aéreo deve estar preparado para uma nova realidade, pois através da aviação tática com maior alcance, há o risco de vulnerabilidade do espaço aéreo, comprometendo a segurança inclusive marítima. Esta realidade ficou comprovada com a sobreposição do alcance americano e russo provocando a criação da OTAN e o Pacto de Varsóvia. 
Dessa forma, o Brasil viveu todas as consequências da bipolarização mundial uma vez que integrou o bloco ocidental como país do continente americano. A proliferação de acordos no mundo e também no continente provocou a mudança da geopolítica brasileira. De acordo com Castro,

Tendo em vista a proliferação de acordos no continente, a geopolítica do Brasil começou a se fundamentar no "envolvimento", pela atração, ou "rimland" de Spykman. O grande trunfo brasileiro é o posicionamento em face do atlântico e ao nosso envolvimento direto nas grandes duas bacias hidrográficas (1986, p. 22).

As duas principais bacias hidrográficas brasileiras - Amazônica e Prata - foram extremamente importantes não só na transposição do meridiano do Tratado de Tordesilhas, mas também, na integração nacional e na estratégia geopolítica de envolvimento dos países da América do Sul. Com relação à geopolítica do Prata, sua importância é ressaltada por ser a $5^{\text {a }}$ maior do mundo ${ }^{2}$ totalizando $3.056 .000 \mathrm{~km}^{2}$, dos quais $1.400 .000 \mathrm{Km}^{2}$ é brasileira.

O sistema platino é constituído por três grandes eixos fluviais: os Rios Paraguai, Paraná e Uruguai. Todos deságuam no mesmo ponto do Oceano Atlântico. A perda da Província Cisplatina $^{3}$ fez com que o Estado brasileiro pouco a pouco estabelecesse estratégias para não ficar dependente exclusivamente da Foz do Prata como via de acesso e transporte de mercadorias dos Estados de Mato Grosso do Sul e Mato Grosso. Esta estratégia foi materializada pelos três corredores de exportação instalados, servidos de redes rodoviárias e ferroviárias, neutralizando a necessidade da Foz do Prata para o comércio. Entretanto, a Bacia do Prata ainda é uma importante via de integração nacional e continental. Os portos de Santos, Paranaguá e Rio Grande, todos servidos por redes férreas, têm a missão de embarcar os produtos exportados oriundos da Bacia do Prata.

A geopolítica brasileira atraiu as estradas que partem do Uruguai e Paraguai, além dos trilhos da Bolívia, por onde passam diversas mercadorias para serem embarcadas nos Portos brasileiros. A bacia platina possui importantes hidroelétricas que aproveitam o potencial hidroelétrico, como Itaipu, Acarai, Corpus e Apipé.

Atualmente o Rio Paraná constitui em importante elo de ligação entre Argentina, Brasil e Paraguai, tanto energético quanto de aliança regional. Enfim, a Bacia do Prata cumpre um importante papel de exercer a "atração" geopolítica de diversos países Sul-Americanos para o Brasil, de forma que várias vantagens relacionadas à circulação, especialmente via matriz

\footnotetext{
2 A Bacia do Prata é inferior a apenas quatro bacias do mundo: a Amazônica, a do Congo, a do Obi e do Mississipi (CASTRO, 1986: 25).

${ }^{3}$ A Província Cisplatina deixou de ser brasileira em 1828 e se tornou o Uruguai (MAGNOLI, 1997, p. 256).
} 
ferroviária, podem ser criadas para todos os países envolvidos. Castro (1986, p. 22) analisa que "ao se estender os trilhos conectando a Bolívia ao Chile (cidade de Arica) e a conexão brasileira, está posto um verdadeiro corredor Atlântico - Pacífico. Enorme vantagem seria criada para o Brasil com o acesso ao Pacífico".

Esse corredor ferroviário continental de acesso ao Pacífico poderia se constituir em grande elemento de vantagem, pois, os negócios com o Sudeste Asiático ganhariam competitividade devido à menor distância percorrida pelas mercadorias. A lógica se pauta em evitar as grandes distâncias marítimas percorridas para contornar a América do Sul até alcançar o Oceano Pacífico, seja através do Canal do Panamá, ou pelo estreito de Drake, ao sul do continente.

Juntamente ao estudo da Bacia Platina, é preciso analisar também a geopolítica da Bacia Amazônica, uma vez que ambas se integram no centro do território brasileiro. O interflúvio entre ambas serviu como referência inclusive para a divisão dos Estados de Mato Grosso e Mato Grosso do Sul. A partir desse entendimento, tem-se em a lógica das bacias que "correm" no sentido sul (Platina) e no sentido norte (Amazônica) do país.

A Bacia Amazônica é uma sub-região de conexão entre duas áreas de importância geoestratégica - o Caribe e o Altiplano Boliviano (considerado o heartland da América do Sul). Ressalta-se o fato do Rio Amazonas ser o maior do mundo em volume de água e em extensão com aproximadamente $6.992,06 \mathrm{~km}$.

Já a Amazônia brasileira ocupa 2/3 do território do país, com 5.030.109 Km². Dado o seu tamanho e importância foi aprovado o Decreto - Lei $\mathrm{n}^{\circ}$ 1.164, assinado em 1971, o qual declarou indispensáveis à Segurança Nacional as terras devolutas localizadas na faixa de 100 km às margens das rodovias da Amazônia Legal.

Para garantir a circulação nacional, foram construídas várias rodovias, destacando-se a Transamazônica, de João Pessoa a Boqueirão, e por ela chegar ao Pacífico através do Peru (planejada). Embora pavimentada entre João Pessoa até o Pará, ainda permanece inacabada entre o Pará e o Amazonas, e apenas planejada do Amazonas ao Acre. O Cuiabá - Porto Velho (RO) - La Paz (Bolívia) está em operação há anos. A planejada Perimetral Norte, pretensa nova ligação com o Atlântico e acesso às fronteiras das Guianas, Venezuela e Colômbia, e daí o Caribe (países da América Central) ainda não saiu do papel. A figura três detalha a geopolítica estratégica da Amazônia. 
Figura 3: Geoestratégia da Amazônia.

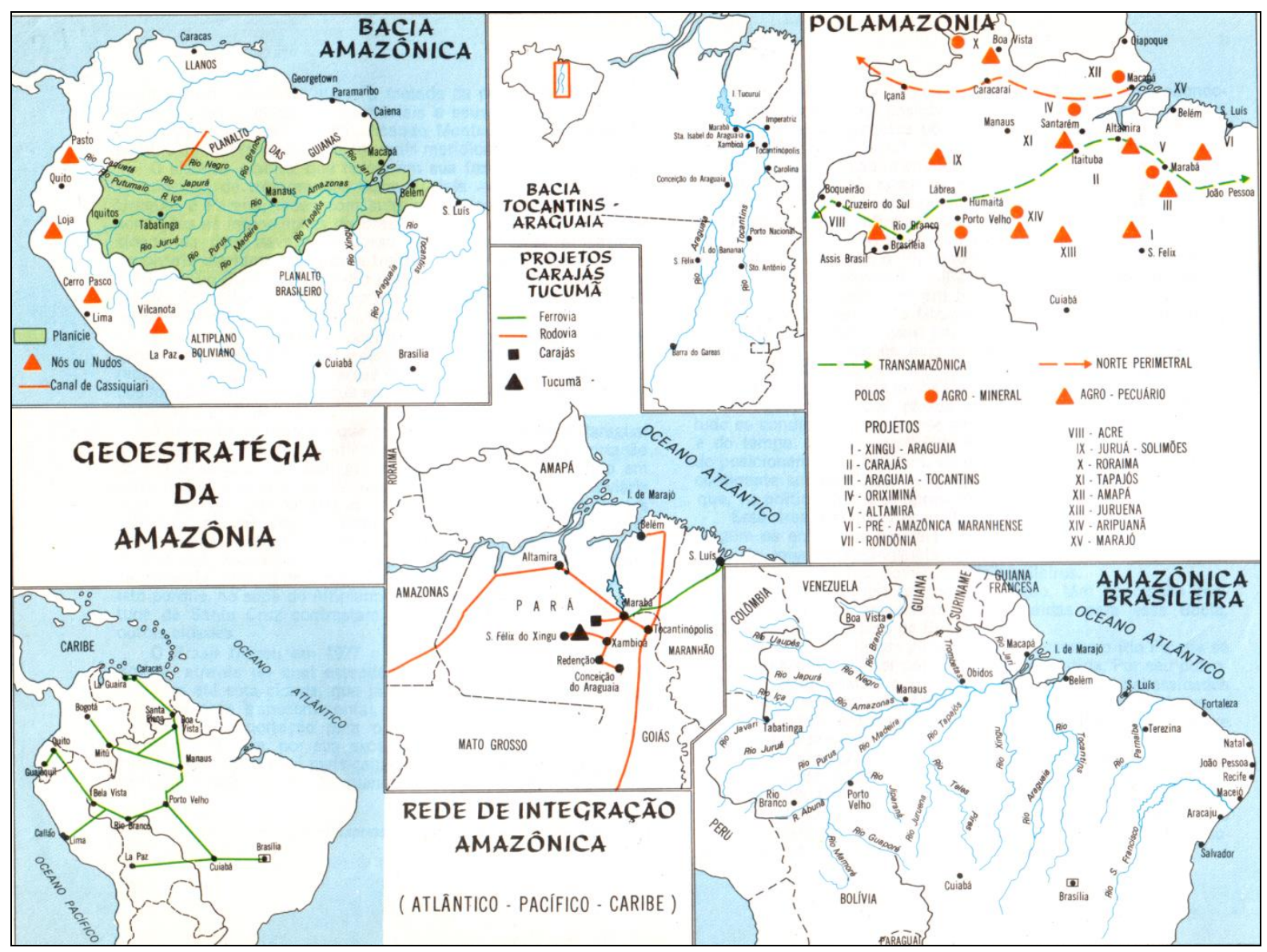

Fonte: Castro, 1986: 27.

Toda esta estratégia de construção de importantes vias de transportes visou não apenas a integração continental a favor do Brasil, mas também a sua própria proteção e o favorecimento do crescimento econômico. A ferrovia Madeira Mamoré que durante décadas foi responsável pela logística entre a cidade de Guajará Mirim, em Rondônia, fronteira com a Bolívia, até a hidrovia Rio Madeira, na altura de Porto Velho, acabou desativada no final dos anos 1980, devido à construção de uma rodovia que substituiu a sua função.

A falta de atualização tecnológica acabou por tornar tal ferrovia antieconômica. Para se ter uma ideia, em plena década de 1980 ainda utilizavam locomotivas à vapor. A importância em estabelecer estratégias eficazes de incorporação do território via rede logística adequada é ressaltada por Silva (1981, p. 169) “a sobrevivência, essencial é ainda a manutenção do território, base física do Estado, uma vez que sua mutilação redundará, em qualquer caso, em prejuízo da integração e em redução do bem-estar, da prosperidade e do prestígio nacionais”.

Ou seja, a preocupação maior das vias de integração é garantir a posse do solo pátrio, evitando que este seja incorporado por outras nações, e ainda, o desenvolvimento da 
economia. Portanto, o Estado no seu papel de guardião do poder nacional e promotor do crescimento econômico, sempre busca alternativas para alcançar seus objetivos. No caso brasileiro, a preocupação em explorar o oeste brasileiro e a Amazônia foi colocada em prioridade, disponibilizando adequada circulação.

Velho (1972, p. 26) observa que "com a construção da Transamazônica e a retirada de minério no Projeto Grande Carajás, ocorre uma grande mudança na dinâmica social e econômica na região de Marabá e entorno". O autor comenta ainda que a região, se bem aproveitada pode oferecer um grande potencial para assentamentos agrícolas e outros investimentos. Ressalta que o minério retirado é transportado pela Estrada de Ferro Carajás, que liga a cidade de Parauapebas no Pará, até o Porto de Itaqui, no Maranhão. Um detalhe importante a ser registrado, é que a citada ferrovia também desempenha importante papel no transporte de passageiros na região.

Aliado ao contexto estratégico amazônico tem-se também, dentro da análise geopolítica brasileira, o potencial estratégico do Nordeste brasileiro. O posicionamento do Nordeste Brasileiro é altamente estratégico, conforme demonstrado na $2^{\mathrm{a}}$ Guerra Mundial, especialmente quando compreendido à luz da teoria do poder terrestre e do poder marítimo. Como é o ponto do continente americano do lado atlântico mais próximo do "velho mundo", foi intensamente utilizado pelos aliados como base de apoio para a travessia oceânica, especialmente dos aviões. Portanto, é fundamental para a defesa nacional. Ressalta-se que o Nordeste brasileiro possui uma importante estrutura ferroviária, cujas origens remontam ao século XIX.

Da mesma forma que o Nordeste brasileiro, o Brasil Central, área que incorpora os Estados de Goiás, Tocantins, o Distrito Federal e o Triângulo Mineiro, tem um papel muito importante na "geopolítica brasileira". O seu papel é proporcionar a base e a coordenação da integração nacional, especialmente do oeste e da Amazônia ao restante do país. Como está localizado no centro geográfico da nação e tem em seu território o divisor natural das bacias hidrográficas que seguem para o Norte (Amazônica), Leste (São Francisco) e Sul (Prata), o Brasil Central é considerado como o "nó" da integração nacional. Segundo Silva,

O grande planalto central, pela sua permeabilidade, seu relevo peneplanado, vestimenta florística mais ou menos uniforme e clima que pouco varia, dá unidade ao conjunto - como Saint - Hilaire não escapou - pois os rios que aí penetram de todos os quadrantes, chegando quase a estabelecer a continuidade entre as três principais bacias, não conseguem de forma alguma dissociá-lo, antes que se dobram e se prestam à sua poderosa ação unificadora que só deixa de se fazer sentir na periferia do território onde as forças de atração do Amazonas e do Prata, muitas em parte atenuadas pelas quebras de perfil, depois de lutarem pela supremacia na região 
instável de Cuiabá - Cáceres - Mato Grosso, decididamente se afirmam cada vez mais para o norte e para o sul (1981, p. 39).

O relevo levemente ondulado desta região proporcionou o avanço das frentes pioneiras, uma vez que conferiu mobilidade e integração do núcleo estatal com os chamados vazios demográficos. A população que antes era rarefeita e concentrada em alguns núcleos populacionais começa a aumentar pelos constantes fluxos de migrantes que paulatinamente se instalam na região, utilizando-se principalmente das ferrovias que ligam o Brasil - Central ao litoral do Sudeste.

Sena (1999) ressalta que essa área do país é a solução nacional para muitos problemas, dado ao grande potencial agrícola e à grande quantidade de investimentos recebidos nos últimos anos, especialmente industriais e comerciais, estimulados a priori pela criação de Goiânia na década de 1930 e de Brasília na década de 1950. Dentro do movimento de ocupação do interior brasileiro conhecido como marcha para o oeste, o Brasil Central foi o elo de conexão entre as regiões Sul, Sudeste e Nordeste rumo ao Oeste e Norte do país. A Marcha para o Oeste materializou o grande esforço governamental para a consecução da manobra de integração do território, via construção de redes logísticas, assentamentos agrários, cidades e estímulos à produção. Tal objetivo seria paulatinamente alcançado a partir da execução em três etapas, as quais Silva (1981, p. 47) esclarece:

\footnotetext{
Dentro do plano de integração nacional, a manobra geopolítica se daria em três fases:

$1^{\mathrm{a}}$ Integração da base ecumênica do Sudeste com a base ecumênica do Nordeste e Sul com o núcleo central do Brasil;

$2^{\mathrm{a}}$ Impulsionar o avanço para noroeste da onda colonizadora, a partir da plataforma central, de modo a integrar a península centro-oeste no todo ecumênico brasileiro;

$3^{\text {a }}$ Inundar de civilização a hiléia amazônica, a coberto dos nódulos fronteiriços, partindo de uma base avançada constituída no Centro - Oeste, em ação coordenada com a progressão $\mathrm{E}-\mathrm{O}$ segundo o eixo do grande rio.
}

A segunda fase de integração corresponde à incorporação do Brasil Central, uma vez que está situado dentro da antiga região Centro - Oeste do Brasil - incluindo o atual Estado do Tocantins. Tal proposta visou o equipamento de meios, principalmente de transportes, inicialmente ferroviário e posteriormente rodoviário, que permitiram ao Brasil Central desempenhar seu duplo papel de sólida plataforma para um transbordamento demográfico sobre a hiléia, ou ainda, para ações visando a contrapor-se a um eventual avanço para o norte de um imperialismo platino sub-reptício ou virulento (IBIDEM). 


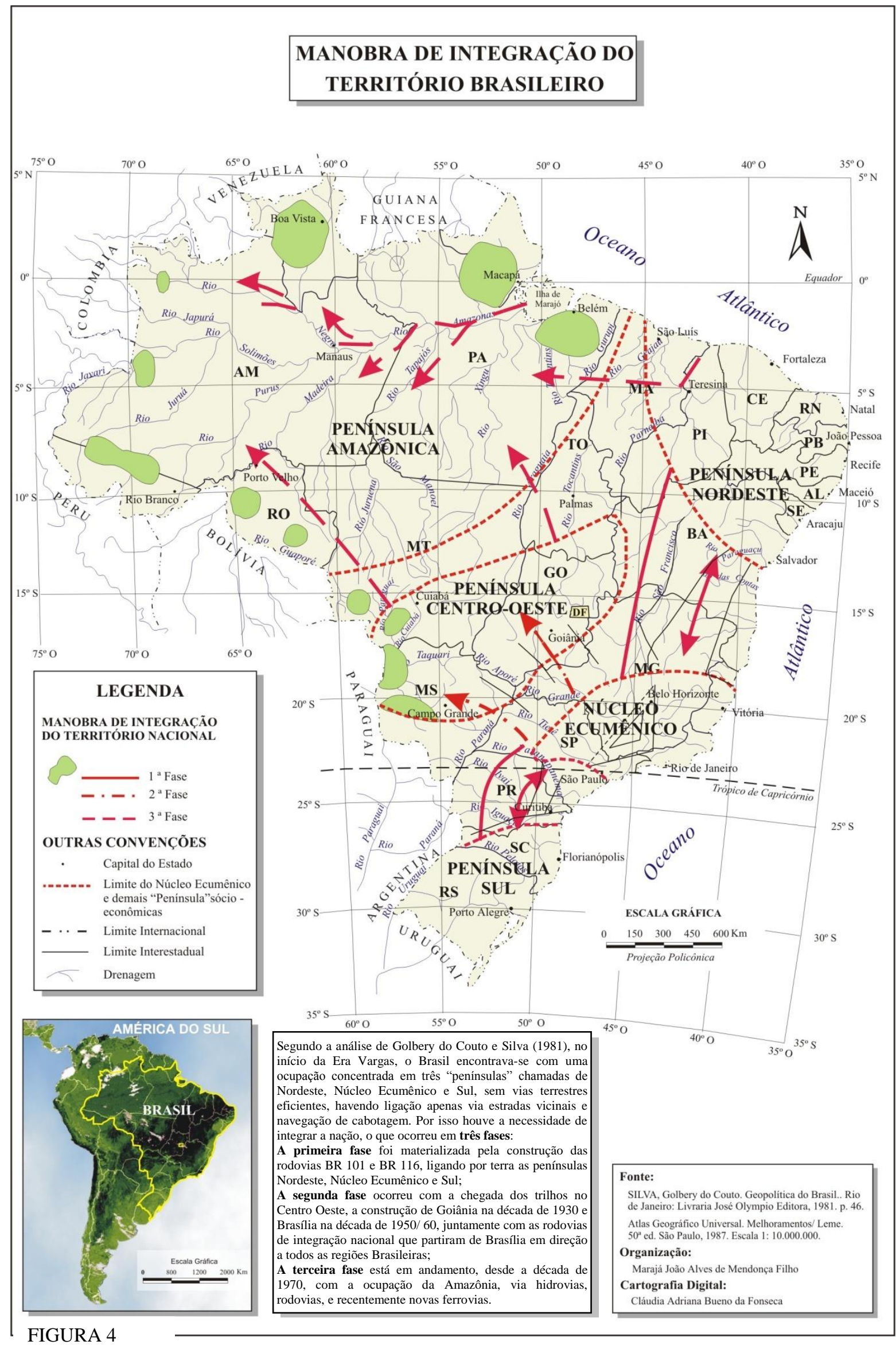

Fonte: MENDONÇA FILHO, 2005, p. 33. 
A figura quatro expressa que ao mesmo tempo em que se planejou reforçar o "heartland" brasileiro visando a integração nacional, especialmente como corredor para a ocupação da Amazônia, almejou-se também fortalecer a infraestrutura de transportes com o incremento de novas vias de acesso, que assim, também ampliaram seu poder. As vias de acesso já instalados no Brasil Central, especialmente as ferrovias, receberam a missão não apenas de favorecer o seu próprio desenvolvimento, mas também, de integrá-lo as demais regiões, enfatizando o desenvolvimento nacional.

Na visão de Silva (1981), o núcleo central ecumênico do Brasil, onde o Estado de Goiás está situado, amplia-se para uma área geopolítica de reserva geral ou de manobra central. Esta incorporaria necessariamente, a totalidade do Estado de Minas Gerais e o restante do Espírito Santo, espraiando-se, ao impulso da interiorização da Capital, por todo o sul de Goiás, de modo que o triângulo de potência ia se alargando firmemente para o quadrilátero tão bem dotado de São Paulo - Rio - Vitória - Belo Horizonte. Por fim, acabaria por estirar-se ainda mais a noroeste para fincar seu vértice interior na região de Brasília, possibilitando afinal a articulação que faltava com a atual ilha amazônica, ao longo do Rio Tocantins e do traçado paralelo da BR 153.

No âmbito externo, o problema fundamental da geopolítica é, primeiramente de natureza propriamente estratégica e não poderia deixar de objetivar a salvaguarda da inviolabilidade territorial, diante de ameaças externas de quaisquer origens que sejam, mesmo que nos afigurem por pouco prováveis. Ora, ainda sob tal aspecto, avulta de importância, na frente continental, o fortalecimento de nossa base ecumênica, a exigir uma sólida e permanente articulação de norte a sul, seja via ferrovias e rodovias, além de hidrovias e aerovias. Da mesma forma, a integração do Centro - Oeste, configurará uma área de inigualável importância estratégica no coração do continente e em condições de permitir reação eficaz a qualquer aventura expansionista, que venha a surgir por esses lados.

O Brasil viveu um intenso crescimento demográfico na década de 1950 para 1960. Particularmente o Estado de Goiás é privilegiado neste período histórico pelo posicionamento que constitui, como já foi dito, o heartland central brasileiro. O Mato Grosso Goiano e o sul do Estado de Mato Grosso do Sul foram as primeiras áreas a serem ocupadas. A interiorização da Capital Federal acabou reorientando toda a rede circulatória de transportes do país, vindo a ajudar a ocupação da extremidade setentrional do heartland central, cujo dinamismo foi multiplicado posteriormente rumo ao noroeste do território. 
Dentro da geopolítica nacional elaborada após a Segunda Guerra Mundial, Goiás foi considerado a título de meta a ser alcançada, como a área geopolítica de reserva geral ou de manobra central, sobretudo pela posição central e pelo acesso favorável vida rede logística de ferrovias, e mais tarde, rodovias. Com as novas modificações estratégicas, esta área passa a ser inicialmente composta por: São Paulo, Rio de Janeiro, Espírito Santo, Minas Gerais e o Sul de Goiás com o Distrito Federal estruturado politicamente sobre o próprio heartland central e ecumênico.

As articulações dos eixos de comunicações constituem o alicerce da estratégica, ao articular os pontos geográficos chave da nação com o heartland central. Nesse, o triângulo de potência, que já se vai alargando firmemente para o quadrilátero tão bem dotado de São Paulo - Rio de Janeiro - Vitória e Belo Horizonte, acabou por estirar-se ainda mais a noroeste para fincar seu vértice interior na região de Brasília. Desta forma, possibilitou a articulação que faltava com a atual "ilha Amazônica", ao longo do Rio Tocantins e o traçado da BR - 153. A partir desta geopolítica, as ações do Estado foram direcionadas para a consecução do poder nacional, uma vez que este se torna o grande princípio para a busca da construção do Brasil potência.

Articulando com a área geopolítica de reserva geral foram elaboradas outras quatro áreas geopolíticas: a Ala Sul, a Ala Oeste, a Ala Norte e a Amazônia. Estas áreas exercem diferentes papéis na estratégia brasileira, quer defendendo a costa atlântica, quer protegendo a fronteira continental, e ainda, articulando o crescimento econômico de todo o país, principalmente pelas redes logísticas disponíveis, tanto ferroviárias quanto rodoviárias. Dentro da geopolítica nacional, observa-se que o objetivo central é aperfeiçoar o poder nacional do Brasil (grifos nosso). Na opinião de Silva, o poder nacional pode ser entendido como

\footnotetext{
A expressão integrada dos meios de toda ordem (políticos, psicossociais, econômicos e militares) de que a Nação dispõe, efetivamente, no momento considerado, para promover, no âmbito interno e no campo internacional, a consecução e salvaguarda dos Objetivos Nacionais, a despeito dos antagonismos internos e externos, existentes ou presumíveis.

Esse Poder Nacional é o instrumento unificado da Estratégia. Entretanto, para análise e planejamento, necessário é considerar quatro expressões inter-relacionadas do Poder Nacional: o Poder Político, o Poder Psicossocial, O Poder Econômico e o Poder Militar (1981, p. 156).
}

Maiores detalhes sobre as áreas geopolíticas do território brasileiro e suas interações na integração e na circulação são apresentadas na figura 5. 


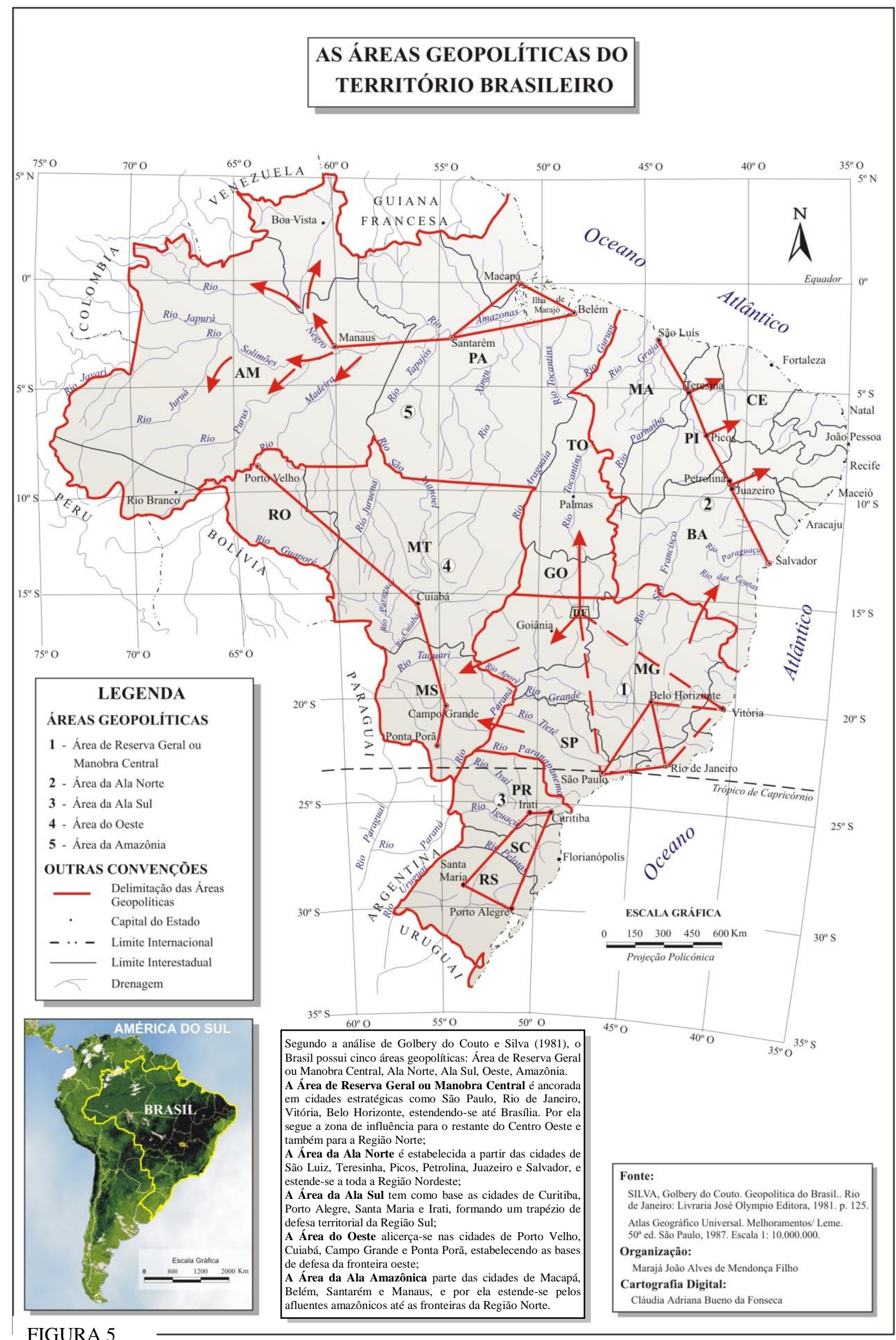

Fonte: MENDONÇA FILHO, 2005, p. 36. 
Contemplando a discussão central deste trabalho, que é a rede ferroviária, observa-se que o poder econômico de uma nação é diretamente interligado com o seu poder nacional, ou seja, quando se discute as ferrovias na área em estudo, se analisa uma estratégia logística diretamente ligada ao poder econômico, dentro do poder nacional brasileiro. Pode-se então compreender que a rede ferroviária está relacionada à própria geopolítica nacional.

As ferrovias em estudo foram criadas dentro de um contexto internacional de Guerra Fria entre o bloco oriental comunista e o bloco ocidental capitalista, do qual o Brasil faz parte. Os países líderes dos blocos desenvolveram tecnologias bélicas para as suas respectivas defesas. Dentre estas tecnologias estão as armas nucleares. Estes, mesmo atribuindo poderes aos países detentores, têm sua utilização totalmente indesejável, pois poderia acionar um possível revide nuclear o que levaria ao total colapso mundial.

Dessa forma, mesmo com a existência de armas sofisticadas, o emprego de tropas nunca foi descartado, pois possibilita uma forma de guerra menos devastadora e arriscada. Assim, a vitória adequada somente poderia ocorrer pela prevalência, ou seja, o bloco que prevalecer sobre o outro é que sairia vitorioso. E essa prevalência ocorrerá pela força econômica, e neste cenário uma eficiente estrutura logística de transportes fará toda a diferença (BRZEZINSKI, s.d.) (grifo nosso).

Portanto, a existência de vias de acesso adequadas, principalmente ferrovias, em quantidade suficiente e estrategicamente posicionadas tornou-se fundamental para garantir o poder, sobretudo econômico dos países de ambos os blocos. A necessidade de uma certa "guerra branca", ou em outros termos, uma continuada demonstração de poderio bélico, militar e econômico, estabeleceria uma ação de imponência com a consequente intimidação do provável oponente. Em contrapartida, uma nação com um fraco poder nacional se transformaria em alvo de possíveis investidas estrangeiras, pois em caso de frágil defesa, agregada a uma débil economia, mas com grande quantidade de recursos naturais, se tornaria em algo tentador a ser conquistado. Por isso, desde a Guerra fria a preocupação com a economia dirá respeito à própria defesa territorial, e consequentemente, à sobrevivência das nações. Assim, evidencia-se a relação entre ferrovias, economia, geopolítica e segurança dos países.

Baseando-se em tais premissas os estrategistas do poder organizaram toda a Geopolítica Nacional e alguns conceitos foram criados. Dentre os principais, tem-se o Conceito Estratégico Nacional - C. E. N. Este deve ser atualizado permanentemente, pois é o referencial principal para os demais conceitos envolvidos na geoestratégia nacional. O C. E. 
N. define em linhas gerais os Objetivos Nacionais Atuais e as correspondentes linhas de ação adotadas (SILVA, 1981).

Dentro dos momentos históricos, pode-se observar que antes da Primeira Guerra Mundial a estratégia de defesa nacional era pautada especialmente no Poder Terrestre, conforme os estudos feitos por Mackinder, já comentado anteriormente, e Ratzel. O conceito de heartland foi fortemente difundido em todo o mundo, provocando no Brasil uma adaptação ao contexto geopolítico Sul - Americano. A preocupação com a conquista do heartland foi materializada nas políticas expansionistas dos Estados.

A Marcha para o Oeste representou a ocupação do heartland brasileiro como estratégia de defesa e de crescimento econômico e social do país. Nesta época o almirante estadunidense Alfred Mahan desenvolveu a teoria do poder marítimo que visava o estabelecimento de estratégias de contraposição eficaz ao poder terrestre. A existência de um litoral com um bom posicionamento e devidamente explorado através do comércio, com a proteção das rotas marítimas e dos principais estuários garantiria o poder marítimo brasileiro. Tal exploração foi feita a partir da construção de importantes portos no litoral do Brasil, os quais são em boa parte servidos por redes ferrovias e rodoviárias que os integram ao interior do país.

No período da Segunda Guerra Mundial a concepção geopolítica de Spykman, conforme já abordado, influenciou fortemente a geopolítica brasileira do Pós Segunda Guerra Mundial. A estratégia do "envolvimento" foi materializada nas vias de integração nacional e continental, na qual o Brasil procurou conectar determinados países do continente sul americano com o objetivo de exercer um forte campo de prevalência política. A Bolívia, o Paraguai e o Uruguai foram atraídos pelas vias de acesso brasileiras, tanto rodovias quanto ferrovias, até os portos internacionais do Brasil, auxiliando nas exportações destes países (grifo nosso).

Ainda neste período, a geopolítica do Poder Aéreo refletiu na construção de bases aéreas estratégicas em todo o Brasil, uma vez que a noção de proteção pela distância só é considerada quando o país possui uma força aérea eficaz. No caso brasileiro, não apenas a construção de bases, mas também, a compra de modernas aeronaves e radares e o investimento na aquisição de tecnologia aeroespacial foram priorizados para a defesa do vasto território nacional. O desenvolvimento de uma adequada aviação comercial para o transporte de passageiros e cargas também foi importante para a integração nacional e o desenvolvimento econômico, especialmente em regiões com poucas vias terrestres, como a Amazônia. 
A Empresa Brasileira de Aeronáutica - EMBRAER materializa a aquisição e posse de tecnologia aeroespacial brasileira, fundamental para a segurança e para a integração nacional através do transporte e da defesa aérea. Em um país de dimensões continentais com o Brasil, não é possível ficar dependente de tecnologia estrangeira para garantir os transportes aéreos. A nação precisa ter capacidade de produzir suas próprias aeronaves. Na área em estudo existem duas bases aéreas: uma em Brasília e outra em Anápolis. Ambas cidades são servidas de ferrovias, em função da grande importância estratégica e logística multimodal.

A materialização da consolidação do heartland brasileiro com a criação de Brasília trouxe um enorme incremento de fluxos de mercadorias e pessoas no Brasil Central, durante o contexto de Guerra Fria. Com o final desta guerra, outras modificações ocorreram, especialmente com a criação de outras ferrovias, como a Norte-Sul, dotadas de modernos equipamentos tecnológicos. Está ocorrendo ainda, a integração ferroviária das malhas férreas do Sudeste com a do Nordeste, do Centro-Oeste, do Norte e do Sul do Brasil, para se adequar ao novo contexto geopolítico nacional, o qual é diretamente influenciado pelo contexto geopolítico mundial.

\subsection{A LOGÍSTICA COLONIAL BRASILEIRA: ESTRADAS REAIS, RIOS E PORTOS}

O início da rede logística brasileira ocorre com a chegada dos portugueses ao Brasil em 1500, estabelecendo-se em pontos chave do território. Nos primeiros 30 anos a ocupação portuguesa na América do Sul foi acanhada, devido sobretudo ao foco dado às riquezas encontradas nas Índias. Neste período foram fundadas as feitorias de Itamaracá (hoje Olinda PE), Santo Aleixo (hoje litoral sul de Pernambuco), Todos os Santos (Salvador - BA), Cabo Frio (Cabo Frio - RJ) e Rio de Janeiro (Angra - RJ).

Contudo, com as ameaças de invasões por parte da França, Inglaterra e Espanha, a expedição colonizadora de Martim Afonso de Souza (1530 - 1532) foi enviada ao Brasil para iniciar a efetiva ocupação do território. Foram fundadas outras duas feitorias: São Vicente (hoje São Vicente, ao lado de Santos - litoral paulista) e Piratininga (hoje São Paulo - SP), que tornaram-se prósperas e contribuíram para o surgimento de novos núcleos urbanos. Desde então o crescimento econômico, urbano e populacional foi grande, e mais tarde, outros 3 centros se destacaram. A figura 6 identifica em vermelho os primeiros núcleos de ocupação. 


\section{LOCALIZAÇÃO DOS PRINCIPAIS FORTES, CIDADES E CENTROS DE POVOAMENTO DO BRASIL EM 1750}
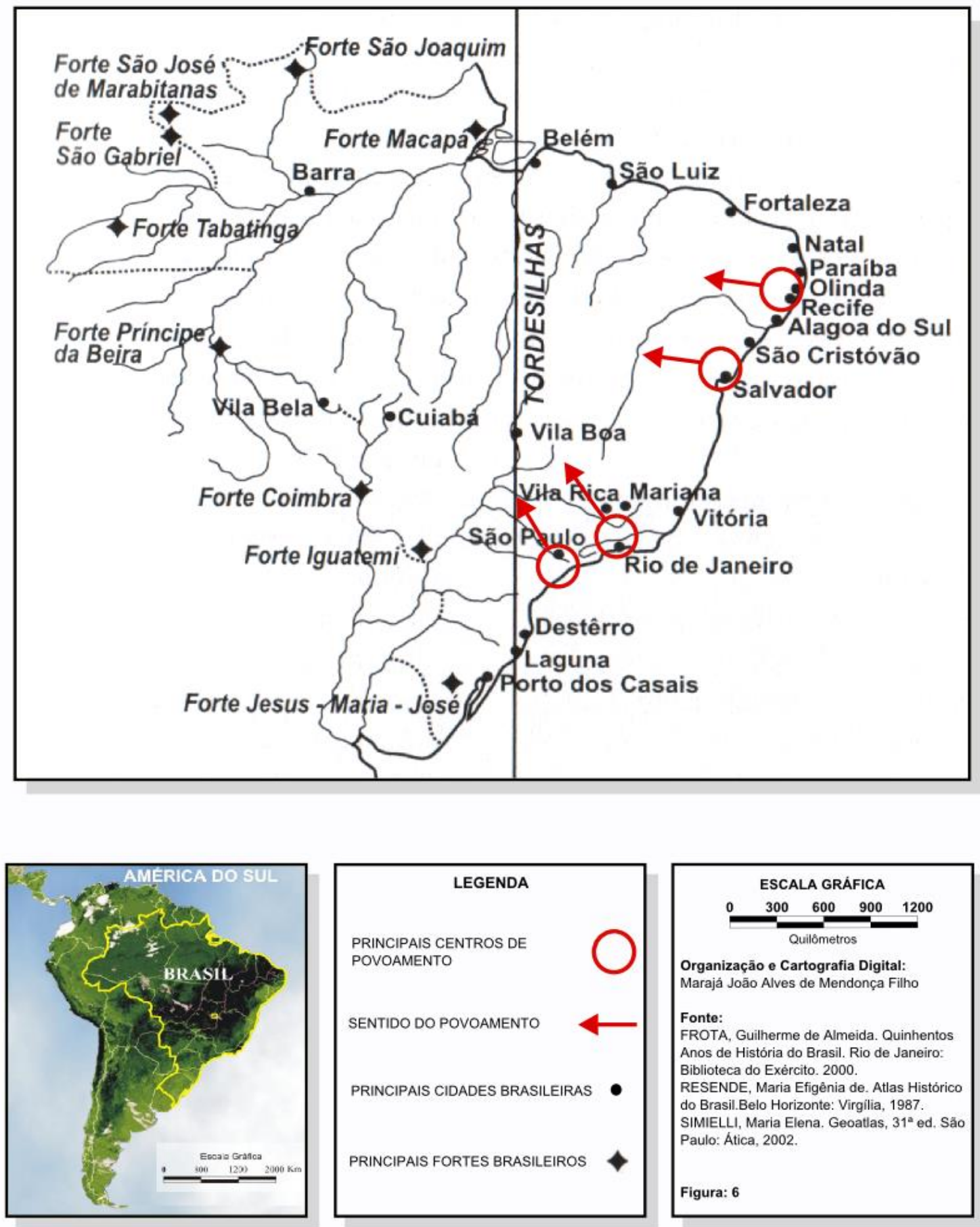
Desde então o crescimento econômico, urbano e populacional foi grande, de modo que no final do século XVI, destacassem quatro centros colonizadores brasileiros: São Vicente, Santos e Santo Amaro (SP); a baia do Rio de Janeiro e a cidade de São Sebastião (RJ); a baia de Todos os Santos e a cidade de Salvador; e a Vila de Olinda e o porto do Recife (PE). Destas cidades ocorreram a paulatina ocupação do litoral brasileiro e das áreas interioranas nas suas proximidades. Com o passar dos anos, várias outras cidades surgiram, até que durante o período da União Ibérica (junção política de Portugal e Espanha por 60 anos), que durou de 1580 a 1640, o país transpôs o limite imposto pelo Meridiano de Tordesilhas e fundou novas cidades e fortificações, resultando em um enorme crescimento territorial do Brasil. As novas áreas adquiridas da Espanha foram regulamentadas pelos Tratados de Utrech (1713) e de Madri (1750), que consolidou o novo território.

O arranjo espacial das cidades no território brasileiro reflete a lógica da circulação, uma vez que as cidades foram construídas em pontos estratégicos, próximos ao litoral, e também nas margens de grandes rios, tudo isso para favorecer os transportes navais, que à época eram os mais modernos. Maiores detalhes podem ser observados no anexo 1. Reflete uma geopolítica de ocupação, desenvolvimento e proteção do território, com o controle de pontos estratégicos, principalmente a Com o descobrimento de minérios preciosos, outras cidades foram fundadas e estradas foram construídas no interior do território.

Tais vias foram chamadas de "Estradas Reais" e tinham como objetivo ligar os pontos mais distantes do território até os grandes centros urbanos do Brasil. Com o aumento do território da colônia, a partir do século XVIII, pode-se criar a Capitania de Goiás, especialmente a partir de 1822, em áreas que antes eram espanholas (além do meridiano de Tordesilhas $-49^{\circ} \mathrm{W}$ ). Portando, o papel da circulação foi fundamental para a instalação de cidades, e também, para o aumento do território via utis possidetis.

Observa-se que dos quatro núcleos litorâneos que foram responsáveis pela ocupação do interior do Brasil, três tem caminhos reais para Goiás e Tocantins. Saindo do litoral paulista, na cidade de São Vicente, seguindo até São Paulo, depois Jundiaí, Mogi-Guaçu, Aguaí, Franca, Igarapava, Uberaba (MG), chegava-se nas cidades goianas de Catalão, Ipameri, Santa Cruz, Bonfim, Meia Ponte e Vila Boa (Capital de Goiás). Do Estado do Rio de Janeiro, outro caminho seguia por Parahyba (RJ), entrando em Minas Gerais, passando por Juiz de Fora, Barbacena, Villa Rica, Sabará, Curvelo, Andreguicé, João Pinheiro, Paracatu, até as cidades goianas de Santa Luzia, Meia Ponte e atingia a capital Villa Boa. 


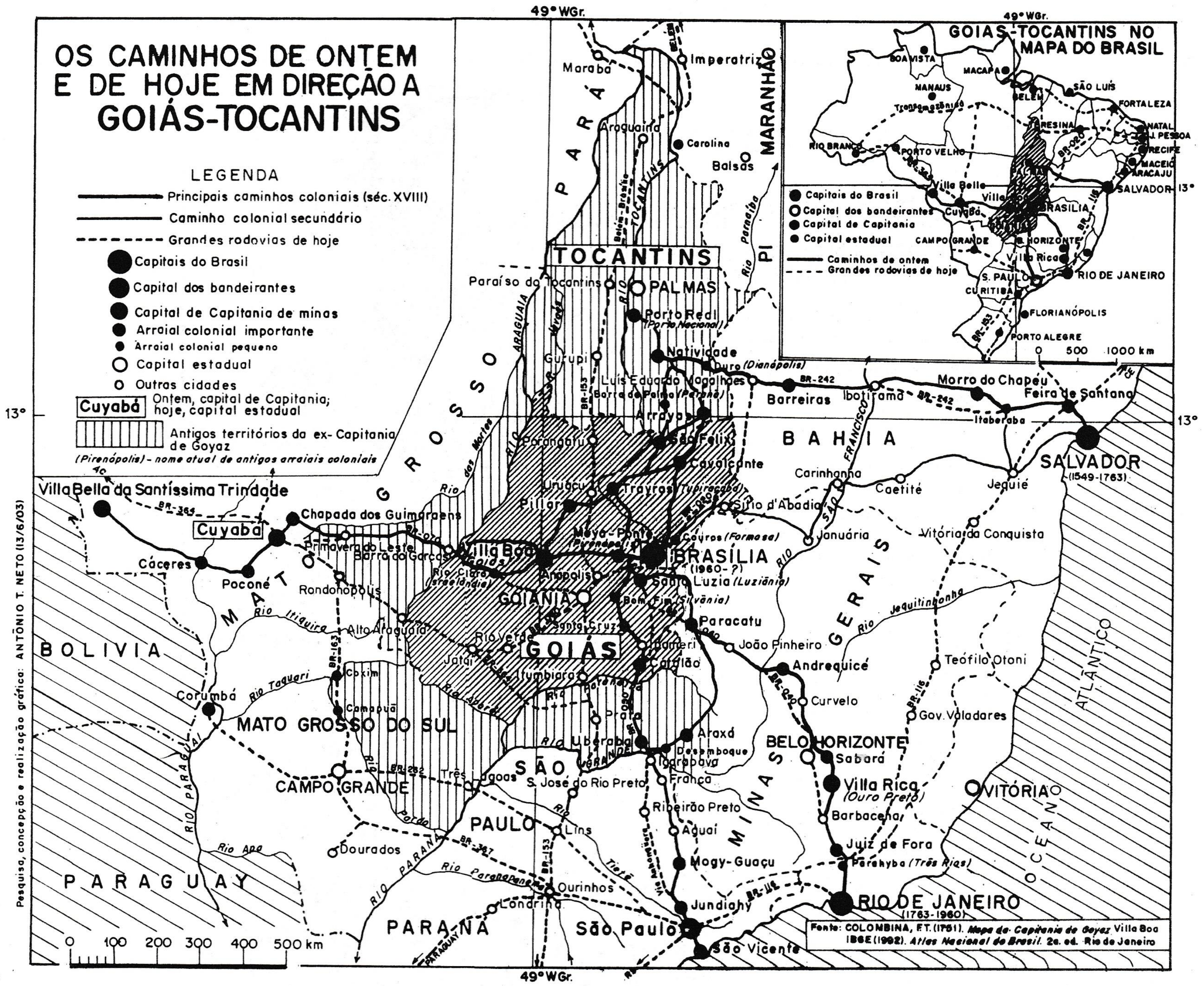


Do Estado do Rio de Janeiro, outro caminho seguia por Parahyba (RJ), entrando em Minas Gerais, passando por Juiz de Fora, Barbacena, Villa Rica, Sabará, Curvelo, Andreguicé, João Pinheiro, Paracatu, até as cidades goianas de Santa Luzia, Meia Ponte e atingia a capital Villa Boa.

A terceira estrada saía de Salvador (BA), passava por Feira de Santana, Itaberaba, Morro do Chapéu, Ibotirama, Barreiras, entrando em solo goiano chegava-se a Duro, Natividade, Arraias, Cavalcante, Couros, Meia Ponte e Villa Boa. Nesta rota ainda havia outra alternativa, a partir da cidade de Natividade, seguindo por São Félix, Traíras, Pillar, chegavase a Villa Boa. De Villa Boa seguia-se pelas cidades de Rio Claro, e entrava em Mato Grosso por Barra do Garça, seguia até a Chapada dos Guimarães até atingir Cuiabá, a capital de Mato Grosso. De Cuiabá atingia-se Poconé, Cáceres e Villa Bella da Santíssima Trindade, esta, quase na fronteira do Brasil com a Bolívia. Até a independência do Brasil, estas foram as principais vias do país. Com o império outra logística foi estabelecida.

\subsection{A MONTAGEM DA REDE FERROVIÁRIA NO BRASIL IMPÉRIO}

A influência do capital privado nos transportes ferroviários brasileiros é marcante, pois desde o início das ferrovias, os recursos privados estivem presentes. A autorização para a construção da primeira ferrovia brasileira data de 1852, feita pelo Imperador brasileiro D. Pedro II a Irineu Evangelista de Souza (1813 - 1889), conhecido como Barão de Mauá. A inauguração foi realizada no dia 30 de abril de $1854^{4}$, e a via ficou conhecida como Estrada de Ferro Mauá (o nome oficial era Imperial Companhia de Navegação a Vapor e Estrada de Ferro Petrópolis), ligando a Praia da Estrela, localizada no fundo da Baia de Guanabara, na cidade do Rio de Janeiro, até a cidade de Fragoso - RJ, com extensão de 14,5 km. Em 16 de janeiro de 1856, os trilhos chegaram até a cidade de Raiz da Serra - RJ, atingindo 15,19 Km.

Na época, Mauá explorava também os serviços de navegação à vapor. A primeira locomotiva foi batizada por D. Pedro II de Baronesa ${ }^{5}$, e circulou até 1884, ou seja, aproximadamente 30 anos (ANPF, 2014). A primeira estação ferroviária do Brasil foi a Guia

\footnotetext{
${ }^{4}$ A Estrada de Ferro Mauá (1854) foi a terceira ferrovia instalada da América do Sul. A primeira foi construída no Peru em 1851, ligando a capital Lima à cidade de Cabalero, enquanto que a segunda foi edificada no Chile em 1852 (ANPF, 2014).

${ }^{5} \mathrm{O}$ nome Baronesa foi dado a primeira locomotiva brasileira por D. Pedro II, em homenagem à esposa do Barão de Mauá, dona Maria Joaquina (IDEM).
} 
de Pacobaíba. Ela não possuía um tamanho muito grande, quando comparada às estações de hoje, por causa do fluxo de transporte de cargas e passageiros que à época era menor.

Figura 8 - Guia de Pacobaíba - a primeira estação ferroviária do Brasil.

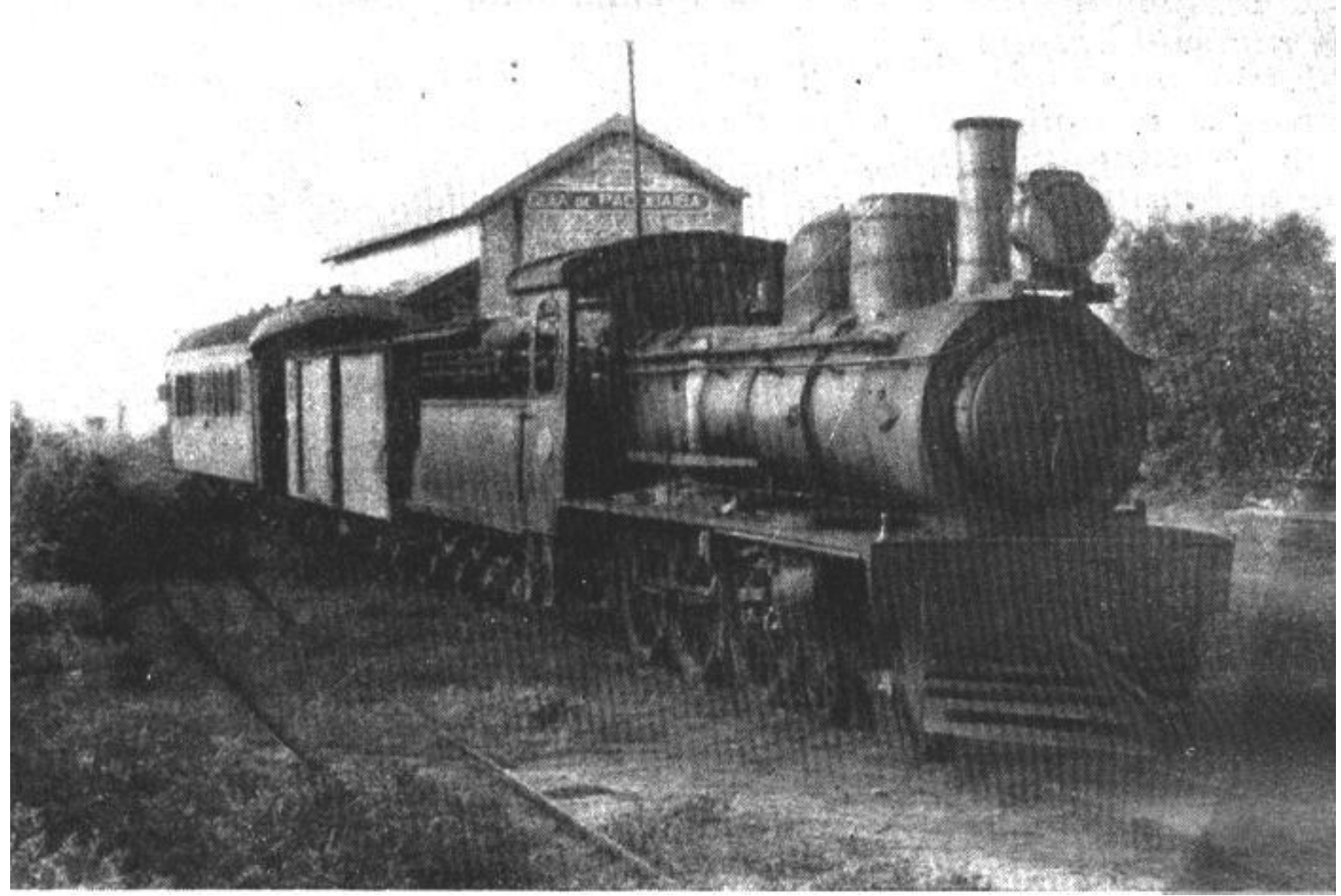

Fonte: ANPF, 2014.

A partir da configuração geopolítica brasileira da época, marcada pela concentração demográfica no litoral, explica-se o ponto de partida das primeiras ferrovias brasileiras. Desta forma, a Guia de Pacobaíba construída no litoral carioca para atender a E.F. Mauá estava ligada à uma plataforma multimodal com integração aquaviária. Desta forma recebia mercadorias e pessoas que chegavam de embarcações e seguiam viagem por terra através de trem, e vice e versa.

Observe a embarcação atracada à esquerda e a locomotiva com seus vagões à direita. $\mathrm{O}$ destino final da ferrovia era a Raiz da Serra, próximo a cidade de Petrópolis, onde ficava a residência de veraneio da família imperial brasileira, na época, um dos municípios mais importantes politicamente do país. Chegar a Petrópolis de trem era um glamour, pois até então o trajeto era feito através de outros meios de transporte, como o cavalo, a carroça, a charrete, ou ainda, a pé. Foi um grande conforto, sobretudo para quem tinha que levar cargas em 
direção à Petrópolis, ou seja, subindo a serra. O trajeto era feito em pouco tempo, sem o desgaste físico dos outros tipos de transporte.

Figura 9 - Integração Multimodal da Ferrovia com a Hidrovia na E.F. Mauá.

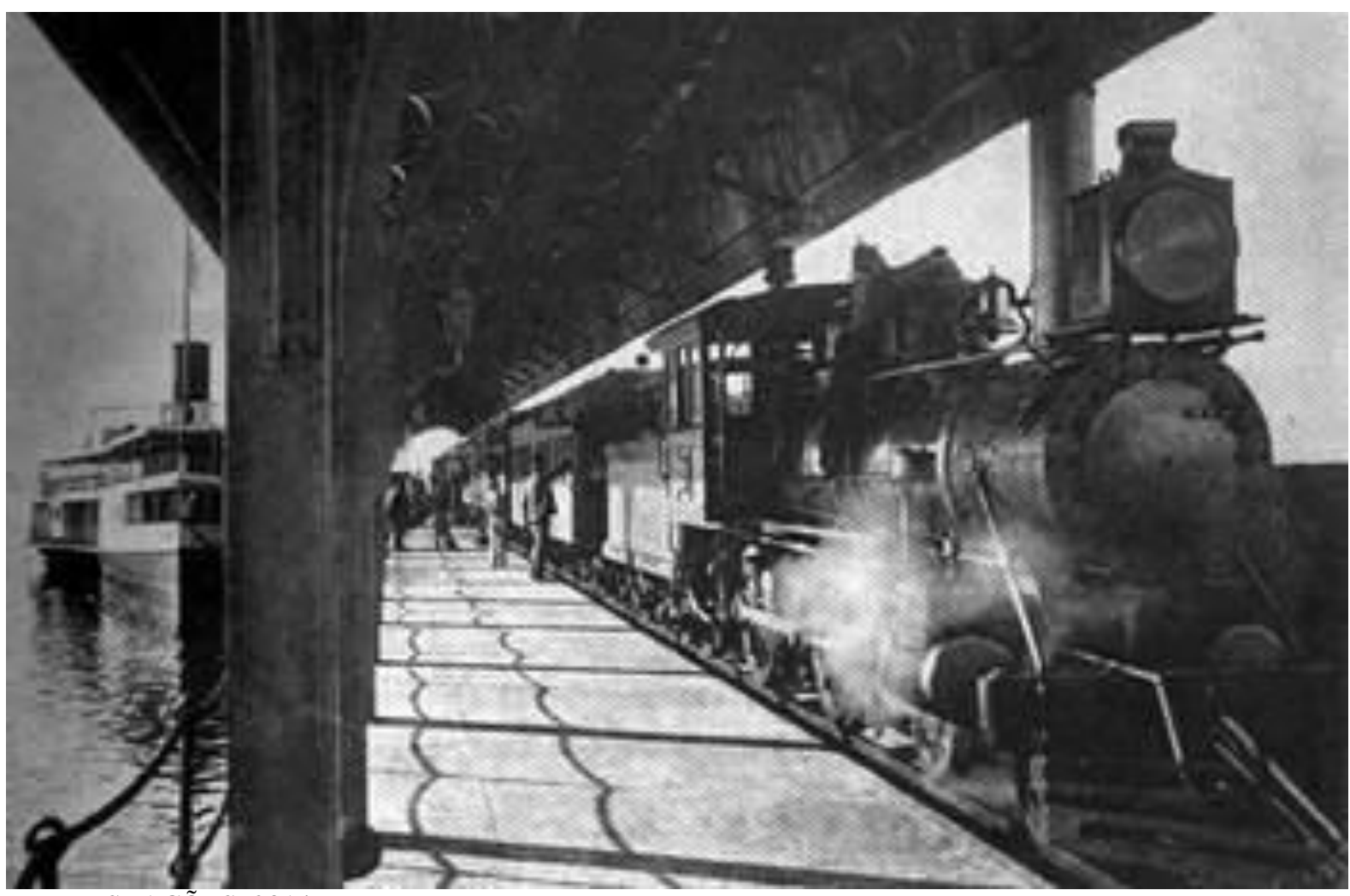

Fonte: ESTAÇÕES, 2014.

A capital imperial, que à época era o Rio de Janeiro, foi o primeiro "nó" da rede ferroviária brasileira que conectava via trilhos a cidade de Petrópolis. O "arco" era representado pelos quatorze quilômetros de trilhos existentes entre as duas cidades. A localização privilegiada no fundo da Baia de Guanabara possibilitava o transporte principalmente de pessoas e mercadorias não apenas de capital federal, a cidade do Rio de Janeiro, mas também oriundo da capital estadual, a cidade de Niterói, e ainda, de outras partes do país e do mundo. Desta forma, a comodidade foi ampliada com o deslocamento dos passageiros que vinha de navios, vindos de diversas origem, até a estação multimodal de Guia da Pacobaíba.

A E.F. Mauá colocou o Brasil dentro do seleto grupo de países detentores de ferrovias e abriu caminho para várias outras que seriam construídas posteriormente. No cenário da modernização mundial vivida no século XIX, a evolução nos transportes torna-se imperativa, pois " $\mathrm{O}$ transporte é uma atividade econômica diferente das outras. A figura 10 mostra o traçado da estrada de ferro Mauá. 
Figura 10 - Mapa Histórico com a Localização e o Traçado da Estrada de Ferro Mauá, ao fundo da Guanabara.

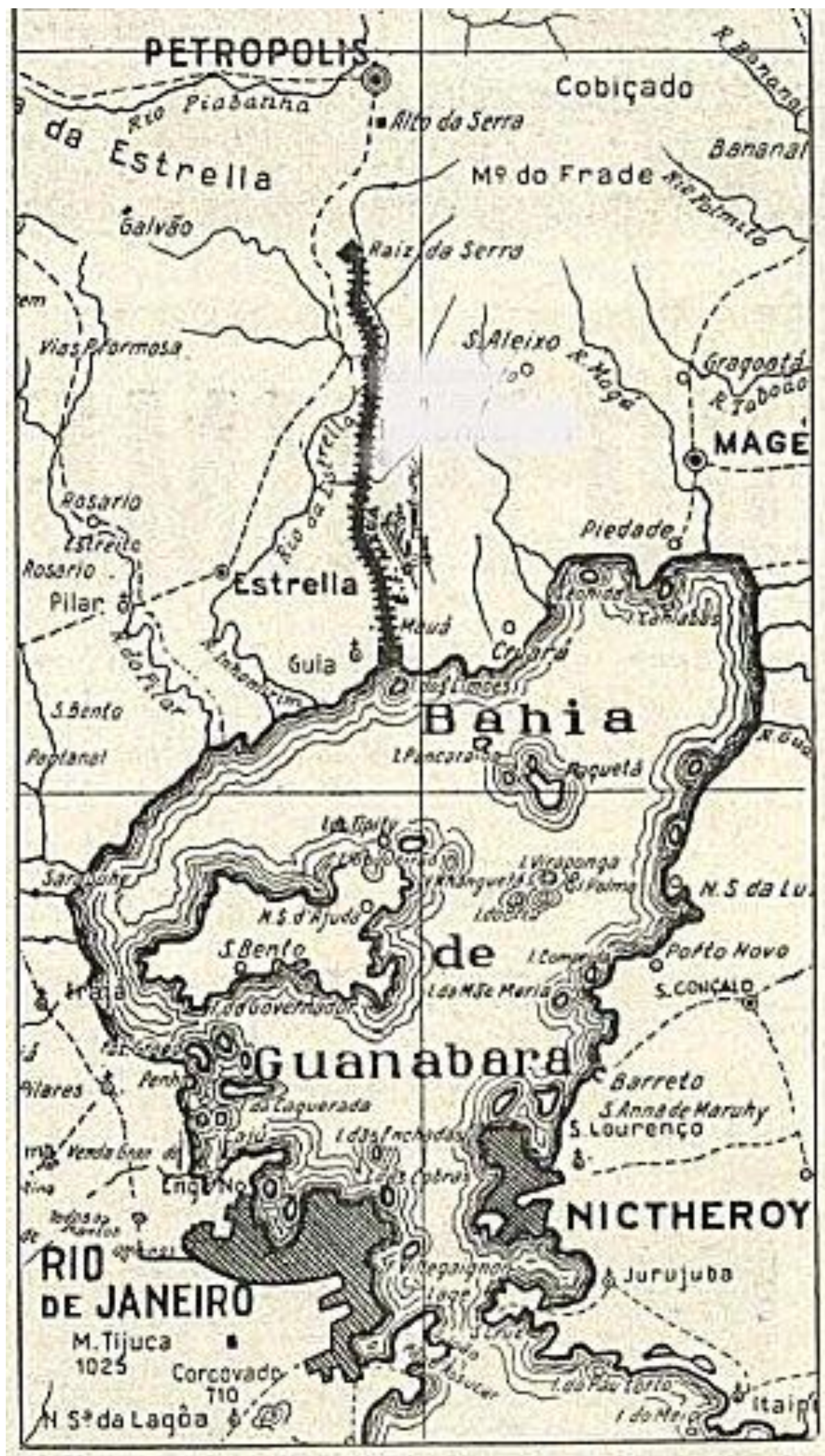

Fonte: ESTAÇÕES, 2014. 
Troca o espaço por tempo e assim por dinheiro" (MERLIN, 1992). Desta forma, é evidente que para evoluir economicamente, e de forma mais rápida, as nações precisavam de investimentos no desenvolvimento dos seus modais de transporte, principalmente no contexto econômico mundial marcado pela expansão da industrialização. Ainda no século XIX, outras ferrovias foram construídas no Brasil no Sudeste e no Nordeste.

Das novas ferrovias, pode se identificar a E.F. Recife ao São Francisco, inaugurada em 08 de fevereiro de 1858; a E.F. D. Pedro II, inaugurada em 29 de março de 1858; a E.F. Bahia ao São Francisco, inaugurada em 28 de junho de 1860; a E.F. Santos a Jundiaí (E.F. São Paulo), inaugurada em 16 de fevereiro de 1867; a E.F. Companhia Paulista, inaugurada em 11 de agosto de 1872; e a ligação Rio de Janeiro - São Paulo, inaugurada em 8 de julho de 1877, unindo os trilhos da E.F. São Paulo com os da E.F. D. Pedro II (ANPF, 2014).

Tais ferrovias comporiam os primeiros nós e arcos da rede ferroviária brasileira e foram importantes para o escoamento tanto da produção brasileira, como também, para o recebimento de mercadorias importadas. Curiosamente, as primeiras ferrovias foram construídas justamente nos locais onde surgiram os primeiros núcleos de ocupação e urbanização do Brasil no século XIX, nos Estados de Pernambuco, Bahia, Rio de Janeiro e São Paulo.

Embora recebessem autorização imperial para a construção das ferrovias, as empresas e investidores particulares as construíam com recursos próprios. Como observado anteriormente, as primeiras estradas de ferro do Brasil nasceram de recursos privados, e não de públicos. Isso se deveu ao fato das ferrovias possibilitarem o deslocamento em grande escala de mercadorias e recursos, responsáveis pelo funcionamento de diversos empreendimentos, principalmente diante da ausência de rodovias ou outras vias terrestres alternativas.

Possibilitou-se assim a instalação de vários negócios novos e a expansão dos já existentes, com o aumento considerável das áreas produtivas cada vez mais distantes do litoral. A construção, o uso e a manutenção das ferrovias pelo capital privado foi um dos fatores de sucesso destas no Brasil. A figura 11 mostra a localização das ferrovias em 1870. 


\section{FERROVIAS NO BRASIL EM 1870}

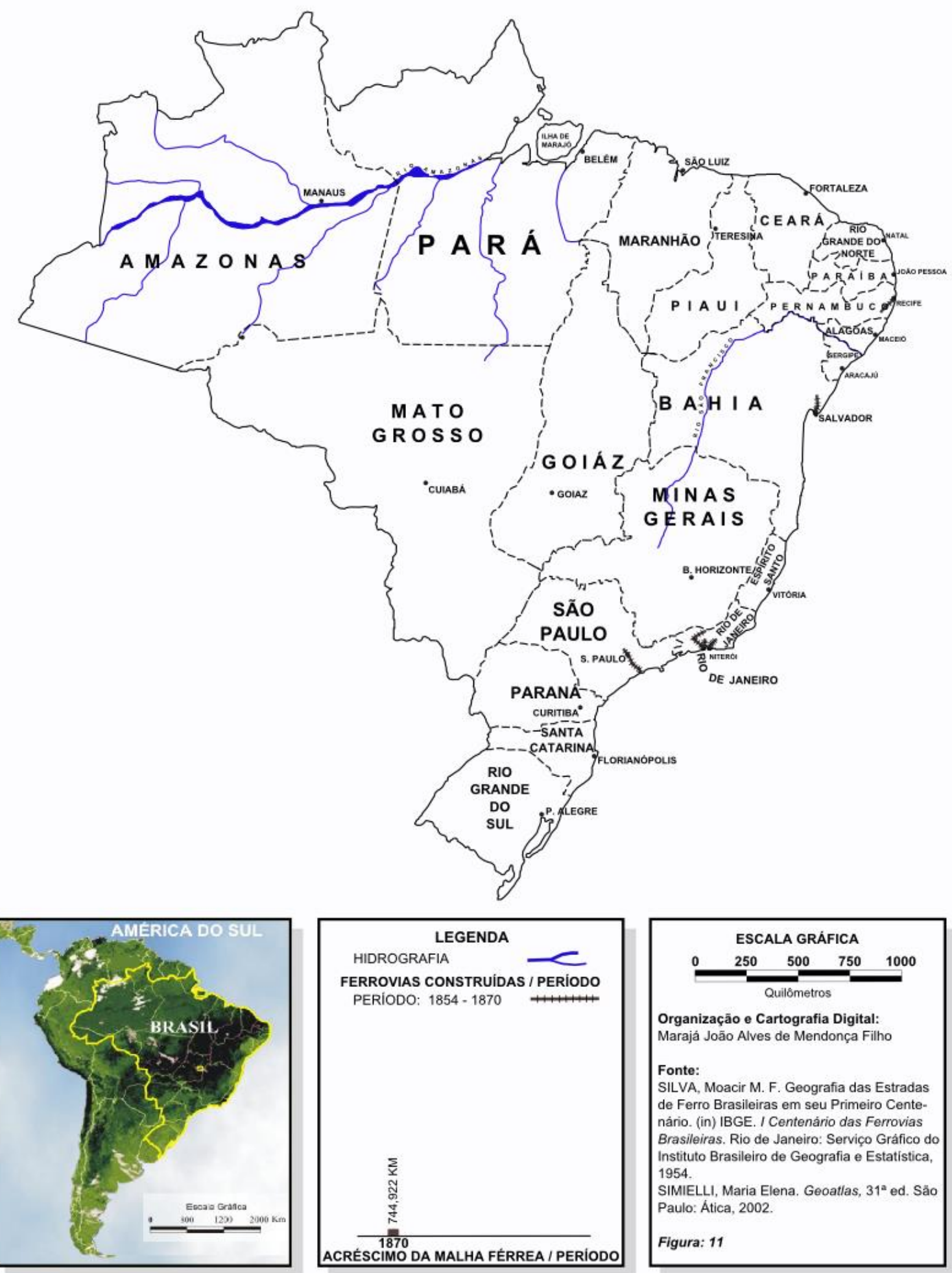


Com um território tão vasto, a existência de várias demandas logísticas por transportes e a falta de estrutura estatal para atender tais necessidades, fez com que a saída estivesse nos investimentos privados. Ao mesmo tempo em que o governo imperial encontrou uma solução para as demandas logísticas do país, o seu papel foi praticamente o de autorizar e regulamentar os serviços. O restante ficou a cargo dos investimentos privados. Com isso, o Imperador D. Pedro II além de economizar os recursos públicos dos impostos, ainda tributava os serviços de transportes, além de arrecadar também com o crescimento econômico da nação.

Vinte anos depois, o incremento em ferrovias era notável alcançando um total de 9.228 km, cooperando para o desenvolvimento do país, a partir da modernização dos transportes. $\mathrm{O}$ ritmo de construção de ferrovias no império atingiu a média de $266 \mathrm{~km}$ por ano, atingindo vários estados de outras regiões brasileiras, com destaque para a maior concentração no Sudeste. A rede ferroviária cresceu em números consideráveis. Tais dados refletem o processo de interiorização da produção brasileira, que passa a incorporar novas áreas do território ao sistema produtivo nacional e internacional. Caracteriza-se assim, o próprio avanço produtivo sobre o território, possibilitado pelo novo panorama da geografia dos transportes.

A partir de 1890 observa-se que os Estados de São Paulo, Rio de Janeiro e Espírito Santo receberam a maior quantidade de ferrovias construídas no período, possibilitando um grande fortalecimento da integração nacional e do crescimento econômico do país. Tais Estados destacavam-se na produção de grãos, em especial o café em São Paulo, além de minérios e outros produtos como carne e manufaturados. A concentração demográfica nestes estados fez com que as ferrovias fossem amplamente utilizadas no transporte de passageiros.

De acordo com a figura 12 à seguir, as ferrovias na cor vermelha no mapa identificam os trechos construídos de 1870 a 1890. A rede ferroviária no Sudeste expressa a força do crescimento econômico da região e a incorporação de áreas situadas no interior dos estados ali situados. Áreas distantes do litoral paulista, o Triângulo Mineiro, o interior de Minas Gerais próximo ao quadrilátero ferrífero e mais tarde Belo Horizonte, também foram alcançados. A rede possibilitava viagens inclusive do interior de Minas Gerais ao litoral paulista, e ainda ao estado do Rio de Janeiro, até a divisa com o Espírito Santo. Algo inédito para a época.

As ferrovias nordestinas também aumentaram consideravelmente nos estados da Bahia e Pernambuco, atingido regiões distantes do litoral. Outras foram construídas nos estados do Ceará, Rio Grande do Norte, Paraíba e Alagoas, ampliando a rede nacional. 


\section{FERROVIAS NO BRASIL EM 1890}

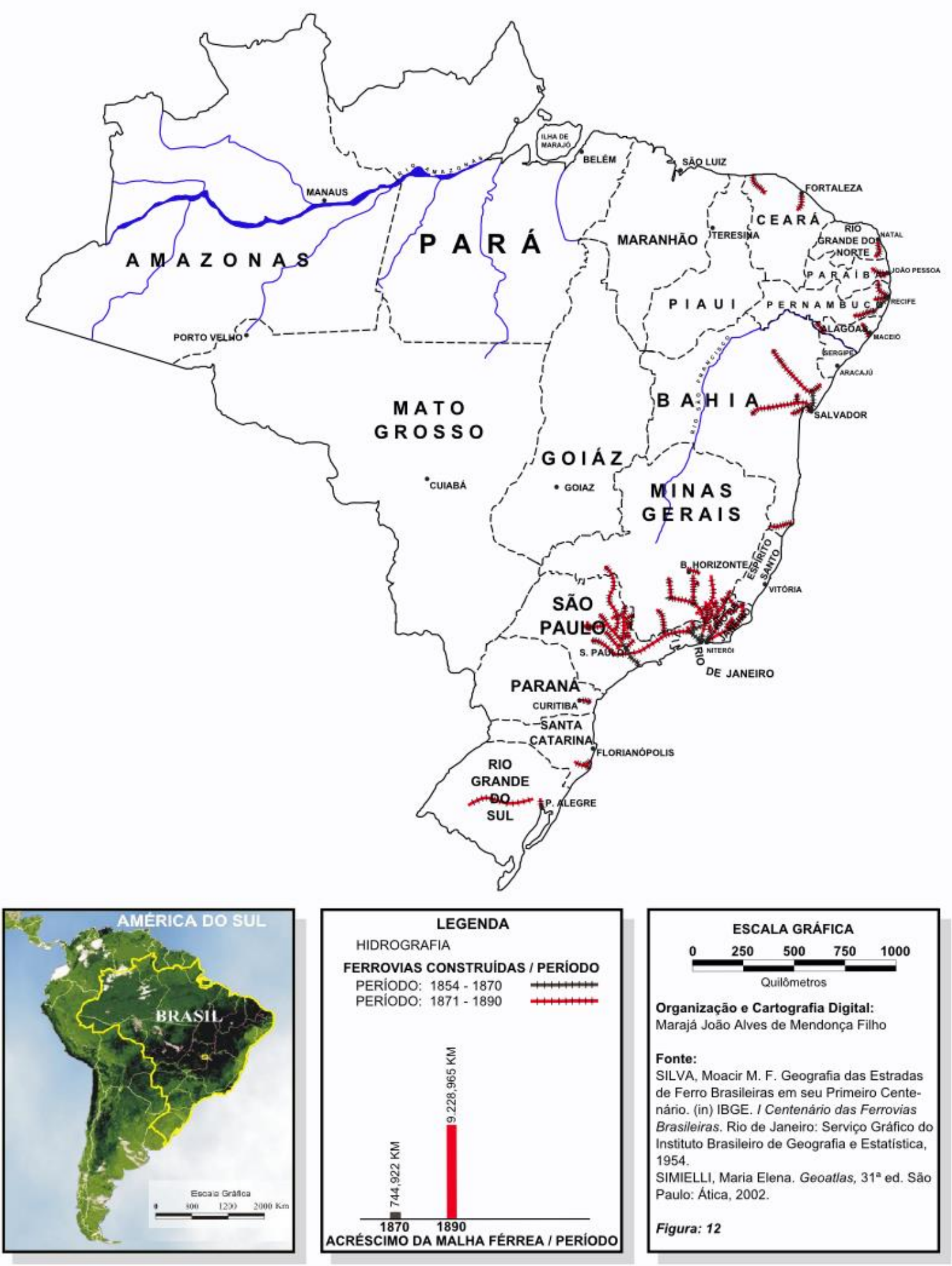


Na região Sul, todos os três estados, Paraná, Santa Catarina e Rio Grande do Sul também passaram a ter suas ferrovias, o que contribuiu para o desenvolvimento econômico da região. É curioso perceber que nesta época, toda a construção ferroviária era propiciada pela extensão dos trilhos já existentes, uma vez que não havia estradas alternativas, e nem outro tipo de transporte mais eficiente, como por exemplo, os caminhões. O que não seguia pelos trilhos tinha que ser levado por carroças ou similares, de tração animal. Outro aspecto a ser destacado é que o Acre ainda não pertencia ao Brasil, e sim a Bolívia, sendo anexado ao território nacional apenas em meados de 1903.

Dada a baixa densidade populacional do interior do país, não existiam os estados de Mato Grosso do Sul, Rondônia, Roraima, Amapá e Tocantins. Ambos ainda faziam parte dos estados de Mato Grosso, Amazonas, Pará e Goiás, respectivamente. Evidencia-se, portanto, uma concentração econômica e populacional nas regiões Nordeste, Sudeste e Sul, com destaque para o litoral e as áreas de influência das ferrovias existentes.

Com base no mapa das ferrovias em 1890, e como já citado anteriormente, observa-se que os estados de São Paulo, Rio de Janeiro e Espírito Santo receberam a maior quantidade de ferrovias construídas no período, possibilitando um grande fortalecimento da integração nacional e do crescimento econômico do país. Tais Estados destacavam-se na produção de grãos, em especial o café em São Paulo, além de minérios e outros produtos como carne e manufaturados. A concentração demográfica nestes estados fez com que as ferrovias fossem amplamente utilizadas no transporte de passageiros. Não foi por acaso que o crescimento das ferrovias foi tão expressivo, como pode ser observado nos últimos anos do império. O gráfico um mostra a quantidade de linhas férreas construídas entre 1881 e 1888.

Gráfico 1 - Construção de estradas de ferro no Brasil entre 1881 e 1888.

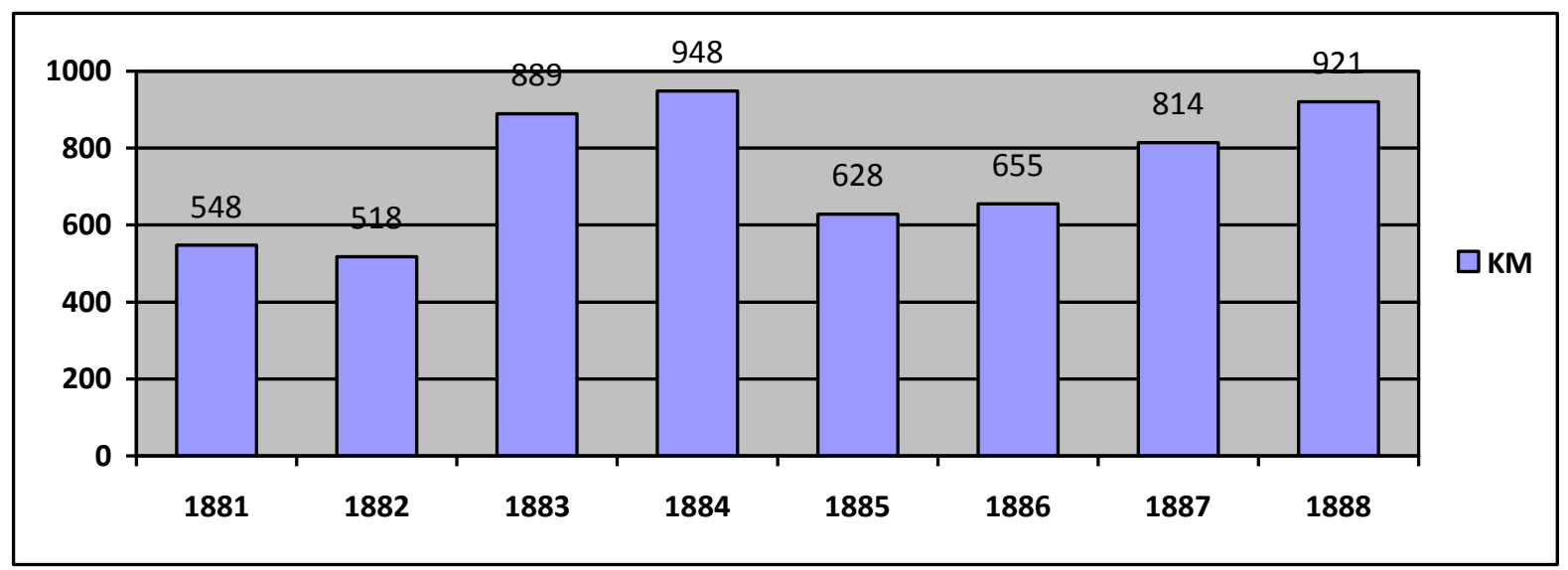

Fonte: IBGE, 1954, p. 4. 
Considerando que o trabalho de construção era praticamente todo artesanal, pois não havia máquinas pesadas para isso, a quantidade é surpreendente. Em anos como 1884 e 1888, a quantidade chegava a quase três quilômetros por dia. Tais construções são resultados de várias concessões que foram outorgadas para a construção de ferrovias, na bitola métrica, destacando-se as seguintes: Companhia Mogiana, em 03 de maio de 1875; Companhia Sorocabana em 10 de julho de 1875; Central da Bahia em 02 de fevereiro de 1876; Santo Amaro em 02 de dezembro de 1880; Paranaguá a Curitiba em 19 de dezembro de 1883; Porto Alegre a Novo Hamburgo, 14 de abril de 1884; Dona Teresa Cristina, em 04 de setembro de 1884 (localizada em SC, com $112 \mathrm{~km}$, destinada ao transporte de carvão de Pedra das Minas para o Porto de Imbituba); Corcovado, em 09 de outubro de 1884; Oeste de Minas (Sítio hoje Antônio Carlos) a São João Del Rey, em 28 de agosto de 1881 (com bitola de 0,76 m). As já citadas E.F. Recife - São Francisco, inaugurada em 1858, e a E.F. Salvador - São Francisco, inaugurada em 1860, as quais foram posteriormente integradas; a E.F. Porto Alegre a São Leopoldo, inaugurada em 1874, com 33,75 Km (ANPF, 2014). Tais dados refletem a diversificação produtiva e geográfica nacional.

Portanto, se em 1884, o país contava com $6.116 \mathrm{~km}$ de ferrovias, além de $1.650 \mathrm{~km}$ em construção, em dezembro de 1888, as ferrovias construídas já atingiram $9.200 \mathrm{~km}$ de extensão, e outros 9.000 km encontrava-se em construção ou estudo, cujos detalhes puderam ser observados na figura 5, anteriormente. Mais uma vez, a força e o valor dos investimentos privados mudaram a paisagem produtiva brasileira.

Ao final da monarquia, em 15 de novembro de 1889, a extensão ferroviária total do Brasil era de mais de $9.200 \mathrm{~km}$ (apurados em 31 de dezembro de 1889). Por outro lado, algumas consequências da política de incentivos à construção de ferrovias, adotadas pelo governo imperial perduram até hoje, como: a grande diversidade de bitolas que vem dificultando a integração operacional entre as ferrovias; traçados de ferrovias excessivamente sinuosos e extensos cujo objetivo era economizar nas obras de engenharia, como aterros, terraplanagem, viadutos e pontes, e localização dispersa e isolada das ferrovias no país (IBGE, 1954).

Essa diversidade de bitolas se deve às diferenças entre as tecnologias empregadas entre países que forneciam as ferrovias, e também aos tipos usados em cada período histórico. Geralmente as bitolas mais estreitas são mais antigas, enquanto que as mais largas são mais modernas e permitem composições maiores e velocidades melhores. Todavia, nos países mais desenvolvidos tais bitolas foram padronizadas e uniformizadas, enquanto que no Brasil, isso 
não ocorreu. Considerava-se mais fácil ajustam o material rodante às bitolas das ferrovias, do que reajustar a bitola de todas elas. De qualquer foram, tais ferrovias marcaram bem o território, refletindo a intensificação de sua ocupação e dinamização econômica, partindo do litoral rumo ao interior, resultando em profundam modificações no ordenamento produtivo nacional, cada vez mais direcionado ao interior.

\subsection{O BRASIL REPÚBLICA: A EXPANSÃO DA REDE E O CONTROLE PÚBLICO E PRIVADO DAS FERROVIAS}

Após a Proclamação da República, várias ferrovias foram construídas e outras ampliadas, principalmente no Estado de São Paulo, em virtude da expansão cafeeira, rumo ao interior. Em São Paulo, de 1867 até 1930, existiam 18 ferrovias, das quais metade com extensões inferiores a $100 \mathrm{~km}$, servindo, portanto, de ramais para as grandes e médias companhias. Os excedentes produtivos que foram se acumulando nas áreas de influência das ferrovias acabaram cooperando no investimento de novas ferrovias, as quais passaram a incorporar regiões cada vez mais distantes do litoral e ampliando o lucro dos investidores. Outros recursos também foram aplicados por investidores internacionais, principalmente ingleses, na expansão ferroviária brasileira, resultando em uma considerável modernização dos transportes.

Destacam se as seguintes ferrovias: E.F. Sorocabana, com 2.074 km; Companhia Mogiana de Estradas de Ferro, com 1.954 km; a E.F. Noroeste do Brasil, com 1.539 km; a Companhia Paulista de Estradas de Ferro, com 1.536 Km; a E.F. Araraquara, com 379 Km. Como resultado da expansão, a rede ganhou ainda a São Paulo Railway com 246 km, que até 1930, consistia em uma única ligação ferroviária do planalto paulista com o Porto de Santos. Segundo o IBGE (1954: 4) já em 1891 as ferrovias brasileiras somavam $11.352 \mathrm{~km}$,

“(...) devido à expansão das linhas dos estados de São Paulo, Rio de Janeiro, Minas Gerais, Rio Grande do Sul; às ligações do interior do Paraná e Santa Catarina e dos estados de Alagoas, Pernambuco, Paraíba e Rio Grande do Norte; ao prolongamento de linhas surgidas no período anterior e ao aparecimento de linhas novas no Espírito Santo, no Pará e em outras unidades da Federação".

Com a República outros investimentos em ferrovias foram feitos em diversos estados, especialmente entre 1890 e 1910, devido ao maior liberalismo econômico, que atraiu mais investimentos privados. A figura 13 mostra os detalhes do posicionamento das ferrovias que foram construídas nas duas primeiras décadas da república, indicando-as na cor laranja. 


\section{FERROVIAS NO BRASIL EM 1910}

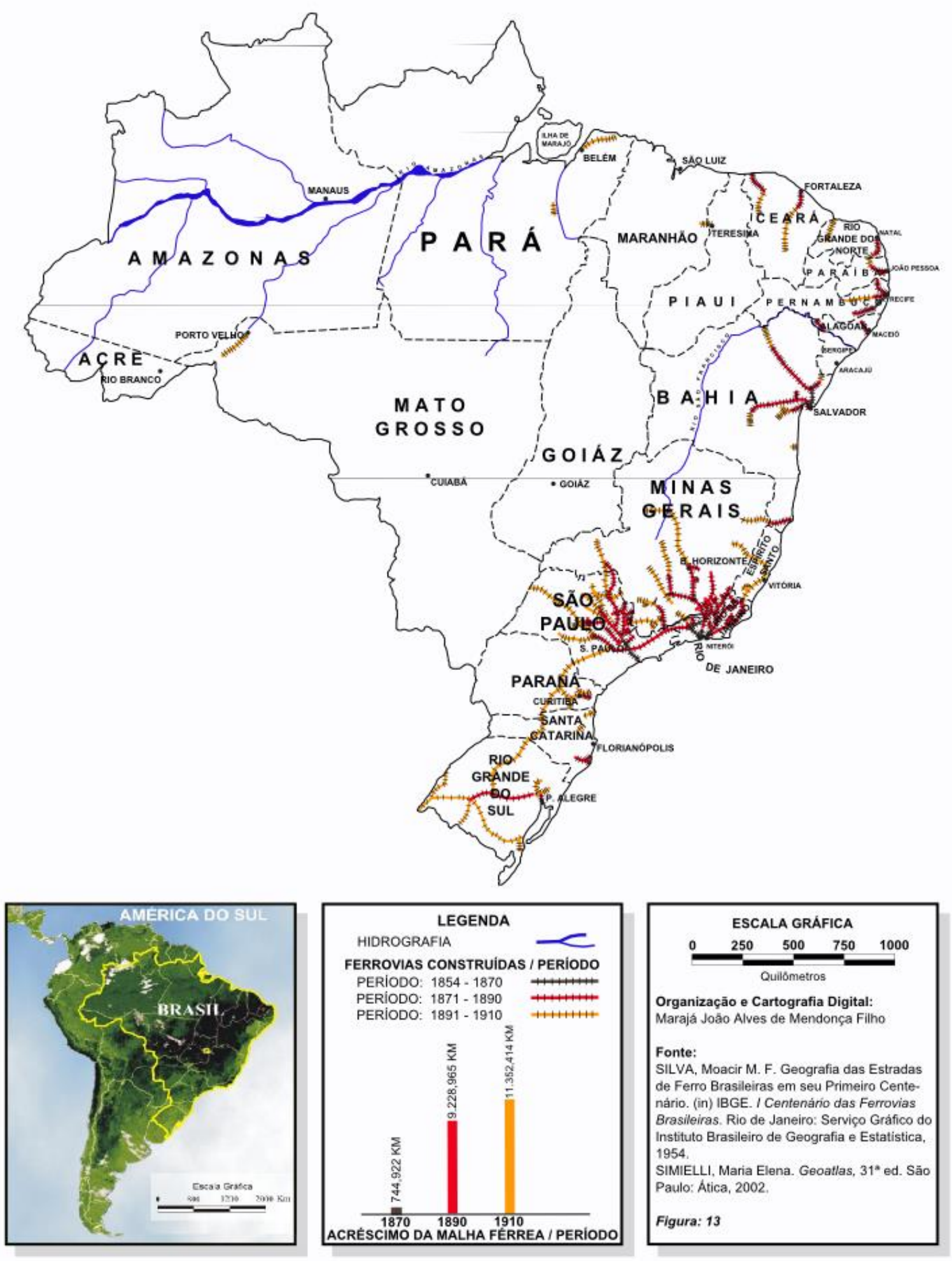


Os incrementos em trilhos permitiram ao Brasil "ao encerrar se o século XIX (em 31 de dezembro de 1899) a extensão ferroviária total (...) de 14.195 quilômetros e meio" (IBGE, 1954: 5). Já no final da década de 1910, houve intensa expansão ferroviária, uma vez que construíram em 1908 um total de $1.027 \mathrm{~km}$, em 1909 mais 608 km e em 1910 atingiu-se o recorde de $2.084 \mathrm{~km}$. Ou seja, foram instalados entre a última década do século XIX e a primeira década do século XX mais de onze mil quilômetros de ferrovias.

Observa-se que as vias férreas crescem irradiando-se das malhas paulista, carioca, mineira, sul-rio-grandense, paraná-catarinense e baiana. Novas ferrovias surgem nos estados de Goiás, Maranhão, Piauí, Mato Grosso, Pernambuco e Bahia, ampliando a rede em novos ramais distribuídos por vários estados da federação. Isso expressa um padrão de ocupação que concentra-se no centro dinâmico da nação, que é o Estado de São Paulo, em direção aos demais estados brasileiros.

Há ainda uma integração das malhas da região Sul com a Sudeste, e pelas ferrovias que chegam ao Rio São Francisco, vindas de Minas Gerais e da Bahia, também uma integração fluvial das malhas da região Sudeste com as do Nordeste. Outras ferrovias regionais se destacaram posteriormente, dentre elas: na E.F. Madeira Mamoré, com 344 km, inaugurada em 1912, ligando Porto Velho a Guajará Mirim (no antigo território federal de Guaporé, hoje estado de Rondônia); a já citada E.F. Noroeste do Brasil, ligando Bauru a Porto Esperança, em 1914, atravessando os Estados de São Paulo e Mato Grosso do Sul, até a cidade de Corumbá, fronteira com a Bolívia (a ponte sobre o Rio Paraguai foi construída somente em 1947) (ANPF, 2014). Investimentos privados de toda a ordem, tanto nacionais quanto estrangeiros, procuravam oportunidades de negócios no território brasileiro, em locais cada vez mais distantes do litoral.

Entre 1911 e 1915, completam se o ciclo de oito anos de maior construção ferroviária do país, atingindo "em 1911 mais 961 quilômetros; em 1912 mais 1.204 quilômetros; em 1913 mais 1.122 quilômetros; e em 1914 mais 1.448 quilômetros, e no ano seguinte 584 quilômetros" (IBGE, 1954: 6). Ou seja, uma considerável extensão ferroviária que melhorou a integração territorial via rede de ferrovias. Segundo Santos e Silveira (2001: 37) "o aparelhamento de portos, a construção de estradas de ferro e as novas formas de participação do país na fase industrial do modo de produção capitalista permitiram às cidades beneficiárias aumentar seu comando sobre o espaço regional". Tais cidades representam os novos nós da rede econômica e logística nacional, estabelecendo relações de comando e controle nas suas áreas de influência. 
Em 1922, ano em que se comemorou o centenário da independência, existiam no Brasil aproximadamente $29.000 \mathrm{~km}$ de trilhos, 2.000 locomotivas a vapor e 30.000 vagões em tráfego. Em 1930, início da "Era Vargas", o total de ferrovias atingiu 31.472 km de extensão. A concentração ferroviária nacional expressa a própria concentração econômica das diversas unidades da federação, destacando-se o papel do Sudeste no comando do processo produtivo do país. Obviamente o nível de concentração das ferrovias retrata a própria necessidade de transporte das mercadorias produzidas em cada área do país. Assim, o mapa das ferrovias expressa o próprio mapa da produção nacional. Até 1930 as ferrovias adensam-se mais.

Segundo Santos e Silveira (2001: 38), “entre 1900 e 1935 iniciaram suas operações no Brasil 133 portos fluviais e marítimos, correspondendo cinco à região Nordeste, três à região Sudeste, três à região Sul e dois à região Norte". Tais portos ligavam-se às ferrovias para o transporte de mercadorias e passageiros, excetuando-se apenas o porto de Manaus, que não estabelecia conexão com nenhuma ferrovia. A expansão da rede ferroviária atinge também a região Centro Oeste, estendendo-se pelos estados de Goiás e Mato Grosso. Destaca-se o papel das ferrovias construídas em Mato Grosso, pois visou-se conectar os países vizinhos Paraguai e Bolívia, com a rede ferroviária brasileira.

A partir de Porto Esperança - MT, cidade próxima a fronteira paraguaia, objetivou-se pelo Sudeste chegar aos portos do Atlântico, como o de Santos. Pelo norte, mais especificamente Porto Velho, que na época pertencia ao Estado de Mato Grosso, quase fronteira com o Estado do Amazonas, chegar a rede hidroviária da bacia Amazônica, via Rio Madeira, por ele ao Rio Amazonas, e posteriormente o Oceano Atlântico. Ressalta-se que em 1930 a cidade de Porto Velho ligava se a Presidente Marques via ferrovia.

A ferrovia que ligava Porto Velho até Presidente Marques era a Madeira Mamoré, que mais tarde atingiu a cidade de Guajará Mirim, na fronteira do Brasil com a Bolívia, tornandose um importante corredor de exportações da Bolívia. Tal ferrovia era parte do acordo de anexação do Acre ao Brasil. Por ela houve grande quantidade de exportação de erva de chá bolivianas, dentre outros produtos, contribuindo não apenas para o desenvolvimento do Brasil, mas também da Bolívia. Veja maiores detalhes no próximo mapa.

Todavia, as concentrações ferroviárias em determinados estados da nação, em detrimento de outros que praticamente não tinham nenhuma, acabou acirrado as desigualdades regionais, e provocou um movimento desigual e combinado na apropriação econômica do Brasil. A figura 14 mostra a localização das ferrovias em seus respectivos estados e evidencia o desequilíbrio logístico. 


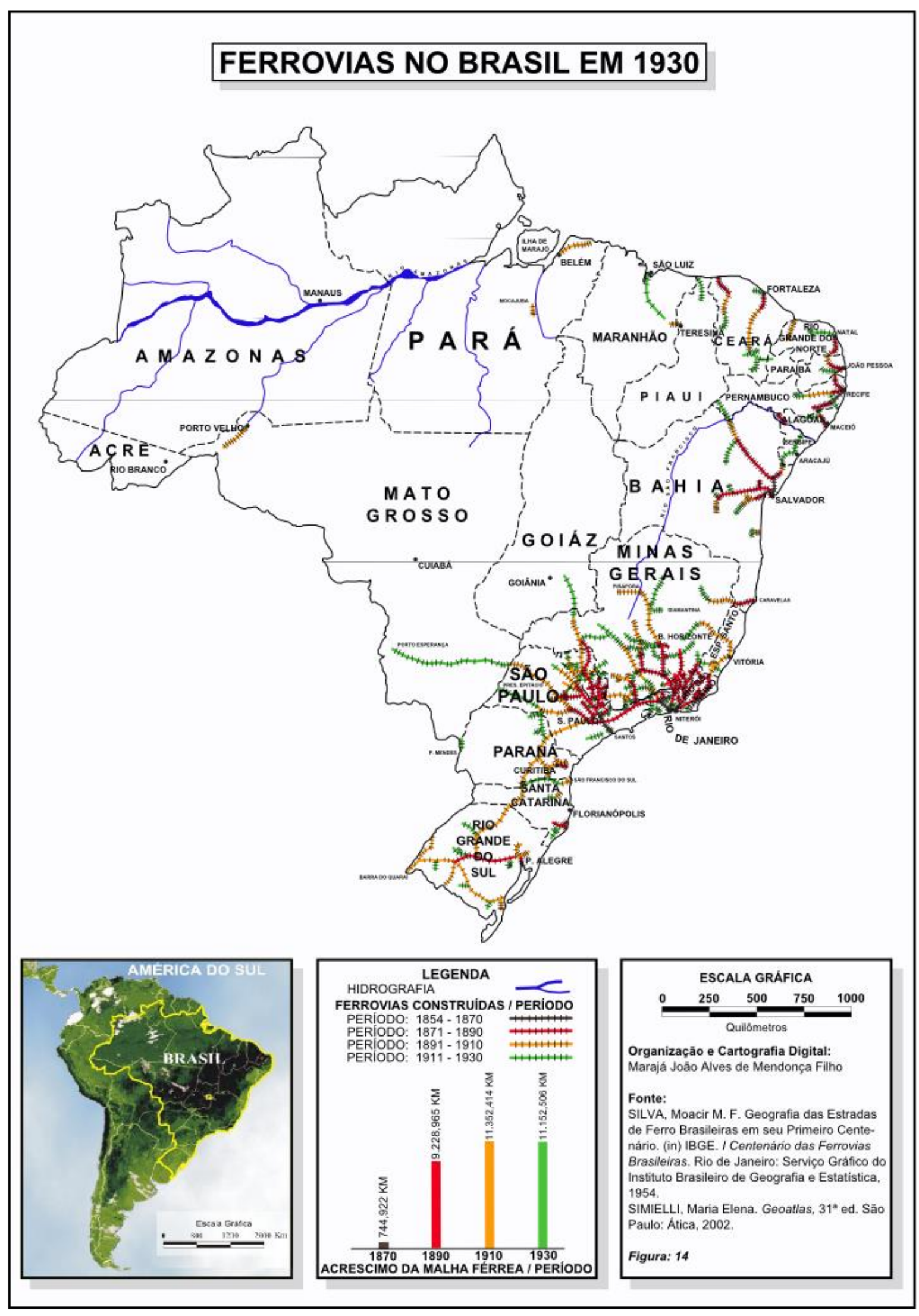


As regiões Norte e Centro Oeste ainda tinham uma parca quantidade de ferrovias, pelo fato de que os rios ali existentes conseguiam atender até certo ponto, algumas demandas em transportes. Outro aspecto a ser considerado foi a incapacidade momentânea destas áreas em atrair os investimentos necessários que justificassem a implantação de ferrovias tão extensas e capazes de integrar áreas mais distantes do litoral ao movimento econômico das regiões Sudeste, Nordeste e Sul.

Com a crise econômica mundial de 1929 e a desaceleração produtiva em todo o mundo, inclusive no Brasil, houve uma diminuição no ritmo de investimentos e inclusive, falta de demanda nos transportes de certas mercadorias que eram destinadas ao mercado exterior. Foi a crise do liberalismo econômico. Em decorrência disso, durante o governo Vargas houve a necessidade de grande intervenção estatal na estrutura férrea do país, com o processo de saneamento de ferrovias estrangeiras e nacionais, que estavam em má situação financeira. Tal ação foi realizada pela Inspetoria Federal de Estradas (IFE), órgão do Ministério de Viação e Obras Públicas.

Esta inspetoria deu origem posteriormente ao DNER e DNEF em 1941. Foi o início da política keynesiana, conhecida também como "Estado de Bem Estar Social" que se estabeleceria em todo o mundo em meados da Segunda Guerra Mundial. Nela o Estado assume o papel de provedor dos bens e serviços necessários à população. O presidente Vargas criou em seu governo um projeto de substituição de importações de produtos industrializados a partir da instalação de infraestruturas que permitissem a criação de indústrias no próprio Brasil.

O objetivo foi mudar sua matriz produtiva agrária exportadora, para um modelo mais moderno, e menos dependente tecnologicamente, uma vez que os produtos agrícolas possuem baixo valor agregado, enquanto que os produtos industrializados, têm grande valor. Além de diminuir a dependência externa brasileira, o Brasil conseguiria melhorar sua balança comercial e a sua imagem na economia e na política internacional. A criação de estatais como a Companhia Siderúrgica Nacional - CSN em Volta Redonda - RJ em 1941, e da Companhia de Mineração Vale do Rio Doce - CVRD em 1942, foram fundamentais para o surgimento da indústria de base no Brasil.

Para atender a demanda de transporte de minérios, a Companhia Vale do Rio Doce absorveu a Estrada de Ferro Vitória a Minas (construída a partir de 1903), sendo estatizada e modernizada para suportar o tráfego de minério de ferro de Itabira - MG até o porto de Vitória 
- ES. Posteriormente esse minério era levado de navio até o litoral carioca para ser processado em Volta Redonda (ANPF, 2014).

Segundo Santos e Silveira (2001: 175), “a produção da fluidez é o resultado do conflito e cooperações, acordos e negociações, sempre provisórios, entre o Estado e as empresas, na construção e negociações de grandes sistemas técnicos". Isso explica o fato de que embora os capitais privados no Brasil sejam os maiores responsáveis pelos investimentos em ferrovias, há momentos em que o Estado precisa atuar cooperando com o capital privado para a manutenção e funcionamento destes sistemas.

As modificações no meio técnico, científico e informacional cooperam para as constantes modificações nas demandas logísticas, seja em quantidade e também em localização. Desta forma, as políticas públicas estabelecidas pelo Estado, este valendo-se inclusive de parcerias com capitais internacionais, são importantes para regulamentar o setor, a fim de manter seu equilíbrio.

Sobre este assunto, Santos e Silveira (IBIDEM) complementa "a participação dos governos mundiais (organismos internacionais financeiros) é permanente, viabilizando os empreendimentos por meio de créditos ou impondo os próprios projetos de engenharia. $\mathrm{E}$ os fluxos ferroviários decorrem dessas dinâmicas". Por isso a crescente rede ferroviária brasileira sempre está vinculada aos importantes portos marítimos e fluviais, uma vez que boa parte das demandas são destinadas ao mercado internacional, e também, ao recebimento de produtos importados.

As novas ferrovias possibilitaram a integração dos transportes terrestres das Regiões Nordeste, Sudeste, Centro-Oeste e Sul do Brasil. Além da modernização econômica, as ferrovias possibilitaram o início da integração nacional. Foi possível viajar de trem desde o Rio Grande do Sul até Alagoas, passando por Santa Catarina, Paraná, São Paulo, Rio de Janeiro, Minas Gerais, Bahia e Sergipe. Ou ainda, deslocar também para estados como Mato Grosso, Goiás e Espírito Santo, todos interligados na rede ferroviária nacional.

O papel do trem foi muito importante para o transporte de mercadorias e de pessoas, especialmente em locais onde não existia transportes navais e nem rodovias pavimentadas. Ressalta-se que em meados de 1954 várias ferrovias alcançavam países vizinhos, como a Bolívia, o Paraguai, a Argentina e o Uruguai. Entre os anos de 1930 e 1954 alguns fatos importantes se destacaram quanto a evolução tecnológica das ferrovias, como: a introdução da tração elétrica em alguns trechos em 1930, substituindo a vapor. A figura 15 mostra a situação da estrutura ferroviária brasileira em 1954. 


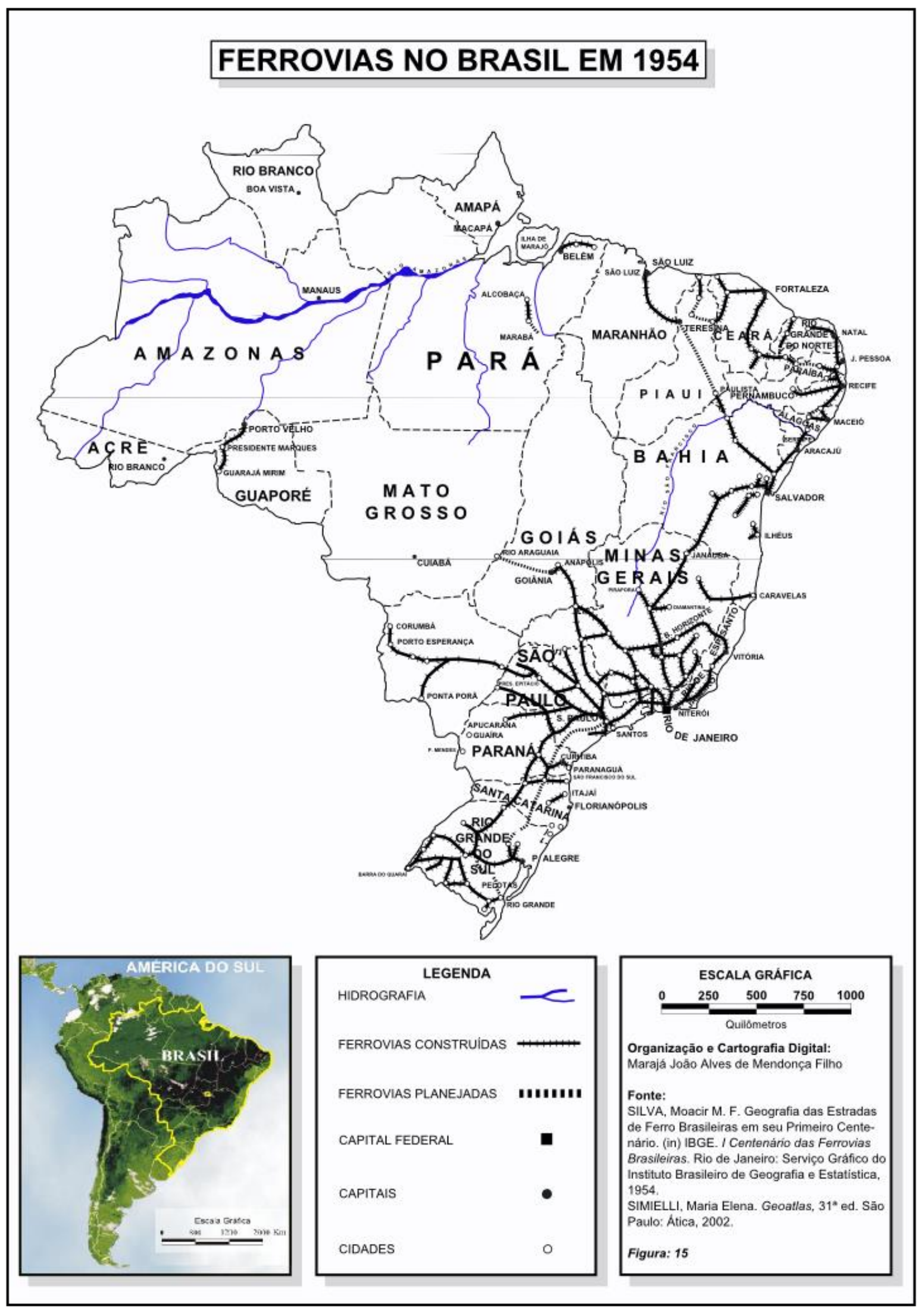


O início da substituição da tração a vapor pela diesel-elétrica em 1939, sendo foi interrompida durante a Segunda Guerra Mundial por falta de recursos. A partir da década de 1950 a substituição tecnológica foi novamente retomada e intensificada. Desta forma, observou-se que:

\begin{abstract}
Evidentemente em consequência de ter sido afinal estabelecido oficialmente, em 1934, um plano geral ferroviário (Plano Geral de Viação Nacional), aprovado pelo decreto $\mathrm{n}^{\circ}$ 24.497, de 19 de junho de 1934, que as construções de linhas férreas passaram a ter principalmente as "ligações ferroviárias", isto é, realizar a articulação das várias estradas, de forma a constituírem a grande rede ferroviária nacional (IBGE, 1954: 7).
\end{abstract}

Até 1952 o país atingiu mais de $37.000 \mathrm{~km}$ de ferrovias. No período compreendido entre 1931 a 1952, o Estado brasileiro assume o papel de planejador nacional dos transportes, ao invés de simplesmente "autorizador" da construção de ferrovias que eram feitas predominantemente pela iniciativa privada, tendo estatizado várias destas. Isso foi consequência direta de um contexto mundial pós Segunda Guerra, onde o Estado passa a planificar melhor a ocupação e o uso do território, com vistas a melhorar a segurança nacional. Essa política também era conhecida como Welfare State, termo sinônimo de Estado do Bem Estar Social.

Em 1950, o governo federal resolveu unificar as 18 Estradas de Ferro pertencentes à União, que totalizavam na época $37.000 \mathrm{~km}$, criar uma grande rede ferroviária estatal nacional. Em 16 de março de 1957 foi criada pela Lei $\mathrm{n}^{\circ}$ 3.115, a sociedade anônima Rede Ferroviária Federal S/A - RFFSA, com trilhos nas regiões NE, SE, CO e S do país. Tais trilhos passaram a funcionar de forma coordenada em todo o território e foram fundamentais para a ampliação da integração nacional. A partir de 1969 até 1974, as ferrovias da RFFSA foram agrupadas, para fins de gestão e operação, em quatro sistemas: Regional Nordeste, com sede em Recife; Regional Centro, com sede no Rio de Janeiro; Regional Centro Sul, com sede em São Paulo; e Regional Sul, com sede em Porto Alegre.

Com isso, em 1974 apenas cinco ferrovias não faziam parte da RFFSA: a Estrada de Ferro Amapá - AP, a Estrada de Ferro Madeira-Mamoré - RO, a Estrada de Ferro VitóriaMinas - ES-MG, a Estrada de Ferro Campos do Jordão - SP e a FEPASA (criada em 1971). Desde então, a integração das ferrovias permitiu viajar em quatro das cinco regiões brasileiras, sendo possível sair do Maranhão e chegar ao Rio Grande do Sul de trem. Passou a ser possível também chegar em países vizinhos com o Uruguai, a Argentina, o Paraguai e a Bolívia, aumentando a importância política e econômica do Brasil dentro da América do Sul. 


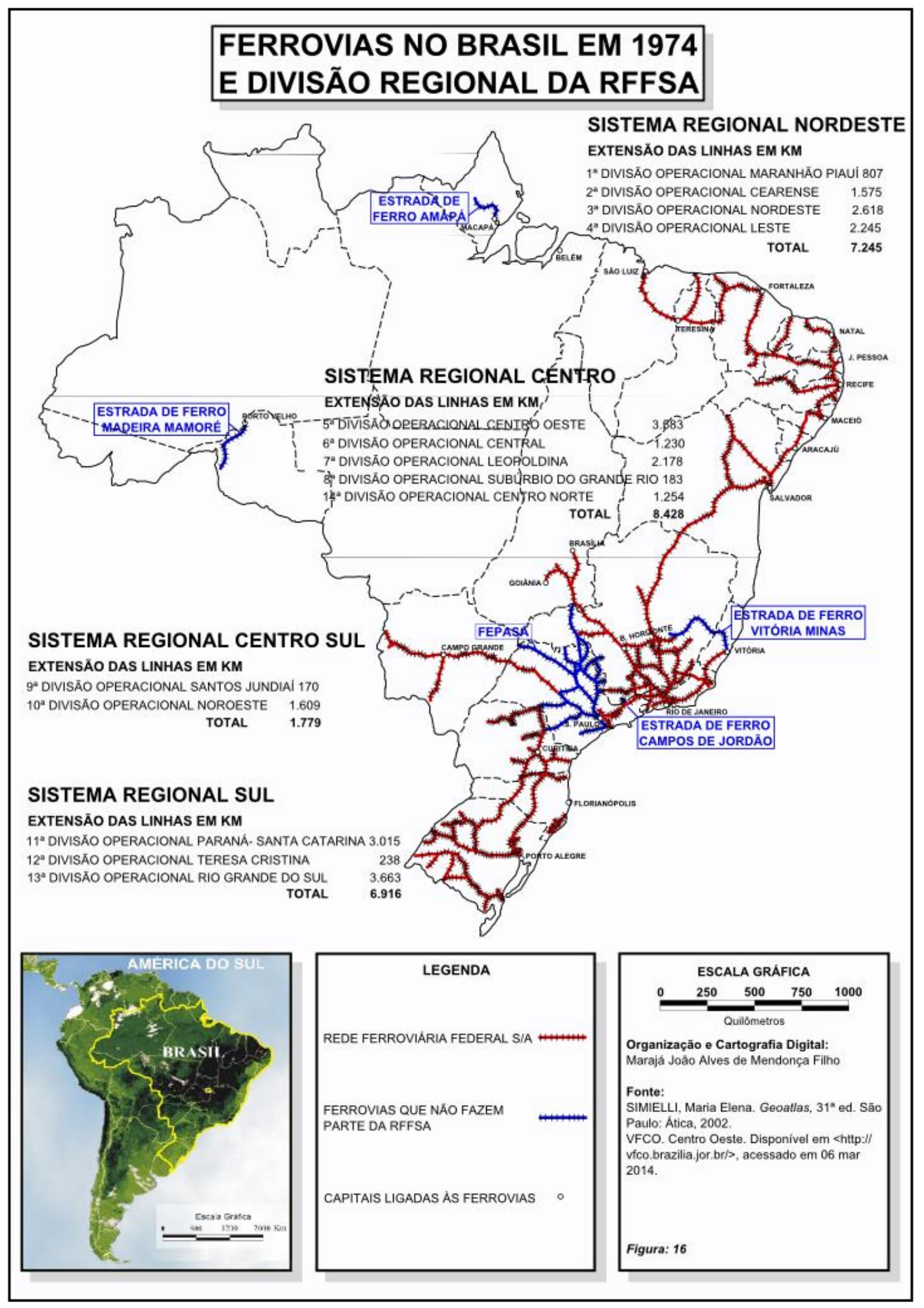


Ainda em 1974 o DNEF foi extinto e suas funções transferidas para a Secretaria Geral do Ministério dos Transportes e para a Rede Ferroviária Federal S/A - RFFSA. É preciso destacar que entre as décadas de 1950 e 1970 o Brasil passou ampliou a integração nacional, especialmente em decorrência da construção de Brasília e a transferência da capital federal do Sudeste para o Centro Oeste. Entretanto o modal de transportes que passou a predominar no país foi o rodoviário. Isso se deu principalmente em virtude dos Estados Unidos da América ter se transformado na maior potência mundial após a Segunda Guerra, substituindo a Inglaterra.

Assim, o modelo de transporte ferroviário, que é de predominância inglesa, aos poucos foi substituído pelo modelo rodoviário, de influência norte americana. Obviamente ao incentivar a construção de rodovias no Brasil, os EUA acabaram estimulando a criação de um enorme mercado consumidor para os fabricantes de automóveis do seu país.

Mesmo assim a estrutura ferroviária nacional era considerável, e para melhor controlar tamanha rede, em 1976 foram criadas pela RFFSA as Superintendências Regionais - SR, em número de 10 , posteriormente ampliadas para 12, cuja administração central localizava-se no Rio de Janeiro. Mais tarde, em decorrência de novas modificações nos transportes terrestres brasileiros houve alterações na divisão regional da RFFSA em 1984, com vistas ao enxugamento de custos, passando a constituir-se de apenas 7 Superintendências Regionais e uma Divisão Operacional.

A primeira SR era sediada em Recife e abrangia os estados do Maranhão, Piauí, Ceará, Rio Grande do Norte, Paraíba, Pernambuco e Alagoas. A segunda SR era sediada em Belo Horizonte e era composta pelos estados de Minas Gerais, Goiás, Rio de Janeiro, São Paulo e Distrito Federal. A Superintendência Regional 3 era sediada em Juiz de Fora e composta pelos estados do Rio de Janeiro, Minas Gerais, Espírito Santo e trecho de São Paulo.

A quarta Superintendência Regional era sediada em São Paulo e composta pelos estados de Mato Grosso do Sul e parte de São Paulo. A Superintendência Regional 5, que era sediada em Curitiba era composta pelos estados do Paraná e parte de Santa Catarina; a Superintendência Regional 6 era sediada em Porto Alegre e composta pelos estados do Rio Grande do Sul e parte de Santa Catarina. Completam a subdivisão da RFFSA em 1984, a Superintendência Regional 7 sediada em Salvador e composta pelos estados da Bahia, Sergipe, norte de Minas Gerais e trechos de Pernambuco. A figura 17 mostra como ficou a divisão da Rede Ferroviária Federal em 1984, incluindo a Divisão Operacional de Tubarão. 


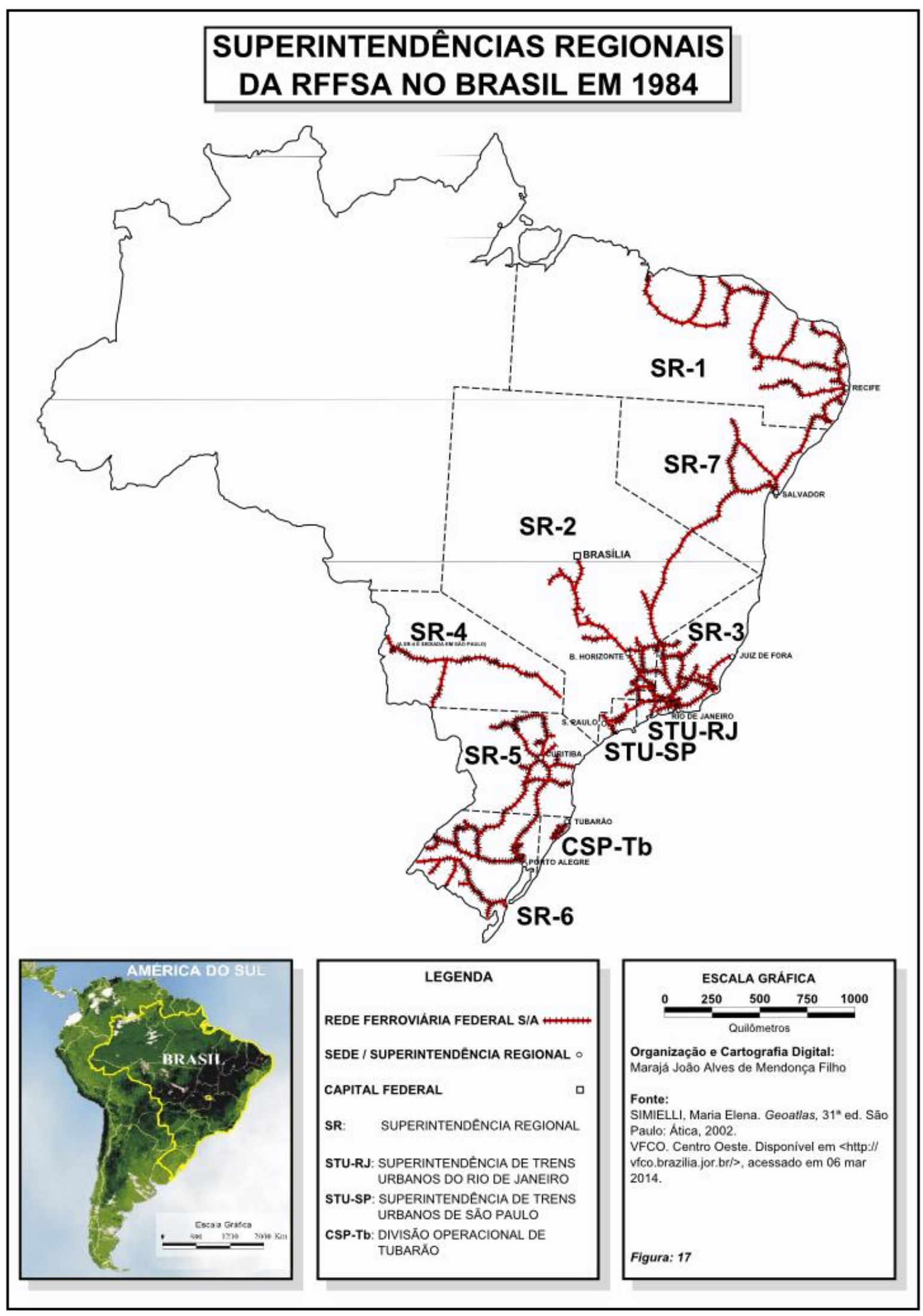


A Divisão Operacional de Tubarão era composta por $175 \mathrm{~km}$ de ferrovias que davam acesso ao respectivo porto, além da Superintendência de Trens Urbanos do Rio de Janeiro (STU/RJ). Tais linhas atendiam ao transporte de massa da Região Metropolitana da citada capital. Já a Superintendência de Trens Urbanos de São Paulo (STU/SP) foi destinada ao controle das linhas que atendiam ao transporte de massa da Grande São Paulo.

Estas divisões regionais em superintendências foram feitas para melhorar a gestão da rede e estabelecer uma boa gestão dos serviços desenvolvidos. Destaca-se a concentração férrea nos estados litorâneos e poucas são as vias que estão situadas nos estados interiores. Tal formatação expressa pois as hierarquias da rede ferroviária, seus arcos e os seus nós. Ou seja, os comandos das superintendências, estão localizados nas principais capitais brasileiras excetuando-se a divisão de Tubarão - com a missão de coordenar a logística férrea nacional, nas diversas regionais.

Isso é fruto das políticas de ocupação territorial do país, que seguiram sempre o sentido do litoral para o interior, em um movimento de continuidade executando principalmente nos governos Vargas (décadas de 1930 e 1940), Juscelino Kubistchek - JK (1950 e 1960) e Militares (1964 - 1984). Com Vargas iniciou-se a integração nacional, continuada pela transferência da capital federal e a construção de ferrovias ligando Brasília à todas as regiões do Brasil, e posteriormente a ocupação da Amazônia intensificada pelos militares. Percebe-se cada vez mais a preferência pelo automóvel em função da sua versatilidade para o transporte de pessoas e pequenas quantidades de cargas, sobretudo em locais distantes aos trilhos.

A valorização da rede rodoviária acabou criando uma competição com a rede ferroviária que passou a ser cada vez mais preterida, especialmente por não conseguir atingir localidades onde os carros chegavam. Isso gerou perdas nos serviços ferroviários, e justificou a desativação de vários ramais que passaram a ser antieconômicos. Várias cidades foram prejudicadas e outras beneficiadas. Além disso, as dificuldades financeiras vividas pelo Brasil nos anos 1980 provocaram cortes no orçamento da RFFSA, que reorganizou suas SR com o objetivo de melhorar a gestão.

Em 1991, época que marca o início do neoliberalismo no Brasil, a RFFSA foi reorganizada em 12 superintendências regionais, assumindo uma configuração muito parecida com a de 1965, excetuando-se os trilhos erradicados. De acordo com o neoliberalismo, o Estado deixa de ser o provedor para ser o regulamentador e fiscalizador dos serviços, e em nosso caso, dos transportes ferroviários. Os Anexos 2 e 3 detalham a nova divisão. 


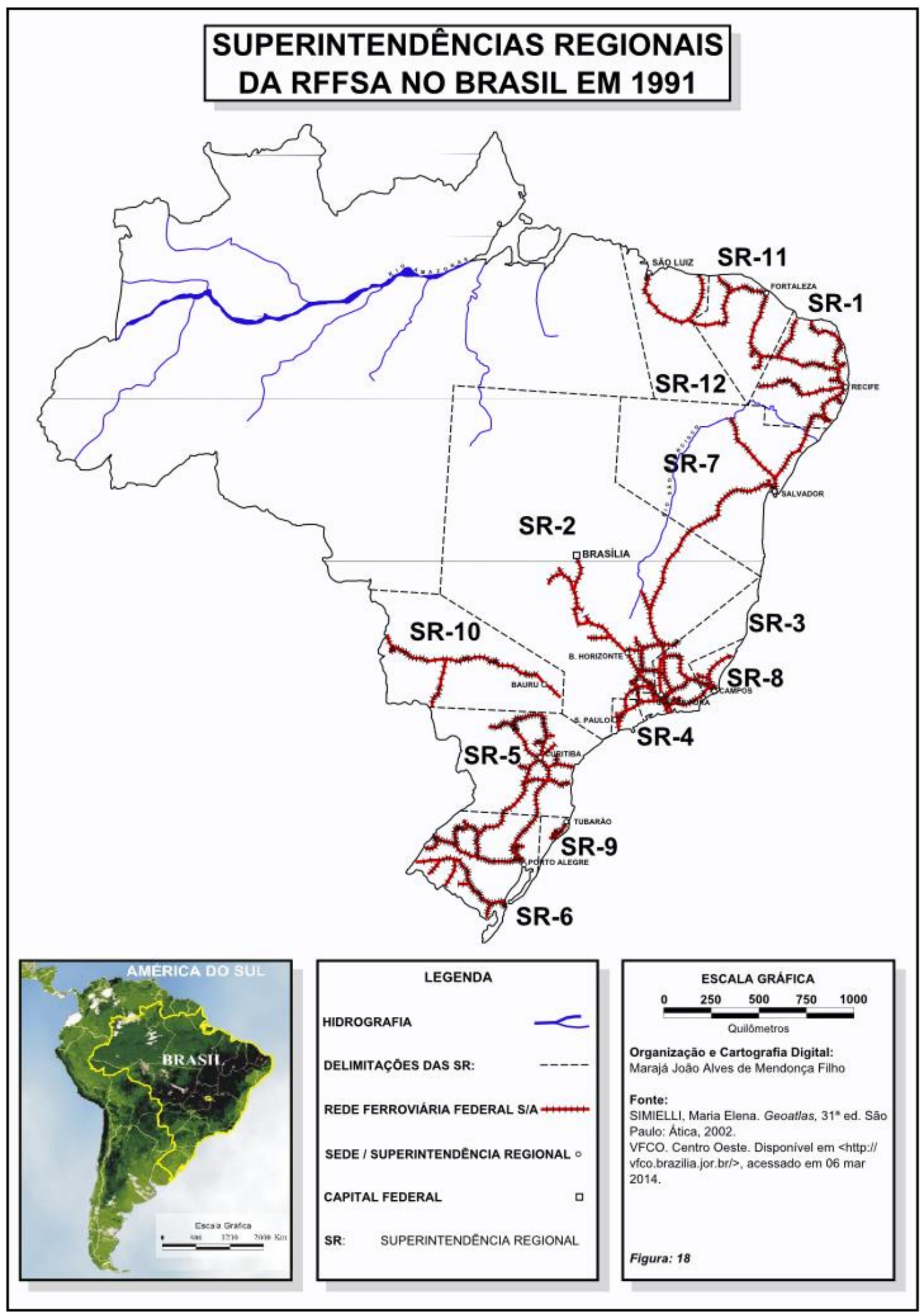


Cada superintendência subordinava-se diretamente à presidência da empresa. Todavia, com a constante expansão das rodovias, mais ferrovias foram aos poucos sendo desativadas. A Estrada de Ferro Santa Catarina foi erradicada em 1972 por causa dos déficits acumulados nos últimos anos da sua existência. Já a Estrada de Ferro Madeira-Mamoré teve sua desativação determinada em 1966 pelo presidente Castelo Branco, sendo reduzida a alguns quilômetros em 1970 e desativada definitivamente em 1972. Em 1981 um trecho de 7 quilômetros da Madeira-Mamoré foi reativado para fins turísticos e novamente paralisada em 2000.

A crise ferroviária atingiu também as ferrovias paulistas, que possuíam os maiores fluxos de transportes em decorrência da sua produção agropecuária e industrial. O resultado foi a união das ferrovias paulistas feita pelo governo do Estado de São Paulo. Em novembro de 1971, pela Lei 10.410 / SP a FEPASA foi criada, unificando em uma só empresa as cinco estradas de ferro de sua propriedade, que juntas totalizavam aproximadamente $5.000 \mathrm{~km}$ de vias férreas. Eram elas: Companhia Paulista de Estradas de Ferro; Estrada de Ferro Sorocabana; Estradas de Ferro Araraquara; Companhia Mogiana de Estradas de Ferro; e Estrada de Ferro São Paulo - Minas (ANTT, 2013).

É preciso lembrar que após alcançar seu tamanho máximo na década de 1940, as ferrovias paulistas iniciaram uma fase de recessão, em grande parte derivada da diversificação econômica do país e, consequentemente, do declínio da economia cafeeira. As rodovias construídas no Brasil até 1920 não alteraram os serviços prestados pelas ferrovias. Entretanto, após a Segunda Guerra Mundial (1939-1945) iniciou-se uma progressiva substituição das ferrovias pelas rodovias, enquanto matriz de transporte no Brasil, revelando uma clara prioridade à indústria automobilística que se consolidaria no mandato do presidente Juscelino Kubitschek (1956-1961) (ARQUIVO PÚBLICO DO ESTADO DE SÃO PAULO, 2014).

Por isso as ferrovias praticamente estagnam-se enquanto que as rodovias passaram por um forte processo de expansão, redesenhando a geografia dos transportes no país, e mantendo a concentração da rede férrea no Sudeste brasileiro, em especial, no estado de São Paulo. Tal concentração foi responsável inclusive pela criação da estatal de nível estadual responsável por boa parte das ferrovias situadas em solo paulista.

Portanto, a empresa Ferrovia Paulista S.A - FEPASA, é o resultado de um demorado processo de estatização das ferrovias em São Paulo que começaram a dar prejuízos aos seus antigos proprietários. Tal processo iniciou-se em 1919 com a incorporação da Estrada de Ferro Araraquara e da Estrada de Ferro Sorocabana à gestão estatal (IBIDEM). 
Assim, a criação da FEPASA foi fruto da necessidade de sanear as ferrovias que passavam por problemas financeiros em função da paulatina mudança do modal ferroviário para o rodoviário, e também, pela diversificação dos produtos produzidos, que aos poucos substituem a monocultura do café. A diversificação representou menores volumes de cargas distintas, cada qual com destinos diferentes, o que contrastou com o café, que era praticamente todo levado para o porto de Santos. Por isso, os caminhões ganharam espaço no transporte das mercadorias diversificadas. Com a FEPASA, as ferrovias ganharam novo fôlego e passaram por nova formatação administrativa, tentando se adequar ao novo contexto.

A criação da FEPASA foi resultado de um longo processo de reajuste administrativo e financeiro, pois aos poucos as ferrovias paulistas passaram a acumular a gestão umas das outras. Tais reajustes ocorreram em função de vários fatores, em especial, a quebra da bolsa de Nova York em 1929, o que trouxe consequências para a economia brasileira. Deste modo, as ferrovias entram em crise financeira e passam por um paulatino processo de estatização.

Em 1929 a Estrada de Ferro São Paulo-Minas declara falência por causa da má administração de seus proprietários. Por isso, o estado de São Paulo assume a ferrovia em 1930, retomando a normalidade das suas operações no ano seguinte. Na década de 1950 as dificuldades financeiras das empresas ferroviárias alcançaram outras corporações, de modo que atingisse a Companhia Mogiana de Estradas de Ferro. Esta acabou também passando às mãos do Estado de São Paulo, no ano de 1952.

Em 1961 as crises vividas pela Companhia Paulista de Estradas de Ferro levaram ao mesmo processo, contando, nesse caso, com enorme pressão exercida pelos trabalhadores em prol da encampação pública. Nesse período foi realizado um estudo pelo Instituto de Engenharia de São Paulo sugerindo a formação da Rede Ferroviária Paulista. Por isso, projetos são enviados à Assembleia Legislativa do Estado em 1962, 1966 e 1971. Segundo dados do Arquivo Público do Estado de São Paulo (2014),

\footnotetext{
O último dos projetos acima é o responsável pela formação da FEPASA, oficializando algo que, na prática, já estava quase ocorrendo, visto que desde 1967 a São Paulo-Minas já estava sendo administrada pela Mogiana, e a Araraquara pela Companhia Paulista. Somadas à Sorocabana, formaram a FEPASA, contando, no ato de sua fundação, com aproximadamente 5 mil quilômetros de trilhos e aproximadamente 36 mil funcionários. A empresa funcionaria por 27 anos.
}

Inicialmente a FEPASA foi organizada em 8 Gerências Regionais. A figura 19 mostra o resultado da unificação destas vias e a posterior divisão regional. 


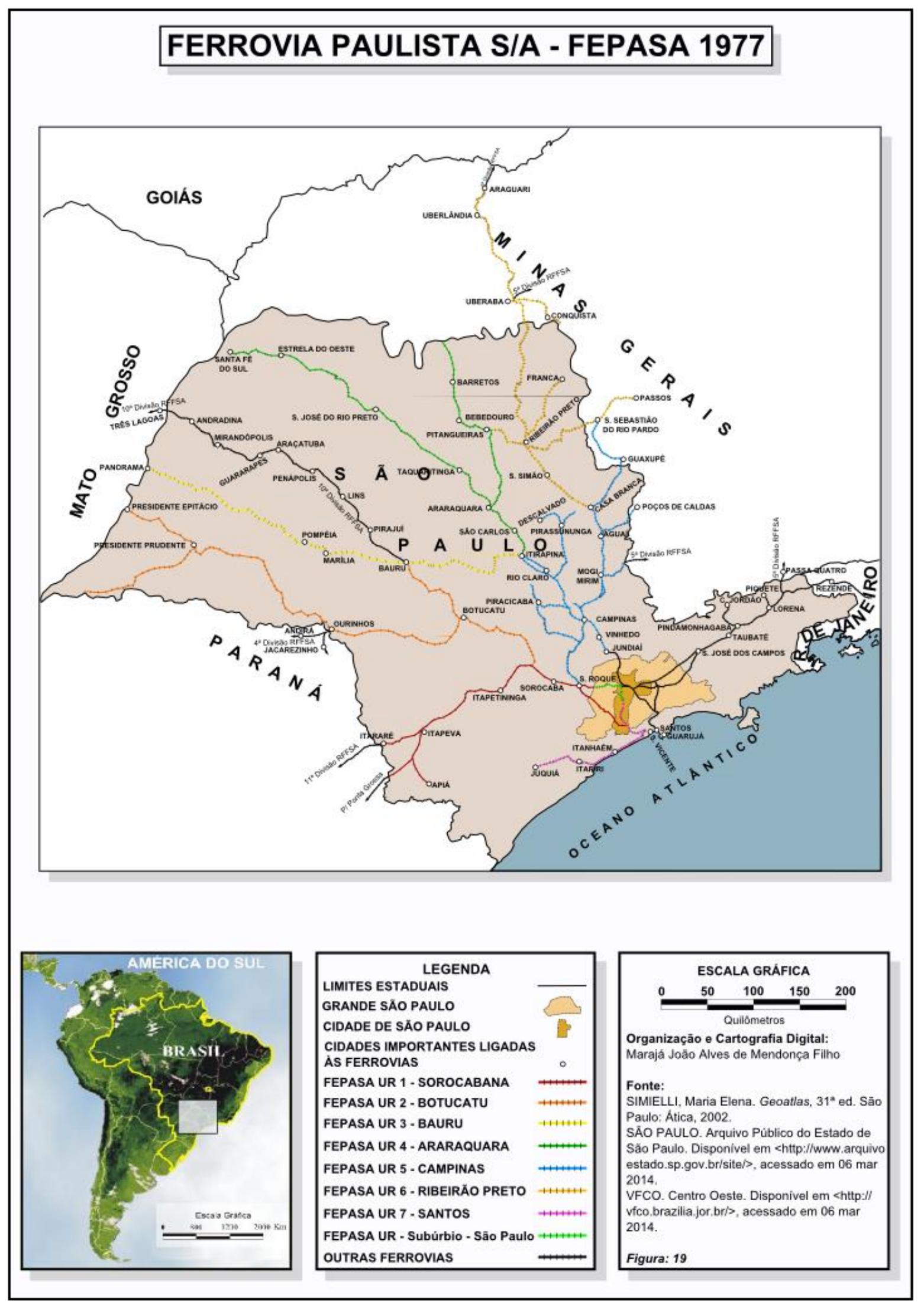


As Gerências Regionais foram sediadas em: Sorocaba (UR - 1) na cor vermelha, Botucatu (UR - 2) na cor laranja, Baurú (UR - 3) na cor amarelo claro, Araraquara (UR - 4) na cor verde, Campinas (UR - 5) na cor azul. Ribeirão Preto (UR - 6) na cor amarelo escuro, Santos (UR - 7) na cor rosa e São Paulo (UR - Subúrbio) na cor verde claro. As ferrovias da FEPASA eram dotadas de bitolas métrica (1,0 metro) simples e dupla, bitolas largas (1,6 metros) simples e dupla, bitola mista (1,0 e 1,6 metros) e eletrificada. Possuía, portanto, a maior variedade de bitolas (largura dos trilhos) do país.

O Estado de São Paulo torna-se dono de praticamente quase todas as ferrovias existentes em seu território, exceção feita a alguns trechos da RFFSA. As ferrovias ligavam os portos do litoral paulista, em especial, o de Santos à capital e à Região Metropolitana de São Paulo. De lá as ferrovias irradiam em vários sentidos, o interior do estado de São Paulo, além dos estados de Minas Gerais, Mato Grosso, Paraná e Rio de Janeiro.

As ferrovias que antes destinavam-se praticamente ao transporte do café passam a conduzir outros tipos de mercadorias. Segundo Santos e Silveira (2001: 175), "Nos albores da década de 1970, as ferrovias paulistas transportavam sobretudo milho, trigo e café, além de cimento, madeira, açúcar, adubos e fertilizantes". O transporte de passageiros também diversifica, sobretudo com o transporte em áreas urbanas, com destaque para a região da Grande São Paulo, atingindo em 1970 o total de 329,64 mil pessoas por dia.

Outra importante via conectada à rede da FEPASA é a ferrovia que em 1977 fazia parte da $10^{\text {a }}$ Divisão da RFFSA, iniciada na cidade de Bauru, interior paulista, a qual segue rumo ao Estado de Mato Grosso, até a cidade de Três Lagoas. De lá a ferrovia atravessa todo Mato Grosso até o Paraguai. É importante lembrar que o Estado de Mato Grosso do Sul foi criado apenas em 11 de outubro de 1977, no governo do presidente Ernesto Geisel.

A rede formada pela ferrovia mato-grossense e a FEPASA estabeleceu um grande corredor de negócios, ligando o Paraguai ao Oceano Atlântico, via porto de Santos. Outra importante ligação da FEPASA foi com a $5^{\text {a }}$ Divisão da RFFSA, a partir da Grande São Paulo rumo ao vale do Rio Paraíba do Sul, sentido São José dos Campos, atingindo os estados do Rio de Janeiro e Minas Gerais. A $5^{\text {a }}$ Divisão da RFFSA, Minas Gerais, também conectava a FEPASA nas URs Campinas e Ribeirão Preto, passando pelas cidades de Poços de Caldas, Guaxupé, São Sebastião do Rio Pardo, Uberaba e Conquista. A FEPASA conectava também às ferrovias paranaenses da RFFSA, especialmente a $4^{\mathrm{a}}$ Divisão, a partir da cidade de Ourinhos à UR Botucatu, e da $11^{\mathrm{a}}$ Divisão a partir das cidades de Itararé e Itapeva à UR Sorocaba. 
Após os 27 anos de existência, a FEPASA foi adquirida pela Rede Ferroviária Federal (RFFSA), passando a fazer parte dela a partir de 1998, e sendo vendida para a iniciativa privada no ano seguinte. Consolida a visão neoliberalista, uma vez que o serviço ferroviário brasileiro foi praticamente todo transferido para a iniciativa privada, e o Estado passa a regulamentar o serviço.

Esse processo é o resultado dos fatores econômicos e políticos ocorridos anteriormente. Em especial, destaca-se que no período de 1980 a 1992 os investimentos na RFFSA e na FEPASA foram afetados consideravelmente. Para se ter uma ideia, o total investido em 1989 correspondeu a apenas 19\% do total de 1980. Em 22 de fevereiro de 1984, o Governo Federal afastou a RFFSA dos transportes urbanos e criou a CBTU, buscando melhorar a logística dos transportes urbanos.

Para tentar resolver os problemas decorrentes da falta de investimentos nas ferrovias, o governo federal iniciou o processo de concessão das ferrovias à iniciativa privada. A retorno das ferrovias para a iniciativa privada ocorreu em função da política neoliberal implementada pelo governo federal na década de 1990, a partir da gestão do presidente Fernando Collor de Melo, visando diminuir as atribuições do Estado em relação aos transportes, em especial, o ferroviário.

Curiosamente, os fluxos de cargas nas ferrovias aumentaram bastante entre 1960 e 1990. Segundo Santos e Silveira (2001: 175), "De 44.846 toneladas em 1960, os fluxos passaram a 235.105 toneladas em 1990, isto é, houve um aumento de 5,2 vezes”. O transporte de passageiros também cresceu entre os anos de 1970 e 1994. De acordo com Santos e Silveira (IDEM: 176), “entre 1970 e 1994 o número de passageiros cresceu 3,5 vezes, passando de 329,64 mil para 1.163 .034 pessoas" por dia. Com relação aos fluxos de passageiros, isso deveu-se sobretudo ao aumento de transportes metropolitanos nos trens suburbanos e no metrô de São Paulo. Ainda segundo Santos e Silveira (IBIDEM), “em 1994 o fluxo do metrô paulistano representara 53,7\% do total nacional de passageiros sobre trilhos". Um verdadeiro fenômeno.

Mesmo assim, a rede ferroviária brasileira operava de forma deficitária. A modernização produtiva brasileira não foi acompanhada da devida adequação da rede ferroviária, principalmente quanto às interações regionais. Isso se deve principalmente às diferenças das bitolas que dificultavam o transbordo eficiente, e também ao próprio traçado das vias que ligam as regiões interioranas predominantemente aos portos, dificultando a solidariedade regional (SANTOS e SILVEIRA, 2001). 
O resultado foi a Lei 8.031 de 1990 e suas alterações posteriores, que instituíram o Programa Nacional de Desestatização - PND, sendo a RFFSA incluída em 10 de março de 1992, por meio do decreto 473. O BNDES atuou como gestor de todo o processo, conforme o Decreto $n^{\circ} 1.024$ de 1994. O processo de desestatização da RFFSA foi realizado com base na Lei no 8.987 de 1995 (Lei das Concessões), e seguiu a seguinte cronologia:

Quadro 1 - Cronologia do Processo de Desestatização da RFFSA.

\begin{tabular}{|l|c|l|c|c|}
\hline \multicolumn{1}{|c|}{ Malhas Regionais } & $\begin{array}{c}\text { Data do } \\
\text { Leilão }\end{array}$ & \multicolumn{1}{|c|}{ Concessionárias } & $\begin{array}{c}\text { Início da } \\
\text { Operação }\end{array}$ & $\begin{array}{c}\text { Extensão } \\
\text { Km }\end{array}$ \\
\hline OESTE & $05 / 03 / 1996$ & Ferrovias Novoeste S/A & $01 / 07 / 1996$ & 1.621 \\
\hline CENTRO-LESTE & $14 / 06 / 1996$ & Ferrovia Centro Atlântica S/A & $01 / 09 / 1996$ & 7.080 \\
\hline SUDESTE & $20 / 09 / 1996$ & MRS Logística S/A & $01 / 12 / 1996$ & 1.674 \\
\hline TERESA & $22 / 11 / 1996$ & Ferrovia Teresa Cristina S/A & $01 / 02 / 1997$ & 164 \\
\hline CRISTINA & $18 / 07 / 1996$ & $\begin{array}{l}\text { Companhia Ferroviária do } \\
\text { Nordeste }\end{array}$ & $01 / 01 / 1998$ & 4.534 \\
\hline SURDESTE & $13 / 12 / 1998$ & $\begin{array}{l}\text { Ferrovia Sul Atlântico S/A, } \\
\text { atual ALL - América Latina } \\
\text { Logística }\end{array}$ & $01 / 03 / 1997$ & 6.586 \\
\hline PAULISTA & $10 / 11 / 1998$ & Ferrovia Bandeirante S/A & $01 / 01 / 1999$ & 4.236 \\
\hline TOTAL & \multicolumn{3}{|l}{} & $\mathbf{2 5 . 8 9 5}$ \\
\hline
\end{tabular}

Fonte: RFFSA e BNDES apud ANTT (2013).

Em pouco mais de três anos foi concluído o processo de desestatização das ferrovias no Brasil. Ressalte-se que com o leilão da Malha Paulista (antiga FEPASA incorporada a RFFSA pelo Decreto 2.502 de 18/02/98), concluiu-se o processo de desestatização das malhas da RFFSA.

Em 18 de junho de 1997, o Governo Federal outorgou à Companhia Vale do Rio Doce no processo da sua privatização, a E.F. Vitória a Minas e a E.F. Carajás, responsáveis pelo transporte de $40 \%$ e 18,4\% respectivamente do total de cargas ferroviárias de todo o Brasil no referido ano. Em 07 de dezembro de 1999, o Conselho Nacional de Desestatização e por intermédio do Decreto $\mathrm{n}^{\circ}$ 3.277, dissolveu, liquidou e extinguiu a RFFSA (ANTT, 2013).

Observa-se a criação de várias empresas privadas que passaram a controlar partes da malha ferroviária nacional. Dentre as principais medidas tomadas por elas destacaram-se: a identificação de trechos antieconômicos com a respectiva desativação destes; o fim do transporte de passageiros em quase todas as ferrovias e a consequente desativação da maioria das estações; o direcionamento das ferrovias para o transporte de cargas de grande quantidade agregada e com menor diversidade de produtos, especialmente minérios e grãos. Excetuando se as ferrovias que passaram para o controle da Companhia Vale do Rio Doce, como a Estrada de Ferro Carajás e a Estrada de Ferro Vitória - Minas, e as ferrovias do grupo VALEC. As 
demais estão sobre controle privado. O novo arranjo ferroviário brasileiro após as privatizações ficou da seguinte forma:

Figura 20 - Principais ferrovias brasileiras após a privatização.

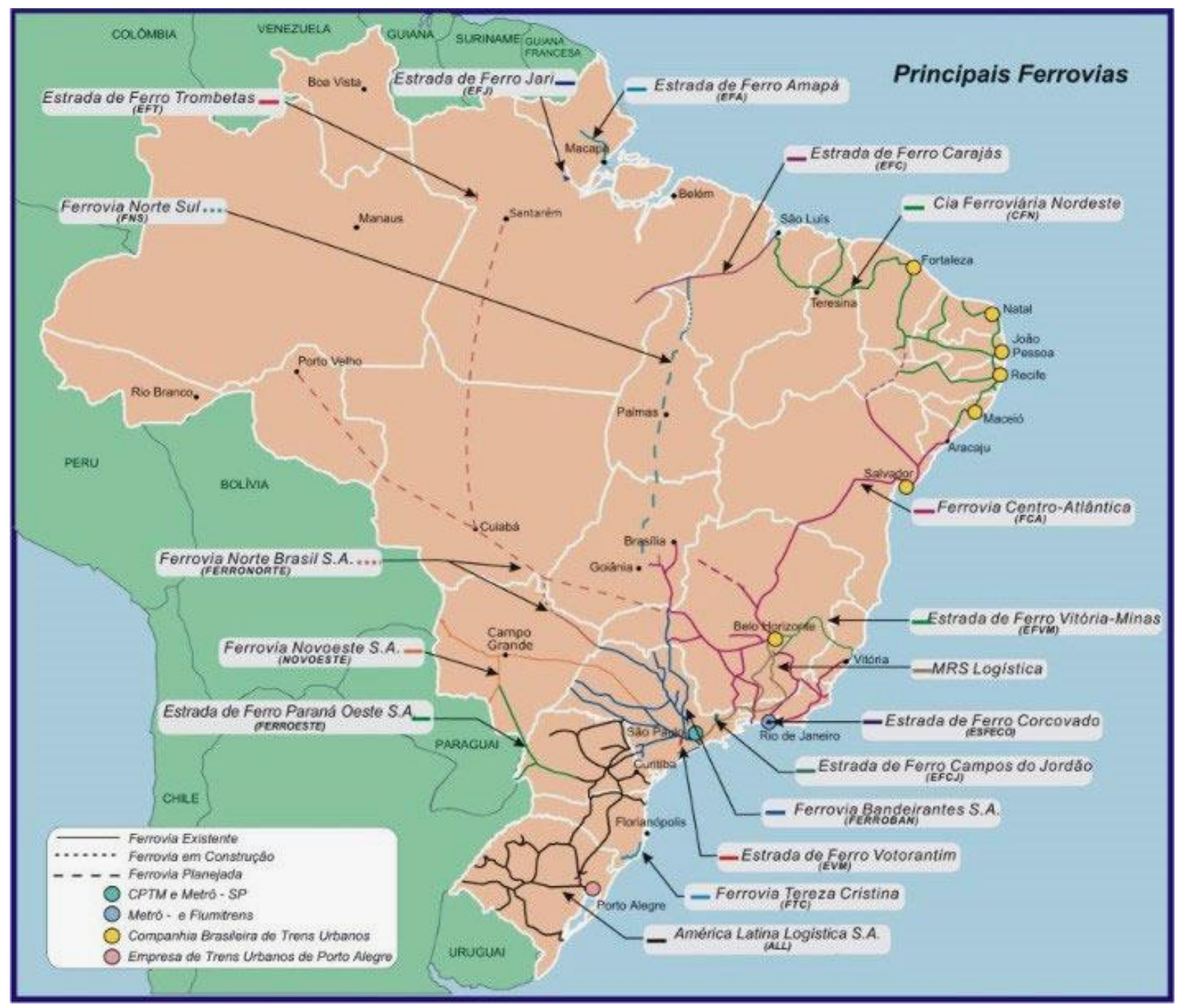

Fonte: UNIVERSO LOGÍSTICO, 2014.

Em 2000, um ano após o fim da privatização da rede ferroviária brasileira, 21,6 \% do transporte nacional foi feito por ferrovias. Dez anos depois, como fruto das medidas de ajuste no setor o percentual de transporte via ferrovias subiu para $25 \%$. Por outro lado, o transporte rodoviário de cargas no mesmo período diminuiu de $63,8 \%$ para 56,8\% do total nacional. O transporte aquaviário também teve aumento, passando de $14,4 \%$ para $18,1 \%$ no referido período. De qualquer forma o transporte ferroviário de cargas manteve-se na segunda colocação quanto ao total de cargas transportadas no país.

Com relação ao transporte de passageiros, excetuando-se as redes ferroviárias urbanas, atualmente existem apenas três trens em funcionamento no país: A Estrada de Ferro Vitória - 
Minas (ES / MG), ligando a cidade de Belo Horizonte a Vitória, com 664 km de extensão; A Estrada de Ferro Carajás, ligando as cidades de Parauapebas - PA e São Luís - MA, com 892 km; e a Estrada de Ferro Curitiba / Morretes / Paranaguá - PR, com 110 km de extensão. O gráfico 2 mostra os percentuais da evolução do transporte de cargas por modal.

Gráfico 2 - Evolução do Transporte de Cargas no Brasil entre 1970 e 2010.

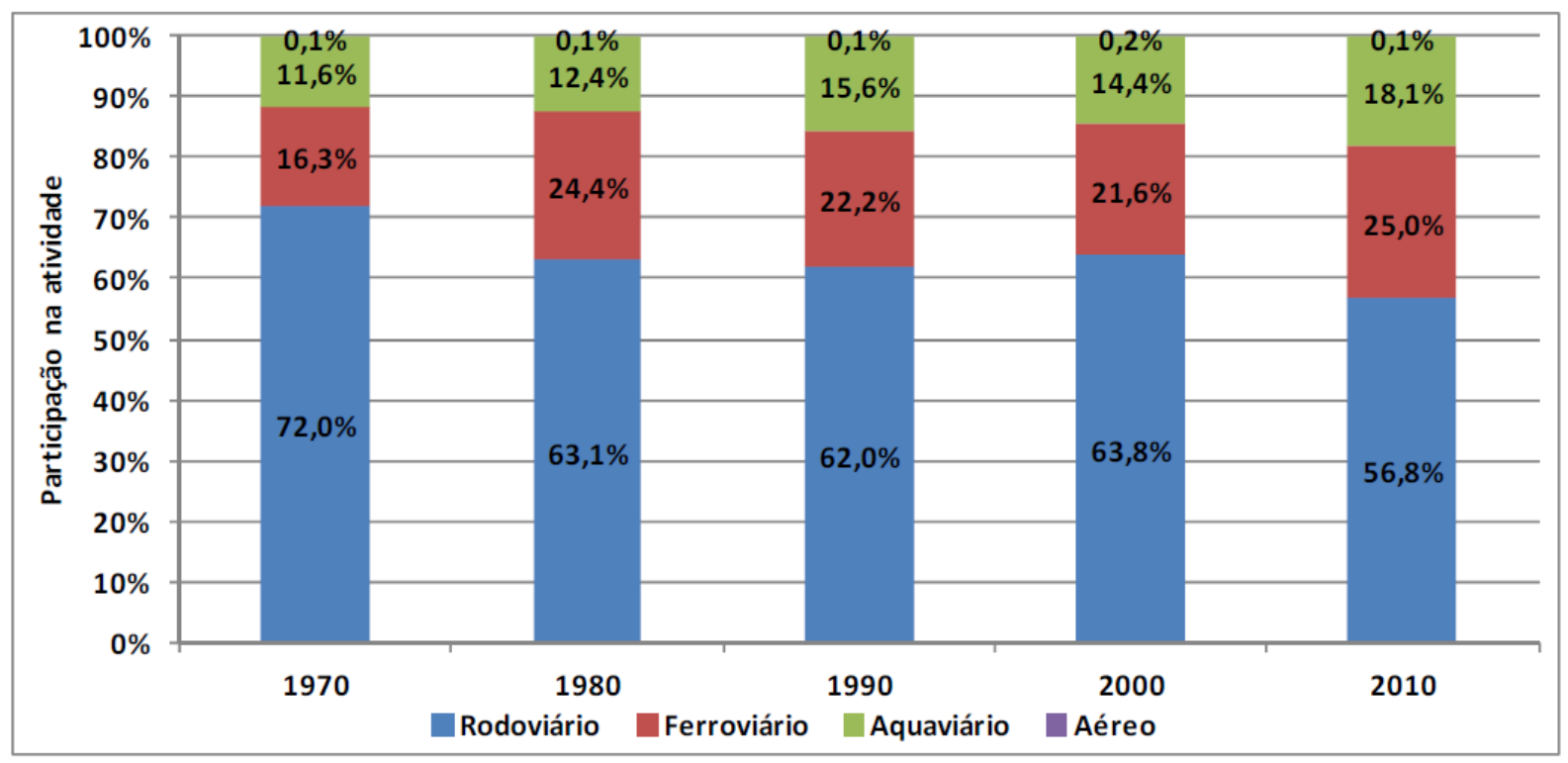

Fonte: Consolidação de Bases de Dados do Setor de Transporte 1970 - 2010. Ministério de Minas e Energia (2012)

Mesmo considerando a soma dos transportes de passageiros das redes urbanas com as demais ferrovias que transportam passageiros no Brasil, os índices caíram consideravelmente de 1970 para 2010 , diminuindo de $9,7 \%$ para $1,7 \%$ respectivamente no período. Por outro lado, considerando o período de 2000 para 2010, houve ligeira melhora de 1,5\% para 1,7\%, graças sobretudo à expansão dos transportes sobre trilhos nas regiões metropolitanas do país.

Já o transporte rodoviário que em 1970 foi responsável por $86,8 \%$ do total, subiu em 2000 para 93,5\% e em 2010 teve ligeira queda para 92,2\%. Por outro lado, o transporte aéreo que em 1970 representou 3,3\% do total nacional, em 2000 alcançou 5\%, e em 2010 atingiu $6 \%$. Isso mostra que o transporte ferroviário que chegou a ser o segundo mais usado no Brasil em 1970 passou a terceiro em 2000 e manteve-se nessa posição em 2010, perdendo para os modais rodoviário e aeroviário. Há uma tendência da diminuição de transporte no modal rodoviário e aumento nos modais ferroviário e aquaviário. Embora os capitais privados tenham focado na melhoria do setor ferroviário com consequente melhora no transporte de cargas, o mesmo não se pode dizer do transporte de passageiros. O gráfico 3 mostra os percentuais dos transportes de passageiros no Brasil por modal. 
Gráfico 3 - Evolução do Transporte de Passageiros no Brasil entre 1970 e 2010.

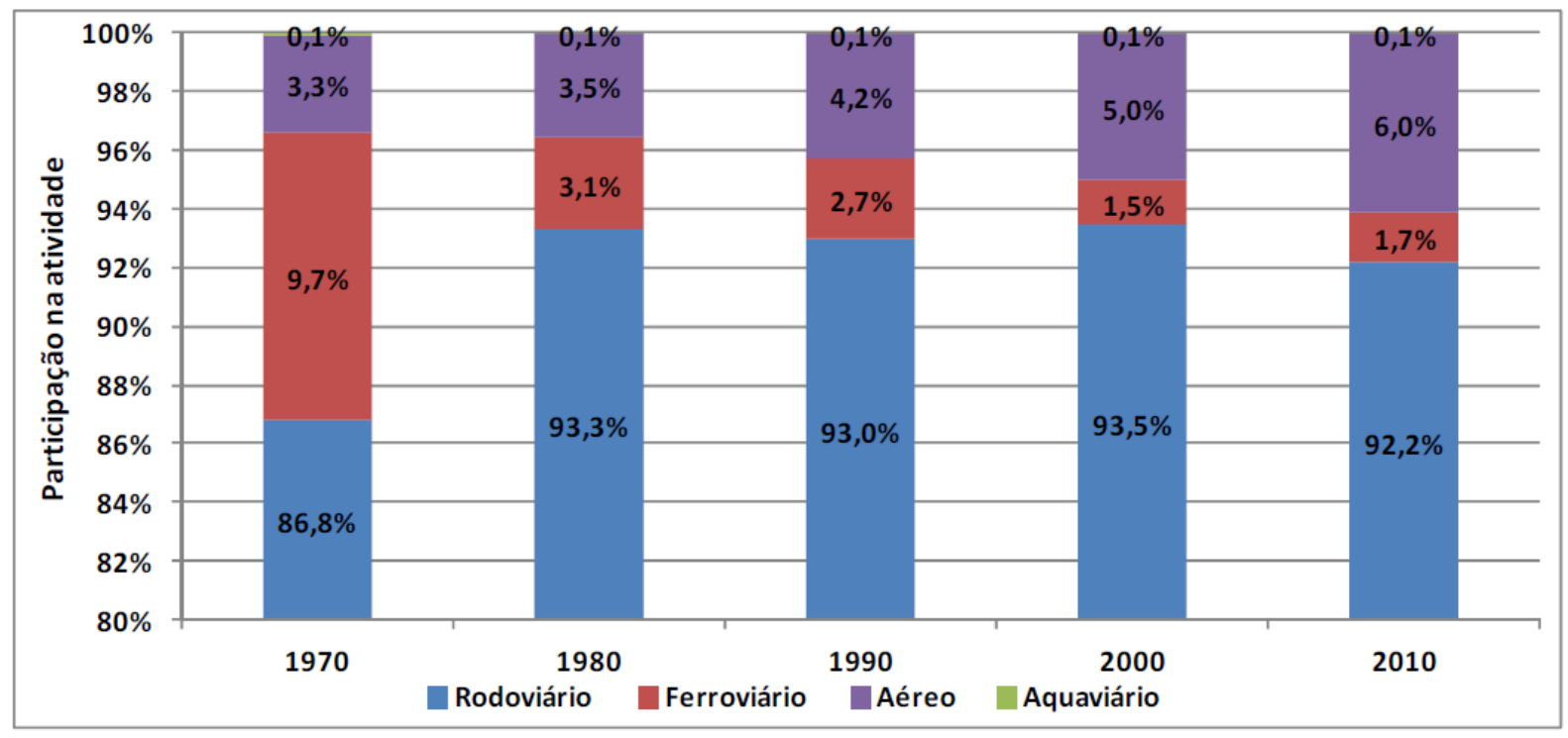

Fonte: Consolidação de Bases de Dados do Setor de Transporte 1970 - 2010. Ministério de Minas e Energia (2012)

Outro aspecto que se destaca é a concentração das malhas ferroviárias seguindo um padrão de concentração nas áreas litorâneas, especialmente nas regiões mais produtivas do Sudeste, Nordeste e Sul do Brasil. Tais malhas aos poucos adentraram o território permitindo a expansão da produção em áreas até então não alcançadas por certos tipos de atividades econômicas e culturas agrícolas em função da dificuldade em transportá-las até os centros consumidores. Assim, o crescimento da rede ferroviária nacional expressa a apropriação e a dinamização econômica do território desde o final do século XIX até a primeira metade do século XX, quando são paulatinamente relegadas a um segundo plano por causa da expansão rodoviária. A tendência é de manutenção do percentual no modal rodoviário, diminuição no ferroviário e aumento no aéreo. Tais mudanças refletiram na infraestrutura logística do Estado de Goiás que também passou por transformações. 


\section{GOIÁS NO CENÁRIO DE INTEGRAÇÃO NACIONAL E O PAPEL DO TRANSPORTE FERROVIÁRIO ${ }^{6}$}

Neste capítulo abordaremos as transformações econômicas e geográficas ocorridas com a chegada das ferrovias em Goiás. Inicialmente analisaremos a situação de Goiás antes das ferrovias e as contribuições das Estradas de Ferro Mogiana e Goiás. Em seguida analisar-se-á a construção de Goiânia no cenário da marcha para o oeste. Por fim, será analisado o avanço das frentes pioneiras no Estado.

Para atingir os objetivos propostos será analisado o histórico da implantação das primeiras ferrovias em Goiás, a análise do processo paulatino de avanço dos trilhos e a compreensão da Marcha para o Oeste enquanto estratégia de avanço da fronteira econômica. A partir do período de 1945 a 1964, com o fim da $2^{\text {a }}$ Guerra Mundial e a reestruturação da liderança na nação, outras modificações foram feitas, em especial a incorporação econômica das terras do Brasil Central. As frentes pioneiras que avançaram sobre Goiás, vindos, sobretudo do Sudeste brasileiro utilizaram as ferrovias existentes com via para a incorporação de novas áreas agricultáveis.

Enfim, observa-se que na medida em que as áreas menos adensadas demograficamente do país foram paulatinamente apropriados pelo capital, foi necessário adequar as vias de circulação para o crescimento econômico da nação. Ressalta-se que a busca desse adensamento populacional em áreas até então pouco povoadas do território nacional foi estimulado pelo Estado, visando a geopolítica de segurança nacional, uma vez que várias invasões em territórios estrangeiros ocorreram durante os conflitos mundiais do século XX. Esses conflitos foram provocados pelas políticas expansionistas de alguns Estados Nacionais europeus em busca do aumento do território, e consequentemente, do aumento do Poder Nacional.

\subsection{A FERROVIA MOGIANA NA INTEGRAÇÃO DE GOIÁS COM O SUDESTE}

Neste tópico, será feito um resgate histórico sobre as ferrovias goianas com maior nível de detalhes. Alguns aspectos da formação territorial do Brasil serão ressaltados e os contextos

\footnotetext{
${ }^{6}$ Trechos deste capítulo foram baseados e ou retirados da minha dissertação de mestrado intitulada "Influências Geopolíticas e Defesa Nacional: quartéis do Exército nas áreas de cerrado de Goiás, Tocantins, Distrito Federal e Triângulo Mineiro, defendida em 2005, na Universidade Federal de Goiás, sob a orientação da Profa. Dra. Maria Geralda de Almeida.
} 
econômicos e geopolíticos serão analisados. Sabe-se que próprio Brasil, e consequentemente Goiás, historicamente surgiram do aumento dos territórios sob o comando português. Isso é bem evidente quando se analisa o cenário das estratégias geopolíticas das grandes potências europeias no final do século XIV, e posteriormente entre os séculos XV a XVIII. A política expansionista de Portugal, sempre buscou o aumento territorial do Brasil, como forma de aumentar a renda da Coroa, e constituir um "fundo de reserva" em riquezas naturais para futuras explorações (BECKER, 1998). Neste sentido, a União Ibérica ${ }^{7}$ foi extremamente favorável à expansão portuguesa além Tordesilhas, já que todos os territórios das colônias ibéricas passaram a pertencer tanto a Portugal quanto à Espanha.

Este avanço significou para o Brasil um aumento no tamanho do seu território, de forma que o atual "contorno" do país foi praticamente definido com base nestas ocupações. Com o fim da União Ibérica, Portugal adiciona os territórios que explorava em áreas espanholas, o que aumentou a colônia portuguesa, e teve sua regulamentação estabelecida pelo Tratado de Madri em 1750. A anexação de novas áreas por Portugal permitiu a consolidação da configuração territorial inicial de Goiás, transpondo o meridiano $49^{\circ}$ oeste de Greenwich (Meridiano de Tordesilhas), o qual praticamente dividia pela metade, o território que mais tarde viria a ser da capitania.

Deve-se ressaltar que várias incursões foram feitas, principalmente na Bacia do Prata e na Bacia Amazônica. As primeiras explorações na Capitania de Goiás ocorreram no século XVII e início do século XVIII pelos missionários e nortistas, através das vias fluviais Araguaia/Tocantins (ao norte) e pelos bandeirantes paulistas (ao sul), visando a preação de índios e a procura de recursos minerais.

Em 1725, a ocupação começou a se processar de forma sistemática e organizada, com a exploração do ouro iniciando o primeiro ciclo da mineração (1725 - 1751) (BARREIRA, 2002). Ocorre então a fundação de arraiais e a abertura de estradas devido ao aumento populacional provocado pela chegada dos garimpeiros, a instalação das fazendas de criação de gado e a incursão de mascates e comerciantes em geral na região.

A capitania de Goiás foi criada oficialmente em 1744, no auge do ciclo da extração de ouro de veio d'água e de jazidas a flor da terra. Esse tipo de mineração fez com que várias povoações surgissem ao longo dos rios Vermelho, Santa Cruz, Meia Ponte, Crixás, Guarinos e

\footnotetext{
${ }^{7}$ Foi a união das coroas portuguesa e espanhola entre os anos de 1580 e 1640, unificando os países ibéricos. Para Castro, "no período da União Ibérica os Portugueses puderam avançar de maneira pacífica pela Amazônia e ainda ocupar as nascentes do Prata, estabelecendo as capitanias de Santa Catarina e de Mato Grosso" (1986, p. 8).
} 
Maranhão. Apesar de ter sido criada em 1744, os limites da Capitania só foram estabelecidos alguns anos depois, feito realizado por Dom Marcos de Noronha, então Governador da Província de Goiás.

Após o período minerador, a econômica goiana entrou em uma fase de decadência, o que foi alterado apenas mais tarde, no final do século XIX. Neste período, o sul de Goiás e o Triângulo Mineiro (este separado da Capitania de Goiás em 1816) foram influenciados pela expansão cafeeira paulista, que propiciou a chegada da estrada de ferro e estimulou a urbanização e a agricultura comercial.

A Estrada de Ferro em Goiás provocou um novo período de dinamismo por causa da intensificação da ocupação do território, especialmente em função das demandas paulistas por alimentos. A presença das ferrovias em Goiás revigorou o processo de transmissão mercantil de propriedades na parte sul do estado, atraiu populações de Minas Gerais e São Paulo, “instigou o surgimento de pequenos centros urbanos ao derredor das estações ferroviárias e possibilitou o incremento da produção de alimentos, principalmente do arroz que tornou-se depois do gado - importante produto na pauta de exportação" (ESTEVÃO, 2004, p. 89).

Essa modernização econômica em Goiás provocou a criação de novas cidades e estimulou o aumento demográfico na região, especialmente com a criação de novas vias de acesso, para atender a expansão da produção. Dessa forma, o território goiano fornecia ainda, passagem para as estradas que levavam às minas de Cuiabá e as demais localidades situadas ao norte do Brasil. Essas estradas deram origem às importantes vias de ligação que integraram as áreas da antiga capitania de Goiás à nação. Portanto, o contexto econômico do Estado apresentava franco crescimento populacional e econômico.

Nesta ocasião, a dinamicidade vivida em Goiás não foi homogênea, pois se concentrou especialmente na região "cortada" pela estrada de ferro, e nela causou uma série de transformações espaciais vinculada aos transportes. Um exemplo de cidades desta região, foi Ipameri. Conforme Inocêncio (2000, p. 99), "a estrada de ferro provocou enorme desenvolvimento na cidade de Ipameri entre os anos de 1914 a 1919, a ponto de ser considerada a sala de visitas do Estado de Goiás, a princesinha do Sudeste Goiano". Isso se deveu principalmente ao fato desta cidade ter sido a ponta da ferrovia no referido período.

O fato de ser o ponto ferroviário mais avançado no interior de Goiás para o embarque e desembarque de diversos produtos e de passageiros que iam e viam do litoral resulta nesse volume de desenvolvimento. Outro fator para o desenvolvimento diferencial das cidades 
próximas aos trilhos, e principalmente Ipameri, se deu principalmente pela facilidade de transportar as mercadorias ali produzidas até os centros de consumo paulistas.

Dessa forma, a quantidade de produtos negociados, e, consequentemente o volume de capitais disponíveis no comércio de cidades servidas pelas ferrovias, como Ipameri, resultou no que Inocêncio intitula "enorme desenvolvimento". Essas melhorias aos poucos estendeu-se a renda da população, e por isso, levou à readequação da infraestrutura urbana e econômica de tais cidades, tanto no crescimento quanto na modernização.

Figura 21 - Locomotiva n 403, tipo "Mallet”, pertencente à Estrada de Ferro Goiás.

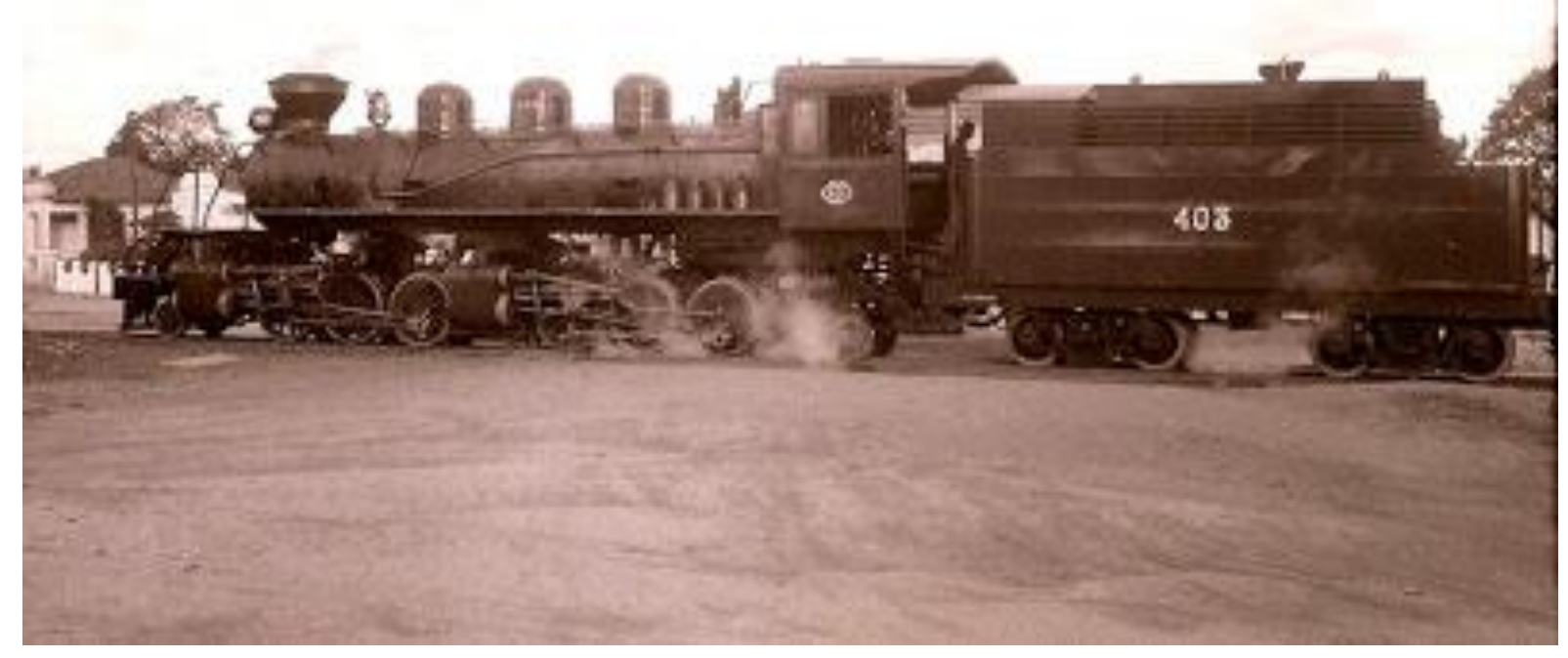

Fonte: AMANTES DAS FERROVIAS. Disponível em <http://www.amantesdaferrovia.com.br/profiles/ blogs/saudosas-locomotivas-da-estrada-de-ferro-goi-s>, acessado em 24 maio 2014.

Portanto, essas locomotivas foram responsáveis por dinamizar a economia de várias cidades goianas como Ipameri. A crescente influência de Ipameri, possibilitada pela presença da ferrovia culminou inclusive com a transferência do $6^{\circ}$ Batalhão de Caçadores em 1922, retirando-se da Cidade de Goiás, na época capital do Estado. Outros motivos também colaboraram, como a necessidade de melhorar a comunicação entre a tropa e o escalão superior.

Tais fatores possibilitaram às tropas federais a facilidade de circulação propiciada pela ferrovia. A transferência do $6^{\circ} \mathrm{BC}$ para Ipameri foi impulsionado também pelo crescimento 
populacional vivido por ela, somando-se as vantagens oferecidas pela diversidade do comércio local. A facilidade para a mobilização das tropas também deve ser considerada, pois doravante sempre poderia auxiliar nas ações de defesa nacional em várias partes do país, ou até mesmo fora dele, com maior rapidez.

Conforme pode ser observado anteriormente, a rede ferroviária no Brasil foi construída a partir do litoral e aos poucos adentrou no interior do território. No caso do Brasil Central, as ferrovias chegaram apenas no início do século XX, a partir de 1913, quando atravessou o rio Paranaíba e chegou ao Estado de Goiás. Já em 1914 a ferrovia atingiu a cidade de Roncador, antiga vila de operários da ferrovia que situava-se a poucos quilômetros ao norte do rio, e propiciou o início de uma nova fase econômica no Brasil Central. Sobre este assunto Estevão observa:

O prolongamento dos trilhos até Goiás revigorou o processo de transmissão mercantil de propriedades na área meridional, atraiu imigrantes de Minas Gerais e São Paulo, instigou o surgimento de pequenos centros urbanos ao derredor as estações ferroviárias e possibilitou o incremento da produção de alimentos, principalmente do arroz que se tornou - depois do gado - importante produto na pauta de exportação (2004: 89).

Desde então, percebeu-se que o Estado de Goiás viveu um novo momento de incremento econômico a partir do crescimento da agricultura, da pecuária e da chegada de migrantes. Consequentemente ocorre a introdução de novas técnicas e tecnologias na agricultura, na pecuária, nos transportes, nos comércios, especialmente com a disponibilidade de produtos e serviços que até então eram restritos apenas aos moradores do litoral brasileiro, ou em áreas de influência ferroviária.

O contato com pessoas de diferentes culturas, tanto das áreas mais dinâmicas do país, quanto de estrangeiros, contribuiu para a música, a moda, os costumes, as relações sociais. Para se ter uma ideia, a cidade de Ipameri, na região da estrada de ferro goiana, possui o maior número de pianos per capita do Estado. A estrada de ferro possibilitou ainda o surgimento de novas cidades, a modernização daquelas localizadas nas áreas de influência dos trilhos, o intercâmbio cultural e a paulatina atualização técnica e tecnológica de Goiás.

O estado de Goiás ganha com a chegada dos trilhos, uma vez que a retomada do crescimento econômico foi contagiante e aos poucos atingiu as áreas próximas à ferrovia, mesmo que em níveis e intensidades diferentes. Desta forma, a "região da estrada de ferro" foi a mais beneficiada de todo o Estado, pois a proximidade com o "trem" facilitava as trocas comerciais. A figura 22 mostra a área de abrangência da Estrada de Ferro Goiás em 1927. 


\section{ESTRADA DE FERRO GOIÁS EM 1927}

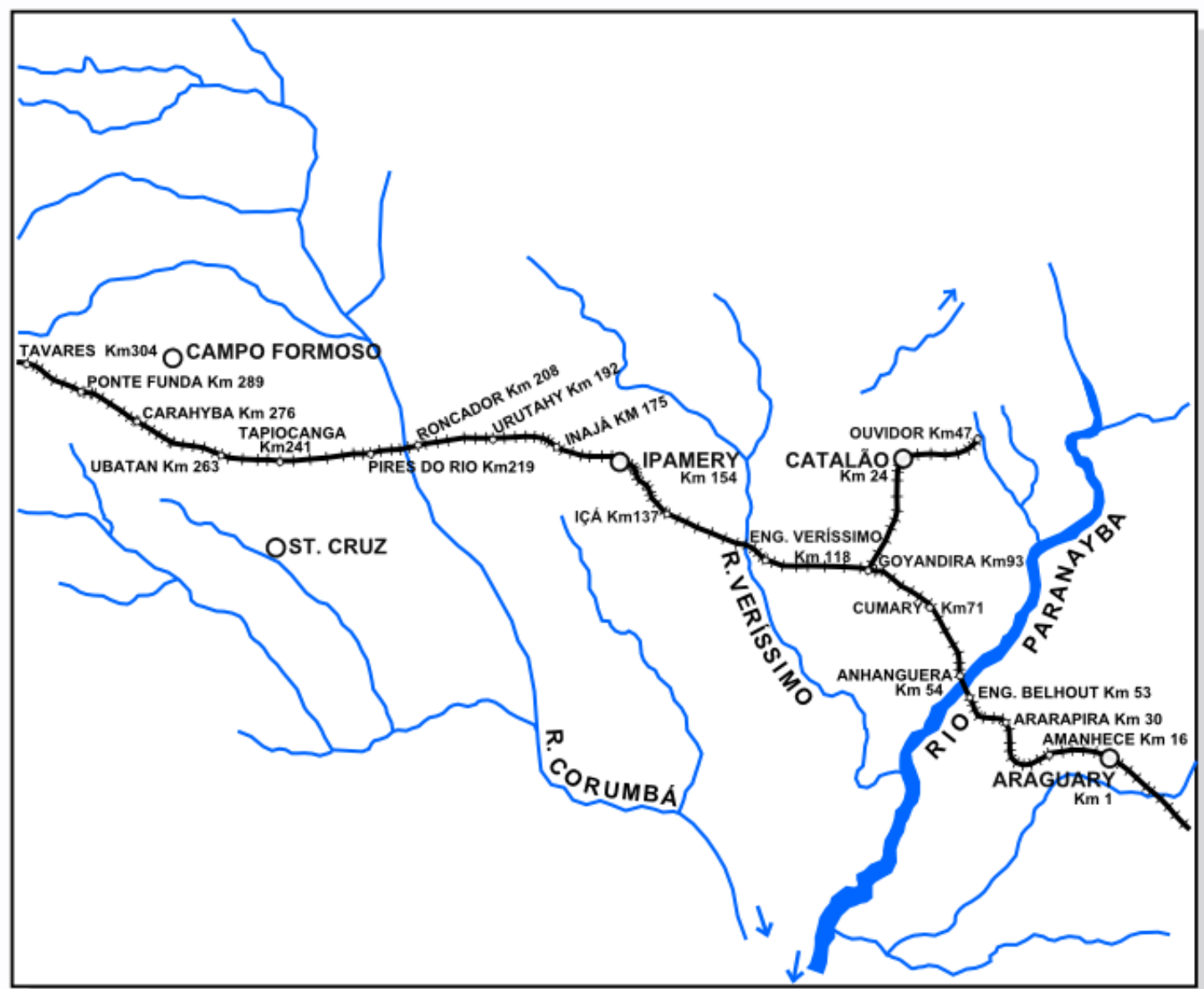

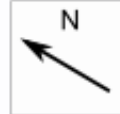

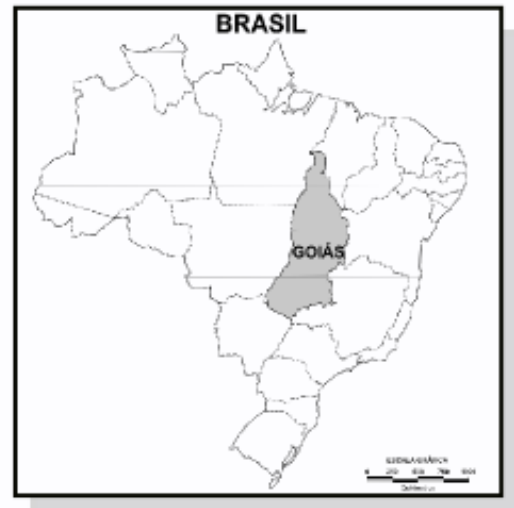

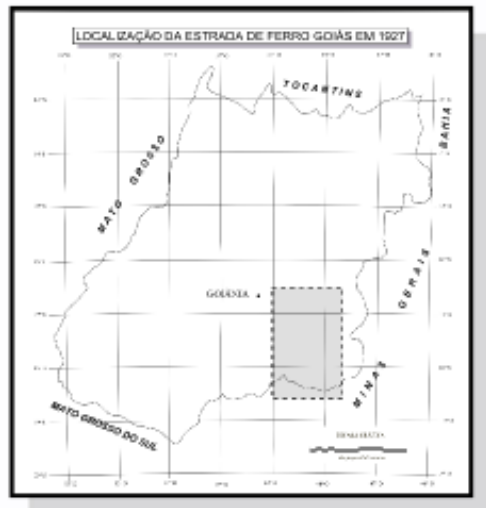

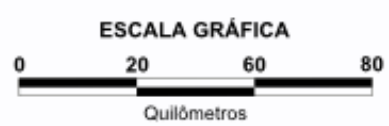

LEGENDA

ESTRADA DE FERRO GOIÁS

HIDROGRAFIA

PRINCIPAIS CIDADES

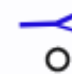

ESTAÇŌES DA E.F. GOIAS

Organização e Cartografia Digital:

Marajá Joăo Alves de Mendonça Filho

Fonte:

SIMIELLI, Maria Elena. Geoatlas, $31^{\mathrm{a}} \mathrm{ed}$

São Paulo: Ática, 2002.

VFCO. Centro Oeste. Disponivel em

<http://vfco.brazilia.jor.br/>, acessado em

06 mar 2014.

Figura: 22 
Especificamente na área de abrangência da estrada de ferro, as relações econômicosociais passam por mudanças. A agropecuária de subsistência é paulatinamente substituída pela produção de gêneros alimentícios destinados ao mercado paulista. Ocorre também, modificações no comércio com a abertura de estabelecimentos comerciais, muitos montados por migrantes o que ocasionou mudanças na estrutura social e econômica goiana. Inovações comerciais ocorreram tanto nos tipos de produtos, como também nas formas de atendimento. Além disso, a influência dos migrantes europeus também contribuiu para uma visão mais intelectualizada e moderna acerca dos assuntos da época.

A Estrada de Ferro Goiás iniciava a partir do final da Estrada de Ferro Mogiana, na cidade de Araguari - MG, sendo, portanto, seu “km 1", e seguia pelas cidades mineiras de Amanhece, Ararapira e Eng. Belhout, atravessando o Rio Paranaíba e chegando à cidade goiana de Anhanguera. Em Goiás, passa pelas cidades de Cumary, Goiandira, Eng. Veríssimo, Içá, Ipameri, Inajá, Urutaí, Roncador, Pires do Rio, Tapiocanga, Ubatã, Caraíba, Ponte Funda e Tavares, sendo esta cidade, seu "Km 304".

A implantação da ferrovia em Goiás ocorreu em etapas. Na primeira, que vai até 1914, os trilhos avançaram 233 quilômetros, trecho construído em um período relativamente curto, partindo de Araguari-MG até Roncador-GO. Os trilhos ficaram paralisados em Roncador até 1922, para a construção de uma ponte sobre o rio Corumbá, quando foi iniciada a segunda etapa, esta porém, mais demorada e irregular. Tal demora deveu se a interesses políticos das antigas oligarquias goianas, que temiam perder privilégios que possuíam, na medida que as inovações sociais e econômicas das ferrovias poderiam resultam em riscos.

Somente após romper com os interesses das forças políticas conservadoras é que as articulações políticas progressistas conseguiram "destravar" a paralisação das obras. Isso explica os motivos pelos quais "No seu prolongamento, a ferrovia atingiu Anápolis (1935) completando 387 quilômetros de extensão. Somente em 1950 inaugurou-se um ramal ligando Leopoldo de Bulhões a Goiânia" (ESTEVÃO, 2004: 82).

Percebe-se que a atual configuração da rede ferroviária goiana levou 37 anos para ficar pronta, de modo que proporcionou a paulatina integração econômica do Sudeste Goiano, do Mato Grosso Goiano, e mais tarde do Entorno de Brasília, com o polo econômico do país - o Sudeste, comandado por São Paulo. Sem dúvidas foi uma das construções ferroviárias mais demoradas do país, não pela falta de recursos, mas, devido aos boicotes políticos. Houve um grande jogo de interesses seja para avançar os trilhos, e também em impedi-los de serem construídos, dependendo da cidade e da articulação política e econômica. 
A ideia de ter o final da linha proporcionava para a localidades que estavam em tal condição uma grande vantagem em termos de negócios. Ou seja, via trilhos, tal cidade tornava-se o ponto de acesso mais próximo do centro econômico da nação, o Sudeste, e por isso, dinamizava o escoamento da produção e também a aquisição de mercadorias que não eram fabricadas em Goiás. De acordo com Teixeira (2013: 40) “a rede ferroviária foi, portanto, um dos elementos sócio espaciais que provocaram verdadeiras arenas políticas no período de sua instalação, porque onde chegava a ferrovia materializa-se a riqueza e o prestígio político de seus idealizadores".

No campo político, as disputas entre os ludovicos e os caiados foi intensa. Segundo Teixeira (IDEM: 41) “a Estrada de Ferro em Goiás, vinda do Triângulo Mineiro na década de 1930, mudou a configuração territorial goiana, porque alterou a direção desenvolvimentista do estado do Norte para o Sul, e ao mesmo tempo, acelerou o colapso de poder político dos caiado". Os caiados, oligarquia tradicional da Cidade de Goiás, não tinham interesse em fortalecer a economia em áreas distantes da sua zona de influência. Dessa forma, impedir a chegada dos trilhos significava manter seus negócios intocáveis e garantir a manutenção da sua condição econômica e política.

Todavia, a insatisfação dos outros políticos das regiões boicotadas pela ausência das ferrovias, como os vinculados aos produtores de café da região de Inhumas, gerou o rompimento de suas alianças com os caiados. Consequentemente, uniram-se aos ludovicos, sobretudo devido ao projeto de construção da nova capital de Goiás - Goiânia. Os trilhos que inicialmente estavam previstos para chegar a Cidade de Goiás, reduto caiadista, agora foram direcionados para Goiânia, a partir da estação de Leopoldo de Bulhões. Mesmo assim, os trilhos que alcançaram Anápolis em 1930, levaram mais vinte e dois anos para chegar em Goiânia, que passou a contar com a ferrovia apenas em 1952. Ou seja, levou-se tanto tempo para construir aproximadamente 90 quilômetros de trilhos.

Evidencia-se que a construção da rede férrea em Goiás representou mais que apenas uma empreitada no campo da economia via expansão das áreas produtivas. Significou também, a partir da construção de Goiânia na década de 1930, e mais tarde sua ligação ferroviária na década de 1950, a paulatina incorporação das regiões interiores do país via a política da Marcha para o Oeste. Após a ligação de Goiânia com a ferrovia, foi a vez de expandir os trilhos até a nova capital federal, Brasília, que foi construída a partir do governo de Juscelino Kubistchek em 1957 e inaugurada em 1960. A figura 23 mostra a articulação da E.F. Goiás no Brasil. 


\section{ESTRADA DE FERRO GOIÁS E SUAS PRINCIPAIS ARTICULAÇÕES EM 1970}

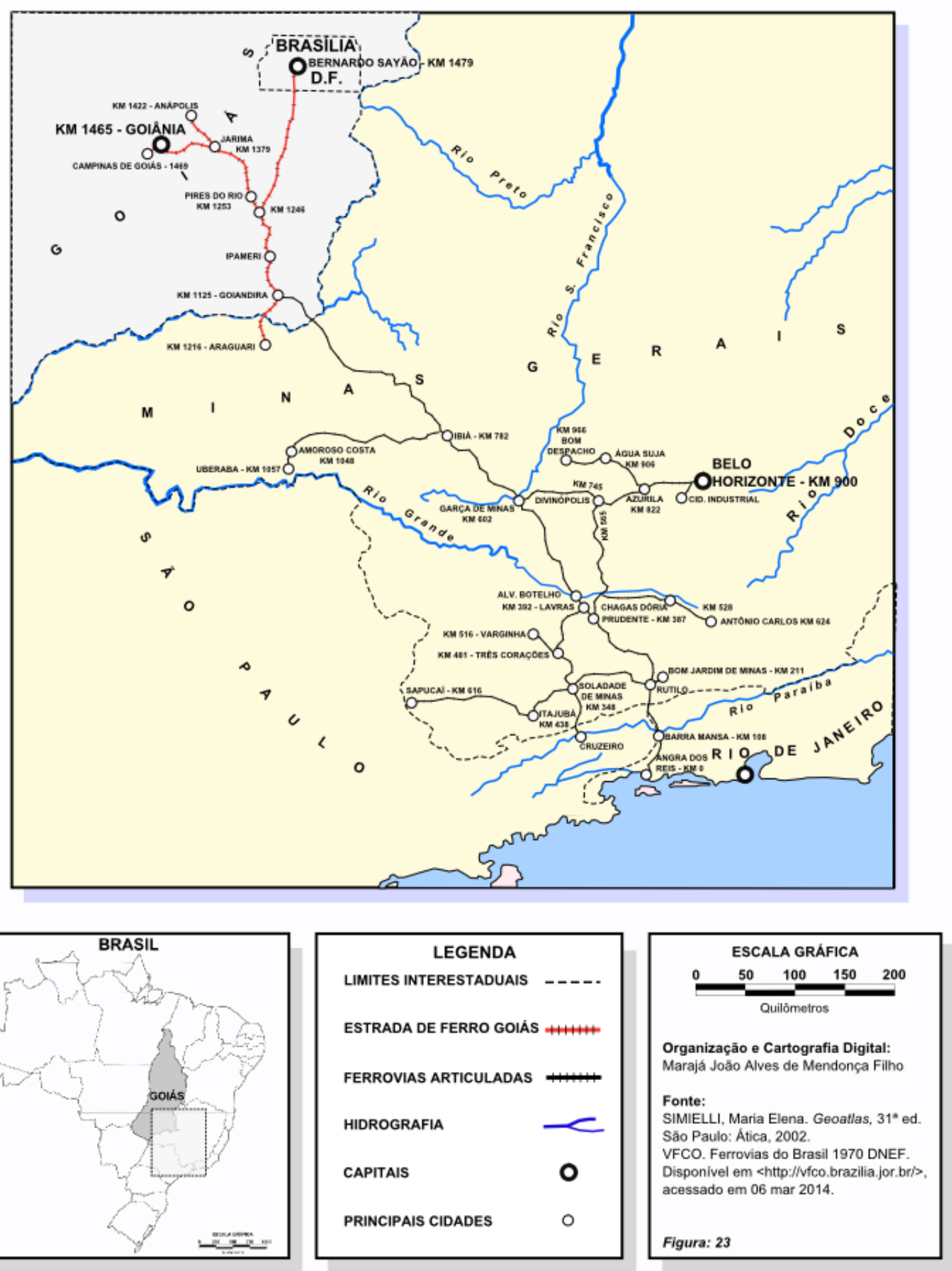


O trecho que ligou Brasília aos trilhos da Estrada de Ferro Goiás foi inaugurado em 1968, na estação Bernardo Sayão. Desta forma, a E. F. Goiás, dentro da rede ferroviária brasileira estabeleceu mais um importante "nó" aos já existentes no interior da nação. Passam a destacar no Centro Oeste, além de Brasília, os "nós” em Goiânia, Anápolis, Pires do Rio, Ipameri e Goiandira.

A partir de 1970, pelos trilhos da Estrada de Ferro Goiás atinge-se outros importantes pontos da rede, como a cidade mineira de Araguari, que foi sede do $2^{\circ}$ Batalhão Ferroviário do Exército, chamado de "Batalhão Mauá", nome dado em homenagem ao construtor da primeira ferrovia brasileira, o Barão de Mauá. Esta unidade militar foi responsável pela construção da maior parte dos trilhos do interior do país. Atualmente a cidade de Araguari é sede do $11^{\circ}$ Batalhão de Engenharia de Construção, unidade militar do Exército que ocupou as antigas instalações do Batalhão Ferroviário. Ressalta-se também que em Araguari a Estrada de Ferro Goiás é ligada a Estrada de Ferro Mogiana.

Pela cidade goiana de Goiandira, a Estrada de Ferro Goiás conectava-se com a rede ferroviária brasileira pertencente à $5^{\mathrm{a}}$ Divisão da Rede Ferroviária Federal, rumo às cidades mineiras de Ibiá e em seguida, Garça de Minas. Desta cidade podia seguir até Belo Horizonte via Divinópolis, ou ir para o Rio de Janeiro via cidades mineiras de Álvaro Botelho, Lavras, Prudente e Rutilo. Por essa rota, adentra-se ao território carioca, atingindo a cidade de Barra Mansa e por ela o litoral na altura de Angra dos Reis.

$\mathrm{Na}$ cidade mineira de Lavras era possível seguir também pela ferrovia que vai a Três Corações e Soledade de Minas. A partir desta cidade é possível chegar ao território paulista pelo sentido sul, até a cidade de Cruzeiro, e pelo sentido oeste, através das cidades mineiras de Itajubá e Sapucaí, chegar também ao Estado de São Paulo via FEPASA, na cidade de Mogi Mirim.

A rede ferroviária em Goiás foi consolidada em 1952, com a inauguração do trecho até Goiânia, somando 480 quilômetros. Aproximadamente 30 estações serviam a rede férrea em Goiás. Entretanto, a partir da construção de Brasília, e com ela a mudança na matriz de transportes para o modal rodoviário, houve uma paulatina diminuição da importância das ferrovias. Teixeira observa que "o sonho de encurtamento das distâncias entre os estados brasileiros via Estrada de Ferro de Goiás foi paulatinamente perdendo força com a inserção da malha rodoviária na década de 1970" (2013: 44). Mais tarde, a partir da privatização ocorrida na década de 1990, tais ferrovias passaram a fazer parte da Ferrovia Centro-Atlântica - FCA. Segundo o Ministério dos Transportes (2014), 
A Ferrovia Centro-Atlântica (FCA) tornou-se uma concessionária do transporte ferroviário de cargas em setembro de 1996, a partir do processo de desestatização da Rede Ferroviária Federal. Responsável pela operação de uma malha de $7.840 \mathrm{~km}$ de linhas, a FCA hoje abrange sete estados - Minas Gerais, Espírito Santo, Rio de Janeiro, Sergipe, Goiás, Bahia, São Paulo - além do Distrito Federal. A FCA é também o principal eixo de conexão entre as regiões Nordeste, Sudeste e CentroOeste. Sua frota atual é composta de cerca de 12.000 vagões e 500 locomotivas, todas monitoradas via satélite (GPS).

Os principais produtos transportados pela FCA são: álcool e derivados de petróleo, calcário, produtos siderúrgicos, soja, farelo de soja, cimento, bauxita, ferro gusa, clínquer, fosfato, cal e produtos petroquímicos. Ressalta-se ainda que

A FCA é um complexo sistema logístico de transporte. Está interligada com as
principais ferrovias brasileiras e possui parcerias com outros modais, o que
possibilita a conexão com os maiores centros consumidores do Brasil e do
MERCOSUL. Em setembro de 2003, autorizada pela Agência Nacional de
Transportes Terrestres (ANTT), a Companhia Vale do Rio Doce assumiu o controle
acionário da Ferrovia Centro-Atlântica, fortalecendo o processo de gestão e
recuperação da empresa. Assim, os clientes da Logística Vale beneficiam-se da
integração da malha FCA com a estrutura da logística CVRD, que conta com mais
duas ferrovias - a Estrada de Ferro Vitória a Minas (EFVM) e Estrada de Ferro
Carajás (EFC) - portos, serviços de navegação costeira e armazéns, o que possibilita
a composição de inúmeras soluções intermodais para os clientes (Ministério dos
Transportes, 2014).

A ferrovia Centro - Atlântica é, portanto, composta por uma malha férrea que conecta os portos do Sudeste brasileiro ao interior dos estados da própria região, e também de estados das regiões Nordeste e Centro - Oeste do país. São mais de oito mil quilômetros de ferrovias das quais pouco mais de seiscentos situam-se no estado de Goiás.

As cidades de Goiânia, Anápolis e Brasília, constituem os destinos mais avançados da ferrovia Centro - Atlântica, dentro da região Centro Oeste. Os trechos ferroviários que ligam tais cidade se juntam em Roncador Novo - GO, e segue por Goiandira, Araguari, Patrocínio, e Ibiá. Desta cidade pode-se seguir dois caminhos: um que segue para Araxá e Uberaba, e outro que segue para Garças de Minas. De lá, pode se acessar as cidades mineiras de Arcos ou Divinópolis. No sentido de Arcos, a ferrovia passa por Formiga, Lavras, Eng. Bhering. Desta cidade pode se acessar o interior de Minas via cidades de Três Corações e Varginha, ou seguir por Barra Mansa, Lídice até chegar ao porto de Angra dos Reis.

No sentido de Divinópolis, a rede férrea passa por Embiruçu, Eldorado, Calafate, Belo Horizonte e General Carneiro. De lá pode-se seguir para o litoral carioca, via Itabirito, Miguel Burnier, Lafaiete Bandeira, Ponte Nova, Barão de Camargos, Recreito e Três Rios. Em Recreio ainda há como seguir para Campos, e de lá chegar a Vitória, no Espírito Santo, ou a 
Praia Formosa. Por outro lado, se o objetivo for o Nordeste, basta em General Carneiro seguir para o norte, rumo a Pedreira, Capitão Eduardo, Prudente de Morais, Curveio, Corinto, Montes Claros, Brumado, Mapele, São Francisco, Aracaju e Propriá. Em São Francisco também é possível chegar a Juazeiro - BA, divisão com Petrolina - PE. Em Mapele pode se acessar a capital da Bahia - Salvador, e em Corinto, pode se acessar a cidade de Pirapora MG. A figura 24 mostra os principais pontos e as respectivas distâncias em quilômetros da atual rede da FCA.

Figura 24 - Diagrama Unifilar da Ferrovia Centro Atlântica - FCA.

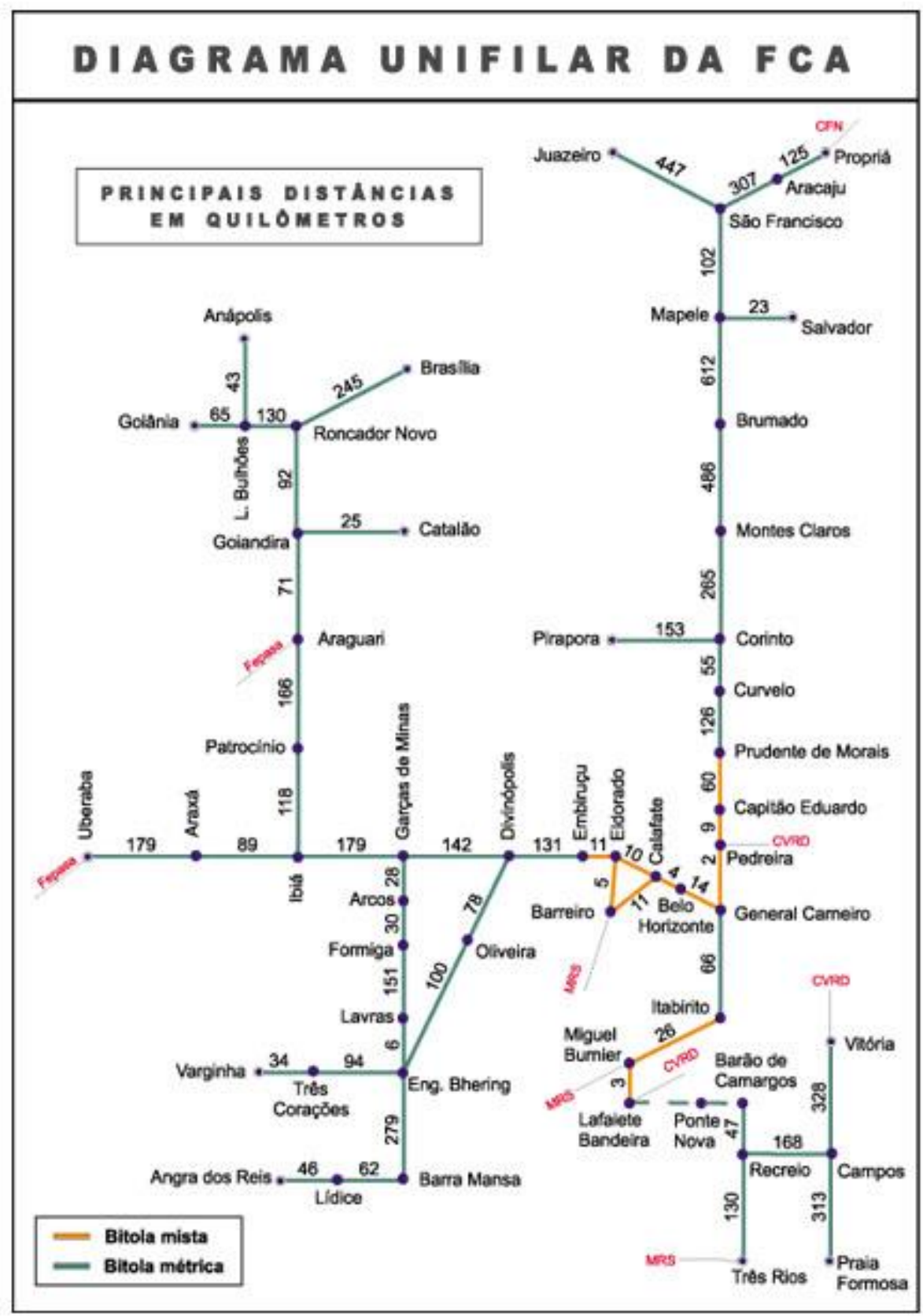

Fonte: FCA, 2011. 
As influências das ferrovias e posteriormente das rodovias são tão marcantes que as áreas mais distantes do litoral são beneficiadas primeiro. É o caso das regiões da Estrada de Ferro, do Sul Goiano e Mato Grosso Goiano, que são dinamizadas antes das regiões do Entorno de Brasília e Nordeste Goiano. Isso mostra a força das redes logísticas no ordenamento territorial brasileiro, neste caso, sobretudo as ferrovias.

Por isso, a região sudeste de Goiás, também conhecida como região da Estrada de Ferro, foi a primeira a vivenciar a chegada das frentes pioneiras em Goiás, seguida posteriormente pelas regiões Sudoeste, Sul e Mato Grosso Goiano. Posteriormente, com a construção da Belém - Brasília, a região do seu eixo, ao norte do Mato Grosso Goiano, também é contemplada. Percebe-se que foi pelas ferrovias que as mudanças se intensificam, os migrantes chegam e a economia se dinamiza. Por elas, a transformação das frentes de expansão em frentes pioneiras se manifesta, mediante a intensificação da apropriação capitalista do território e a conversão dos seus recursos e potencialidades naturais em mercadorias.

A dinamização econômica a partir das frentes pioneiras em Goiás que predominou inicialmente nas regiões próximas das ferrovias, antes da construção de Brasília, após a sua inauguração no início da década de 1960, passa paulatinamente a ocorrer via rodovias. Isso se deve a presença das diversas rodovias federais que passaram a ligar a nova capital com todas as regiões do Brasil, como a BR - 153, que conecta Brasília a Belém. Assim, percebe-se que o as regiões goianas mais distantes da ferrovia passaram a também ser dinamizadas.

Isso explica os motivos que levaram, a estrada de ferro em Goiás vivenciar o início de um período de estagnação a partir da década de 1950. Além da construção de diversas rodovias, houve também o aumento do número de estradas vicinais, as quais passaram a receber o transporte de cargas e passageiros que anteriormente eram feitos pela ferrovia. A flexibilidade dos automóveis provocou a paulatina mudança do modelo de transporte, uma vez que proporcionava maior liberdade de ação, alcançando as áreas distantes dos trilhos. Tal fato fez com que o transporte ferroviário, principalmente de passageiros diminuísse constantemente, passando a ser feito pelos caminhões e pelos ônibus das viações que se instalam no estado.

Por isso as regiões goianas conhecidas como Entorno de Brasília, Eixo da GO - 060, Estrada do Boi e Nordeste Goiano foram dinamizadas a partir da década de 1960. Embora a ferrovia tenha estancado o seu crescimento, a dinamização da economia goiana seguiu seu caminho, doravante feito por rodovias. A figura 25 detalha a ocupação. 


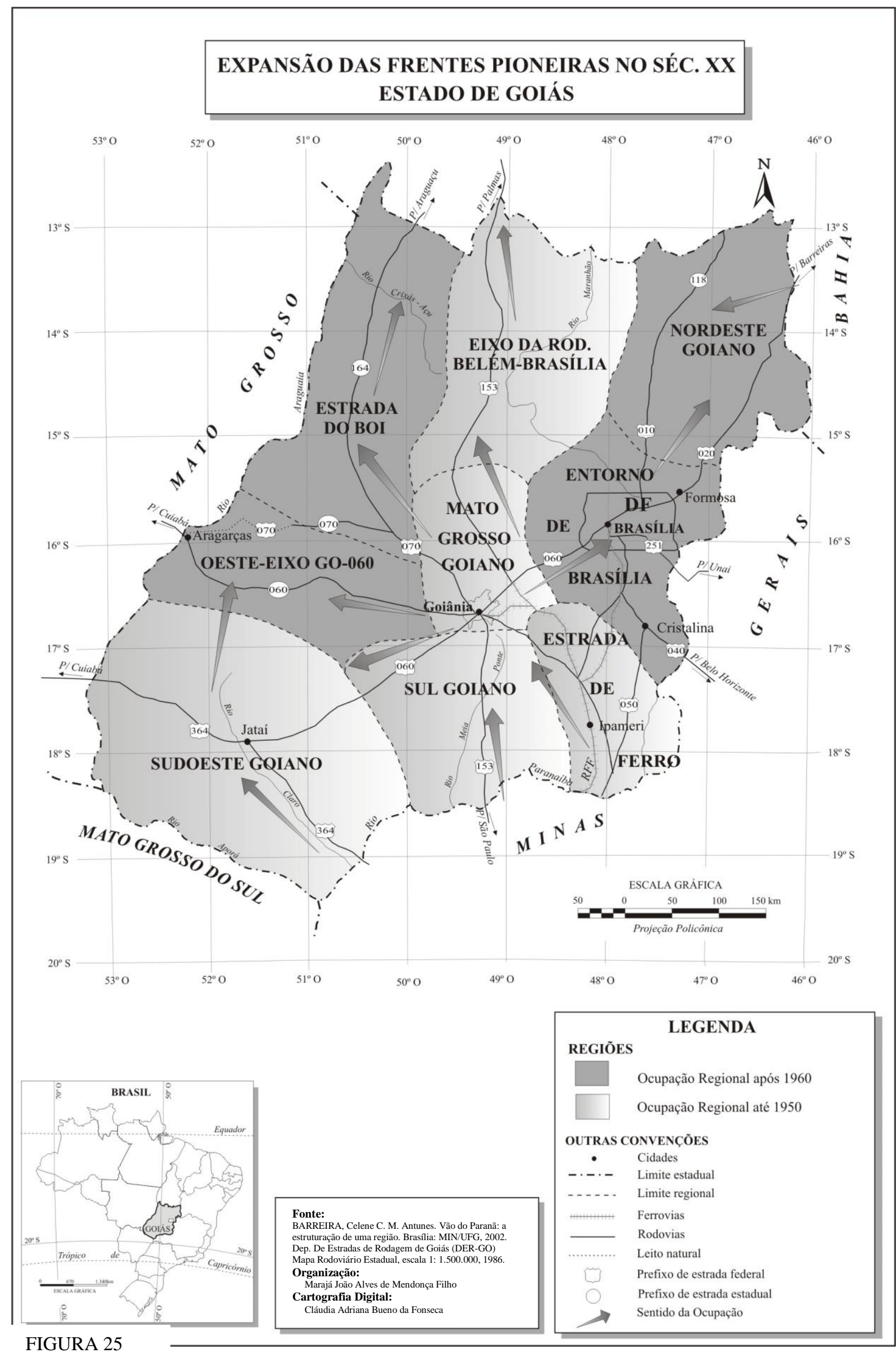

FIGURA 25 
Outro aspecto que chama a atenção, já a partir da década de 1980, foi o fato do transporte de passageiros deixar de ser realizado nas linhas férreas goianas, as quais passam a dedicar-se exclusivamente ao transporte de cargas. Na década de 1990 houve a privatização do sistema ferroviário nacional, o que permitiu a retomada dos investimentos no setor e o fortalecimento do transporte de cargas, principalmente na ferrovia goiana. Porém, não houve investimento no transporte de passageiros. Por isso, dos anos 1980 em diante, várias estações ferroviárias em Goiás foram paulatinamente fechadas e muitas delas acabaram totalmente abandonadas.

\subsection{INTEGRAÇÃO FERROVIÁRIA NO CENTRO OESTE}

Além das ferrovias goianas, foi também construída no Centro Oeste a Estrada de Ferro Noroeste a partir de 1940, ligando as malhas paulistas às áreas do que seria o Estado de Mato Grosso do Sul, que a época ainda era parte do Estado de Mato Grosso, até a fronteira com o Paraguai. Com já observado anteriormente, o Estado do Mato Grosso do Sul foi criado apenas em 1977. As ferrovias do Mato Grosso representaram mais que o dobro da rede férrea goiana, totalizavam $1.170 \mathrm{~km}$, enquanto que as goianas somavam em 1940, $385 \mathrm{~km}$. Ambas ferrovias são conectadas com o Estado de São Paulo, e por ele, ao Oceano Atlântico.

Ressalta-se ainda que a ferrovia Madeira Mamoré, também fazia parte da rede matogrossense de ferrovia, estando na época na região Centro Oeste. Atualmente, a região da extinta Madeira Mamoré pertence ao Estado de Rondônia, criado em 1981 pelo presidente João Figueiredo, a partir do antigo território federal do Guaporé, este fundado em 1943 por Getúlio Vargas. Hoje faz parte da região Norte do Brasil.

Já a Estrada de Ferro Noroeste iniciava na cidade de Três Lagoas, em Mato Grosso e seguia rumo de Campo Grande, Aquidauana, Miranda, Porto Esperança e Corumbá, na divisa com o Paraguai. Ressalta-se que com a conclusão desta ferrovia, o Brasil passou a contar com um grande corredor de exportação leste oeste, responsável pelo transporte sobretudo de produtos do agronegócio, como a soja. Além disso, a importância geopolítica dessa ferrovia na rede logística nacional foi o de aumentar a importância do Brasil na América do Sul, com uma maior polarização sobre países como o Paraguai que passou a contar com o apoio logístico do Brasil para exportar suas mercadorias via ferrovias e portos brasileiros, com destinos acessados pelo Oceano Atlântico. Todavia não saiu do papel. A figura 26 detalha os traçados destas vias. 


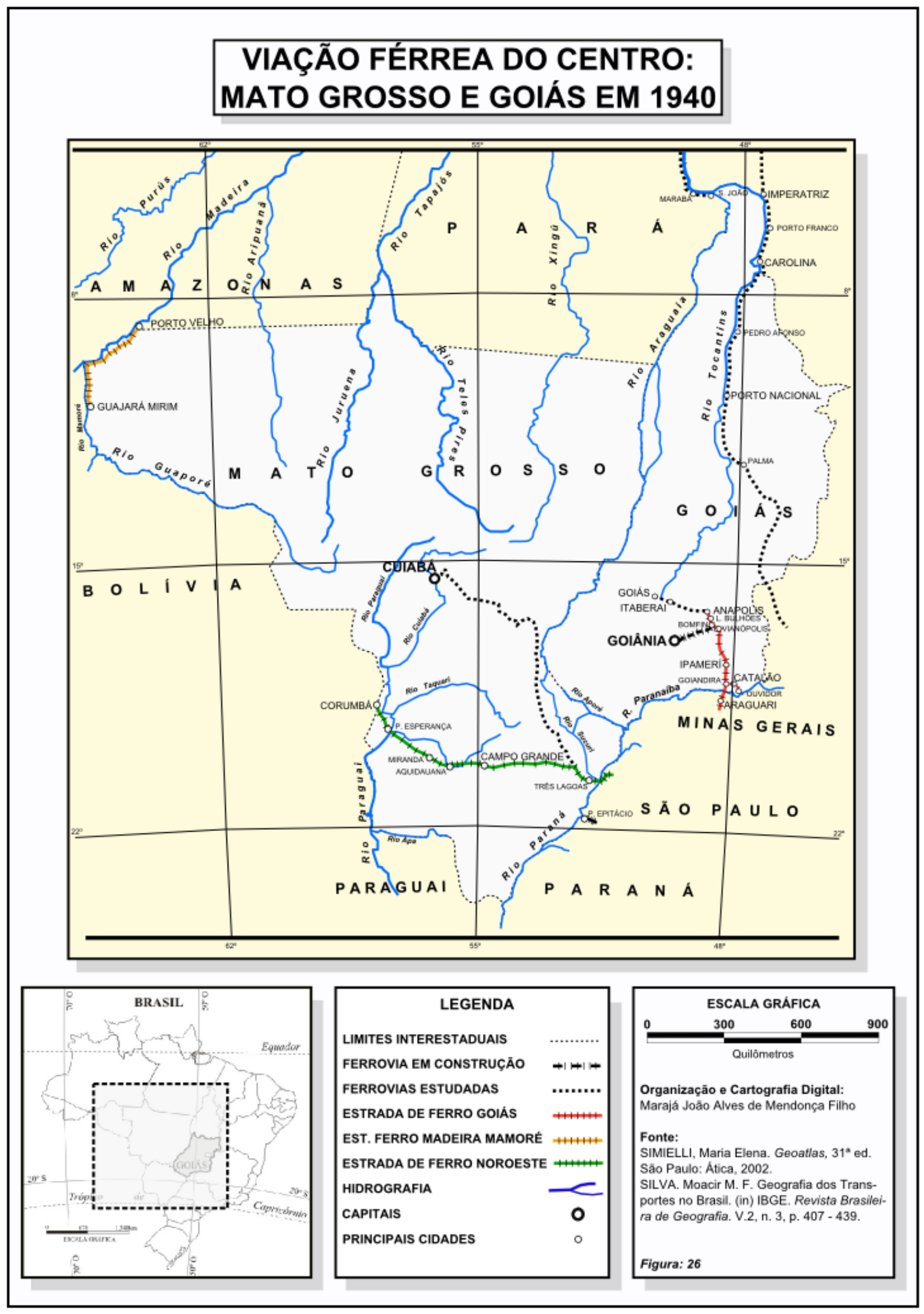


Por outro lado, a rede ferroviária de Mato Grosso também foi importante para que os produtos brasileiros fossem vendidos ao Paraguai, uma vez que a boa logística estabeleceu preços bem competitivos. Houve projetos para a extensão das redes férreas de Mato Grosso até a capital Cuiabá. A figura 26 mostra também, que na década de 1940 existia o projeto da construção da ferrovia Norte Sul, que atravessaria o Estado de Goiás. Esse primeiro projeto para a construção da ferrovia Norte Sul estabelecia a ligação das redes férreas mineiras com o Estado de Goiás, passando pelas cidades de Palma, Porto Nacional e Pedro Afonso, hoje cidades tocantinenses, até chegar no Maranhão, via cidade de Carolina. De lá seguiria sentido norte em direção às cidades maranhenses de Porto Franco e Imperatriz, para continuar até acessar, via rede ferroviária nordestina, o Atlântico.

Observa-se que em 1940 as ferrovias que adentravam o Centro-Oeste, vindas do sudeste brasileiro, contemplavam os estados de Goiás e Mato Grosso, pois como já observado, o Estado de Mato Grosso do Sul ainda não existia, muito menos o Distrito Federal. O Estado de Goiás ainda agregava a área do atual Estado do Tocantins, este criado apenas em 1988. Na década de 1940, o ramal que ligaria Goiânia à rede férrea goiana ainda estava em construção, e o projeto que ligaria a ferrovia até Cidade de Goiás, foi abandonado. O projeto da ferrovia norte sul, desta época também não saiu do papel.

Até hoje as ferrovias não alcançaram a cidade mato-grossense de Cuiabá. Após a divisão do Estado do Mato Grosso e Mato Grosso do Sul, a ferrovia noroeste ficou em solo sul-mato-grossense. Mais tarde, um ramal da extinta FEPASA, atual FERROBAN, foi estendido a partir da cidade paulista de Rubinéia e seguiu pelo norte do Estado de Mato Grosso do Sul, quase na divisa com Goiás, passando pelas cidades de Aparecida do Taboado, Inocência, Morangos, Chapadão do Sul, e atinge o Estado de Mato Grosso, ao Sul, na altura das cidades de Alto Taquari e Alto Araguaia. Esta ferrovia é chamada de FERRONORTE.

Doravante, as malhas ferroviárias do Centro-Oeste em funcionamento não tiveram grandes modificações, exceção feita pela atual ferrovia Norte - Sul, que teve boa parte concluída em 2014, ligando as malhas dos estados do Pará, Maranhão e Tocantins, até a cidade goiana de Anápolis. Na citada cidade, a ferrovia Norte Sul foi conectada a Ferrovia Centro Atlântica, que faz parte da rede férrea da região Sudeste e aos seus portos. A Ferrovia Centro Atlântica está conectada também às malhas ferroviárias das regiões Sul e Nordeste.

Várias outras ferrovias foram planejadas e algumas se encontram em fase de construção. Destacam-se a FICO - Ferrovia de Integração do Centro-Oeste, a expansão da FERRONORTE rumo à Rondônia e o Acre, e a conclusão em 2014 da Ferrovia Norte Sul. 


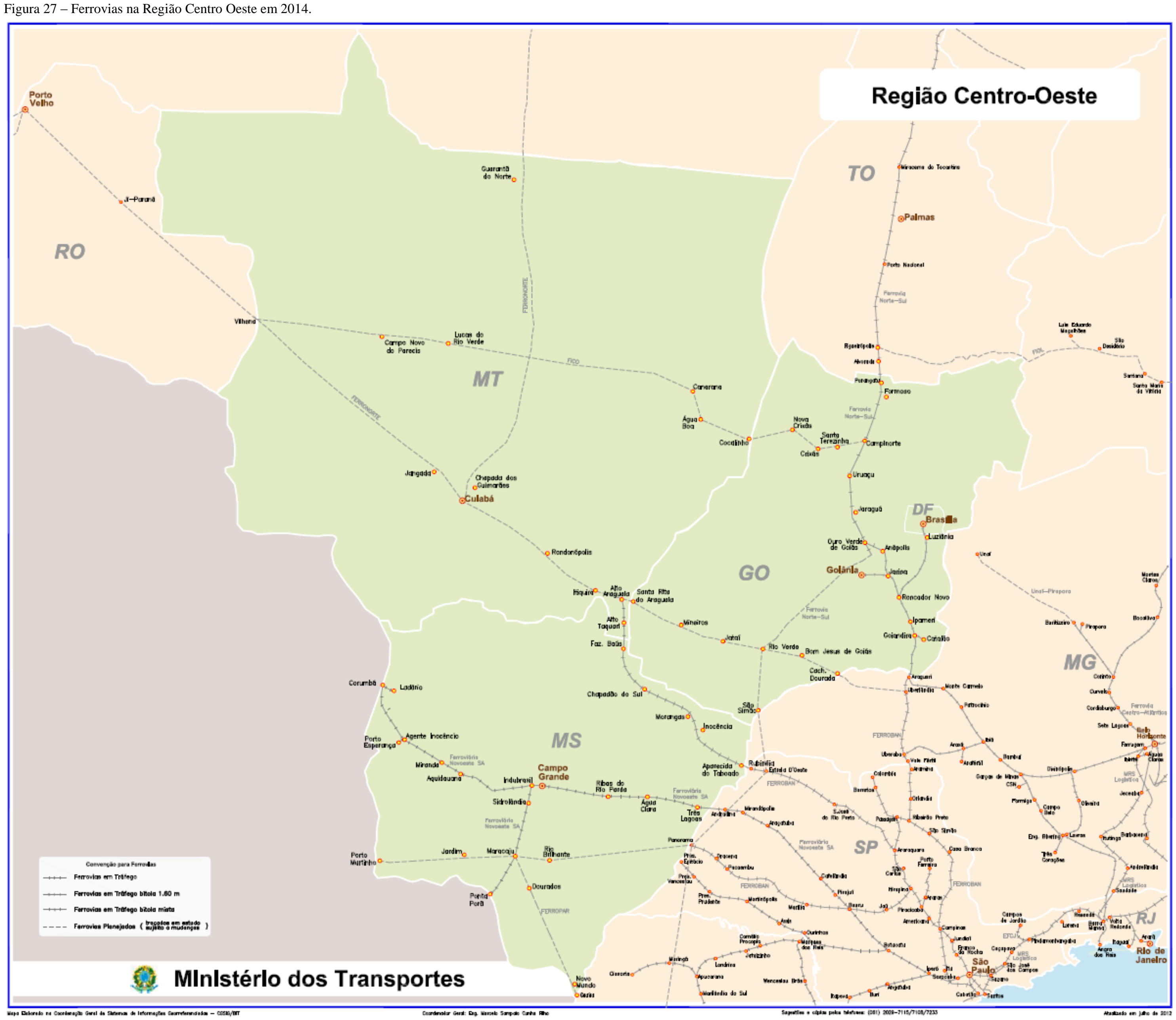


Com relação a esta ferrovia, está em construção o trecho chamado de "Tramo Sul" que pretende ligar a cidade goiana de Anápolis, passando por Rio Verde e São Simão até a cidade paulista de Rubinéia. De lá, os trilhos da Norte Sul atravessarão as áreas produtivas no interior dos estados de São Paulo, Paraná, Santa Catarina, e chegarão ao Rio Grande do Sul. As novas ferrovias foram destinadas ao aumento da integração ferroviária dos estados de Mato Grosso, Mato Grosso do Sul, Goiás, Tocantins e Pará, e da incorporação do Amazonas e do Acre, às demais redes férreas do país. Com isso, paulatinamente valoriza-se os estados das regiões Norte e Centro Oeste na rede logística do Brasil.

Mais especificamente, os transportes ferroviários no Centro-Oeste são consequência da sua evolução histórica, e recentemente, da reprivatização ocorrida no final do século passado em todo o país. Conforme discutido no capítulo 1, a reprivatização ocorreu após um período de encampação estatal (1935-1971), lembrando que antes deste período as ferrovias eram privadas. No plano federal, foi criada a RFFSA e, em âmbito estadual (São Paulo), a FEPASA. A gerência estatal atendeu à expectativa de expansão de cargas no Brasil entre 1970 e 1990, comprovada pelos altos índices de produtividade alcançados, mas que mesmo assim apresentou problemas financeiros.

Proporcionalmente, apesar da redução no seu tamanho, a rede ferroviária chegou a transportar mais carga que a rodovia, não apenas em Goiás, mas, em todo o país. A redução de ramais considerados antieconômicos e a redução na pauta de produtos transportados geraram especialização e segmentação do mercado que contribuíram para o aumento dos índices de unidades de toneladas úteis (TU) e toneladas - quilômetros úteis (TKU) das ferrovias brasileiras sob controle estatal.

É preciso ressaltar que o Centro-Oeste como um todo foi alvo de consideráveis políticas públicas, destinadas principalmente ao incremento do agronegócio a partir dos anos 1970, em função da chamada "revolução verde". O resultado foi a grande produtividade agropecuária que passou a demandar grande quantidade de transporte para escoá-las até os mercados consumidores brasileiros e estrangeiros, o que foi feito à época, sobretudo pelas ferrovias que eram controladas pela RFFSA.

Mesmo com a melhoria de gestão da RFFSA, os leilões de privatizações ocorreram e o controle estatal das ferrovias foi passado para a iniciativa privada. Observa-se que a relação dos novos acionistas, vencedores dos leilões, em sua maioria, é formada por grupos brasileiros, pois conhecem bem a rede férrea nacional. Após a privatização, percebe-se que os índices de desempenho melhoraram consideravelmente, apesar da tendência de queda no nível 
de emprego no setor. Por outro lado, nas ferrovias brasileiras, a redução de postos de trabalhos chegou, em média, a 50\% quando se compara 1996 a 2001 (NUNES, 2012). Isso deveu-se sobretudo ao aumento da tecnologia empregada e de uma gestão mais eficiente.

Em Goiás houve o fechamento das estações ferroviárias e a diminuição do transporte de cargas de menor volume agregado, as quais passaram a ser transportadas pelos caminhões. As malhas da antiga Estrada de Ferro Goiás e da Mogiana, que estavam sob controle da RFFSA, após a reprivatização passaram a fazer parte da Ferrovia Centro Atlântica, a qual opera com foco em transporte de cargas com alto volume agregado, como grãos e minérios.

A comparação entre o processo de criação da Rede Ferroviária Federal, em 1957, unificando dezoito empresas, e o "novo" Estado pós-1990 que respondeu com a privatização da malha, reformulando também as agências de controle e execução da política, mostrou grande diferença. Destacam-se os atuais investimentos estatais na construção de novas ferrovias, sobretudo àquelas à cargo da VALEC, como é o caso da ferrovia Norte-Sul, que possui um considerável trecho em território goiano, e ainda, o projeto de privatização futura destas novas ferrovias.

Mesmo assim, é necessário investir ainda mais em ferrovias, não apenas em Goiás, mas em todo o Centro-Oeste, de modo a assegurar uma adequada infraestrutura de transportes mais baratos para atender as demandas advindas do crescimento econômico da região. Tal fato expressa a crescente necessidade de investimentos em transportes ferroviários por parte do Estado, pois atualmente não há interesse privado em investir na ampliação das ferrovias. Ou seja, o setor privado que ao longo da história foi responsável pela construção da maioria das ferrovias brasileiras, hoje busca apenas explorar e manter às já existentes.

Isso se deve aos altos custos envolvidos na construção das vias, principalmente com a indenização das áreas as serem desapropriadas. O resultado é que o estado brasileiro está usando recursos públicos para construir novas ferrovias para posteriormente entregá-las ao setor privado mediante financiamentos públicos. Como são investimentos de alto valor e que demoram anos para se ter retorno, aliado ao fato do setor privado querer investir apenas em áreas de rápido retorno financeiro, o estado passa a cumprir tal papel.

Essa situação expressa as contradições vividas não apenas por Goiás, que é um Estado localizado no interior do país, e portanto, precisa dispor de ferrovias adequadas para conectarse aos principais portos brasileiros, mas também, pelos demais Estados do Centro-Oeste. Adequar cada vez mais a rede férrea do Centro-Oeste ao contexto mundial de transportes, 
onde as nações mais desenvolvidas investem maciçamente em transportes sobre trilhos, é um desafio que precisará ser vencido para que o Brasil continue competitivo em nível mundial.

\subsection{A MARCHA PARA O OESTE E A CRIAÇÃO DE GOIÂNIA: BREVES CONSIDERAÇÕES}

Os fatos ocorridos durante a Primeira e a Segunda Guerras Mundiais provocaram incertezas no contexto geopolítico mundial, principalmente quanto à possibilidade da invasão estrangeira em áreas pouco povoadas do Brasil. Para evitar uma possível perda de território o governo federal criou políticas públicas para integrar e redistribuir parte do efetivo populacional no interior do país. Tais políticas foram parte da "Marcha para o Oeste" e foram desencadeadas a partir do Governo do Presidente Getúlio Vargas. Após a integração ferroviária e rodoviária entre as Regiões Nordeste, Sudeste e Sul do Brasil, foi a vez de integrar através de vias terrestres mais modernas, o Centro Oeste e com isso, criar as condições para posteriormente fazer o mesmo com a Região Norte.

Como parte da integração nacional, foi estabelecida, dentro outras estratégias, a mudança da capital goiana da Cidade de Goiás para Goiânia, a partir da sua construção na década de 1930. E para que isso fosse possível a Estrada de Ferro Goiás se destacou como principal via de acesso do Estado, e transportou boa parte dos materiais e matérias primas empregados na construção das infraestruturas, além dos trabalhadores envolvidos na empreitada.

Mais tarde, como sequência da "Marcha para o Oeste", a edificação de Brasília em pleno Planalto Central brasileiro foi outro grande marco na integração territorial, política, logística e social da nação. A necessidade de unir o "sertão" ao litoral, com a finalidade de ocupação das fronteiras a partir da incorporação dos cerrados e da Amazônia ao processo produtivo nacional, provocou a instalação e a modernização das vias de transporte. Com a nova capital federal e as grandes rodovias construídas para sua integração, como a BelémBrasília, a partir da década de 1960, ocorreu o deslocamento de grande quantidade de pessoas para as áreas de fronteira. Várias cidades foram criadas e houve a valorização nas terras incorporadas.

A região Centro-Oeste do Estado de Goiás houve a dinamização da ocupação com a criação da Colônia Agrícola Nacional de Goiás - CANG, depois da abertura da rodovia Belém-Brasília. A região Nordeste Goiano também recebe influência com a construção de 
Brasília devido à sua proximidade. Com a chegada dos trilhos, a agricultura foi fortemente estimulada se tornando a primeira região de Goiás atingida pela modernização e pela urbanização, sendo submetida a novos e dinâmicos fluxos migratórios.

Desde então a região Sudoeste Goiano começou a ser ocupada como uma extensão da frente pioneira que se espalha por todo o Sudeste na segunda metade do século XIX. No Sudeste Goiano, a base econômica inicial foi a pecuária, e se tornará agrícola a partir dos anos 1950 com a cultura do arroz e do algodão e posteriormente da soja. Os ricos solos, localizados em boa parte na bacia sedimentar do Paraná, originados da decomposição do basalto e do diabásico ("terra roxa") favoreceram a agricultura.

A incorporação dos cerrados pela "revolução verde", em especial após o fechamento da fronteira econômica e o avanço da fronteira agrícola, resultou em um novo contexto geopolítico nacional. A fronteira econômica diz respeito a incorporação de novas áreas ao sistema produtivo capitalista, havendo a conversão da própria terra em mercadoria. Já a fronteira agrícola faz alusão a apropriação territorial caracterizada pela conversão das matas em áreas produtivas mediante o emprego do trabalho, sendo este o responsável por caracterizar sua função social.

Neste período, o cerrado tornou-se uma grande área de produção nacional de grãos, especialmente com a chegada da soja, do milho, do sorgo e de outros produtos agrícolas. As práticas agrícolas intensivas foram incorporadas através do emprego de máquinas modernas, o uso de corretivos e fertilizantes químicos, e ainda, o uso de inseticidas. O Estado de Goiás ao localizar-se no centro geográfico do país, faz a ligação das regiões Sudeste e Sul do país com as regiões Norte e Nordeste, através das importantes ferrovias e rodovias construídas.

O Brasil Central é rico em terras pouco onduladas e férteis, originadas principalmente da decomposição do basalto e do diabásico (Sudoeste Goiano) e de gnaisses (Centro-Oeste e Sudeste), e terras menos férteis ao Norte, que com o emprego de corretivos e insumos, permitem a prática da agricultura intensiva, com alta produtividade. A região é ainda banhada por vários cursos d'água, os quais fazem parte de importantes bacias hidrográficas, com a do Araguaia - Tocantins e a do Paraná. Nessa lógica, o Estado de Goiás é privilegiado, também por possuir, no Espigão Mestre do Brasil, fronteira geográfica com a Bahia, um importante divisor de Bacias Hidrográficas, com terras férteis aproveitáveis pela agricultura. 
Pode-se afirmar que não foi por acaso que o Distrito Federal Brasileiro foi instalado no Planalto Central, sendo a localização do "retângulo Crulls"8 estabelecida entre 1892 e 1893 pela Comissão Exploradora do Planalto Central do Brazil, exatamente na região do divisor das águas das bacias que seguem para o norte (Araguaia-Tocantins) e para o sul (Paraná). O relevo é bastante plano e relativamente elevado, o que favoreceu os projetos de engenharia, aliado ao clima favorável (NETO, 1973).

Percebe-se que todo esse processo é a continuidade de políticas estabelecidas pelo governo brasileiro ao longo da história, iniciada com a Marcha para o Oeste. Tal projeto foi assim comentado, "A partir dos anos 30, mais claramente com o Estado Novo, o projeto de uma união civilizadora e nacionalizante para o Brasil aparece profusamente nomeado como Marcha para Oeste" (SOUZA 1997: 109). Dessa forma, a integração nacional estabeleceu uma série de metas que visaram articular o litoral e o interior brasileiro, conhecido também como sertão, de modo que ambos não se posicionassem contrários entre si, mas aliançados pela afirmação da nacionalidade.

Durante o período da Primeira República, o litoral se negava a relacionar com o sertão, argumentando que este era atrasado e arcaico (SOUZA, 1997). Por sua vez, o sertão que sofre as intolerâncias do alinhamento ao ritmo da costa, reage contrariamente a qualquer ideia de avanço litorâneo. Por isso, a afirmação da nacionalidade foi feita com a presença da autoridade estatal em todas as partes do país, de forma que a nação completou-se apenas quando o poder central articulou a sociedade e o espaço nacional a partir de 1930.

Assim, a construção da rede férrea brasileira, iniciado no governo imperial, e ampliando exponencialmente na Primeira República, ganhou novo fôlego marcadamente a partir da Era Vargas. A partir de então, as transformações no território nacional foram resultado da quebra da oposição litoral e sertão através de um controle estatal homogeneizador, materializado e operado inicialmente pela rede ferroviária nacional. A presença do Estado em todas as partes do país provocou o avanço da fronteira brasileira, do litoral rumo ao interior, com a missão de cumprir a integração nacional iniciada anteriormente.

Sobre este assunto, Estevão observa que "O projeto federal de interiorização - nas décadas de 1940 e 1950 - deixou marcas na estrutura sócio - econômica de Goiás. A construção de Goiânia havia sido parte integrante da marcha para o oeste em sua fase inicial”

\footnotetext{
${ }^{8}$ O "Retângulo Crulls" é formado pela delimitação territorial do Distrito Federal brasileiro. Recebe esse nome por causa de Luiz Crulls, chefe da Comissão Exploradora do Planalto Central do Brasil, que durante os anos de 1892 a 1894 fez o levantamento dos dados e a confecção do relatório da área. O objetivo da Comissão foi o de demarcar o local para a construção da futura capital brasileira, de acordo com o que previa a primeira Constituição Republicana.
} 
(2004: 111). A integração nacional, é, portanto, fruto de um processo histórico longo, que foi resultante, sobretudo, da eficiente logística ferroviária, que atendeu às novas cidades e capitais que surgiram.

Durante as décadas de 1930 e 1940 a cidade de Goiânia torna-se uma verdadeira "cabeça de ponte", ou seja, uma base infra estrutural para comandar a política e a economia do Estado de Goiás, mesmo ainda sem ter acesso direito a ferrovia, que somente chegaria na década de 1950. Por isso, Goiânia provocou uma antecipação das condições materiais que atraíram a ferrovia, mesmo antes da sua chegada. Assim, Goiânia foi o ponto final da rede durante anos, contribuindo para o processo de ocupação não apenas de Goiás, mas também do oeste brasileiro, uma vez que passa a reunir os elementos infra estruturais necessários para a polarização socioeconômica.

\subsection{AS FRENTES PIONEIRAS EM GOIÁS}

A partir da Marcha para o Oeste, várias etapas da incorporação do Centro Oeste brasileiro ocorreram paulatinamente, com o avanço da fronteira. A criação da nova capital de Goiás materializou um importante passo no avanço da fronteira econômica no Brasil, proporcionando condições que contribuíram para a criação de Brasília na década de 1950, cuja inauguração data de 1960. Para a melhor compreensão dos termos utilizados, propõe-se o esclarecimento do que vem a ser fronteira econômica. Waibel (1979), observa que é necessário distinguir a fronteira econômica da fronteira demográfica. Segundo ele,

\footnotetext{
A "fronteira demográfica", que limita o sertão como a mata virgem para oeste, e a "fronteira econômica", que separa o sertão a leste da região economicamente mais adiantada. (1979: 281).
}

A diferença, é que em apenas algumas áreas (trechos) se desenvolveram zonas pioneiras. O conceito de pioneiro, segundo Waibel, é mais do que fronteira. O pioneiro procura não só expandir o povoamento espacialmente, mas também, elevar os padrões de vida a partir de infraestruturas. Dentro da agricultura, nem o extrativista, nem o caçador, nem o criador de gado são aptos a constituir uma zona pioneira, mas, apenas o agricultor é capaz de transformar uma paisagem natural (mata virgem) em uma paisagem cultural e alimentar grande número de pessoas numa área pequena (WAIBEL, 1979).

Enfim, este autor afirma que para se caracterizar uma zona pioneira, é necessário além da agricultura, o aumento demográfico na região, com o consequente aumento nos preços das 
terras, o surgimento de povoados e cidades, e com isso, um espírito de arrojo e de otimismo invade toda a população. $\mathrm{O}$ autor caracteriza ainda o estágio pré pioneiro, observando a necessidade de existência de matas virgens (exceto Mato Grosso de Goiás), a presença de posseiros, grileiros e a constituição inicial de latifúndios.

De acordo com Martins (1997), o termo frente pioneira pode ser associada à fronteira econômica, e o termo frente de expansão correlacionado à fronteira demográfica. $\mathrm{O}$ significado de frente de expansão de Martins apresenta várias características do estágio prépioneiro de Waibel, como a inserção demográfica em matas virgens, a presença de posseiros e grileiros, o início da constituição de grandes latifúndios. A fronteira econômica representa a inserção do capital sobre o espaço, sendo a modernização das formas de produção, o que provoca a valorização do espaço, ou seja, ideia semelhante à frente pioneira. Para ele, frente pioneira refere-se a ideia de onde se cria o novo, nova sociabilidade, fundada no mercado e na contratualidade das relações sociais. Segundo Martins,

\footnotetext{
A frente pioneira é também a situação espacial e social que convida ou induz a modernização, à formulação de novas concepções de vida, à mudança social. Ela constitui o ambiente oposto ao das regiões antigas, esvaziadas de população, rotineiras, tradicionalistas e mortas (1997, p. 153).
}

Esta discussão sobre as fronteiras e as diversas formas de ocupação é importante para o entendimento do processo de inserção das ferrovias no Centro - Oeste brasileiro. Em outras palavras a expansão das ferrovias contribuiu para o movimento de avanço da fronteira, sendo potencializado por elas, dentro da análise geopolítica nacional, e da ótica econômica mundial.

Como já analisado anteriormente, o Estado de Goiás, à época da chegada das ferrovias ainda agregava a área do atual Estado do Tocantins. Para um melhor entendimento, será feita uma breve análise das mudanças provocadas nas diversas regiões goianas, relacionando-as às vias de acesso a partir da conjugação das propostas de regionalização de Goiás feita por Barreira (2002), do Tocantins feita por Gomes et al (2004), do Distrito Federal feito por Arrais (2004), agregando ainda o Triângulo Mineiro.

A junção de todas estas áreas forma o Brasil Central, área interna da nação que não possui fronteira com nenhum país estrangeiro, está no centro geográfico do território e conecta-se a praticamente todas as regiões do país. A ocupação do Brasil Central intensificouse a partir do final do século XIX a partir da rede ferroviária que adentrou o território goiano, e com ela, houve a paulatina dinamizada da economia das áreas adjacentes. 


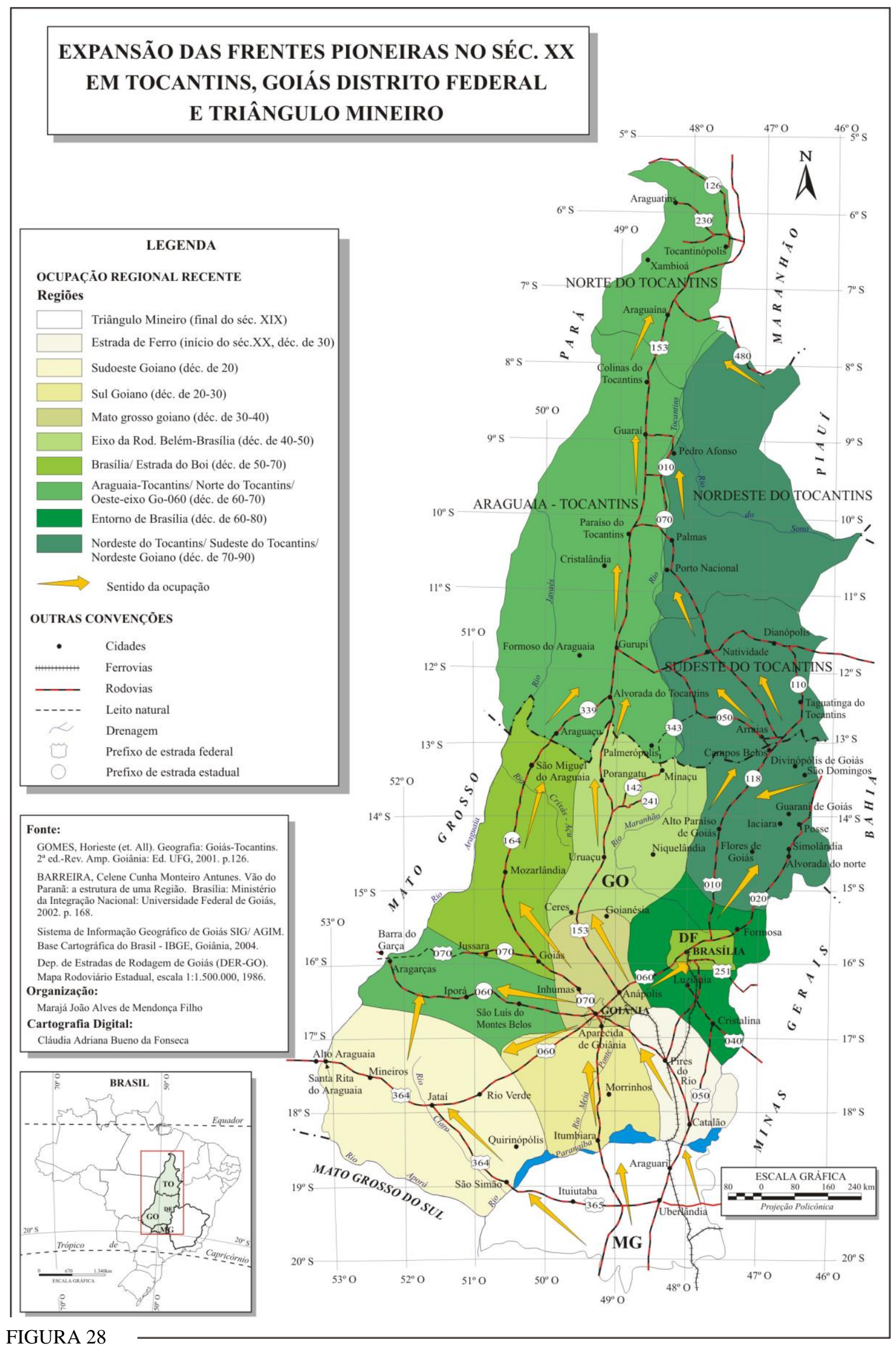

FIGURA 28

Fonte: MENDONÇA FILHO, 2005: p. 61 
Posteriormente, com a construção da rede rodoviária goiana, que passa a interagir em complementaridade à rede ferroviária, há uma progressiva evolução da economia em outras regiões goianas. A discussão do avanço cronológico das frentes pioneiras em cada região relaciona-se com a inserção das ferrovias, e mais tarde das rodovias. Dessa forma, pretende-se compreender a relação existente entre o avanço da Fronteira, o processo de regionalização do Brasil Central, e nele, Goiás, e a lógica espacial de instalação das vias de integração nacional, com destaque para a rede ferroviária.

A primeira região a ser abordada é o Triângulo Mineiro, uma vez que o avanço do café sobre o oeste paulista e a expansão das áreas agropecuárias rumo a Minas Gerais e posteriormente a Goiás, trouxeram uma intensa dinamização.

\subsubsection{Região do Triângulo Mineiro}

No final do século XIX, ocorreu a expansão dos trilhos de ferro da Companhia Mogiana até a cidade de Araguari, o que proporcionou a dinamização econômica de toda a região. Por vários anos, a Estrada de Ferro estimulou o crescimento econômico, intensificou as trocas e transformou o Triângulo em entreposto comercial entre Goiás e São Paulo. Neste período, houve grandes transformações espaciais na área, proporcionando o aumento demográfico e estimulando as atividades agropecuárias e comerciais. No entendimento de Castro,

\footnotetext{
Com a expansão da cafeicultura em São Paulo, os trilhos de ferro (Mogiana) chegaram ao Triângulo Mineiro, incentivando a exploração agrícola no entorno. Desse modo, os comerciantes puderam expandir os seus negócios para o sul de Goiás, financiando e organizando a produção, cujas relações de comércio seguiam duas direções: para o sudoeste, comercializando com Uberlândia, e para o sudeste, com Araguari (2004: 79).
}

Observa-se a grande polarização exercida pelo Triângulo Mineiro sobre o Sul Goiano, uma vez que as produções de Goiás eram comercializadas nas cidades triangulinas. O aumento dos negócios foi muito importante para a retirada de Goiás da estagnação econômica vivida após o ciclo do ouro, momento em que a população sobrevivia com uma fraca agricultura de subsistência e também, com alguns poucos rebanhos bovinos. Com a ferrovia, o triângulo passa por um grande processo de modernização, principalmente pelo fato de ser o último ponto da linha férrea durante bom tempo. Borges (2000: 12) explica que, "ferrovia foi o primeiro meio de transporte e comunicação modernos". 
Essa modernização estabelecida na região nada mais é do que o próprio avanço da frente pioneira sobre o interior da nação, o que provocou não apenas o desenvolvimento do espaço rural, mas também do espaço urbano. Algumas cidades passam a se destacar dentre as mais importantes da região do triângulo, como é o caso de Uberaba, Uberlândia e Araguari.

Os férteis solos do Triângulo Mineiro entram em um franco processo de utilização sistemática, tendo em vista que a proporcionavam um menor custo e uma boa produção. $\mathrm{O}$ posicionamento geográfico é outro importante fator, pois estabelece relações econômicas muito mais intensas com Goiás e São Paulo do que com o restante de Minas Gerais.

O Triângulo Mineiro beneficiou e principalmente, foi beneficiado pelos anos em que a linha férrea terminava em sua área. É óbvio que quando a linha férrea entra em território goiano, com a construção da Estrada de Ferro Goiás, o Triângulo continua a desenvolver, entretanto, em um ritmo mais lento. Isso ocorreu por causa da necessidade do Estado de Goiás em estabelecer relações comerciais e econômicas com o Sudeste do país. Assim, estimulou o crescimento econômico não apenas das áreas próximas à linha férrea, mas principalmente nas adjacências sua "ponta", que doravante passou a situar-se em território goiano.

Para fins de esclarecimento, o Triângulo Mineiro aqui é citado para o entendimento da relação da continuidade dos trilhos que chegam do litoral paulista até Goiás via terras mineiras. Ressalta-se também as ligações anteriormente existentes entre Goiás com o próprio Triângulo Mineiro em função de nele ter situado a última estação da ferrovia Mogiana, no final do século XIX e início do XX. Durante décadas, os produtores goianos negociavam suas mercadorias com os comerciantes do triângulo que auferiram bons lucros na intermediação entre produtores goianos e consumidores mineiros e paulistas. Ressalta-se ainda o fato de que as pessoas ao viajarem de Goiás para o litoral geralmente embarcavam nos trens que chegavam ao Triangulo Mineiro. Porém, como não faz parte de Goiás, a região do Triângulo Mineiro, embora indicada no mapa, não será contemplada com um tópico específico que aborde maiores detalhes de sua ocupação.

Para o melhor entendimento do avanço das frentes pioneiras em Goiás, as regiões e suas ocupações serão analisadas conforme a proposta de Barreira (2002). A autora estabelece a divisão do Estado de Goiás em nove regiões: Estrada de Ferro, Sudoeste Goiano, Sul Goiano, Mato Grosso Goiano, Eixo da Belém - Brasília, Estrada do Boi, Eixo da GO - 060, Entorno de Brasília e Nordeste Goiano. A primeira abordada, de acordo com a ordem cronológica dos eventos, será a região da Estrada de Ferro. 


\subsubsection{Região da Estrada de Ferro}

A chegada da Estrada de Ferro em Goiás intensifica o processo de modernização no Estado no início do século XX, e permite o avanço das Frentes Pioneiras sobre o território goiano. As mudanças iniciadas neste período serão intensas até a década de 1930. A entrada da linha férrea no território goiano representou muito mais do que integração, provocou também, um grande crescimento econômico e uma forte transformação espacial no Estado, decorrente do avanço da fronteira econômica.

A Estrada de Ferro Goiás, passou por problemas de ordem política e financeira, o que terminou por atrasar o seu cronograma de construções. Como já discutido anteriormente no capítulo um, a falta de recursos financeiros e os boicotes das oligarquias políticas do Triângulo Mineiro e também de Goiás foram os grandes responsáveis pelo atraso. Foi apenas em 1935 que a ferrovia chegou em Anápolis e somente em 1952 que alcançou Goiânia.

Mesmo assim, não impediu que Goiás fosse considerado como um espaço periférico ao café, tornando-se grande produtor de alimentos para as regiões cafeicultoras. Com a chegada dos trilhos, a agricultura na área é fortemente estimulada, se tornando a primeira região de Goiás beneficiada pela modernização e urbanização, e também, submetida a novos e dinâmicos fluxos migratórios.

Complementando o que já foi abordado anteriormente, a estrada de ferro não só vitalizou o Sudeste Goiano, mas também, se constituiu no grande corredor que trouxe a onda migratória que veio para a região. As margens da estrada foram ocupadas e várias cidades surgiram, como: Anhanguera, Cumari, Goiandira, Leopoldo de Bulhões, Ouvidor, Pires do Rio, Três Ranchos, Urutaí e Vianópolis (BARREIRA, 2002). A ferrovia além de escoar a produção, também transportava levas de migrantes rumo aos férteis espaços do Triangulo Mineiro e sul de Goiás.

Boa parte da construção dos trilhos em Goiás foi realizada no governo do presidente Getúlio Vargas. Ele defendeu a necessidade de melhorar a integração nacional devido aos eventos expansionistas da Primeira Guerra Mundial. Para isso nomeou Cassiano Ricardo como chefe do Departamento de Imprensa e Propagando. Cassiano fundamentado na tese da Marcha para o Oeste Americano de Turner (1920), desenvolve o "mito" da marcha para o oeste do Brasil, com o objetivo de atrair migrantes para o interior do território. A ferrovia goiana, foi importante para respaldar o discurso da marcha para o oeste e transportar os 
migrantes que, estimulados pelo programa governamental, proporcionaram o avanço demográfico para as áreas de fronteira, com o intuito de integrar novos espaços ao território.

O processo de legitimação da ocupação da fronteira americana através do mito da Marcha para o Oeste foi muito importante para os Estados Unidos, uma vez que foi proposta a fusão entre a "selvageria" e a "civilização". Ao cotejar a tese de Turner com a discussão de Cassiano Ricardo, aproveitou-se de uma série de analogias entre os casos americano e brasileiro. Uma dessas analogias diz respeito à transposição dos limites naturais originais dos territórios, que nos Estados Unidos agregou - se outras áreas além das 13 colônias iniciais. No Brasil, o mito da Marcha teve a mesma missão, que era estimular a migração para a fronteira, alcançando grande quantidade de pessoas que sem essa intervenção ideológica não se estabeleceria nestas regiões. Sobre esse assunto, Lenharo argumenta que,

\footnotetext{
A conquista do oeste significava para o regime a integração nacional como substrato simbólico da união de todos os brasileiros. A ocupação dos espaços ditos vazios significava não simplesmente a ocupação econômica das terras, transformada em geradora de riquezas; sua pretendida ocupação seria precedida de maneira especial, a ponto de fixar o homem na terra através de métodos cooperativos, que redimensionassem as relações sociais, de acordo com a orientação política vigente (1986, p. 18).
}

Mais do que simplesmente ocupar as terras para explorá-las economicamente, o mito da Marcha para o Oeste foi também uma ferramenta para o aumento da segurança, a partir do adensamento populacional, dentro dos planos geopolíticos de crescimento econômico e de aumento do poder nacional. A rede férrea goiana contribui significativamente para a efetivação deste projeto.

Dentre os efeitos do avanço da fronteira, um dos que mais se destacam a médio e longo prazo, foi o aumento do número de cidades. Segundo a Enciclopédia dos Municípios Brasileiros: Goiás/ Tocantins (IBGE, 1995), as cidades em Goiás e Tocantins subiram de 77 em 1950 para 179 em 1960. Será abordado no próximo tópico a região do Mato Grosso Goiano.

\subsubsection{Mato Grosso Goiano}

O incremento populacional na região do Mato Grosso Goiano é parte integrante do movimento de expansão da agricultura no Brasil, entre os anos de 1930 e 1955. Muitos agricultores mineiros vieram para Goiás cultivar diversos produtos, sendo o arroz o principal. 
A criação de Goiânia na década de 1930 foi responsável pela grande polarização sócioeconômica na região. Sua construção foi o marco de consolidação do processo de ocupação dessa área, especialmente a partir de 1940. De acordo com Monbeig, que visitou a capital na época da sua construção,

Ora, o completo êxito dos construtores de Goiânia está, sem a menor dúvida, ligado à valorização que depende das relações com os grandes centros consumidores e comerciais, vizinhos ao litoral... É verdade que já os próprios arredores de Goiânia estão povoados e que duas mil famílias rurais começam a produzir arroz, milho e feijão para o mercado local e para exportação. Além de Goiânia, que é o grande fato novo deste momento, cidades antigas redefiniram suas funções, como Anápolis, Inhumas, Itaberaí, Trindade, entre outras (1940: 84).

O avanço da fronteira rumo ao Centro - Oeste e a Amazônia não apenas foi materializado pela construção de Goiânia, mas também, utilizou a própria infra-estrutura da cidade como base logística para a criação de novas cidades e para a continuidade da expansão da frente pioneira. Ressalta-se mais uma vez que a ferrovia chegou em Goiânia apenas na década de 1950.

\subsubsection{Região Sul Goiano}

A região Sul de Goiás também recebeu grandes fluxos demográficos, principalmente nas décadas de 1920 e 1930. A ocupação da área é bastante antiga, remontando ao período da criação da Capitania de Goiás. Ela inclusive possuiu uma rota pioneira para os exploradores de ouro na fase da mineração em Goiás. Waibel destaca que: "a faixa pioneira moderna do sul de Goiás foi estabelecida não numa zona selvagem, mas numa região que foi civilizada há mais de duzentos anos" (1979, p. 161).

Com a abertura de estradas, muitas cidades foram criadas. A região Sul do estado se desenvolveu de forma articulada, como um prolongamento do sudeste brasileiro, ocupando as vastas e ricas terras existentes, com razoável interferência do estado. Cidades como Morrinhos, Itumbiara e Goiatuba, fortaleceram-se com a articulação com o Triângulo Mineiro.

$\mathrm{O}$ avanço da frente pioneira nesta região foi muito importante. A evolução econômica desta recebeu importantes contribuições das cidades triangulinas, que por sua vez eram servidas pela Estrada de Ferro Mogiana e pela Estrada de Ferro Goiás, vizinhas a região Sul Goiano. 


\subsubsection{Região Sudoeste Goiano}

Já o Sudoeste Goiano teve a dinamização do processo produtivo na primeira metade do século $\mathrm{XX}$, com a expansão da pecuária leitera e, posteriormente, com a agricultura (BARREIRA, 2002). A região é cortada pela estrada de ferro e recebe suas influências. As estradas de rodagem não pavimentadas foram implantadas paralelamente, em especial, entre 1915 e 1921, com o objetivo de servir aos municípios do Sudoeste, e seguiam para Uberabinha e a estação Mogiana. Depois de meados da década de 1940, a estrutura regional mudou, com a introdução de uma agricultura estritamente comercial em municípios como Rio Verde, Santa Helena, Quirinópolis, Paraúna, Mineiros, Santa Rita do Araguaia e Jataí. Segundo Arrais,

\footnotetext{
A partir da década de 1970, os investimentos em técnicas e infra-estrutura (transporte, comunicação, energia elétrica etc.) e a modernização agrícola, especialmente no Sul e Sudoeste do estado alteraram o papel das cidades e das regiões goianas $(2004$, p. 35$)$.
}

Com a chegada da frente pioneira na região, ocorre uma intensa dinamização da vida sócio-econômica instalada. Várias agroindústrias se instalam na área para aproveitar a aptidão natural dos férteis solos para a agricultura, criando um autêntico Complexo Agroindustrial CAI. Sorj (1980), contribui para compreensão do CAI Brasileiro ao analisar o seu papel no processo de regulamentação da produção, industrialização e consumo no Brasil. Ele observa que o CAI estabelece uma estreita ligação entre o campo e a cidade, desenvolvendo importante interdependência econômica.

A chegada da soja e a modernização da agricultura foram possibilitadas principalmente pela rodovia BR - 364 que liga o Estado do Mato Grosso com o Estado de Goiás, em direção ao Triangulo Mineiro, e consequentemente, às ferrovias e rodovias ali existentes. É importante lembrar que as melhores terras da região Sul Goiano possuem uma grande concentração fundiária, com uma agricultura altamente mecanizada, destinada à exportação e a presença de importantes agroindústrias. E para isso, uma eficiente rede de vias de transportes de diversos modais faz-se necessária para atender a grande demanda da produção.

\subsubsection{Eixo da Belém - Brasília}


O eixo da Belém-Brasília corresponde de modo geral, à área do antigo núcleo minerador colonial goiano, que posteriormente adotou uma economia agrária devido à estagnação da mineração. Após um longo período de abandono, as terras do norte voltaram a ganhar vida, principalmente com a instalação da Colônia Agrícola Nacional de Goiás (CANG) em 1941, que posteriormente deu origem à cidade de Ceres. A rodovia que liga Ceres à Anápolis, foi implantada definitivamente na década de 1950, cortando o estado no sentido longitudinal e "batizada" com o nome de Belém - Brasília.

A região é muito importante, uma vez que a BR 153 percorre seu território proporcionando uma das principais conexões entre as regiões brasileiras Sul e Sudeste com as regiões Norte e Nordeste, passando pelo Centro - Oeste brasileiro. É por essa região que passa a Ferrovia Norte Sul, e certamente será a mais beneficiada com a sua implantação.

\subsubsection{Região da Estrada do Boi}

Nesta região, a mais importante ligação entre os Estados de Goiás e Tocantins é feita pela GO 164, a qual favorece o processo de dinamização socioeconômica na área. A região conhecida como Estrada do Boi, segundo Barreira (1997), passou a ter um uso intensivo a partir de 1960, e antes deste período, predominavam as ligações regionais representadas por antigos núcleos de mineração e por navegações fluviais que não tinham função na economia estadual.

A sua ocupação ocorreu de modo intensificado nas décadas de 1960 e 1970 caracterizada por uma pecuária altamente comercial, estabelecendo importantes relações com o Estado do Mato Grosso, devido a sua posição fronteiriça. A frente que chegou na região da Estrada do Boi foi extremamente relevante para a ocupação pecuarista do Xingu. Várias cidades importantes surgiram, como São Miguel do Araguaia, Nova Crixás e Mozarlândia. A paisagem da região hoje é caracteriza por grandes pastagens e uma considerável produção agropecuária. Com a construção das novas ferrovias, como a FICO, haverá benefícios no transporte de mercadorias produzidas, com custos mais baratos.

\subsubsection{Região do Eixo da GO-060}

A região do Eixo da GO-060 foi conhecida como uma região de mineração. Após o esgotamento das jazidas, houve um considerável o processo de estagnação, que foi rompido 
apenas com a chegada da rodovia. A GO-060 estabeleceu a ligação de regiões mais dinâmicas do estado de Goiás, como Mato Grosso Goiano, Sul Goiano e Sudoeste Goiano, e também com o estado de Mato Grosso. Segundo Barreira (2002), há na região, a agropecuária moderna e a extração mineral, principalmente de níquel e de granito em escala comercial. Os núcleos importantes são Iporá, São Luiz de Montes Belos e Aragarças.

Nesta região, destaca-se a cidade goiana de Aragarças, nas margens do Rio Araguaia, que estabelece boas relações comerciais com a cidade matogrossense de Barra do Garça, situada na outra margem do rio, sendo esta uma importante articuladora econômica entre o Mato Grosso e Goiás.

\subsubsection{Região do Entorno de Brasília}

A região do Entorno de Brasília foi a que mais sofreu os impactos da inserção da nova capital federal. A região não era despovoada, haja vista que sua ocupação remonta ao ciclo da mineração, quando da criação da Capitania de Goiás. Cidades importantes foram fundadas neste período, como: Meia Ponte (1727), hoje Pirenópolis; Santa Luzia (1746), hoje Luziânia; Corumbá de Goiás (1750); Arraial dos Couros (1736), hoje Formosa; e Mestre d'Armas (1812), hoje Planaltina - DF (BARREIRA, 2002).

Com fim da mineração a região ficou estagnada até a implantação do Distrito Federal, que provocou intensa dinamização na região, seja do ponto de vista da criação de novas rodovias que integraram a região a todas as partes do Brasil, seja pela criação de novas cidades e o recebimento de grande número de migrantes. Ressalta-se que Brasília recebeu um ramal ferroviário que a conectou à Estrada de Ferro Goiás, e serve atualmente como importante via de ligação entre o Distrito Federal com a região Sudeste do Brasil. Estas vias de acesso contribuíram para que o processo de urbanização no DF fosse intenso. Consequentemente, a região do entorno do DF acabou absorvendo grande parte dos fluxos migratórios. Isso deveu-se sobretudo à rígida legislação urbana do $\mathrm{DF}$ e ao alto preço dos imóveis, o que obrigou as pessoas de menor renda a se estabelecerem nas cidades limítrofes ao DF.

Arrais (2004) afirma que a região do Entorno de Brasília é considerada a "terceira Brasília”. A primeira é a própria cidade de Brasília, a segunda é constituída pelas antigas Cidades Satélites, hoje chamadas de Regiões Administrativas. A lógica da "terceira Brasília" está vinculada ao fato das cidades situadas no Entorno do Distrito Federal estarem muito mais 
ligadas à dinâmica sócio-econômica de Brasília, do que com o próprio Estado de Goiás, da qual fazem parte. Segundo este autor,

\begin{abstract}
A mesma distância que separou essas "três Brasílias", hoje vencida pelo transporte automotivo individual e por um transporte coletivo precário e caro, permite, todos os dias, que sua população encontre formas de sobrevivência na capital do Brasil, no Plano Piloto, de onde, como sabemos, partem as decisões que podem, de uma maneira ou de outra, aproximar socialmente essas "três Brasílias" que foram propositalmente separadas (ARRAIS, 2004, p. 157).
\end{abstract}

A estreita ligação entre o Entorno de Brasília e Brasília reflete também na lógica da apropriação territorial desigual e combinada da região, facilitada pelas vias de acesso existentes. Provavelmente outros núcleos urbanos poderão ser criados no Entorno de Brasília, especialmente nas vias de acesso que ficam na região. Dentro da estratégia de articulação dos transportes em nível regional, provavelmente aproveite-se inclusive a ferrovia já existem para encompar a rede de transportes de passageiros do DF ligando o Plano Piloto às cidades de Valparaiso e Luziânia.

\title{
2.4.10 Região do Distrito Federal
}

É a região que possui um dos maiores efetivos populacionais do Brasil Central, sendo a maior Região Metropolitana do Centro-Oeste. Destaca-se também pelo maior índice de renda per capita do país. Possui uma economia terciária pujante em função da grande quantidade de órgãos públicos sediados na capital federal - Brasília, beneficiando-se pelo alto poder de consumo dos seus moradores.

Ressalta-se que um dos pontos finais da Ferrovia Centro Atlântica - FCA, é Brasília. Portanto, tal via liga a capital federal com os Estado de Goiás, Minas Gerais e São Paulo, e por ele aos principais portos do Sudeste brasileiro. Certamente as contribuições da integração ferroviária para Brasília são inestimáveis, cooperando para o transporte de suprimentos de toda ordem, necessários para o bom funcionamento da capital federal, atendendo as demandas dos seus moradores. Brasília inclusive recebeu há poucos anos a instalação de linhas de metrô, as quais cooperam para que a capital do país seja dotada de eficientes meios de transportes urbanos.

\subsubsection{Região Nordeste Goiano}


O Nordeste Goiano teve importante papel econômico no Estado, principalmente no século XIX, com a mineração e a pecuária, ambos vinculados ao Nordeste brasileiro. Com o passar dos anos, tornou-se comparativamente em relação às demais, uma das regiões mais pobres e isoladas do estado. Com a criação do Distrito Federal, várias transformações ocorreram, principalmente através dos programas de desenvolvimento regional voltados para a área de mineração, agricultura e desenvolvimento urbano. Entretanto, apenas entre meados dos anos 1970 e 1990 é que a região passa a viver um novo processo de dinamização socioeconômico. Segundo Gomes et al,

\footnotetext{
Em um passado não muito distante, anos 1980, um projeto pioneiro - Programa de Desenvolvimento Integrado Alto Paraíso - visava, entre outras coisas, conter o fluxo migratório e de demanda sobre a capital federal e integrá-la à Região Econômica de Brasília, bem como identificar, no âmbito de cada setor do governo, projetos capazes de produzir impactos regionais positivos no campo da mineração, da agropecuária, do desenvolvimento urbano, da indústria e do turismo (2004, p. 118).
}

Infelizmente muitos projetos foram abandonados em momentos de trocas de governantes, o que provocou um considerável retardo no desenvolvimento socioeconômico da região. Entretanto, vários empreendimentos estabelecidos em projetos anteriores proporcionaram a permanência contínua de investimentos na área.

A região abriga, hoje, um importante conjunto de mineração de cassiterita em São João da Aliança, de ouro em Cavalcante e um centro turístico na Chapada dos Veadeiros, na cidade de Alto Paraíso. Recentemente ocorreu a reocupação do Vão do Paranã através do desenvolvimento da pecuária (BARREIRA, 2002).

\subsubsection{Região Araguaia - Tocantins}

A região Araguaia - Tocantins possui a área com maior processo de urbanização do atual Estado do Tocantins, uma vez que a lógica de ocupação pioneira com conseqüente urbanização acelerada, iniciou em meados de 1960 com a construção da BR 153. Várias cidades têm surgido ao longo do grande corredor de integração nacional, caracterizadas do ponto de vista sócio-econômico na agropecuária tradicional na vertente do Rio Tocantins, e na agropecuária moderna na vertente do Rio Araguaia.

A Belém - Brasília foi, e ainda é, um importante elemento dinamizador da região, pois constituiu o principal eixo de integração norte sul da marcha para o oeste, e também da atual economia brasileira. Após o prolongamento do eixo da Belém - Brasília em território 
tocantinense, observou-se o desenvolvimento de cidades importantes como Gurupi e Araguaína. A BR 153 serve ainda de eixo de contato com a Capital Palmas, construída a partir de 1989, com a criação do Estado do Tocantins. Destacando a importância da rodovia, Gomes et al explica que,

\begin{abstract}
Vista do alto, ela nada mais é que o grande corredor formado pela rodovia de integração nacional mais importante do Brasil - a Belém - Brasília. Foi aqui que se verificou o mais espetacular processo de ocupação pioneira e de urbanização acelerada já registrados no Centro-Oeste do Brasil nos últimos quarenta anos. Podese afirmar que a rodovia é "mãe" direta e indiretamente de mais de um terço das cidades tocantinenses atuais (2004, p. 117).
\end{abstract}

É certo que a região vive um dos maiores processos de desenvolvimento, o que lhe confere uma grande importância econômica para o Tocantins.

\title{
2.4.13 Região Norte do Tocantins
}

É a região de meio natural mais rico e diversificado do Tocantins, com a cidade mais importante do Estado - Araguaína - e constituiu uma das mais importantes zonas de povoamento da Amazônia. Os férteis solos existentes na região atraíram vários migrantes, estes, originados especialmente do Estado do Maranhão. Sua ocupação histórica é bastante antiga, uma vez que o Rio Tocantins constituiu um importante corredor de conexão com o litoral, favorecendo o surgimento de alguns povoamentos ainda no século XIX.

As lutas de independência, as rebeliões do começo do segundo reinado e as secas periódicas no Nordeste determinaram uma concentração excepcional de população no extremo norte do Tocantins não apenas no século XIX, mas também no início do século XX. A partir de 1960, com a abertura da Belém-Brasília, a BR - 153, e a implementação de políticas públicas que visavam a integração, ocorreu o fortalecimento da região. Como em outras regiões do Estado do Tocantins, a BR 153 é considerada a "criadora" da maioria das cidades, e a responsável pelo desenvolvimento das já existentes. De acordo com Gomes et al,

Até o início dos anos 60, quando da chegado da rodovia Belém - Brasília, constavase aí apenas meia dúzia de cidades: Araguaína, então uma pequena povoação; Tocantinópolis, que dividia com Porto Nacional e Gurupi o status de maior centro urbano tocantinense, mas abrigando, como as outras, uma população que mal chegava a cinco mil habitantes, se constituía na mais importante cabeça-de-ponte para a ocupação pioneira de toda a zona situada entre os rios Araguaia e Tocantins, cujo "bico" se insinua na Amazônia; Araguatins, Itaguatins, Babaçulândia, Filadélfia e Xambioá, que, com Araguaína, não passariam de pequenas aglomerações praticamente isoladas do resto do estado, não fossem elas ribeirinhas dos dois 
grandes rios. Passados 42 anos da chegada da grande rodovia, a região abriga um terço de todas as cidades do estado do Tocantins $(2004,116)$.

A região é a mais importante do ponto de vista sócio-econômico no Estado do Tocantins e polarizam boa parte de arrecadação tributária do Tocantins. Por ter um posicionamento estratégico em função da proximidade com os estados do Pará, do Maranhão e da Bahia, acaba privilegiada pelas trocas comerciais feitas entre tais entes federativos.

\subsubsection{Região Nordeste do Tocantins}

É considerada como a região mais desassistida de todo o Estado do Tocantins, especialmente do ponto de vista infra-estrutural. Entretanto, é a mais importante geopoliticamente devido à presença da capital estadual - Palmas. A construção da capital do Tocantins nesta região foi muito importante para a retomada do seu desenvolvimento, que estava estagnado desde o fim do século XIX, quando houve um litígio com a Bahia por causa da riqueza natural do látex da mangaba ali existente.

No final dos anos 1980, a região começou a viver um processo de crescimento econômico que revitalizou o papel histórico - geográfico da cidade de Porto Nacional, e que também, começou a despertar o potencial ecoturístico de outras áreas. De acordo com Gomes et al,

\footnotetext{
Seu potencial turístico é inigualável, dada a beleza insólita que caracteriza o seu meio natural. A região do Jalapão, um autêntico deserto, não só pela maneira rarefeita como a população e as cidades aí se distribuem no espaço, mas também por suas próprias características geológicas (coberturas paleomesozóicas que constituem a Bacia do Tocantins àquela altura) e geomorfológicas (ela faz parte dos imensos patamares do São Francisco, cobertos por uma vegetação rala sobre solos francamente arenosos, com forte predisposição à erosão e à desertificação) (2004, p. $115)$.
}

A partir do momento em que a região possui as áreas mais sensíveis do ponto de vista da ocupação agropecuária, o ecoturismo surge como alternativa para o desenvolvimento econômico e a preservação ambiental. A possibilidade de aliar as poucas áreas de solos propícios à agropecuária, contribuem para o abastecimento das indústrias que aos poucos se instalam no Estado para atender a demanda da crescente população da cidade de Palmas e outras cincunvizinhas. A ferrovia Norte Sul, que passa por esta região tem o papel de cooperar para a transporte de produtos oriundos dos empreendimentos já existentes, e também, dos que futuramente serão instalados. 


\subsubsection{Região Sudeste do Tocantins}

Já foi uma das regiões mais ricas do Estado, uma vez que se encontra sobre o antigo eixo da mineração do século XVIII, motivo que lhe permitiu a existência de povoamentos e urbanizações antigos. Com o asfaltamento das vias que substituíram as antigas estradas reais a partir de 1980, a região começou a sair de um longo período de estagnação vivido desde o fim do ciclo minerador. Possui importantes cidades como Dianópolis, Natividade, Paranã e Arraias, as quais estão vivendo a ocupação dos seus férteis fundos de vale pela agropecuária modernizada.

A região seria beneficiada pelo então Governador Mauro Borges a partir da proposta de criação do Combinado Agrícola de Arraias em 1960. O mesmo não teve continuidade por causa da intervenção dos governos pós 1964. Pelo prisma geopolítico a região possui uma considerável importância estratégica, uma vez que está situada entre Palmas e Brasília, e ainda possui importantes vias de comunicação entre a capital tocantinense e a região Nordeste do Brasil. Esta região passou a ser beneficiada com a conclusão do trecho da ferrovia Norte Sul que liga as redes férreas do Nordeste, no estado do Maranhão, com a cidade goiana de Anápolis, no estado de Goiás, e de lá, via ferrovia Centro Atlântica, chegar até o litoral brasileiro.

Ao analisar as transformações ocorridas no território goiano a partir do avanço das frentes pioneiras, evidencia-se a força das vias de acesso, sejam as ferrovias, e mais tarde, as rodovias, como agentes dinamizadores desse processo. O nível de intervenção e transformação da paisagem está intimamente ligada com a intensidade da presença das infraestruturas logísticas de circulação, ao mesmo tempo em que, por outro lado, manifestam a pujança econômica de tais áreas. 


\section{FERROVIA NORTE SUL NO TERRITÓRIO GOIANO: PERSPECTIVAS E IMPLICAÇÕES}

Este capítulo aborda as perspectivas e implicações da Ferrovia Norte Sul no território e na economia de Goiás. Para isso analisou-se a forma e o posicionamento das ferrovias no território, as modificações demográficas, os incrementos econômicos e a articulação territorial via ferrovias em Goiás. Ressalta se que o papel principal da Ferrovia Norte Sul será possibilitar uma grande espinha dorsal logística de aço, que ligará todas as malhas férreas do país e que possibilitará a intensificação da modernização econômica da nação e menores custos do frete.

\subsection{A FERROVIA NO TERRITÓRIO}

Embora seja uma ferrovia iniciada na década de 1980, a Norte Sul passou por várias paralizações nas obras. Nos últimos anos, houve um bom ritmo na sua construção, de modo que seus trilhos atingiram o solo goiano, propiciando importante ligação com a Ferrovia Centro Atlântica em Anápolis. O trecho goiano da ferrovia Norte - Sul que terminava em Anápolis, principal cidade da ferrovia, foi estendido.

Com o aumento da ferrovia em direção ao sudoeste de Goiás, serão contempladas com o incremento na circulação outras cidades de Goiás como: Acreúna, Brazabrantes, Cachoeira Alta, Campo Limpo de Goiás, Campestre de Goiás, Damolândia, Edéia, Goianira, Indiara, Jandaia, Nerópolis, Nova Veneza, Ouro Verde de Goiás, Paranaiguara, Quirinópolis, Rio Verde, Santa Bárbara de Goiás, Santa Helena, Santo Antônio de Goiás, São Simão, Trindade e Turvelândia.

Da divisa do Estado do Tocantins até a cidade de Uruaçu (GO) são 220 quilômetros. De Uruaçu até Anápolis são 280 quilômetros, enquanto que de Anápolis até Rio Verde haverá mais 300 quilômetros e de Rio Verde (GO) até Rubinéia (SP) outros 380 quilômetros. Já o trecho que parte de Anápolis (GO) até a cidade de Estrela D’Oeste (SP) é conhecido como “Tramo Sul” e terá um total de 680 quilômetros, sendo 494 em território goiano, 105, 7 quilômetros em Minas Gerais e 66,2 quilômetros em São Paulo. O objetivo é passar por acentuadas regiões produtoras de grãos e cana de açúcar, além de outros produtos industrializados na região de Quirinópolis (GO). A figura 29 mostra os detalhes do trecho goiano da Ferrovia Norte Sul. 
Figura 29 - Trecho Goiano da Ferrovia Norte Sul.

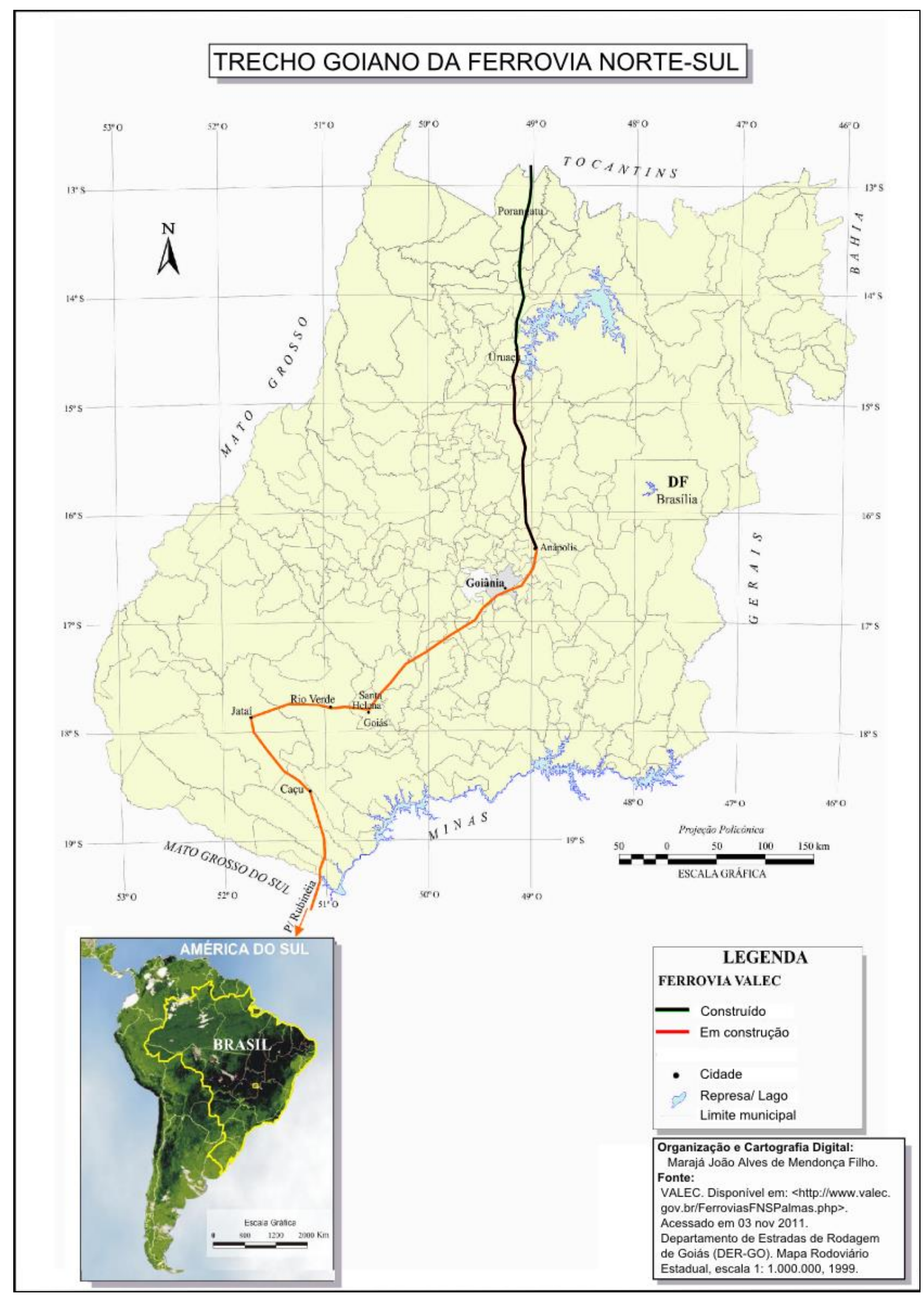


No trecho estão previstos dois pátios de carregamento de grãos e de produtos diversos, sendo um em Santa Helena de Goiás (GO) e outro em São Simão (GO) (VALEC, 2011). A integração ferroviária nacional será possível a partir das ferrovias VALEC, localizadas em Goiás. A mais importante das ferrovias da VALEC é a Norte Sul, com considerável extensão em terras goianas. Para se ter uma ideia, da divisa do Estado do Tocantins até a cidade de Uruaçu (GO) são 220 quilômetros. De Uruaçu até Anápolis são 280 quilômetros, enquanto que de Anápolis até Rio Verde haverá mais 300 quilômetros e de Rio Verde (GO) até Rubinéia (SP) outros 380 quilômetros.

Neste sentido, evidencia-se que o traçado das ferrovias foi estratégico, pois permitirá uma eficiente logística de transportes entre as áreas produtoras de Goiás com todo o país, e também, com os principais portos brasileiros, e por eles, o acesso ao mercado internacional. Com a expansão da malha ferroviária em território goiano a partir da conclusão da ferrovia Norte - Sul, transformações espaciais consideráveis têm ocorrido, principalmente do ponto de vista econômico, uma vez que Goiás tornou-se o novo grande entroncamento logístico do país.

De acordo com Santos "Ao lado da busca pelas empresas dos melhores sítios para sua instalação, há, também, pelos próprios lugares, uma procura às vezes escancarada de novas implantações e um cuidado por reter aquelas já presente (...) é a guerra dos lugares” (2002, p. 248). Espera-se que a estratégica ocupação do território via ferrovias e a produção gerada sobre ele sirva para atender os interesses sociais e econômicos. Sobre este assunto, Santos analisa que "O espaço racional supõe uma resposta pronta e adequada às demandas dos agentes, de modo a permitir que o encontro entre a ação pretendida e o objeto disponível se dê com o máximo de eficácia” (2002, p. 300).

Por isso, a ferrovia Norte-Sul juntamente com as já existentes e operadas pela FCA, integrarão os Distritos Industriais do Estado de Goiás aos grandes mercados de consumo, através de pátios de embarque e desembarque que foram estrategicamente posicionados. Os pátios de embarque em Goiás estão localizados nas cidades de Porangatu, Uruaçu, Campinorte, Santa Izabel, Jaraguá, Ouro Verde, Anápolis, Goiânia, Vianópolis, Pires do Rio, Roncador, Catalão, Santa Helena e São Simão.

Tais pátios atenderão os Distritos Industriais goianos, os quais estão situados nas cidades de São Miguel do Araguaia, Porangatu, Uruaçu, Campinorte, Goianésia, Ceres, Rubiataba, Itapuranga, Cidade de Goiás, Jussara, Anicuns, Inhumas, Goianira, Anápolis, Abadiânia. A figura 30 indica os Distritos Industriais de Goiás. 


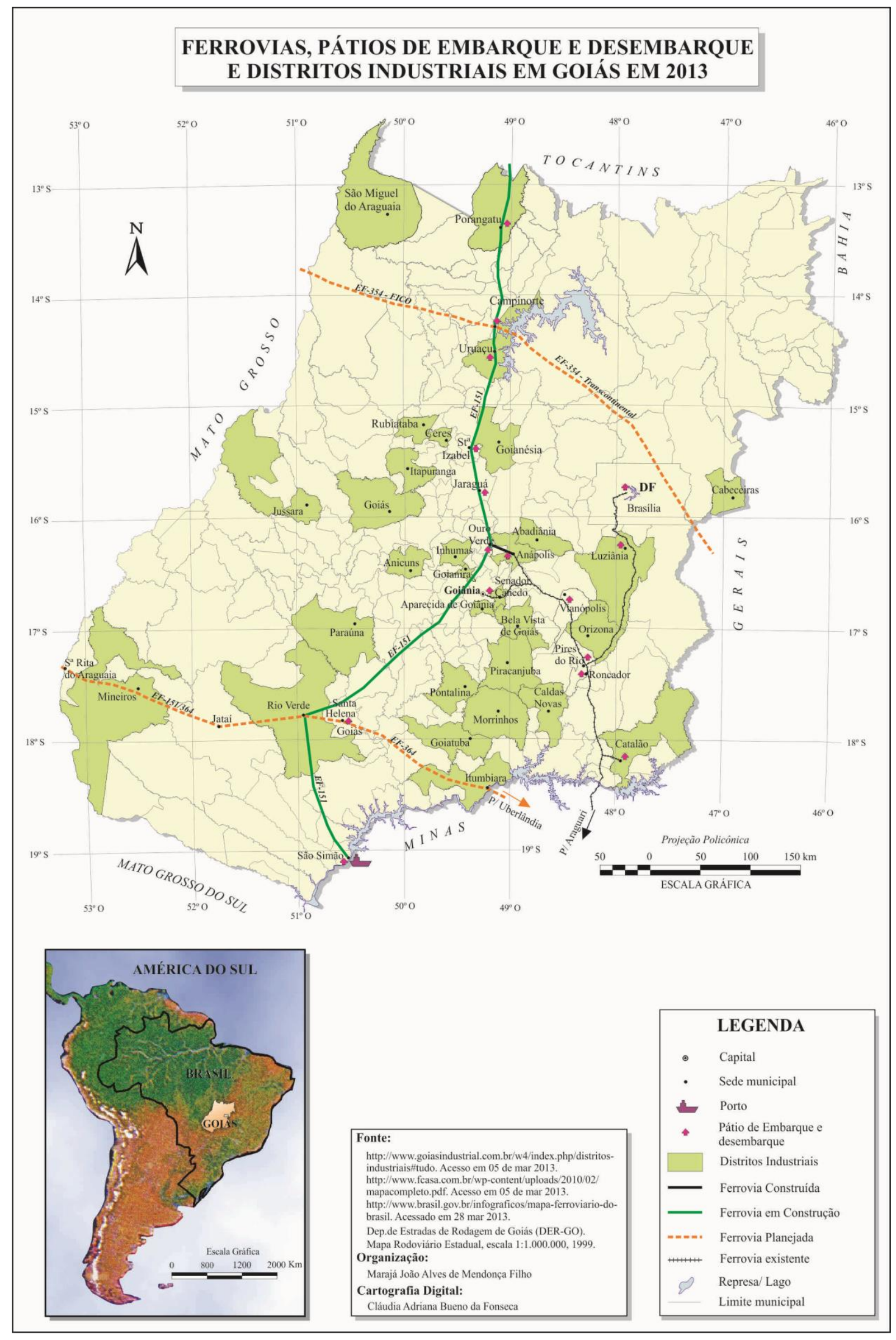


Além dos pátios já citados, existem ainda os de Senador Canedo, Aparecida de Goiânia, Bela Vista, Orizona, Luziânia, Cabeceiras, Pontalina, Caldas Novas, Piracanjuba, Morrinhos, Goiatuba, Itumbiara, Rio Verde, Paraúna e Mineiros. Assim, chega-se ao entendimento de que a produção econômica no território é uma realidade, principalmente ao analisar as ferrovias brasileiras e mais especificamente aquelas que "cruzam" o território goiano.

O trecho goiano é apenas uma parte da grande via férrea. Para se ter uma ideia, na ferrovia Norte Sul, o trecho ferroviário ligando as cidades maranhenses de Estreito e Açailândia está concluído e em operação comercial desde 1996. O volume de carga transportado pelos trilhos da ferrovia tem alcançado anualmente um aumento expressivo, atingindo o patamar de 8,9 milhões de toneladas desde o início da operação comercial até julho 2012.

Segundo dados da Agência Nacional de Transportes Terrestres - ANTT, os principais produtos transportados são soja e farelo, areia e minério de ferro. Ressalta-se também a redução com os custos dos transportes e a diminuição do consumo de combustíveis ao destinar boa parte do transporte de cargas para o modal ferroviário, ao invés de utilizar o modal rodoviário, cujos ônus são mais caros. Além disso, provavelmente diminuirá os índices de acidentes nas estradas. Em relação aos custos financeiros do frete, estima-se uma economia média de $30 \%$ ao substituir o modal rodoviário pelo ferroviário.

Já a quantidade de carga, chegou a 1.424 milhões de toneladas úteis (tu) em 2008, 1.639 milhões tu em 2009, 2.012 milhões tu em 2010, 2.562 milhões tu em 2011 e 1.281 milhões tu em 2012 (até o mês de julho). A frota de locomotivas em 2011 chegou a 12, enquanto que os vagões em circulação chegaram a 577. A extensão da malha ferroviária da Norte Sul até setembro de 2011 chegou a 720 quilômetros. Em 2014 a ferrovia Norte Sul completou 1.579 km de trilhos construídos - ligando Açailândia - PA até Anápolis - GO - dos quais 719 km estão em operação - no trecho entre Açailândia e Palmas - TO (ANTT, 2013).

Com o aumento da ferrovia em direção ao sudoeste de Goiás, serão contempladas cidades de outros estados. Com os novos trechos, a ferrovia Norte Sul terá mais $682 \mathrm{~km}$ até a cidade de Estrela do Oeste - SP, de lá até Panorama - SP outros 264 km, e desta cidade até Rio Grande - RS mais $1.731 \mathrm{~km}$. Quando pronta, a ferrovia Norte Sul terá $4.733 \mathrm{~km}$ de extensão. A figura 31 detalha os trechos da ferrovia Norte Sul, de acordo com a unidade da federação e o estágio da construção. 
Figura 31 - Diagrama Unifilar da Ferrovia Norte Sul - FNS

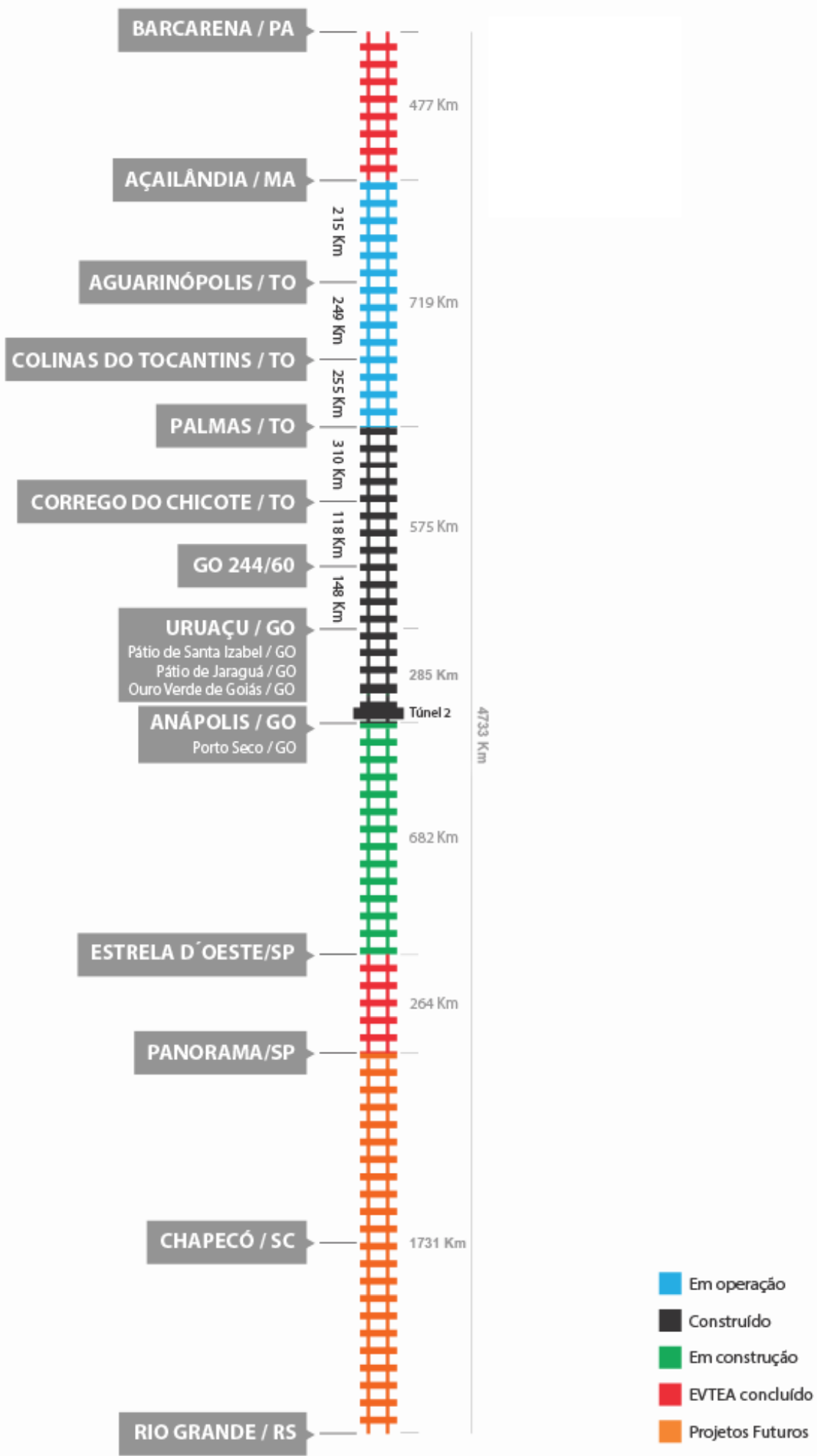

Fonte: VALEC, 2015. 
Todo o planejamento espacial dessa ocupação visa à reestruturação da produção econômica no país pois facilitará a movimentação da produção, o que provocará intensas mudanças na paisagem nacional, e consequentemente, goiana. De acordo com Santos "Não basta, pois, produzir. É indispensável pôr a produção em movimento. Em realidade, não é mais a produção que preside à circulação, mas é esta que conforma a produção" (2002, p. 275).

Com o incremento na circulação, novos empreendimentos estão sendo instalados em Goiás. Por isso o número de habitantes neste estado tem aumentado, uma vez que muitos trabalhadores têm migrado em busca dos novos empregos e com isso melhores condições de vida. Observa-se ainda um processo crescente de instalação de indústrias em Goiás, substituindo aos poucos a produção de produtos primários, como grãos e minérios, por produtos com maior valor agregado, o que é positivo para o estado. Isso é facilmente perceptível ao analisar o crescimento da população goiana, e também da sua urbanização, entre 1991 e 2010.

Este fato também gera novos investimentos no ramo educacional, aumentando a oferta de empregos e renda. Isso estimulará os setores público e privado do estado de Goiás em investir em educação de qualidade, e também, em centros de pesquisa para a geração de ciência e tecnologia. Tal situação tem motivado a instalação de um maior número de empresas e outros empreendimentos econômicos, resultando em crescimento populacional, fruto do recebimento de fluxos migratórios. Observe os dados da tabela 1.

Tabela 1 - População residente, segundo as unidades da federação - 1991/2000/2010

\begin{tabular}{|c|c|c|c|c|c|c|c|}
\hline & \multicolumn{2}{|c|}{1991} & \multicolumn{2}{|c|}{2000} & \multicolumn{2}{|c|}{2010} & \multirow{2}{*}{$\begin{array}{c}\text { Variação } \\
(\%) \\
1991 / 2010\end{array}$} \\
\hline & Habitantes & Part (\%) & Habitantes & Part (\%) & Habitantes & Part (\%) & \\
\hline Brasil & 146.825 .475 & 100,00 & 169.799 .170 & 100,00 & 190.755 .799 & 100,00 & 29,92 \\
\hline Centro Oeste & 9.412 .242 & 6,41 & 11.616 .745 & 6,84 & 14.058 .094 & 7,37 & 49,36 \\
\hline Goiás & 4.018 .903 & 2,74 & 5.003 .228 & 2,95 & 6.003 .788 & 3,15 & 49,39 \\
\hline
\end{tabular}

Fonte: IBGE apud SEGPLAN (2011, P.5)

Com base na tabela quatro, observa-se que em 1991 a população goiana era de 4.018.903 habitantes, em 2000 somava 5.003.229 habitantes e em 2010 chegou a 6.003 .788 habitantes, representando $3,15 \%$ do total nacional. Com relação ao crescimento populacional, de 1991 para 2010 houve um acréscimo de 49,39\%, estando bem acima da média nacional que foi de 29,92\% no mesmo período. O gráfico 4 indica a evolução. 
Gráfico 4 - Saldo Líquido Migratório - 2004 / 2009 (mil hab.)

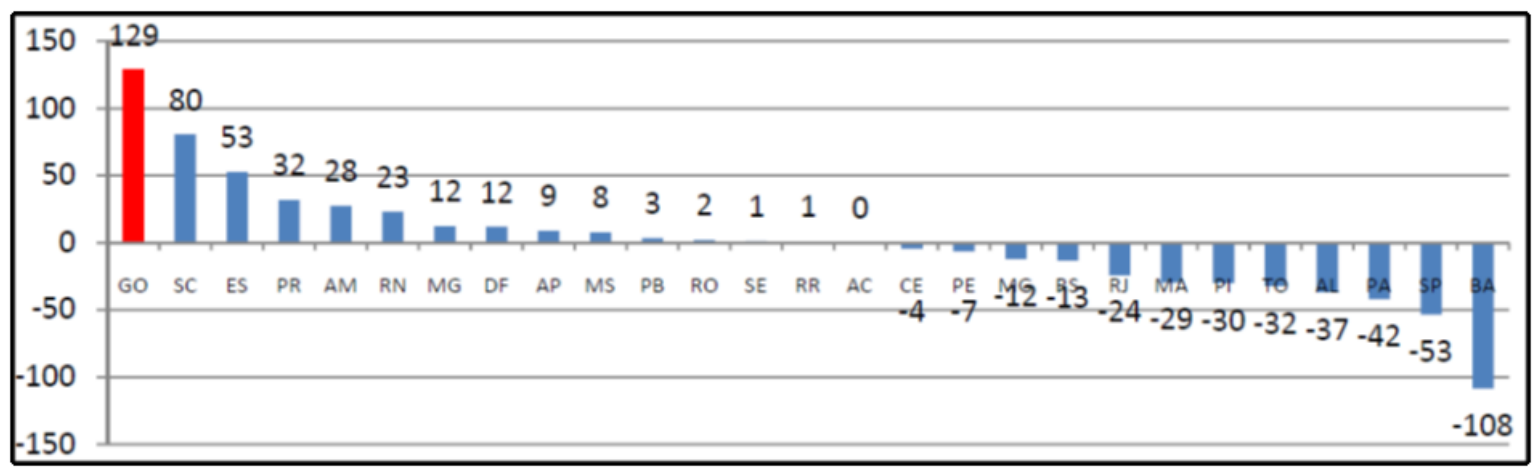

Fonte: IBGE apud SEGPLAN 2011.

Em relação aos demais estados brasileiros, considerando o período de 2004 a 2009, Goiás foi a unidade da federação com maior saldo migratório do Brasil, com um total de 129 mil habitantes, valor maior que do estado de São Paulo. Além disso, Goiás também ficou na frente de outros importantes estados como Santa Catarina, Espírito Santo, Rio Grande do Norte, Minas Gerais, Amazonas, entre outros. Percebe-se que mais da metade dos estados brasileiros apresentaram saldo líquido migratório positivo. Para se ter uma ideia o estado de Santa Catarina, que foi segundo colocado, chegou a receber 80 mil habitantes entre 2004 e 2009, enquanto Goiás incorporou 129 mil migrantes. Houve também um incremento na urbanização goiana. O gráfico 5 mostra os índices.

Gráfico 5 - Evolução da população rural e urbana - Goiás - 1991/ 2000/ 2010

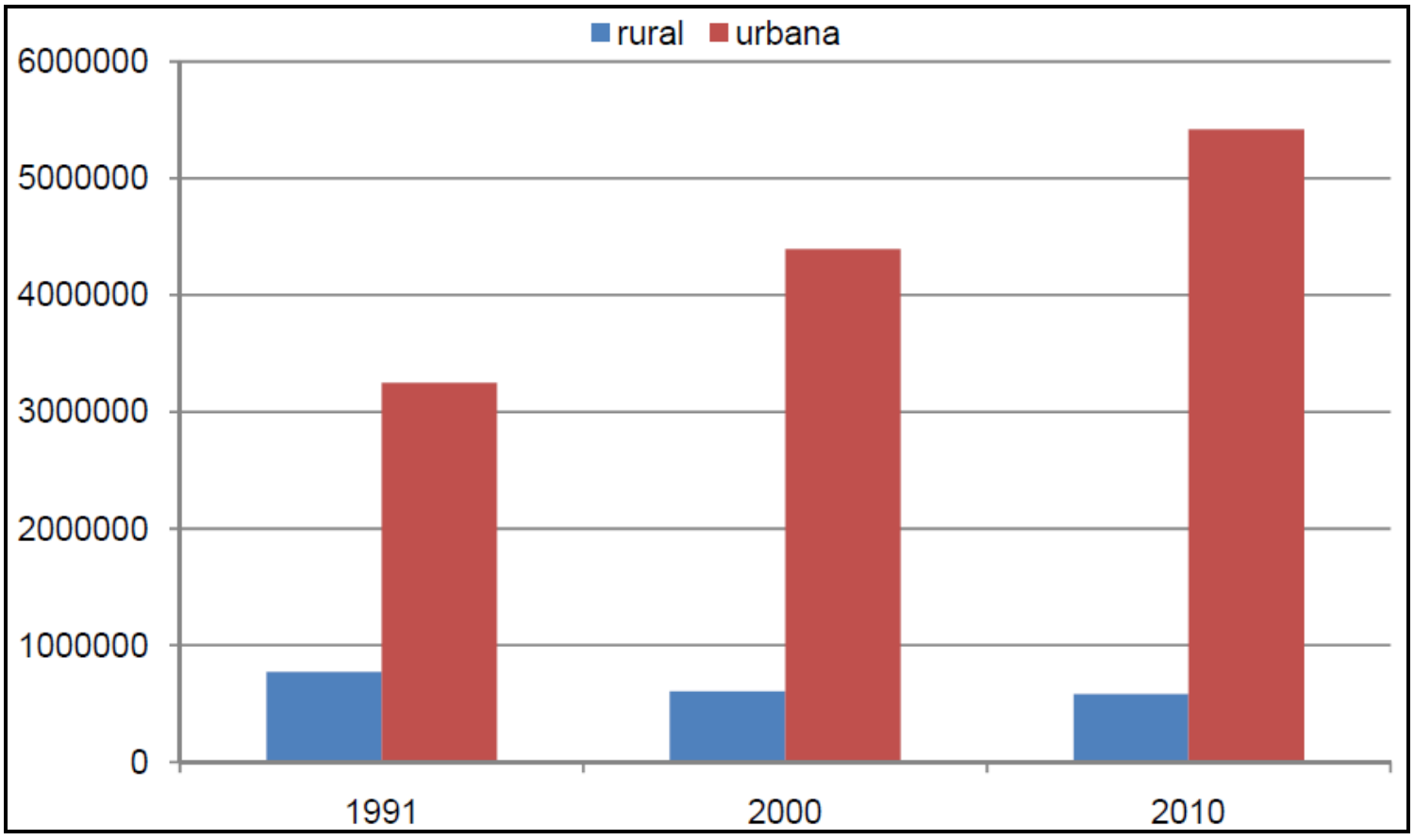

Fonte: IBGE apud SEGPLAN (2011, p.23). 
Ou seja, cada vez mais os cidadãos que residem em Goiás estão morando em cidades, e não no campo. Isso se deve ao constante aumento da tecnificação da economia goiana, diante da modernização do campo, que demanda cada vez menos mão de obra, e o crescimento do número vagas nas indústrias e serviços situados nas cidades. Com isso será necessário também melhorar a qualificação dos trabalhadores goianos com o objetivo de prepará-los para melhores cargos e funções, caso contrário correrão o risco de ficarem desempregados por falta de qualificação. Os novos usos do território goiano resultaram na necessidade de novos planejamentos e infraestruturas para atender tais demandas. Segundo Santos,

\begin{abstract}
O uso do território pode ser definido pela implantação de infraestruturas para as quais estamos igualmente utilizando a denominação sistemas de engenharia, mas também pelo dinamismo da economia e da sociedade. São os movimentos da população, a distribuição da agricultura, da indústria e dos serviços, o arcabouço normativo, incluídas a legislação civil, fiscal e financeira, que, juntamente com o alcance e a extensão da cidadania, configuram as funções do novo espaço geográfico (2001, p. 21).
\end{abstract}

Por outro lado, há algumas preocupações com o novo processo de ocupação territorial, como a grande degradação ambiental já sofrida pelo cerrado goiano estimulada pela expansão agropecuária e industrial. Certamente tais impactos deverão intensificar-se em função do crescimento populacional e urbano, o que pressionará o ambiente para o fornecimento de alimentos, água e outras matérias primas, além dos possíveis problemas advindos da contaminação de mananciais hídricos e dos solos.

Desta forma, a preocupação governamental é em incrementar uma política de transportes que aproprie intensivamente das áreas de cerrado do país com o objetivo de promover o crescimento econômico e evitar a degradação do meio. Obviamente tal estratégia poderá causar consideráveis danos, caso medidas de proteção ao ambiente não sejam empregadas. Chama a atenção também à ideia de melhorar a qualidade de vida da população via ocupação diferenciada do território a partir de uma estratégia de aumento da produção. Veja os propósitos da VALEC em relação a ferrovia Norte Sul:

\footnotetext{
A articulação de diferentes ramos de negócios proporcionada por sua implantação está contribuindo para o aumento da renda interna e para o aproveitamento e melhor distribuição da riqueza nacional, a geração de divisas e abertura de novas frentes de trabalho, permitindo a diminuição de desequilíbrios econômicos entre regiões e pessoas, resultando na melhoria significativa da qualidade de vida da população da região (VALEC, 2011).
}

$\mathrm{Na}$ prática isso deveria evidenciar-se a partir de investimentos em educação, saúde, segurança e infraestrutura para a população. Sem dúvida, a integração econômica poderá 
contribuir para a diminuição das desigualdades sociais a partir da distribuição das riquezas entre as regiões. Neste sentido, as ferrovias poderiam contribuir para a sociedade brasileira caso os benefícios produzidos em sua zona de influência fossem efetivamente destinadas a solução de problemas da sociedade, inclusive as desigualdades.

Várias oportunidades foram criadas com a introdução de novos fluxos de capitais, trazendo consigo boas expectativas quanto a melhoria na qualidade de vida da sociedade goiana. Por outro lado, é preciso impedir que recursos sejam concentrados nas mãos de apenas poucas pessoas, o que aumentaria a miséria e os conflitos sociais, piorando a violência e a infelicidade. É preciso lembrar que na produção econômica, o território deve ser, a priori, um elemento que atenda às necessidades básicas de sobrevivência das sociedades, e não apenas transformado em um agente exclusivamente reprodutor do lucro.

Chama-se a atenção é para que tais benefícios sejam socializados, mediante a correta e eficiente aplicação dos impostos, para todos os membros da sociedade, entendendo que o cidadão deve ser sujeito da evolução de qualquer nação, e não ser simplesmente objeto a ser empregado para isso. Portanto, é necessário que boa parte dos recursos arrecadados seja destinado para escolas, universidades, centros de pesquisas, saneamento básico, segurança, saúde, dentre outras demandas sociais.

Isso será necessário para que a nossa nação não seja conhecida apenas pelo seu PIB, mas, sobretudo pelo seu IDH, este sim, um referencial mais próximo do ideal de desenvolvimento da pátria. Na medida em que se integrar não apenas os territórios, mas também os cidadãos destes espaços à economia e a uma condição digna de vida, aí sim, haverá um efetivo desenvolvimento. Para isso a ferrovia Norte - Sul deverá contribuir na criação de melhores condições para o desenvolvimento social, não apenas do estado de Goiás, mas para todas as suas regiões de influência, convertendo racionalmente o território em condições de produção da dignidade humana.

\subsection{A ARTICULAÇÃO TERRITORIAL}

A articulação territorial foi feita incialmente pela junção do eixo rodoviário com o ferroviário, criando zonas de influência econômica e articulando a circulação no território. A figura 32 detalha a integração do Brasil Central antes da ferrovia Norte Sul. 
Figura 32 - Eixos logísticos anteriores a Ferrovia Norte Sul e o surgimento de cidades em Goiás e Tocantins.

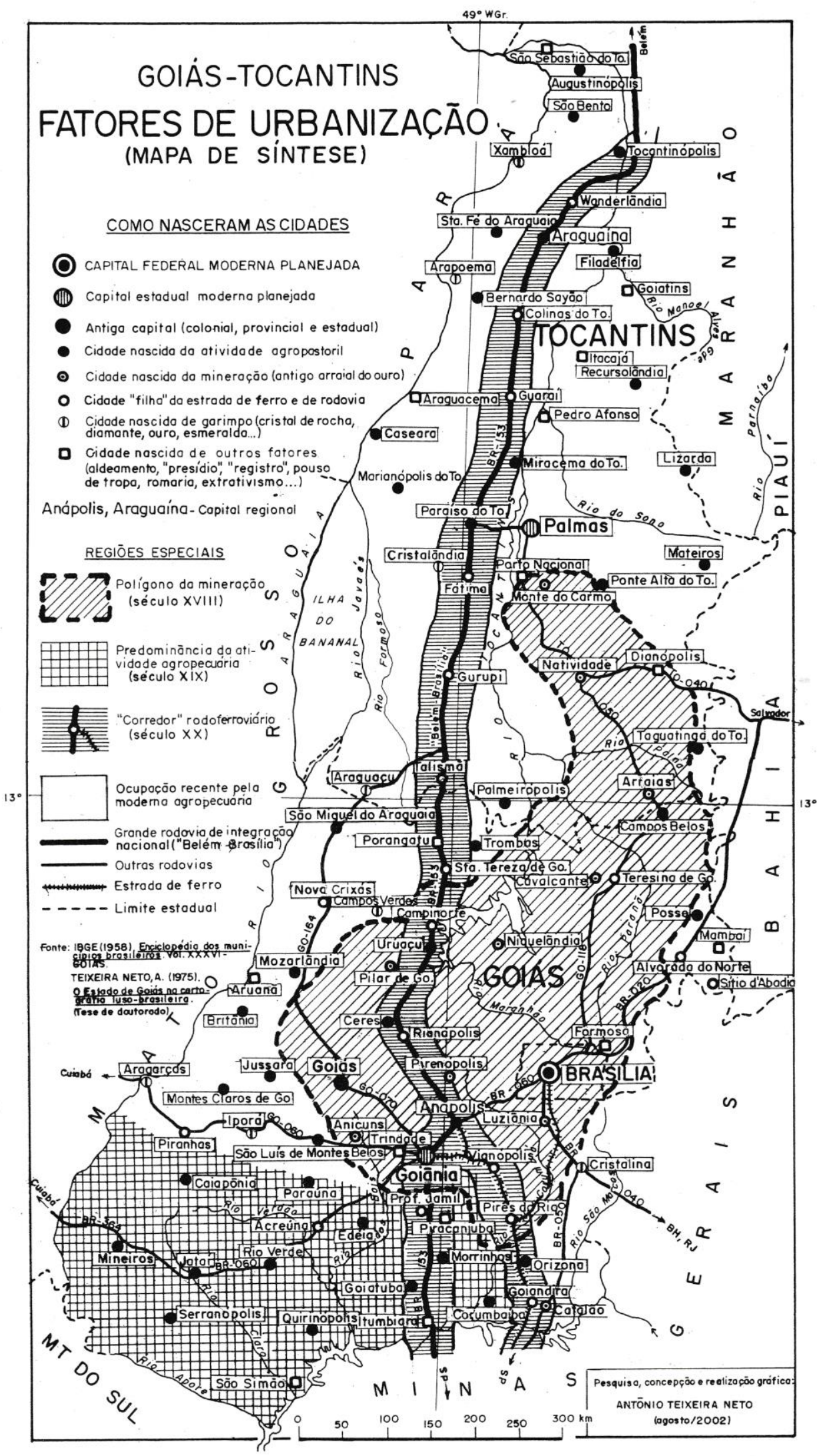

Fonte: Gomes, 2004, p. 93. 
A força de atração que antes era baseada na economia mineradora passa a ser fundamentada na economia agropecuária, e mais recentemente no agronegócio. Tais eixo são tão marcantes que estimularam a criação de várias cidades. Agora, a articulação predominará via ferrovias, o que representará uma grande mudança no cenário nacional. As ferrovias, passam a contribuir, de forma especial, com o transporte da produção do Sudoeste Goiano, juntamente com o Nordeste de Mato Grosso do Sul, o Sul de Mato Grosso, parte do Triangulo Mineiro e o interior de São Paulo, que constituem o polígono da soja, responsável por grande parte da produção desta commoditie.

As ferrovias foram estendidas de modo a disponibilizar um modal de transporte mais barato e eficiente a tais áreas. Mais tarde, com o avanço da cultura da soja no Estado de Mato Grosso e Rondônia, houve a necessidade de planejar o aumento dos trilhos para atender os novos fronts. Em Goiás, as novas vias possibilitaram o aumento do número de cidades, com uma concentração nas margens das ferrovias e rodovias, sendo estas as "genitoras" territoriais de muitos núcleos urbanos goianos, e atualmente, tocantinenses.

O eixo logistico do interior do Brasil, situado ao longo da BR-153, até então era de predominancia rodoviária, e apenas recentemente é que passou para ferroviária, com a contrução da Norte Sul. A capacidade de artilação territorial das redes logísticas marca a paisagem geográfica e materializa o poder de transformação da economia. Por ser recente, não será feita uma regionalização das influências da ferrovia Norte Sul no Brasil Central, como foi feita das ferrovias da FCA (antigas Mogiana e Estrada de Ferro Goiás), mas uma análise das áreas por onde passa, indicando as principais cidades e zonas de influência.

Quando totalmente concluída, o tamanho do trecho da Ferrovia Norte-Sul em Goiás será de $991 \mathrm{~km}$, dos quais $500 \mathrm{~km}$ foram inaugurados no dia 22 de maio de $2014^{9}$. O trecho inaugurado está compreendido entre as cidades de Palmas - TO e Anápolis - GO somam 855 km, dos quais 355 em território tocantinense. O início das operações da Ferrovia Norte Sul em Goiás em 2014 possibilitou a integração das malhas ferroviárias do Sul e Sudeste, com as

\footnotetext{
9 A Presidenta da República, Dilma Rousseff, acompanhada do Ministro dos Transportes, César Borges, inaugurou trecho de $855 \mathrm{~km}$ da Ferrovia Norte-Sul compreendido entre as cidades de Palmas/TO e Anápolis/GO. "Aqui se pode conectar todo o Brasil com o sistema ferroviário. Essa coluna vertebral permitirá que estados interiores como Goiás estejam próximos do mar e dos navios. Ela coloca o litoral aqui”, declarou a presidenta (...). Hoje a Ferrovia Norte-Sul chega a Anápolis, porque está sendo o centro logístico do Brasil e, com certeza, terá um papel decisivo na interiorização do desenvolvimento. (...) O Presidente da VALEC, José Lúcio Machado, comemorou essa conquista para o transporte ferroviário no Brasil: "Completamos agora o projeto original da ferrovia, concebido há 27 anos para ser um indutor de desenvolvimento da região central do Brasil. Hoje, a FNS pode ser considerada como estruturadora do Sistema Ferroviário Nacional, trazendo maior qualidade ao serviço de transporte de carga" (VALEC, 2014a).
} 
malhas do Norte e Nordeste, via interior do país, constituindo uma verdadeira "coluna vertebral" da estrutura ferroviária nacional.

A previsão é de que boa parte das mercadorias transportadas até então pelas rodovias passe a ser feita pela ferrovia, de modo a baratear os custos do frete, aliviar as rodovias próximas à zona de influência da estrada de ferro, dinamizar a economia local e regional, e com isso, melhorar a competitividade do país como um todo. A diversidade de possibilidades de integração entre as ferrovias brasileiras já existentes, e aos portos localizados em vários estados flexibilizará as rotas para o transporte das mercadorias. Segundo a VALEC (2014a),

\begin{abstract}
A construção da Ferrovia Norte-Sul, de forma paulatina, contribuiu para o crescimento de regiões. (...) Após percorrer $1.574 \mathrm{~km}$, atravessando o sul do estado do Maranhão, o eixo central de Tocantins e o norte de Goiás, a ferrovia alcança Anápolis, situada na já desenvolvida região central do estado de Goiás.

A FNS, antes vetor de desenvolvimento, passa a ser a espinha dorsal do Sistema Ferroviário Nacional, proporcionando acesso de produtores a vários portos (Itaqui, Santos e Vitória) e corredores de exportação. Além disso, fomentará a competitividade intramodal, não só entre portos, mas também, entre os operadores logísticos que realizarão o transporte da carga.
\end{abstract}

A competitividade entre modais contribuirá para a diminuição nos custos do transporte de cargas destinadas tanto ao mercado interno quanto externo, e também, na importação de mercadorias. A partir da concorrência entre os operadores ferroviários nacionais, o acesso às ferrovias será democratizado amplamente a todos os interessados que tenham condições de operar no sistema, e com isso, espera-se que a eficiência melhore e o preço do frete diminua. Os dados da VALEC (IBIDEM) indicam que,

(...) nesse contexto, além de realizar atividades operacionais de planejamento, manutenção do trecho e controle de tráfego da via férrea, antecipará a aplicação das premissas do novo modelo de exploração de infraestrutura ferroviária, conhecido como open access, lançado pelo Governo Federal em 2012. Esse modelo permite que a ferrovia seja utilizada por diversos transportadores ferroviários, devidamente autorizados por critérios transparentes, não discriminatórios e isonômicos, cumpridas as condições técnicas e operacionais do negócio.

Em um mercado cada vez mais competitivo, o novo modelo conhecido com open access contribuirá para uma operação mais arrojada dos transportes ferroviários, especialmente aqueles destinados a atender demandas de longos trechos com cargas de alto valor agregado. Para isso, as novas ferrovias quando concluídas formarão três entroncamentos de articulação da rede ferroviária sobre o território. 
Figura 33 - Malha Ferroviária do Brasil e os nós de conexões das redes regionais

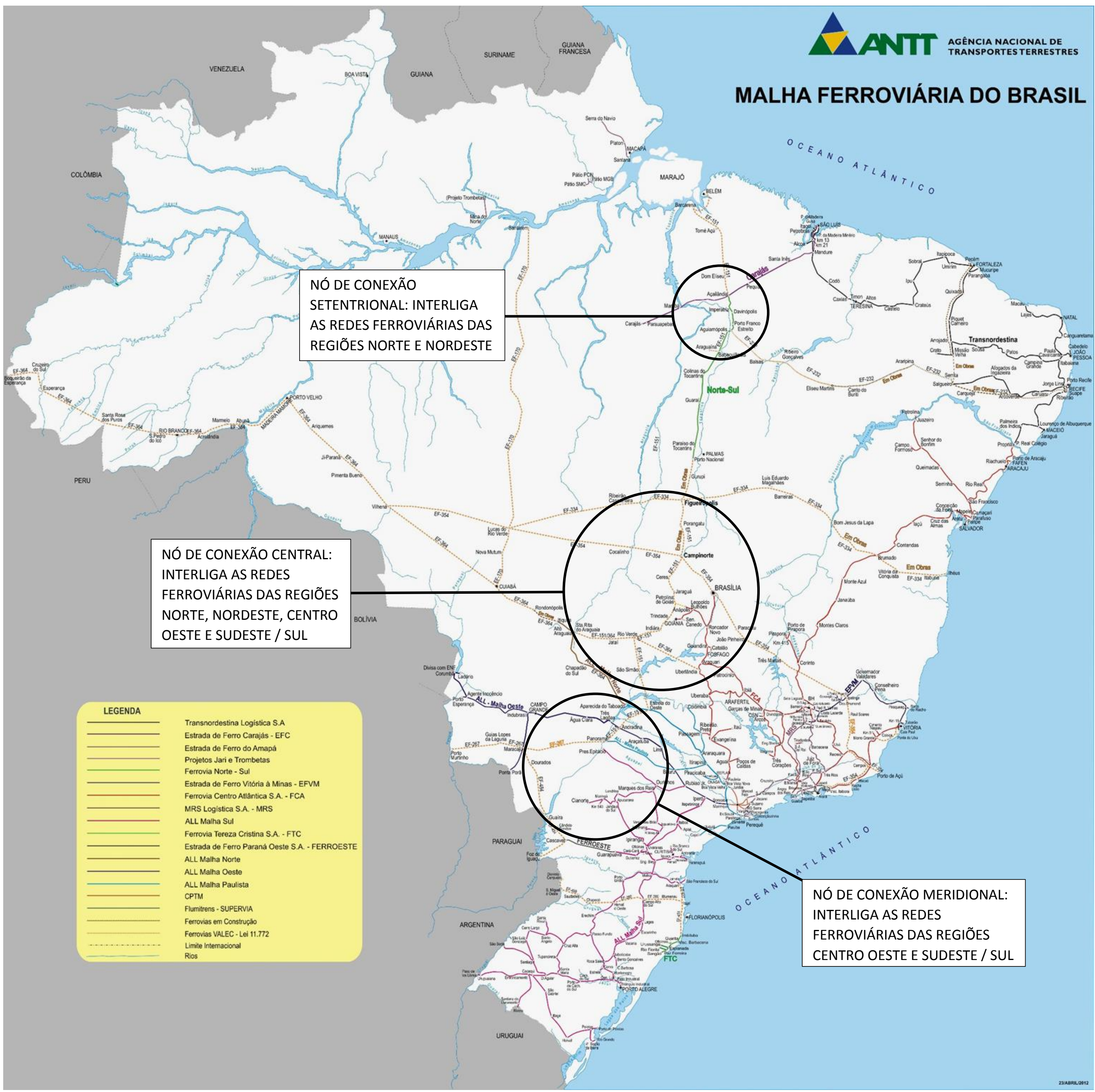

Fonte: Adaptado de ANTT, 2015. 
Os três entroncamentos apresentados na figura 33 aqui foram chamadas de "Nós": Setentrional, Central e Meridional. O Nó Setentrional é formado pela junção da Estrada de Ferro Carajás e a Ferrovia Norte Sul, inclusive sua extensão até Belém. Localiza-se no estado do Maranhão, com grande influência no Pará e em Tocantins. O segundo Nó é o Central, formados pelas ferrovias situadas na divisa de Tocantins com Goiás, as ferrovias presentes no Triângulo Mineiro, em Goiás, Mato Grosso e Mato Grosso do Sul. O terceiro Nó é o Meridional, ligando as ferrovias dos Estado de São Paulo com o Paraná e o Mato Grosso do Sul. Os três nós formam uma "espinha dorsal ferroviária", articulando toda a integração logística nacional, sendo que o nó central, situado em Goiás é o principal, dado ao seu posicionamento e zonas de influência.

A conexão da Ferrovia Centro Atlântica - FCA - com a Ferrovia Norte Sul - FNS -, na cidade de Anápolis, marca o nó central. Junta-se ainda a ligação da Ferrovia de Integração Oeste Leste - FIOL - que liga o litoral baiano até a Ferrovia Norte Sul, na altura da cidade tocantinense de Figueirópolis, e a Ferrovia de Integração do Centro Oeste - FICO -, que quando pronta ligará os Estado do Acre, Rondônia, Amazonas, Pará e Mato Grosso, à ferrovia Norte Sul, na cidade goiana de Campinorte. Embora boa parte das ferrovias ainda estejam em construção, há vários trechos concluídos e em operações. Com relação à Ferrovia Norte Sul, o início da operação do trecho recém inaugurado será imediato em Gurupi - TO e alcançou Anápolis no final de 2014. Conforme os dados da VALEC (2014a),

\begin{abstract}
Inicialmente, será transportado minério de ferro do pátio de Gurupi com destino ao Porto de São Luís/MA. A VALEC venderá a capacidade para a operadora logística VLI, que, por sua vez, mediante o pagamento do frete, fará o transporte da carga da Viena Mineração. (...) O pátio de Anápolis proporcionará o embarque de farelo de soja ainda da safra de 2014 para o porto de Itaqui/MA. Para a safra de 2015, a FNS e o pátio de Anápolis estarão aptos a transportar para aquele porto a integralidade da produção da Granol (1.000.000 toneladas), oferecendo, assim, uma opção logística competitiva às hoje praticáveis.
\end{abstract}

Os portos de São Luís e Itaqui, ambos no Maranhão, serão beneficiados pelo aumento da quantidade de carga transportada. Os novos empreendimentos que estão sendo instalados nas áreas de influência da ferrovia gerarão grandes fluxos de mercadorias. Desta forma as demandas previstas de transportes de cargas são enormes, principalmente em função da integração ferroviária nacional. Segundo a VALEC (Ibidem),

(...) Com a conclusão das instalações de transbordo - troca de bitola - no Porto Seco do Centro-Oeste, também localizado no pátio de Anápolis, será possível reduzir o tráfego de caminhões pela BR-153, por onde circula a carga proveniente da Zona Franca de Manaus. Esta poderá ser transportada de trem pela FNS, a partir de 
Açailândia ou Imperatriz, ambas no Maranhão, sendo transbordadas em Anápolis e seguindo até o seu destino final na região sudeste do país, também de trem.

Observa-se que com as operações de transbordo em Anápolis haverá uma considerável redução de transportes de mercadorias oriundas da Zona Franca de Manaus feito em rodovias, as quais passaram a serem feitos pelas ferrovias. O transbordo deve ser feito em Anápolis, pois a bitola da ferrovia Norte Sul é larga $(1,60 \mathrm{~m})$, enquanto que a bitola da ferrovia Centro Atlântica é métrica (1,0 m). Por isso, as composições da FNS, são incompatíveis para trafegar na malha da FCA, e vice e versa.

Tais operações ainda beneficiarão as cidades maranhenses de Açailândia e Imperatriz na medida em que elas serviram com ponto de embarque desses produtos. Outra cidade beneficiada será Porto Nacional, no Estado do Tocantins, uma vez que está em fase de construção uma das bases de distribuição de derivados de petróleo da BR Distribuidora, além de empresas com a Raízen e a Norship, reestruturando a distribuição de combustíveis no Brasil Central já a partir de 2015. Cidades como Anápolis aumentaram o seu já importantíssimo papel dentro da estrutura logística nacional, com as operações de transbordo do Porto Seco do Centro-Oeste. A figura 34 mostra a qualidade da construção.

Figura 34 - Túnel da Ferrovia Norte-Sul em Anápolis - GO

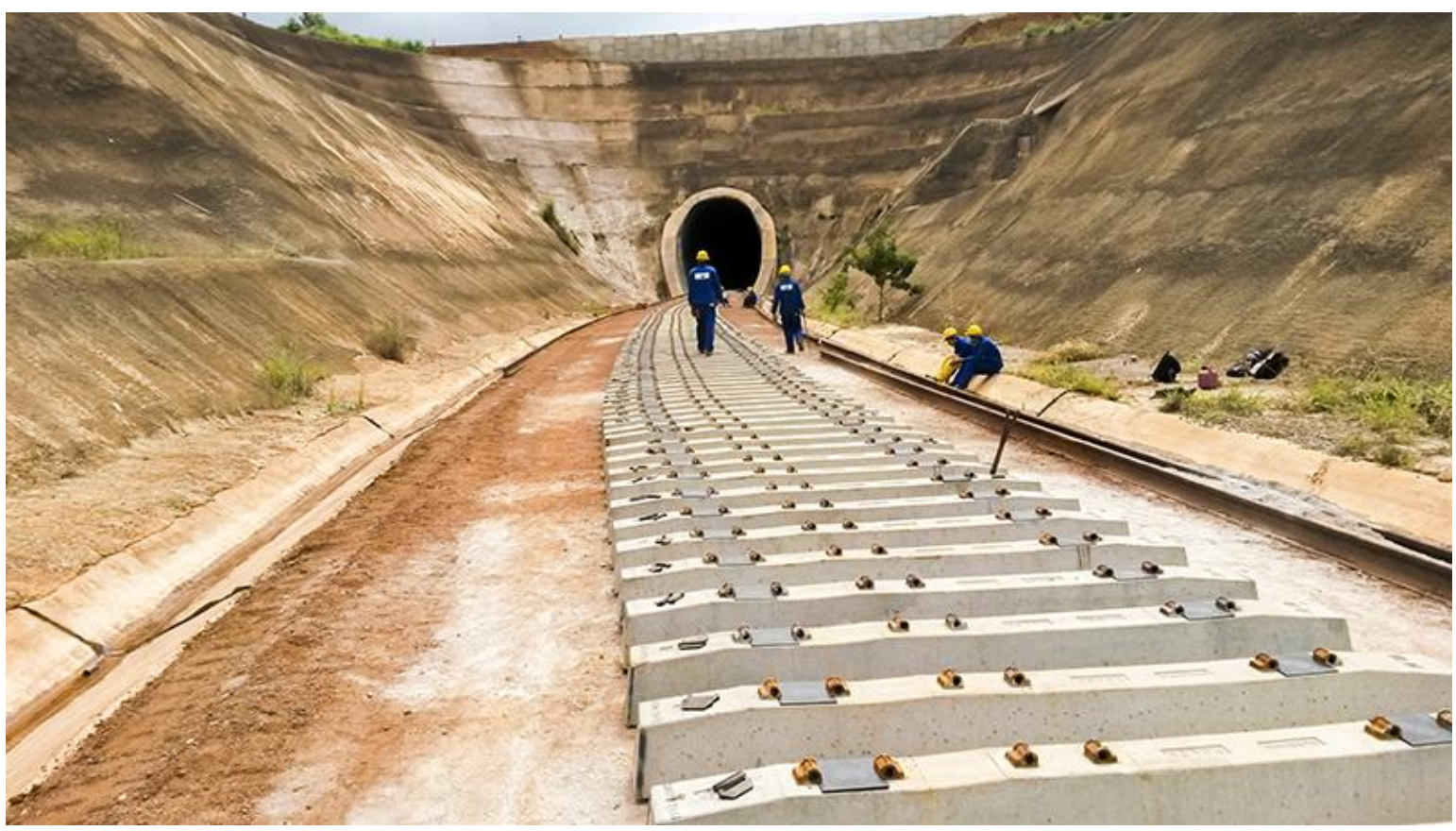

Fonte: VALEC. Disponível em <http://www.valec.gov.br/GaleriaFerroviaNorteSul.php>, acessado em 24 maio 2014 a. 
A figura 34 detalha sobre os materiais empregados e o padrão dos túneis da ferrovia Norte-Sul, no trecho em construção na cidade de Anápolis-GO. A infraestrutura conta com a melhor tecnologia em ferrovias do mundo, a qual utiliza dormentes de concreto com altíssima resistência e durabilidade. Observe que o padrão de dormente possibilita o uso de bitolas mistas, seja de 1,60 ou de 1,00 m, embora inicialmente utilize apenas a bitola mais larga. Isso é possível devido aos dois pontos de fixação de trilhos existentes no lado esquerdo do dormente.

Desde modo ela está preparada para receber as mais modernas composições em operação no país. Ou seja, no quesito qualidade a ferrovia não deixou a desejar a nenhuma outra do país. Assim sendo, Goiás está bem conectado com o país e o mundo. Outras cidades que têm grande importância em Goiás serão Porangatu, Uruaçu, Goiânia, Santa Helena e São Simão, uma vez que terão pátios da ferrovia em seus municípios. A ferrovia ainda prossegue rumo ao Sul do país. Segundo a VALEC (Ibidem),

\footnotetext{
Além da operação do trecho mencionado, a VALEC prossegue na construção de mais $682 \mathrm{~km}$ até Estrela D’Oeste/SP, atualmente com execução física de $60 \%$ e previsão de conclusão para 2015. Paralelamente, a VALEC está na fase final do estudo de viabilidade técnica, econômica e ambiental de trecho compreendido entre Panorama/SP e Rio Grande/RS, que interligará com a Ferrovia do Frango, em Santa Catarina, e, também, alcançará os portos de Paranaguá, no Paraná, e o de São Francisco, em Santa Catarina.

Por fim, o segmento de Açailândia/MA a Barcarena/PA, que foi incluído no PIL Programa de Investimentos em Logística, do Governo Federal, a ser objeto de futura concessão nos moldes do novo modelo de exploração de infraestrutura ferroviária, confirmará a Ferrovia Norte-Sul como a ferrovia estruturadora do Sistema Ferroviário Nacional.
}

Com isso, o papel da Norte-Sul é integrar as ferrovias de todas as regiões brasileiras. Quando estiver totalmente pronta, ocorrerá uma nova etapa de interiorização de investimentos seguida de migrações para as áreas adjacentes às novas ferrovias. Entretanto, será estabelecida em novas bases, fundamentando-se na modernização e na inovação da apropriação capitalista do território, e não somente integrando. Além da modernização da economia e do reordenamento territorial, as novas ferrovias aproximaram o interior do país de uma forma muito mais intensa ao litoral e ao mercado internacional.

\subsection{O ENTRONCAMENTO: CONTRIBUIÇÃO LOGÍSTICA.}

Os avanços das frentes pioneiras, caracterizada principalmente pela intensificada incorporação do espaço pelo capital proporcionou o "despertar" da área em estudo, que como 
já foi discutido, estava vivendo um demorado processo de estagnação devido ao fim do ciclo do ouro. A partir do ciclo do café tudo mudou, estabelecendo um processo de paulatino avanço na incorporação do território.

As principais consequências do avanço da fronteira foram: o aumento da concentração populacional, a apropriação das terras "livres" pelo capital, o aumento do número de cidades, a devastação do cerrado para a implantação da agricultura intensiva e o crescimento econômico da área em estudo (BARREIRA, 2002). Consequentemente houve também o aumento do número de vias de acesso, obedecendo aos planos de integração nacional que previam o incremento da apropriação territorial para atender a necessidade de crescimento econômico e o aumento da segurança e poder, dentro da geoestratégia nacional.

Neste processo, observa-se uma concentração maior de vias de acesso, tanto rodovias quanto as ferrovias, vinculados ao atendimento das demandas de Brasília. Grande parte delas começam na própria capital e seguem em direção à todas as regiões do Brasil, seja o Nordeste, o Sudeste, o Sul, outras unidades federativas do Centro Oeste, e inclusive, a Região Norte. Ou seja, ao observar-se o posicionamento de cada rodovia e da ferrovia a partir das cidades e estados que por elas são ligados, fica mais fácil entender a logística de transportes da nação.

Não foi por acaso que Brasília, à luz da geopolítica de poder nacional, está situada no centro do país e passa a distribuir as principais vias de acesso em todas as direções do território nacional. Tais vias favorecem o crescimento econômico e a incorporação das áreas de fronteira da nação. Desta forma, Brasília é a grande centralidade na rede logística brasileira, e por causa dela, induz a localização do entrocamento logístico ferroviário nacional em Goiás.

Do ponto de vista econômico, o avanço da fronteira além de permitir o crescimento dos investimentos, possibilitou também a implementação de enorme infraestrutura na área. Várias rodovias foram construídas, muitas cidades foram criadas, e uma maior quantidade de pessoas passou a morar na região. Ao referir se ao avanço da fronteira econômica na área, Gomes et al (2004: 99) destaca que

A partir de 1950, quando Goiânia se consolidou de vez como o mais importante centro urbano de Goiás - Tocantins, e, por isso mesmo, um chamarisco para as populações migrantes, o número de cidades novas não mais pararia de crescer, mudando de uma vez por todas a fisionomia urbana do território goiano tocantinense, mais na parte sul (Goiás) que na parte norte (Tocantins). 
Figura 35 - Fatores de Urbanização vinculados às Ferrovias e Rodovias

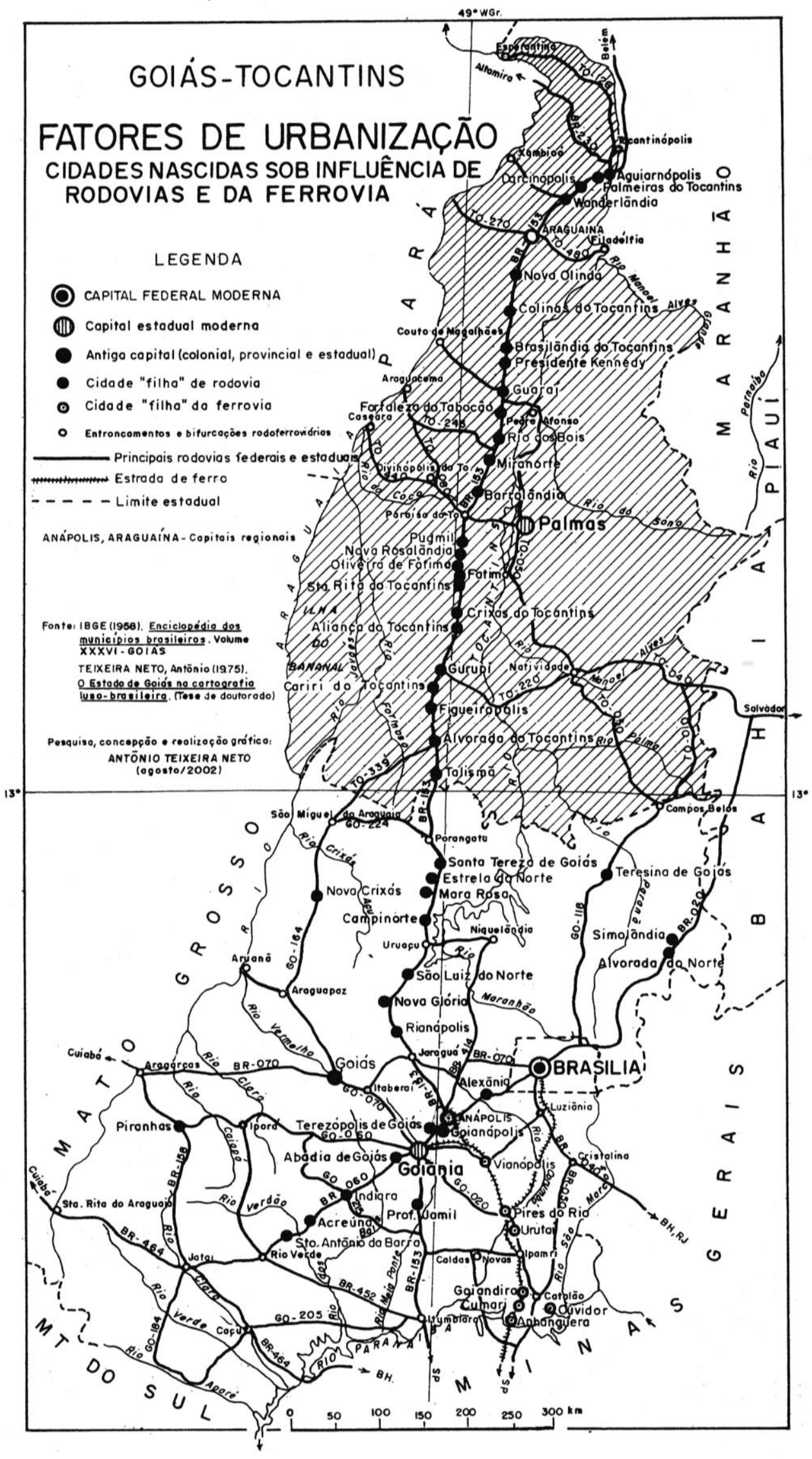

Fonte: Gomes, 2004, p. 76. 
A figura 35 indica as cidades "filhas" das vias de acesso goianas, sejam ferrovias e rodovias. Como na época, o Tocantins ainda fazia parte de Goiás, aqui é apresentado com uma única unidade da federação.

Pelas razões já invocadas, o processo de urbanização no Tocantins só iria ganhar ritmo mais acelerado com a chegada da Belém - Brasília. Então, naquele ano (1950) o censo registrava a existência de 77 cidades, das quais 14 localizavam-se no Tocantins e 63 em Goiás. (...)

Na década de 1960 ocorreu a explosão urbana em Goiás - Tocantins, quando 102 novas cidades surgiram, elevando o total para 179. Já em 1970, como reflexo dessa geopolítica, o número de cidades goiano-tocantinenses cresce mais $23 \%$, chegando a 221 , das quais $171 \mathrm{em}$ Goiás, o que significou um incremento de $16 \%$, e 50 no Tocantins representando um aumento de $56 \%$. Visualiza-se que o espaço de novas oportunidades a partir de então não era mais o "velho" sul goiano, mas sim o "novo" norte tocantinense. De acordo com Gomes et al (2004: 99),

\begin{abstract}
A partir de 1989, após a separação sem dor dos estados irmãos, a dinâmica urbana adquire de novo um ritmo, desta vez mais acelerado. O Tocantins que nasce com 62 municípios, já contava, por ocasião do recenseamento geral de 1991, com mais outros 17, totalizando então 79. (...) Em Goiás, 47 novos municípios foram acrescentados aos 173 já existentes em 1980, totalizando 220. O recenseamento de 2000 registrava em Goiás 242 municípios instalados e mais quatro novos criados, totalizando 246. No Tocantins, esse total chega a 139, o que representa um incremento de $75 \%$ no período $1991-2000$.
\end{abstract}

A força da circulação via redes logísticas fez com que várias cidades fossem criadas, materializando o avanço das Frentes Pioneiras, e o reordenamento geopolítico do território. Os dados estatísticos comprovam o crescimento demográfico, municipal e urbano da área em estudo, e também um considerável processo de fragmentação territorial resultante da criação dos novos municípios. Desta forma, é de se esperar que o número de vias de acesso aumentasse, especialmente por causa destas três cidades: Goiânia, Brasília e Palmas.

Ao tentar-se construir uma breve síntese das influências do avanço das Frentes Pioneiras, observa-se que a fronteira econômica ao passar pela região em estudo estabeleceu e ainda estabelece várias transformações sócio-econômicas-espaciais. Desta forma, contemplase o resultado da expansão das Frentes Pioneiras que começou a partir da região das Estradas de Ferro Mogiana e Goiás, passando pela integração rodoviária e aquaviária, e segue, doravante com as contribuições da Ferrovia Norte-Sul. A figura 36 mostra o conjunto das ferrovias da VALEC, em seus diversos estágios de construção. 
Figura 36 - Ferrovias VALEC no Brasil em 2013.

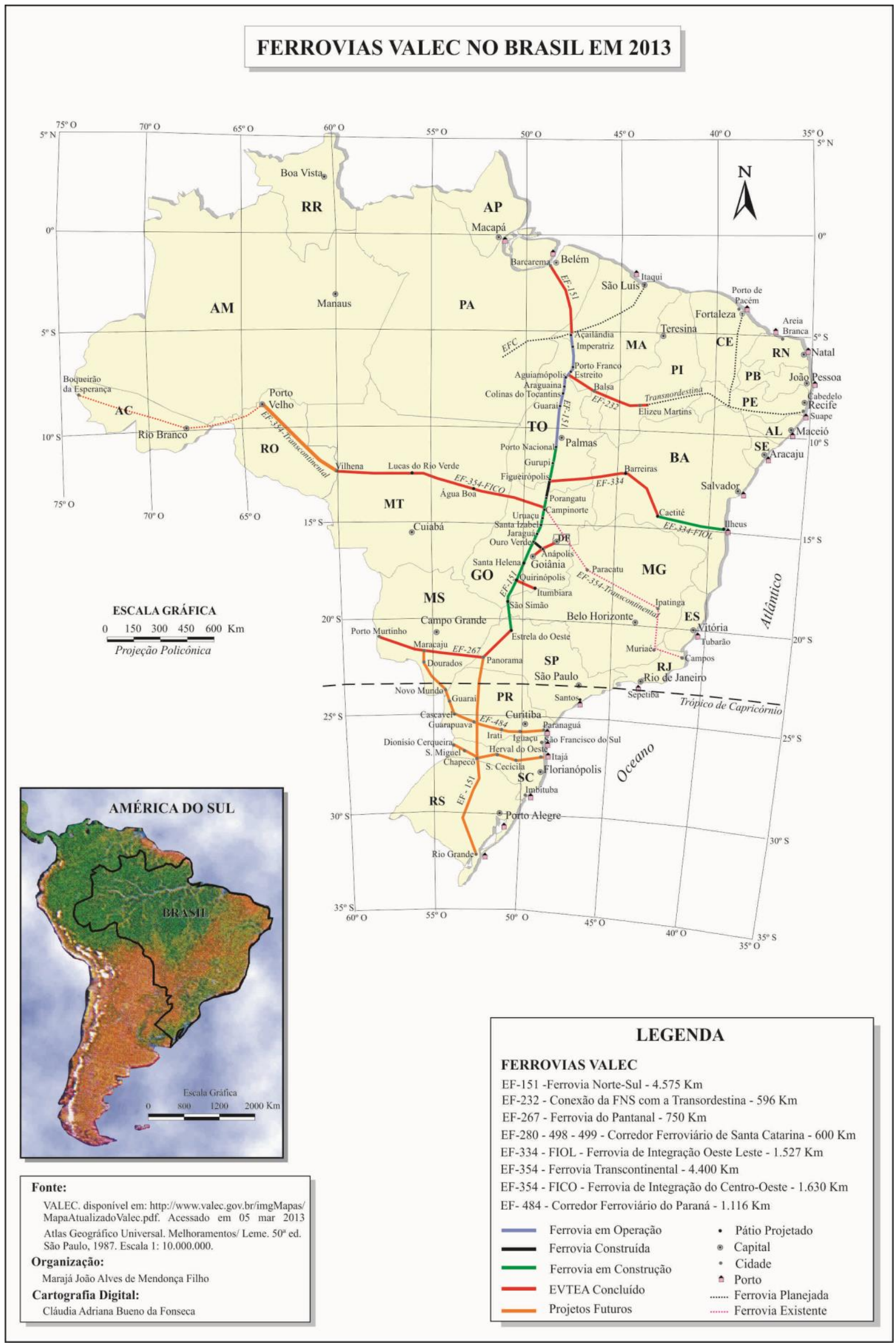


Através da figura 36 evidencia-se a quantidade de ferrovias que estão prontas, em fase de construção, planejadas e em planejamento. Tal situação certamente motivará a instalação de um maior número de empresas e outros empreendimentos econômicos, resultando em crescimento populacional, recebimento de fluxos migratórios, com consequente necessidade de planejamento para atender tais demandas. Considerando apenas a parte concluída da ferrovia entre Palmas - TO e Anápolis - GO, sem dúvida tornou-se um grande corredor de integração da logística ferroviária nacional.

O resultado prático de tudo isso é que de acordo com a estratégia do projeto, já estão sendo implantados nos Estados de Goiás e Tocantins 42 plantas industriais de etanol e 20 usinas de biodiesel, para consolidar o desenvolvimento do corredor Centro - Oeste. A ideia é impulsionar a produção na área do cerrado e promover a geração de empregos nas comunidades do interior do país (VALEC, 2004b).

Os treze Pátios Multimodais que estão em construção em pontos estratégicos ao longo do percurso da Norte-Sul, proporcionarão a articulação entre o sistema fluvial da Bacia Amazônica e o sistema ferroviário nacional. Com isso espera-se reduzir o custo dos transportes, o consumo de combustíveis, os pesados ônus de manutenção do modal rodoviário e os índices de acidentes nas estradas. Portanto, constituir-se-ão em agentes dinamizadores das atividades agrícolas e minerais de toda a área beneficiada, promovendo o surgimento de novas indústrias e o crescimento do comércio (VALEC, 2004b).

Assim, com a conclusão da ferrovia Norte - Sul haverá novas alternativas para o escoamento da produção, não apenas via Portos do Sudeste, mas também, pelos Portos do Nordeste. Do ponto de vista econômico, a Norte - Sul, no estado de Goiás, será um grande entroncamento logístico do país em virtude das novas ferrovias em construção. Segundo dados disponíveis no site da VALEC, a Ferrovia Norte - Sul terá como objetivo:

\footnotetext{
A integração ferroviária das regiões brasileiras será o grande agente uniformizador do crescimento autossustentável do país, na medida em que possibilitará a ocupação econômica e social do cerrado brasileiro - com uma área de aproximadamente 1,8 milhões de $\mathrm{km}^{2}$, correspondendo a $21,84 \%$ da área territorial do país, onde vivem $15,51 \%$ da população brasileira - ao oferecer uma logística adequada à concretização do potencial de desenvolvimento dessa região, fortalecendo a infraestrutura de transporte necessária ao escoamento da sua produção agropecuária e agroindustrial (VALEC, 2011).
}

Destaca-se a preocupação governamental em incrementar uma política de transportes que aproprie intensivamente das áreas de cerrado do país com o objetivo de promover o crescimento econômico. Outro aspecto é o esforço de ocupação diferenciada do território a 
partir de uma estratégia econômica de integração das regiões brasileiras via redes férreas. Veja os propósitos citados a seguir:

A articulação de diferentes ramos de negócios proporcionada por sua implantação está contribuindo para o aumento da renda interna e para o aproveitamento e melhor distribuição da riqueza nacional, a geração de divisas e abertura de novas frentes de trabalho, permitindo a diminuição de desequilíbrios econômicos entre regiões (...) (VALEC, 2011).

Todas as ferrovias do grupo VALEC destacam-se pela modernidade técnica e tecnológica, pois seguem padrões internacionais de construção e operação, o que resultará em serviços mais rápidos e eficientes com melhores índices de toneladas por quilômetro útil TKU. A ferrovia Norte - Sul contribuirá para a economia brasileira, pois possibilitará a expansão da diversidade e quantidade de riquezas produzidas em sua zona de influência.

Outro importante fator a ser ressaltado é a redução com os custos dos transportes e a diminuição do consumo de combustíveis ao destinar boa parte do transporte de cargas para o modal ferroviário, ao invés de utilizar o modal rodoviário, cujos ônus de manutenção são pesados. Além disso, diminuirá os índices de acidentes nas rodovias. Considerando as ferrovias já existentes e a suas conexões com as novas que estão em construção no estado de Goiás, farão deste um grande entroncamento ferroviário nacional.

Pelas ferrovias goianas serão ligadas as redes férreas das regiões Sul e Sudeste com as ferrovias das regiões Nordeste e Norte, além da ligação com as linhas já existentes nos demais estados do Centro - Oeste. Neste sentido, dos trechos já concluídos, há uma parte da ferrovia Norte-Sul que liga as cidades maranhenses de Estreito e Açailândia que está em operação comercial desde 1996. O volume de carga transportado pelos trilhos já concluídos tem alcançado anualmente um aumento expressivo, atingindo o patamar de 8,9 milhões de toneladas desde o início da operação comercial, até julho de 2012.

Segundo dados da Agência Nacional de Transportes Terrestres - ANTT, os principais produtos transportados são soja e farelo, areia e minério de ferro. A extensão construída da Ferrovia Norte - Sul até setembro de 2011 chegou a 720 quilômetros (ANTT, 2012). Neste sentido, o projeto da Ferrovia Norte - Sul segue atraindo novos investimentos em sua zona de atuação.

Ao construir a ferrovia Norte-Sul o estado brasileiro contribui com o crescimento da economia brasileira ao facilitar a logística dos transportes de mercadorias no interior do país, e mais especificamente em Goiás. A VALEC chama a atenção no seu site para a capacidade da ferrovia em atrair grandes "trades" internacionais da produção de grãos. Observe: 
O papel catalisador de oportunidades geradas pelo binômio energia e transportes, pode ser comprovado no Polo Agrícola de Balsas (MA), onde a diretriz da Ferrovia Norte-Sul já está em operação, tem propiciado o crescimento da área plantada e, consequentemente, da produção de grãos, evidenciando a geração de empregos e renda, bem como a atratividade de investimentos privados. Do mesmo modo que o Pátio de Integração Multimodal de Porto Franco (MA), situado no quilômetro 190 da Ferrovia Norte-Sul, abriga as "trades" Bunge, Cargill e Multigrain, empresas que, atraídas pelas oportunidades oferecidas pelo transporte ferroviário, investiram cerca de US\$ 6 milhões em instalações para as operações de carga, transbordo e armazenagem de grãos (VALEC, 2011).

Ao destacar a presença de grandes multinacionais ao longo da ferrovia, evidencia-se o propósito chave do desenvolvimento econômico do país, convertendo as potencialidades naturais em lucros. Mais uma vez evidencia-se que a análise da geopolítica dos transportes é fundamental para o desenvolvimento do país, e particularmente de Goiás. Ao fazer uma releitura da apropriação geopolítica dos territórios dos estados brasileiros, e em nosso caso, da intensificação da apropriação econômica do território goiano a partir da inserção de novas ferrovias, o esforço nacional em prol do crescimento econômico e social torna-se evidente.

A análise estratégica das ferrovias é de fundamental importância não apenas para a defesa e a manutenção do território, mas também, para o desenvolvimento econômico e social da nação. Todo o planejamento territorial dessa ocupação visa à reestruturação dos processos produtivos, de modo a transformar as potencialidades naturais em benefícios econômicos.

Evidencia-se cada vez mais o aumento no número de habitantes em função das migrações de muitos cidadãos de outros estados brasileiros, como Minas Gerais e São Paulo no final do século XIX e início do século XX, Maranhão e Bahia no final do século XX e início do século XXI, em busca dos novos empregos e de melhores condições de vida. Observa-se ainda um processo crescente de instalação de indústrias em Goiás e a expansão de atividades do setor primário, como a produção de carne, grãos e minérios, o que é positivo para o estado.

A previsão de introdução de novos e grandes fluxos de capitais traz consigo boas expectativas quanto às possibilidades de melhoria na estrutura produtiva goiana, caso sejam devidamente destinados e empregados. A figura 37 mostra que o centro da malha ferroviária nacional, existente e em construção, incluindo as planejadas, situa-se em Goiás. 
Figura 37 - O Entroncamento Logístico Ferroviário Nacional e suas articulações logísticas.

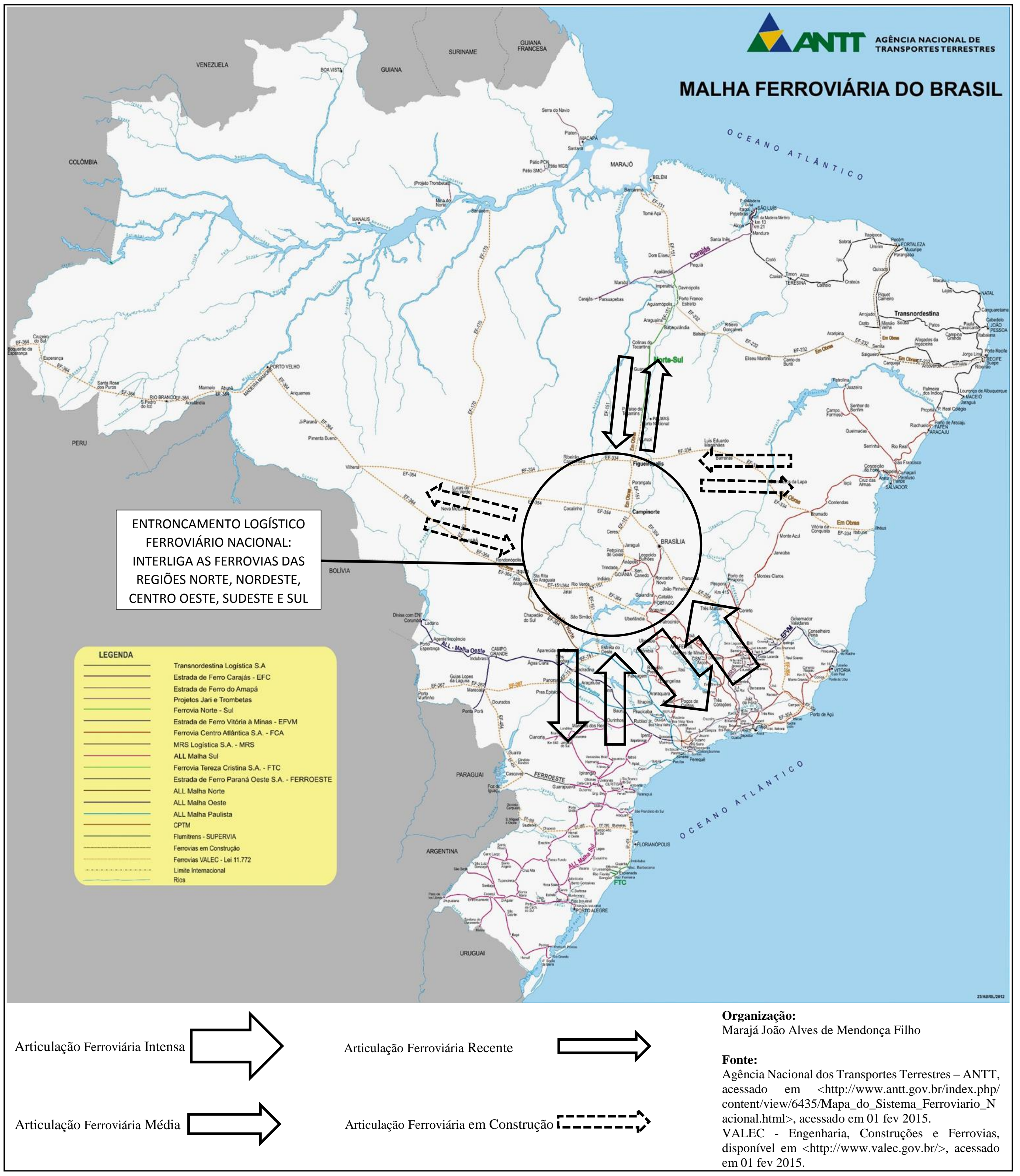


Ao se fazer uma releitura geopolítica da produção do território evidencia-se a importância do correto planejamento estatal para o desenvolvimento da nação brasileira. Portanto, o estado precisa investir em infraestrutura de transportes para aumentar a competitividade econômica brasileira em nível internacional, atraindo investimentos, gerando emprego e renda. Essa maior disponibilidade de recursos financeiros, tanto públicos quanto privados, poderá contribuir na melhoria da qualidade de vida da nação.

No mundo contemporâneo os fatores eficiência e competitividade são condições obrigatórias para atrair investimentos de modo a fortalecer o desenvolvimento nacional. A ferrovia Norte-Sul será de fundamental importância para o aumento da competitividade do Brasil, e mais especificamente, do estado de Goiás diante do cenário internacional. Com infraestrutura moderna, equipamentos mais potentes, velozes e econômicos, aliados a tecnologia de comunicação e rastreamento via satélite, os custos de transportes diminuirão, e com isso, impactarão menos o valor do frete embutido nas mercadorias. O resultado é corte de custos e aumento dos lucros, tornando os produtos brasileiros mais baratos, e com isso, mais competitivos diante do mercado internacional.

A ferrovia Centro - Atlântica foi conectada à malha ferroviária da Norte Sul, de modo que já existe a plena ligação entre as malhas férreas do Norte e Nordeste do Brasil com a as ferrovias do Sudeste e do Centro Oeste. Futuramente, após a inauguração do tramo sul da Norte Sul, que atualmente encontra-se em construção, será possível conectar de forma mais eficiente os estados da região Sul do Brasil à rede ferroviária nacional, privilegiando a circulação como um todo.

Outras ferrovias planejadas, como a Transcontinental, atravessará o Brasil de leste a oeste, desde o litoral carioca, a partir da cidade de Campos, passando pelos estados de Minas Gerais, pelo Distrito Federal, pelos estados de Goiás, Mato Grosso, Rondônia, até chegar ao Acre, na cidade de Boqueirão da Esperança. A Transcontinental integrará as ferrovias brasileiras às ferrovias do Peru, e por elas ligará o litoral do Oceano Atlântico ao litoral do Oceano Pacífico. Inúmeras possibilidades de investimentos surgirão com as novas ferrovias.

A conexão da ferrovia Transoceânica com a Norte - Sul será em Goiás, nas proximidades da cidade de Uruaçu, proporcionando uma enorme vantagem competitiva para o Estado. A estrada de ferro 334, que parte de Ilhéus rumo ao estado do Tocantins é outra importante via que será conectada na ferrovia Norte - Sul, nas proximidades da fronteira norte de Goiás, na altura da cidade de Figueirópolis - TO. Desta forma, muitas mercadorias que precisarem ir ou vir de Ilhéus para outras partes do Brasil necessariamente acabarão passando 
pelo trecho goiano da Norte - Sul, o que também potencializará o desenvolvimento do Estado de Goiás.

Quando as novas ferrovias estiverem prontas, Goiás passará a contar com um modelo de transporte extremamente competitivo em suas principais cidades e nos principais distritos, tanto agroindustriais como minero industriais. Destacam-se as cidades e distritos de Anápolis (onde há um Porto Seco), Catalão, Jataí, Rio Verde, Goiânia, Uruaçu, Campinorte, Porangatu, Santa Helena, Itumbiara e São Simão (onde há um porto fluvial). Desta forma haverá uma grande integração multimodal das ferrovias com os transportes rodoviário, fluvial e aeroviário. Consideráveis oportunidades de desenvolvimento estão surgindo, o que certamente contribuirá para colocar o Estado de Goiás entre os mais desenvolvidos do país.

Com a expansão da malha ferroviária, a partir da construção da ferrovia Norte-Sul, há a expectativa de um considerável crescimento econômico em Goiás. Além de diminuir os custos da produção, a ferrovia terá condições de contribuir para a integração do mercado interno no Brasil, o que favorecerá também o fortalecimento da economia a partir de diversas possibilidades de negócios que serão feitos.

Tais aspectos motivarão a busca de uma melhor qualificação profissional e da luta pelas melhores vagas no mercado. Com mais recursos públicos advindos dos impostos, maior qualificação e educação, teremos cidadãos mais preparados, instruídos, e em condições de exercer a cidadania. Portanto, atrairá investimentos e contribuirá para o desenvolvimento goiano.

Como o Estado de Goiás se insere no contexto de uma economia cada vez mais globalizada, é de fundamental importância investir na modernização de toda a estrutura produtiva, seja no sistema energético, nos sistemas de gestão e principalmente, na logística dos transportes. Tais aspectos contribuem para que os produtos goianos tenham custos de transportes cada vez mais baratos e sejam, portanto, mais competitivos em âmbito nacional e internacional.

O papel do Estado de Goiás na geopolítica nacional é ser o heartland brasileiro, devido ao seu posicionamento central e o seu contato direto com estados de quatro das cinco regiões brasileiras, excetuando apenas a Sul. Tal papel completa-se com a aliança territorial do Tocantins e o Distrito Federal, consolidando a área do Brasil Central. Todavia, para que o papel articulador de Goiás funcione adequadamente, é preciso que exista uma rede logística direcionada a todas as regiões do país, valendo-se de todos os modais possíveis, como hidrovias, ferrovias, rodovias, aerovias e dutovias. 
A construção da rede ferroviária goiana e a sua conexão com as demais redes férreas brasileiras iniciou o processo de dinamização econômica do estado, constituindo a vanguarda logística deste. Mais tarde Goiás passou a contar com outros modais, como as aerovias, rodovias, hidrovias, e por último, a estrutura dutoviária. Antes das ferrovias, predominavam em Goiás as antigas estradas reais e vicinais, em leito natural.

O Estado de Goiás recebe a partir do final do século XIX a tarefa de produzir alimentos para suprir o Estado de São Paulo, que na época estava focado na monocultura do café, e graças à presença da estrada de ferro isso foi possível. É notório que os trilhos não permitiram somente a ida de gêneros alimentícios para São Paulo, mas também, a vinda de várias pessoas que migraram para Goiás. O resultado foi a chegada de máquinas modernas, a introdução de técnicas e tecnologias mais avançadas.

Ao relacionar as redes logísticas de transporte, enfatizando as ferrovias, e a geopolítica mundial para a compreensão das interações existentes entre o processo de modernização competitiva da economia atual e o modelo ferroviário brasileiro. Dentro da análise geopolítica, fatores como forma, distância, posicionamento, acessibilidade, maritimidade, continentalidade e recursos naturais, interagem via redes logísticas de transportes para o funcionamento da economia. Dentro do cenário brasileiro do final do século XIX, século XX e início do século XXI, as ferrovias exerceram um papel crucial no fluxo de mercadorias e pessoas, sobretudo pela grande capacidade de carga e o menor custo.

Aplicando os mesmos princípios dentro do Brasil, é possível compreender como as características do território goiano contribuíram, dentro da geopolítica nacional, para a construção das ferrovias em Goiás e seus consequentes benefícios econômicos. Como já comentado no capítulo anterior, a chegada das linhas férreas ocorreu pela parte sudeste de Goiás, adentrando o território a partir de 1913, atingindo a cidade de Ipameri no mesmo ano. Em 1930 a ferrovia alcançou a cidade de Anápolis e apenas em 1952 a capital Goiânia. Os novos fluxos de capitais fortaleceram o comércio goiano e a migração de pessoas de outras partes do país e inclusive, de outros países, que passaram a residir nas cidades localizadas ao longo das estradas de ferro (GOMES, 2004).

A partir da construção de Brasília, ocorrida entre os anos de 1957 e 1960, houve a instalação de várias rodovias que passaram a integrar a nova capital federal com todas as demais partes do país. Consequentemente ocorreu a integração de todo o território nacional a partir dessas novas rodovias, as quais aumentaram em número e tamanho com o passar dos 
anos. Desde então, o resultado foi a paulatina decadência das ferrovias tendo em vista a competição com o modelo de transporte rodoviário.

Obviamente o custo de transporte aumentou consideravelmente, pois o valor do frete em rodovias é mais caro que em ferrovias. Isso se explica pelo fato de que enquanto uma carreta rodoviária geralmente leva em média 35 toneladas de carga por veículo, as composições ferroviárias, por outro lado, conseguem transportar em média 40 vagões com até 150 toneladas em cada um deles. Soma-se a isso a pouca diferença financeira em relação aos custos de combustível e manutenção, e ainda, o fato das ferrovias terem maior durabilidade e não sofrerem com os tradicionais congestionamentos no trânsito, conferindo-lhe economia, agilidade e segurança. De uma forma geral, o custo do transporte ferroviário de Goiás para São Paulo representa em média apenas $40 \%$ do rodoviário, ou seja, menos da metade (ESTEVÃO, 2004).

Mesmo deixando de ser o modelo prioritário de transportes no Brasil a partir dos anos 1960, as ferrovias não deixaram de ser empregadas, mas, passaram a trabalhar com outros tipos de cargas, geralmente com maior valor agregado, como minérios e grãos. Por outro lado, o transporte de passageiros em ferrovias foi praticamente abandonado e substituído pelo transporte em ônibus rodoviários. Com a construção dos oleodutos a partir dos anos 1990, houve também a substituição do transporte de grande parte dos combustíveis que até então era feita prioritariamente em trens, diminuindo a importância das ferrovias para este fim. Em Goiás, a substituição do transporte de passageiros pelo transporte de cargas provocou o abandono da maioria das estações de embarque situadas nas cidades por onde a ferrovia passa.

O crescente fortalecimento da econômica brasileira, vivido nos últimos anos, gerou a necessidade de elaborar políticas públicas que visassem a criação de condições de infraestrutura para atender tal demanda, evitando a estagnação ao atingir o limite da capacidade já instalada. Dentre as várias estratégias, destaca-se a ideia de conectar as ferrovias da região Sul, Sudeste e Centro-Oeste, com as ferrovias das regiões Norte e Nordeste, afim de diminuir os custos com os transportes no Brasil e assim, fortalecer a economia.

Para isso foi projetada a ferrovia Norte-Sul, a qual atravessará todo o território goiano, além de outros estados brasileiros. Além de facilitar a logística de transportes no país, a ferrovia contribuirá na modernização da economia dos estados em que passa. Diferentemente da ferrovia Mogiana, que foi construída em um contexto de limitada integração nacional por causa da inexistência de rodovias pavimentadas no interior do país no início do século $\mathrm{XX}$, a 
ferrovia Norte-Sul, foi construída no contexto de uma integração nacional praticamente consolidada, devido a quantidade das rodovias instaladas.

Entretanto, ela ainda é limitada por causa da falta de transportes mais eficientes e adequados para os produtos com baixo valor agregado e que necessitam de deslocamentos em grandes volumes, como minérios e commodities agrícolas. Isso restringe os tipos de produtos que podem ser produzidos no interior do país, dificultando o seu crescimento e desenvolvimento econômico. Portanto, a ferrovia Norte-Sul é uma resposta a tais necessidades, e por isso ela possibilitará novas transformações no território brasileiro como o incremento no volume e na diversificação da produção. Desta forma, contribuirá sobretudo para o aperfeiçoamento da integração econômica nacional.

Ressalta-se que a origem de boa parte das novas demandas geradas nas fronteiras agrícolas brasileiras ocorre em nível internacional e é transportada pelas ferrovias até os portos do litoral, destinando-as a exportação. Obviamente a rede férrea serve também para a importação de mercadorias. Portanto, insere-se na grande lógica econômica internacional na qual a econômica brasileira está vinculada. Desta forma, a geopolítica dos transportes no país tem relações com a ótica geopolítica internacional, especialmente no aspecto econômico

Deve-se atentar para o determinismo geográfico face às intervenções humanas, quando se considera a configuração dos territórios e dos mares como fontes do poder mundial, principalmente à luz da logística da rede dos transportes que permitem a eficiente circulação dos recursos. Neste sentido, Silva discutindo sobre espaço e poder, afirma que:

\begin{abstract}
O espaço que a Geopolítica interessa é o espaço político em toda a sua plenitude: caracterizado por uma extensão, uma forma e uma contextura bem definidas; possuindo um valor que se pode estimar, embora não se possa medir; abrangendo uma base física mais ou menos compartimentada em regiões e sub-regiões naturais distintas, englobando tanto as zonas já vivificadas pela ocupação efetiva de aglomerações humanas - o ecúmeno - como zonas mortas ou passivas à espera de uma valorização real; compreendendo um núcleo central, denso de população, bem integrado por uma trama complexa de comunicações e caracterizado por um alto índice de produção, núcleos secundários ou marginais e o simples domínio mais ou menos permeado que a todos circunda; os limites do território, as fronteiras políticas - frentes de contato, e principalmente as fronteiras de civilização no sentido de Bowman - "as Janelas abertas aos empreendedores sobre um mundo ainda desaproveitado" (Siegfried); zonas vitais cuja perda se traduzirá na anulação do poder de recuperação do Estado, áreas críticas de produção e de circulação, zonas - problemas à espera de soluções $(1981$, p. 34).
\end{abstract}

$\mathrm{Na}$ citação de Silva evidencia-se o conceito de redes, a partir da conexão das centralidades, os "nós" às demais áreas de influência e ou interesses econômicos, através dos arcos, rodovias, hidrovias e no caso em estudo, das ferrovias. A partir do meio natural, o 
Estado pode elaborar suas políticas de intervenção espacial, direcionando-as à solução dos seus problemas e buscando o "bem estar da nação". A valorização do território ocorrerá de acordo com as metas estabelecidas pelo Estado, o qual direcionará decisivamente os fluxos de circulação de pessoas, mercadorias, serviços e investimentos financeiros.

$\mathrm{Na}$ Geopolítica, segundo a opinião de Becker (1995) é ao espaço que se atribui o poder, particularmente ao meio físico. O desejo de modificar o mapa político mundial para o controle de recursos e posições se manifesta desde a Antiguidade, gerando a tradição do "direito natural", ou seja, entendendo se as condições naturais como vantagens que preveem a ordem política mundial. Desta forma, o ideário da expansão territorial recebeu um impulso diferencial da evolução ocorrida nas tecnologias de transportes. Isso fez com que o raciocínio de poder deixasse de contemplar a visão eurocêntrica, ocasionando o entendimento do não monopólio de poder para uma só área.

Com relação ao Estado de Goiás, faz se necessário retomar a análise da situação desta unidade federativa que está no seio do Brasil Central. Boa parte dos deslocamentos ferroviários feitos em terras goianas vem de outros estados, e outra parte diz respeito ao recebimento de mercadorias para o consumo goiano. Entretanto, Goiás é a origem de um dos maiores volumes de farelo de soja do país, os quais seguem destino rumo os portos do Sudeste, rumo à exportação. O quadro 3 mostra a quantidade de farelo transportada por estações no Estado de Goiás.

\section{QUADRO 2 Transporte ferroviário de farelo de soja - Estações de origem por UF (2012)}

\begin{tabular}{|c|c|c|c|}
\hline UF Origem & Estação Origem & TU & TKU \\
\hline \multirow{2}{*}{ Go } & General Curado & 272.022 & 475.766 .478 \\
\hline GO Total & Jardim Ingá & 18.330 & 32.297 .460 \\
\hline \multirow{2}{*}{ MG } & - & 290.352 & 508.063 .938 \\
\hline & Araguari & 60.839 & 85.965 .507 \\
\hline MG Total & Brejo Alegre & 535.027 & 675.101 .678 \\
\hline MS & Uberlândia & 58.011 & 81.417 .986 \\
\hline MS Total & - & 653.877 & 842.485 .171 \\
\hline MT & T. Olacyr F. Morais & 753.779 & 991.473 .804 \\
\hline MT Total & - & 753.779 & 991.473 .804 \\
\hline
\end{tabular}

Fonte: CNT (2013, p. 51) 
Percebe-se que Goiás apresentou o quarto maior volume de farelo de soja transportado em ferrovias do país, com um total de 508.063.938 TKU, ficando atrás apenas de Minas Gerais com 842.485.171 TKU, Mato Grosso do Sul com 991.473.804 e Mato Grosso com 2.172.139.608 TKU. As estações de origem foram a General Curado, responsável pelo embarque de 475.766.478 TKU, e Jardim Ingá que embarcou 32.297.460. As ferrovias além de atenderem a vocação do agronegócio em Goiás, também contribuíram para a modernização econômica dele, uma vez que possibilitou a instalação de diversas indústrias.

Com a expansão das malhas, o aumento na quantidade de indústrias é grande, pois se beneficiam de uma posição geográfica estratégica por situarem-se no interior da cadeia produtiva, principalmente do agronegócio. Tudo isso gera uma grande possibilidade de beneficiamento dos produtos primários, e a agregação deste valor no preço final, quando já processados. Para isso, pode se contar com a produção não apenas de Goiás, mas também dos estados adjacentes. Todos estes fatores colocam o Estado de Goiás em uma condição privilegiada quanto a áreas, novos investimentos em ferrovias, crescimento econômico e modernização. 


\section{A FERROVIA NO DESENVOLVIMENTO BRASILEIRO}

O objetivo deste capítulo foi compreender o papel da rede ferroviária nacional no desenvolvimento territorial do país, ao longo dos séculos XIX, XX e XXI. O foco diz respeito à necessidade de estabelecer estratégias competitivas para uma produção com custos cada vez menores, a partir de um modelo de transportes mais eficientes.

No início do século XXI, observa-se que boa parte do Brasil apresenta ainda uma limitada estrutura ferroviária, concentrada apenas em partes das regiões Sudeste, Nordeste e Sul do Brasil e com presença quase irrisória nas regiões Norte e Centro - Oeste. Isso faz com que o chamado "custo Brasil" seja elevado, pois o valor dos transportes acaba encarecendo os produtos, principalmente diante de um competitivo mercado internacional.

Ressalta-se o fato do nosso modelo de transporte, principalmente após a inauguração de Brasília, ter se tornado predominantemente rodoviário, o qual além de ser caro, ainda conta com uma série de limitações quanto às nossas rodovias, que em muitos casos, quando não estão em estado de conservação precário, possuem elevadas taxas nos pedágios. O resultado é a perda de competitividade em nível internacional e um encarecimento desnecessário dos nossos produtos em nível nacional.

Ou seja, paga-se mais do que seria preciso, o que provoca perda de poder de compra, resultando, em efeito cascata, na limitação das condições de vida da população, inclusive na sua própria capacidade de buscar uma melhor qualificação educacional. Portanto, as ferrovias goianas, embora ainda em tamanho pequeno dentro do contexto da economia global, tem sido uma importante infraestrutura para consolidar o processo de desenvolvimento econômico, e também, para criar condições de vida mais adequadas aos cidadãos de Goiás e do Brasil.

Ressalta se o fato das ferrovias no Brasil serem planejadas de modo a integrar as redes férreas, cujo objetivo é garantir o desenvolvimento do território com a efetiva apropriação econômica. Os consequentes incrementos demográficos no interior do país também têm promovido um desenvolvimento mais harmônico e equilibrado entre as regiões, contribuindo para a distribuição populacional que até então estava concentrada no litoral.

Como já observado anteriormente, ressalta-se que no início do século XX a rede ferroviária brasileira estava concentrada em partes das regiões Sudeste e Sul, onde se encontram os principais "nós", e também no litoral nordestino. Por outro lado, as regiões Centro-Oeste e Norte apresentavam pouca integração logística para atender a demanda dos seus mercados, aliando-se a isso a concorrência das rodovias, e por isso, encontravam-se 
estagnadas economicamente. Com os incrementos nas redes férreas, toda essa situação começa a mudar.

A competitividade, no aspecto logístico, diz respeito à diminuição do valor do frete que incide sobre o preço final das mercadorias, sem contudo, reduzir a margem de lucro dos fabricantes e produtores. Com um melhor excedente sobre o preço de custo, há como ganhar fôlego em momentos de crise financeira, principalmente com a possibilidade de reduzir tais lucros para não perder mercado, e / ou ainda, fazer caixa nos momentos bons e usá-los para atravessar os momentos difíceis. As nações cujas economias dispõe de eficientes redes logísticas estão em vantagem no mercado internacional, o que inclusive define os seus papéis na divisão internacional do trabalho. Sobre este assunto, Furtado explica

O efeito combinado do incremento de produtividade nos transportes - redução dos fretes a longa distância - e da inserção no comércio de um fluxo de novos produtos originários da indústria, deu origem a um complexo sistema de divisão internacional do trabalho, o qual acarretaria importantes modificações na utilização dos recursos em escala mundial (1974, p. 77).

Portanto, a referência econômica torna-se hegemônica, determinando o destino dos povos e a configuração dos seus territórios. O sentido de território aqui empregado é a de Milton Santos. Para Santos "por território entende-se geralmente a extensão apropriada e usada. (...) Num sentido mais restrito, o território é um nome político para o espaço de um país" (2001, p. 19). Assim, conceito de território está intimamente vinculado ao imperativo de poder, seja do Estado enquanto gestor nacional, e também da própria sociedade exercendo suas atividades econômicas de modo a atender sobretudo às demandas da sua própria produção e evolução econômica.

Sobre este aspecto logístico, Santos observa que "A história das técnicas é, realmente, a história da convergência dos momentos e a partir da estrada de ferro esse processo de unificação marcha a galope" (SANTOS, 2002, p. 186). A produção do café, enquanto elemento econômico, foi crucial para a aceleração da dinâmica de transformação territorial, e para isso, contou com a imprescindível estrutura logística ferroviária. O resultado foi a transformação do Brasil no maior produtor mundial de café, com a entrada de consideráveis somas de capitais.

Desde então, o volume de cargas transportadas em ferrovias aumentou. Segundo Santos, "quanto às cargas, o uso das ferrovias foi crescente. De 44.846 toneladas em 1960, os fluxos passaram a 235.105 em 1990, isto é, houve um aumento de 5,2 vezes. Em 1994 eram 256.365 
toneladas" (2001, p. 175). É um fato curioso, pois muitos ramais tidos como economicamente deficitários foram desativados.

De acordo com Santos "esse retrocesso é dado, notadamente, pela desativação de vários ramais da região Sudeste, vinculada em grande parte, às políticas de fomento do sistema rodoviário e aos interesses do negócio petroleiro" (2001, p. 63). Isso caracteriza a ideia de redução de custos para melhorar a eficiência logística, principalmente no aspecto custo.

Dentre as políticas públicas empreendidas no século XX, destaca-se a Marcha para o Oeste, responsável pela ocupação demográfica de partes ainda pouco povoadas do território, de modo a incorporar as fronteiras da nação. É preciso lembrar que no início do século XX o desenvolvimento nacional estava concentrado no litoral brasileiro, em especial no Sudeste e em parte das regiões Nordeste e Sul. Por outro lado, as regiões Centro-Oeste e Norte estavam praticamente abandonadas e estagnadas economicamente (MENDONÇA FILHO, 2005, p. $31)$.

Com o crescente fortalecimento da econômica brasileira, observou-se a necessidade de elaborar políticas públicas que visassem à criação das condições de adequação da infraestrutura para atender tal demanda, evitando o risco de estagnação, caso atinja o limite da capacidade já instalada. Dentre as várias estratégias, destaca-se a necessidade de integrar as ferrovias das regiões Sul, Sudeste e Centro-Oeste com as ferrovias das regiões Norte e Nordeste.

O objetivo é diminuir os custos com o transporte no Brasil, e assim, fortalecer a economia. Para isso foi projetada a ferrovia Norte-Sul, a qual atravessa todo o território goiano e tocantinense, além de outros estados brasileiros, e quando do seu término, estará em todas as regiões do Brasil. Além de facilitar a logística de transportes no país, a ferrovia tem provocado transformações positivas na economia dos estados em que passa.

Embora a ferrovia Norte-Sul seja construída no contexto de uma diferente integração nacional, em relação às ferrovias Mogiana e E. F. Goiás, em função da grande quantidade de rodovias já existentes, percebe-se que ela ainda assim, possibilitará novas mudanças no processo de produção econômica do território. Segundo Gomes,

O sonho de se ter uma autêntica espinha dorsal de ferro - propiciando mais mobilidade espacial e viabilidade econômica ao território goiano-tocantinense - está em vias de ser realizado com a construção da ferrovia Norte-Sul, ainda não se perdeu a esperança de se ver concretizado o antigo projeto da verdadeira Transbrasiliana (2001, p. 81). 
O almejado fruto de todo esse processo é a contribuição para o desenvolvimento econômico da nação, a partir do aprimoramento logístico da estrutura de transportes. Com isso, assegura-se uma melhor competitividade dos produtos nacionais por causa do menor custo do frete, principalmente quando a origem dessas demandas em grande parte ocorre em nível internacional. Por isso, a integração ferroviária interior e litoral responderá pelo deslocamento de boa parte da produção que será destinada à exportação. Neste sentido, Santos observa que:

\footnotetext{
O peso do mercado externo na vida econômica do país acaba por orientar uma boa parcela dos recursos coletivos para a criação de infraestruturas, serviços e formas de organização do trabalho voltados para o comércio exterior, uma atividade ritmada pelo imperativo da competitividade e localizada nos pontos mais aptos para desenvolver essas funções (2001, p. 21).
}

Obviamente a ferrovia servirá também para a importação de mercadorias e, portanto, insere-se na grande lógica econômica internacional da qual o Brasil faz parte. Neste sentido, foram trabalhadas algumas ideias sobre a atual produção do território via relações capitalistas. Dentre elas, a produção capitalista do território deveria visar a distribuição dos bens e das riquezas, na mesma medida em que a economia está crescendo.

Por essa via, segundo a lógica econômica hegemônica, os estados devem se desdobrar para serem instrumentos de diminuição das desigualdades sócio espaciais na medida em que entendem o desenvolvimento das suas sociedades como o resultado final dos investimentos na economia. Assim sendo, é preciso criar um modelo alternativo de desenvolvimento que não veja os investimentos na economia simplesmente na reprodução do capital pelo capital, mas, sobretudo, na geração de benefícios para o contribuinte a fim de diminuir as desigualdades sociais dos cidadãos.

Para isso, a eficiência logística tem sua importância, pois pode manter a condição de competitividade econômica do país ao mesmo tempo em que também poderá favorecer de forma direta a qualidade de vida dos cidadãos em função dos transportes mais seguros e baratos. A fim de compreender melhor essa relação entre transportes e desenvolvimento social, veja o gráfico à seguir, onde compara-se os países que possuem as maiores economias e que são referência nos transportes, em relação aos seus modais de transportes.

Com base no gráfico a seguir, observa-se que o Brasil segue um modelo de transportes cuja proporção entre os modais rodoviário e ferroviário assemelha-se ao de países desenvolvidos como Alemanha, França, Bélgica e Dinamarca, onde o rodoviário predomina 
sobre o ferroviário. Observe os círculos na cor azul. Ressalta-se que o tamanho não expressa um valor absoluto, mas tão somente uma referência de comparação quantitativa.

Gráfico 6 - Distribuição do transporte no Brasil em comparação com outros países.

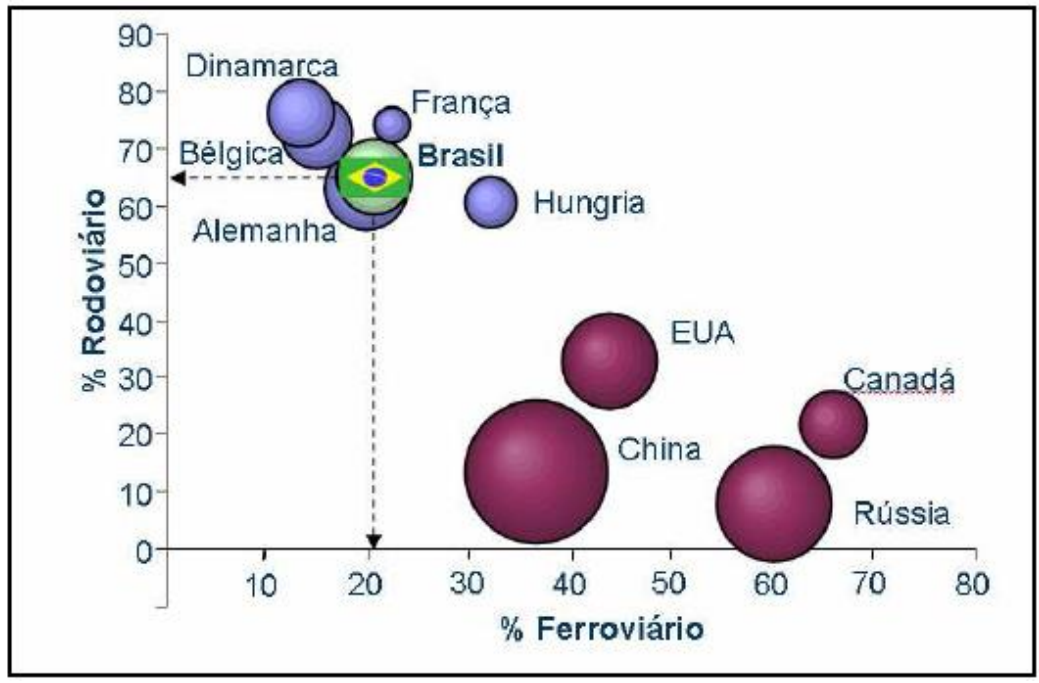

Fonte: COPPEAD / CNT 2001

Entretanto, dada a dimensão continental do território brasileiro, o modelo deveria ser parecido com países de tamanhos geográficos semelhantes, como EUA, Canadá, China e Rússia, onde prevalece o modal ferroviário sobre o rodoviário (círculos na cor vermelha). Isso se deve ao fato de que quanto maior a distância e o volume agregado da carga, menor será o custo, e com isso, mais competitiva será a nação. Sobre este assunto, Resende, Oliveira e Sousa (2009, p. 15) observam que:

Por falta de planejamento, há baixa representatividade das ferrovias em um país com dimensões continentais. Há, no Brasil, uma cultura rodoviarista, ou seja, as questões de inflação e econômicas, que não permitem o dispêndio de tempo no transporte de mercadorias, uma vez que nossa malha e nossa movimentação são muito lentas. Com a estabilização da moeda, as dificuldades econômicas associadas à necessidade de crescimento trouxeram dificuldades no ponto de vista da operação.

Desta forma, é preciso que a nação cresça economicamente, superando seus problemas logísticos, para que tenha recursos suficientes a fim de atender as demandas da sociedade. Para isso, deve-se redimensionar a estrutura de transportes, focando em ferrovias para o deslocamento de cargas, e assim, aliviar as rodovias para outras finalidades, inclusive o movimento de carga de menor volume agregado. Isso proporcionaria ao Brasil, um modelo mais eficiente, como o estadunidense. 
Para melhor entender a diferença, a tabela a seguir compara a estrutura de transportes do Brasil e dos EUA, considerando os principais modais de transporte em relação a três tipos de mercadorias: cargas em geral, produtos agrícolas e o complexo soja. Observe a diferença entre o EUA e o Brasil em todos dos tipos de cargas, onde aquela nação apresenta índices bem superiores de uso do modal ferroviário sobre o rodoviário.

Tabela 2 - Matriz de transporte de cargas em geral e de produtos agrícolas no Brasil (\%)

\begin{tabular}{|c|c|c|c|c|c|c|c|c|}
\hline \multirow{2}{*}{ Modal } & \multirow{2}{*}{$\begin{array}{c}\text { Geipot }^{(1)} \\
1999\end{array}$} & \multicolumn{2}{|c|}{ Caixeta-Filho $^{(2)}$} & \multirow{2}{*}{$\begin{array}{c}\text { Coppead } \\
2003^{(1)} \\
\end{array}$} & \multicolumn{2}{|c|}{ ANUT $-2003^{(3)}$} & \multicolumn{2}{|c|}{ Fleury $-2003^{(1)}$} \\
\hline & & 1995 & Séc. XXI & & Brasil & EUA & Brasil & EUA \\
\hline Rodoviário & 63,9 & 81 & 35 & 65 & 57 & 16 & 61 & 26 \\
\hline Ferroviário & 32,7 & 16 & 56 & 20 & 36 & 23 & 20 & 38 \\
\hline Hidroviário & 0,9 & 3 & 8 & - & 7 & 61 & 13 & 16 \\
\hline
\end{tabular}

Fonte: GEIPOT (2001), CAIXETA-FILHO (2001a), FLEURY (2004), COPPEAD/CNT (2002), ANUT (2004) apud VENCOVSKY (2003, p. 43).

Notas: (1) cargas em geral; (2) para produtos agrícolas; (3) complexo soja; (-) não informado

No Brasil a situação é inversa, pois em todos os tipos de mercadoria o rodoviário supera o ferroviário, e por isso, apresenta menor competitividade. Segundo dados do GEIPOT, para cargas em geral, o modal rodoviário corresponde a 63,9\%, enquanto que o ferroviário apenas $32,7 \%$. A previsão de Caixeta-Filho para o transporte de produtos agrícolas no século XXI é de inversão desta tendência, diminuindo o rodoviário para $35 \%$, aumentando o ferroviário para $56 \%$ e distribuindo $8 \%$ para o hidroviário.

Isso por si só derruba a teoria de que o Brasil seguiu o exemplo rodoviarista americano, sendo que na verdade, o principal modal de transporte de cargas estadunidense são as ferrovias. Essa confusão ocorre pelo fato dos EUA possuir uma robusta estrutura rodoviária. Todavia, o predomínio do transporte de cargas naquele país é feito pelas ferrovias. Com base nos dados do gráfico um, podemos afirmar que o Brasil não seguiu o modelo de transporte americano, apenas incorporou o gosto pelos automóveis sem a devida equivalência quanto às ferrovias.

Isso é comprovando pelos dados da COPPEAD/CNT que estimaram um total de $65 \%$ de cargas em geral para o rodoviário e $20 \%$ para o ferroviário, e não informou nenhum percentual sobre o hidroviário. Já a ANUT comparando o Brasil e os EUA no transporte do "complexo soja", identificou significativa diferença. O Brasil apresentou para os transportes rodoviário, ferroviário e hidroviário os índices de 57\%, 36\% e 7\%, enquanto que os EUA apresentaram $16 \%, 23 \%$ e $61 \%$, respectivamente. Ou seja, exatamente o oposto. 
Para Fleury, tendo como referência o transporte de cargas em geral, os índices também são favoráveis aos EUA, pois apresentam nos transportes rodoviário, ferroviário e hidroviário índices de 26\%, 38\% e 16\% respectivamente. No Brasil esses percentuais mudam para $61 \%$ no rodoviário, $20 \%$ no ferroviário e $13 \%$ no hidroviário. Conclui-se que enquanto no Brasil a preferência é pelo modal mais caro, nos EUA a preferência é pelos modais mais baratos. Com base na tabela 3, observe a diferença entre o Brasil e outros países no quesito rodovias.

Tabela 3 - Densidade de rodovias por países

\begin{tabular}{|c|c|c|c|c|c|c|}
\hline \multirow[t]{2}{*}{ Região } & \multicolumn{2}{|c|}{ Rodovias - total } & \multicolumn{2}{|c|}{ Rodovias pavimentadas } & \multicolumn{2}{|c|}{$\begin{array}{l}\text { Rodovias não } \\
\text { pavimentadas }\end{array}$} \\
\hline & km & $\mathrm{km} / 1000 \mathrm{~km}^{2}$ & km & $\mathrm{km} / 1000 \mathrm{~km}^{2}$ & km & $\mathrm{km} / 1000 \mathrm{~km}^{2}$ \\
\hline Estados Unidos & 6.334 .859 & 657 & 3.737 .567 & 388 & 2.597 .292 & 269 \\
\hline China & 1.402 .698 & 146 & 314.204 & 33 & 1.088 .494 & 113 \\
\hline Japão & 1.161 .894 & 3.075 & 534.471 & 1.414 & 627.423 & 1.661 \\
\hline Índia & 3.319 .644 & 1.009 & 1.517 .077 & 461 & 1.802 .567 & 548 \\
\hline Alemanha & 230.735 & 646 & 230.735 & 646 & 0 & 0 \\
\hline França & 894.000 & 1.634 & 894.000 & 1.634 & 0 & 0 \\
\hline Reino Unido & 371.913 & 1.519 & 371.913 & 1.519 & 0 & 0 \\
\hline Itália & 479.688 & 1.592 & 479.688 & 1.592 & 0 & 0 \\
\hline Rússia & 532.393 & 31 & 358.833 & 21 & 173.560 & 10 \\
\hline Brasil & 1.724 .929 & 202 & 94.871 & 11 & 1.630 .058 & 191 \\
\hline
\end{tabular}

Fonte:- The World Factbook 2003. www.cia.gov, GEIPOT: Anuário Estatístico dos Transportes 2001 (www.geipot.gov.br) apud VENCOVSKY (2003, p. 43).

* rodovias pavimentadas e não pavimentadas

Embora o Brasil tenha uma das maiores malhas rodoviárias do mundo, em tamanhos absolutos, quando se compara o tamanho destas com o território e relaciona-se com as demais nações, a diferença proporcional evidencia-se. Ao se considerar separadamente a parte pavimentada da não pavimentada, a diferença torna-se mais evidente. E são nessas rodovias que grande parte da produção brasileira é transportada.

Portanto, é preciso aumentar em grande quantidade as ferrovias para equilibrar tal diferença ou então acrescentar consideravelmente o número das rodovias pavimentadas, o que resultaria em um modal mais caro que as ferrovias. Conforme observou Ablas (2003, p. 173), "a distância econômica, mais que a física, passou a ser considerada a real medida do mundo globalizado".

Ou seja, você pode produzir em áreas mais distantes do mercado consumidor, desde que consiga entregar os produtos com preços mais baratos do que aqueles que produzem perto deles. Independente da distância, caso consiga ter preços menores, haverá sucesso no empreendimento. Para isso, a eficiência logística deve ser máxima, com o uso dos melhores 
modais, como as ferrovias e hidrovias. Dentro do Brasil, a diferença também existe entre as Unidades da Federação, especialmente quando se compara a infraestrutura com a área de cada Estado.

Evidencia-se a relação entre os estados que possuem maiores densidades rodoviárias e ferroviárias e o desenvolvimento econômico de cada um deles. Ou seja, quanto maior a densidade de rodovias e ferrovias, melhores condições existirão para o desenvolvimento econômico de cada estado. O gráfico 7 mostra a densidade logística.

Gráfico 7 - Densidade de Rodovias e Ferrovias por UF no Brasil

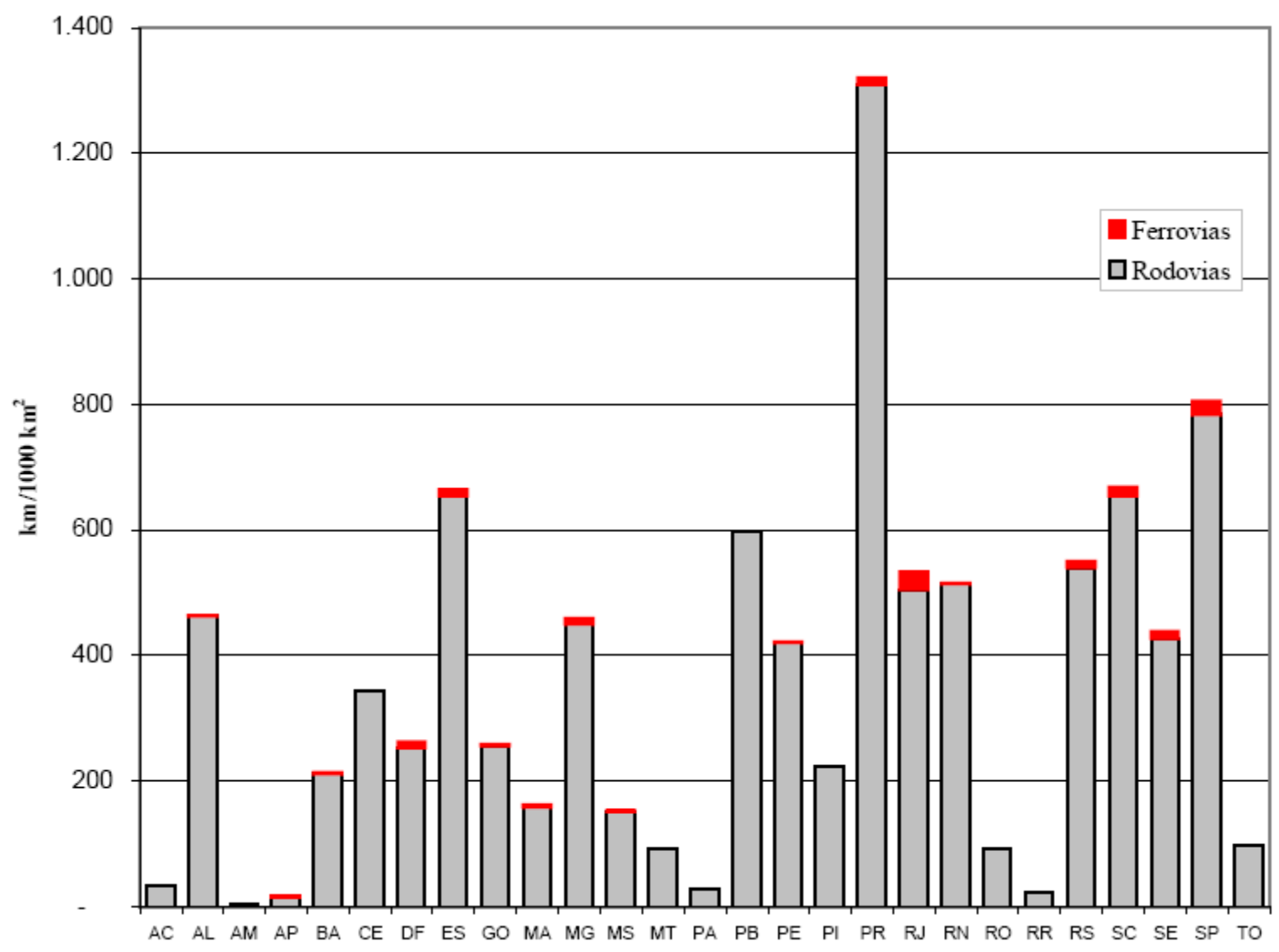

Fonte: GEIPOT - Anuário Estatístico dos Transportes - 1999 (GEIPOT, 1999) apud VENCOVSKY (2003, p. 40)

Outra informação que se destaca é pequena quantidade proporcional de ferrovias em relação às rodovias, inclusive em estados considerados com boa presença delas, como São Paulo, Rio de Janeiro, Minas Gerais, Paraná, Santa Catarina, Rio Grande do Sul, Espírito Santo e Bahia. Mesmo assim, a maior presença de ferrovias por estado coincide com a maior pujança econômica de cada um deles. A tabela 4 mostra a densidade de transporte por grandes regiões. 
Tabela 4 - Densidade de transporte por grandes regiões

\begin{tabular}{ccccccccc}
\hline \multirow{2}{*}{ Região } & \multirow{2}{*}{ Área $\left(\mathbf{k m}^{\mathbf{2}}\right)$} & \multicolumn{3}{c}{ Rodovias $^{\mathbf{l}}$} & \multicolumn{3}{c}{ Ferrovias } \\
\cline { 3 - 8 } & & $\mathbf{k m}$ Total & $\mathbf{0}$ & $\mathbf{k m} / \mathbf{1 0 0 0} \mathbf{k m}^{\mathbf{2}}$ & $\mathbf{k m}$ Total & $\mathbf{0}$ & $\mathbf{~ k m} / \mathbf{1 0 0 0} \mathbf{~ k m}^{\mathbf{2}}$ \\
\hline Brasil & 8.544 .405 & 1.656 .677 & 100 & 194 & 24.567 & 100 & 2,9 \\
Centro-Oeste & 1.612 .057 & 224.953 & 13,6 & 140 & 1.913 & 7,8 & 1,2 \\
Norte & 3.869 .638 & 96.723 & 5,8 & 25 & 451 & 1,8 & 0,1 \\
Nordeste & 1.558 .200 & 396.859 & 23,9 & 255 & 2.968 & 12,1 & 1,9 \\
Sudeste & 927.296 & 479.585 & 28,9 & 517 & 12.437 & 50,6 & 13,4 \\
Sul & 577.214 & 460.557 & 27,8 & 798 & 6.798 & 27,7 & 11,8 \\
\hline
\end{tabular}

Fonte: VENCOVSKY (2003: 41) apud GEIPOT (1999) e concessionárias - (1) Rodovias pavimentas e não pavimentadas - (2)1997 - (3) 1998

Enfim, quanto mais ferrovias, melhor é a condição econômica de cada estado. Em relação às regiões brasileiras, a diferença ainda é grande. A tabela indica de forma clara a diferença no percentual de rodovias e principalmente ferrovias das regiões Sudeste, Nordeste e Sul, em relação às regiões Centro-Oeste e Norte. Mais especificamente no quesito ferrovias, mais de cinquenta por cento delas estão na região Sudeste, chegando a 50,6\% do total do país. No outro extremo, está a região Norte, com menos de $2 \%$ do total nacional, lembrando que geograficamente esta é a maior do Brasil. Portanto, há grandes disparidades entre os estados e entre as regiões, o que justifica a maior força econômica de certas regiões brasileiras em relação às demais. Sobre este assunto Vencovsky observa que

Os pesados subsídios governamentais responsáveis pelo desenvolvimento agrícola nos novos fronts $^{10}$ não levaram em consideração uma questão primordial para qualquer atividade econômica e social: o transporte. Um dos reflexos do baixo investimento em infraestruturas de transporte é o "desbalanceamento" da matriz de transportes, concentrada, em grande parte, nas rodovias (2003, p. 41).

O Centro-Oeste e parte da região Norte compõem esses novos fronts, sendo as áreas que mais demandam investimentos em transportes, tanto rodoviários quanto ferroviários do país. Caso não sejam feitos, haverá uma estagnação do crescimento econômico por falta de capacidade de transportar a produção aos mercados consumidores. A matriz predominantemente rodoviária dos fronts encarece o preço final das mercadorias, principalmente pelo fato destes localizarem-se distantes dos portos brasileiros. Mais especificamente na região Centro Oeste é fácil perceber este fenômeno, pois a maior parte da produção ainda é transportada por rodovias. Ressalta-se que o estado de Goiás possui

\footnotetext{
${ }^{10}$ Fronts são áreas de moderna agricultura. Segundo Santos e Silveira (2001, p. 119) Nos fronts "amadurecem as inovações de ontem e chegam outras, próprias do período, para criar novos arranjos, com a resistência e a cooperação das rugosidades do lugar. (...) Nascem tecnificados, cientificizados, informacionalizados. Eles encaram uma situação: a da difusão de inovações em meio "vazio".
} 
proporcionalmente a melhor estrutura rodoviária da região, embora o Mato Grosso do Sul tenha uma maior estrutura ferroviária.

A definição da instalação das vias de acesso ao longo do território nacional não baseiase apenas com a estratégia geopolítica de ocupação e desenvolvimento do território. Ela ocorre sobretudo com o objetivo de promover a produção econômica a partir da identificação dos recursos regionais que acabam por configurar as vantagens concorrenciais. Desta forma, observa-se que o desenvolvimento não se dá apenas pela necessidade das sociedades, e sim, pela capacidade do capital em apropriar-se dos recursos naturais. Tais recursos localizam-se de forma espontânea sobre o território e aos poucos são convertidos em possibilidades de negócios lucrativos e impostos, e com isso, pode gerar benefícios para a nação.

Portanto, é preciso fazer com que a apropriação do território se justifique financeiramente a partir dos lucros produzidos nas atividades econômicas desenvolvidas pelas sociedades. Assim, tais sociedades serão beneficiadas pelas riquezas produzidas por essa ocupação, uma vez que sem a mão-de-obra tais recursos não seriam convertidos em dinheiro e lucro.

O estado recebe grande parte destes valores em impostos, além da própria valorização das áreas que passam a agregar valor na medida em que as infraestruturas são construídas. Certamente os valores recebidos pelos estados apenas em valorização das áreas são suficientes para cobrir boa parte das despesas gastas em seus empreendimentos. Sobre a construção de ferrovias, Aziz Ab' Saber (apud Santos, 2001) alertava sobre os desafios associados à construção de ferrovias e a especulação fundiária.

Ainda sobre esse assunto, Cano indaga "como podemos atender aos requisitos legítimos de recomposição da infraestrutura e da crise social se nos ativermos apenas às exigências dos interesses privados e internacionais" (1998, p. 352). Por isso, o estado ter que ser o regulador do processo, de modo a mediar os vários interesses envolvidos, sem contudo, perder o foco no benefício da sociedade.

Para refletir sobre tal indagação, Furtado percebe que a "predominância da lógica das empresas transnacionais na ordenação das atividades econômicas conduzirá quase necessariamente a tensões inter-regionais, à exacerbação de rivalidades corporativas e à formação de bolsões de miséria, tudo apontando para a inviabilização do país como projeto nacional" (2000b, p. 12).

Assim, é preciso que as políticas públicas sigam uma agenda de investimentos cujo foco seja sobretudo direcionado para o social. Com isso, evitar-se-á o emprego dos recursos 
públicos apenas para atender uma estratégia capitalista de exploração do território, onde o dinheiro tem que apenas gerar mais dinheiro. Caso contrário, o trabalhador seria duplamente expropriado, pois teria parte dos impostos que lhe são recolhidos e que deveriam lhe ser restituídos em forma de benefícios, sendo convertidos apenas em subsídios para a expansão capitalista.

Segundo Furtado (1969, p. 19) "o ponto de partida do estudo do desenvolvimento deveria ser, não a taxa de investimento, ou a relação produto-capital, ou a dimensão do mercado, mas sim o horizonte de aspirações da coletividade em questão". Certamente sem a expectativa do retorno financeiro não haverá motivação para que as grandes corporações arrisquem se na exploração dos recursos contidos nos territórios.

Por isso, quando investem grandes volumes de capitais, acabam determinando certas políticas públicas, e com isso, guiam as economias das nações, inclusive o Brasil. Pode se também analisar que os clichês tão conhecidos pela sociedade através da mídia, como o medo do desemprego, da inflação, da fome, da miséria e da violência, acabem justificando tal "sacrifício" do trabalhador, que acaba pagando com o seu trabalho.

Porém, jamais se pode esquecer que o cidadão é que deve ser o centro das estratégias de desenvolvimento. É preciso, portanto, questionar o modelo de apropriação econômica dos territórios, sobretudo a partir dos gastos com transportes e focar em modelos que sejam mais baratos, duradouros e eficientes, otimizando a contrapartida destinada ao contribuinte.

Deve-se questionar também a produção das notícias pela mídia a qual é, em muitos casos, patrocinada pelas grandes corporações para anestesiar os trabalhadores e favorecer a reprodução da alienação enquanto instância de dominação. Isso é muito comum quanto a apologia que é feita a favor do transporte rodoviário, especialmente o individual, em detrimento do coletivo. Visam vender carros.

O resultado são cidades e rodovias abarrotadas de veículos e os transtornos decorrentes são vários, como stress, perda de produtividade, desperdício, atraso, aumento dos custos das mercadorias e dos serviços, e enfim, perda de competitividade. Não há campanhas publicitárias que foquem em transporte coletivo, e muito menos em transportes ferroviários.

As políticas públicas quando existem, ainda são limitadas diante do atual cenário nacional e internacional. Por outro lado, os estados têm dificuldades em fugir dos interesses dos grandes investidores que acabam ditando as regras, principalmente no setor de transportes. O resultado é que o produto final de tal relação acaba sendo um serviço que visa o lucro excessivo, e ainda com baixa qualidade. 
Isso gera perda de eficiência no gasto público e onera o trabalhador que terá que arcar com os custos de serviços que deveriam ser prestados pelo estado, sobretudo nos transportes. Quem participa das decisões sobre os transportes no Brasil são outros agentes. Conheça no quadro abaixo cada agente do setor ferroviário no Brasil e seus interesses.

Quadro 3 - Interesses dos agentes do setor ferroviário no Brasil

\begin{tabular}{|ll|}
\hline Agente & Objetivos explícitos gerais \\
\hline Estado & Balança comercial \\
Agências reguladoras & Melhorar a eficiência e transparência do sistema \\
Concessionárias & Eficiência operacional/lucro \\
Investidores & Retorno sobre o investimento \\
Clientes & Menor custo de transporte \\
\hline
\end{tabular}

Fonte: Vencovsky (2003, p. 60)

Desta forma, os interesses existentes entre os agentes do setor ferroviário brasileiro são vários, de modo que o Estado se preocupa com a balança comercial, as agências reguladoras com a melhoria da eficiência e a transparência do sistema, as concessionárias com a eficiência operacional e o lucro, os investidores com o retorno sobre o investimento, e os clientes no menor custo de transporte.

Ou seja, o cidadão não participa das decisões, embora seja ele enquanto usuário direto ou indireto, que paga a conta. Assim, é a parte mais frágil, necessitando, portanto, da tutela estatal de fato e de direito. Isso é preciso para que no fim das contas se converta de forma eficiente o esforço da nação - impostos - em benefícios em prol da população.

Um exemplo de aumento de eficiência nos transportes, a partir de investimentos públicos é a ferrovia Norte Sul, pois além de contribuir para a diminuição do custo da produção, ainda atrai investimentos. O resultado é a geração de emprego e renda, principalmente quando se trata de interesses econômicos em empreendimentos logísticos desse porte e natureza.

Antes de mais nada a nação deve apropriar-se do território como forma de estabelecer uma melhor condição de vida. Para isso será necessária uma profunda reestruturação na forma de se pensar e entender o mundo, inclusive a própria relação do homem com o meio, na medida em que o foco não deve ser apenas a produção do lucro, mas principalmente, a 
qualidade de vida das sociedades. Ao construir a ferrovia Norte-Sul o estado brasileiro contribui com o crescimento da economia brasileira ao facilitar a logística do transporte de mercadorias no interior do país, criando condições para melhorar a vida da nação.

Evidencia-se que a lógica da produção define os investimentos em transportes e explica as razões que definem o traçado das ferrovias. De acordo com Isnard, “em tais condições já não é sobre o terreno que o geógrafo deverá procurar as chaves da explicação de uma organização espacial; a iniciativa está noutro lado, na capital ou no estrangeiro" (1982, p. 54). Sobre a relação entre investimento estatal e a atração de capitais internacionais, a VALEC chama a atenção para a capacidade da ferrovia em atrair grandes "trades" internacionais da produção de grãos. Observe:

\begin{abstract}
O papel catalisador de oportunidades geradas pelo binômio energia e transportes, pode ser comprovado no Polo Agrícola de Balsas (MA), onde a diretriz da Ferrovia Norte-Sul já está em operação, tem propiciado o crescimento da área plantada e, consequentemente, da produção de grãos, evidenciando a geração de empregos e renda, bem como a atratividade de investimentos privados. Do mesmo modo que o Pátio de Integração Multimodal de Porto Franco (MA), situado no quilômetro 190 da Ferrovia Norte-Sul, abriga as "trades" Bunge, Cargill e Multigrain, empresas que, atraídas pelas oportunidades oferecidas pelo transporte ferroviário, investiram cerca de US\$ 6 milhões em instalações para as operações de carga, transbordo e armazenagem de grãos (VALEC, 2011).
\end{abstract}

Ao destacar a presença de grandes multinacionais ao longo da ferrovia, materializa-se o propósito chave da apropriação e produção econômica no território. As empresas Bunge, Cargill e Multigrain ao investirem U\$ 6 milhões em instalações, certamente terão retornos muito maiores com a exploração dos serviços e produtos que serão gerados. Daí, compete ao estado estabelecer o equilíbrio entre os interesses diretos das grandes corporações nacionais e internacionais, e as necessidades da sociedade como um todo, diante da realidade vivida.

Vê-se, portanto que a análise da produção no território é real, especialmente no mundo globalizado. Sobre esta mundialização Santos (2003, p. 23), afirma que é o "ápice do processo de internacionalização do mundo capitalista". Por isso, é um processo que se manifesta no território nacional, mas as origens são predominantemente internacionais. Neste sentido, quando se faz uma releitura da apropriação dos territórios da nação, e em nosso caso, da intensificação desta no Brasil Central, fica evidente a expansão do capital nacional e internacional a partir da inserção das novas ferrovias. Tais vias possibilitam o acesso aos recursos existentes nos confins do território. Segundo Santos (2001, p. 22):

É nesse sentido que um território condiciona a localização dos atores, pois as ações que sobre ele se operam dependem da sua própria constituição. Uma preocupação 
com o entendimento das diferenciações regionais e com o novo dinamismo das suas relações tem norteado particularmente a busca de uma interpretação geográfica da sociedade brasileira.

O que é marcante em todo esse processo é que o estado não consegue conceber outra forma de gerar o desenvolvimento nacional a não ser investindo na economia como ponto de partida para se chegar à sociedade. Neste caminho, boa parte dos recursos quando não são desviados em esquemas de corrupção, muitas vezes acabam contemplando mesmo as grandes corporações, ou seja, o grande capital. Como diria Milton Santos, "o capital em estado puro é na verdade o grande fundamentalismo" (TENDLER, 2006).

Portanto, deve se pensar em "uma outra" possibilidade de entendimento do processo econômico hegemônico, onde o grande fundamentalismo seja a defesa da qualidade de vida da nação, e que as riquezas geradas pela nação sejam convertidas às demandas sociais. As ferrovias têm um papel direto neste processo, pois além de melhorar a competitividade econômica, ainda contribui para a diminuição dos acidentes nas rodovias ao diminuir as demandas de transportes em caminhões.

Esta linha de pensamento estabelece uma íntima ligação entre a produção do território segundo as concepções de Milton Santos, na medida em que se pensa o território como condição para o atendimento das necessidades da sociedade, e não apenas para a geração do lucro. Infelizmente em muitos casos, apenas os interesses de grupos hegemônicos, que acabam de forma direta ou indireta controlando os transportes, é que são atendidos.

Isso se deve principalmente ao fato de que as grandes corporações internacionais que têm suas sedes nos países desenvolvidos, conseguirem apropriar-se de parcelas dos territórios de nações menos desenvolvidas. Assim, produzem mercadorias de acordo com seus interesses econômicos, e as envia para os mercados que melhor lhes convier. Esse "possibilismo logístico" cada vez mais suplanta o determinismo geográfico, conforme discutido por David Harvey (2007) na obra Condição Pós Moderna. Sobre esse assunto, Santos observa que:

As ações são cada vez mais estranhas aos fins próprios do homem e do lugar. Daí a necessidade de operar uma distinção entre a escala de realização das ações e a escala do seu comando. Essa distinção se torna fundamental no mundo de hoje: muitas das ações que se exercem num lugar são o produto de necessidades alheias, de funções cuja geração é distante e das quais apenas a resposta é localizada naquele ponto preciso da superfície da Terra (2002, p. 80).

Assim sendo, a discussão sobre o papel do Estado no crescimento da economia não pode limitar-se apenas às políticas de transportes, mas sobretudo, na regulamentação do mercado de modo a direcionar as vantagens adquiridas neste processo para a geração de benefícios para a sociedade. Trazendo para o tema em discussão, é preciso pensar uma 
reordenação territorial ${ }^{11}$ brasileira a partir das ferrovias. Destaca-se entre as recém construídas, a Norte-Sul, objetiva mais do que lucros, uma vez que tem proporcionando principalmente benefícios possíveis de serem estendidos a toda sociedade brasileira.

A edição de um novo marco regulatório para o modal, durante a vigência daquele que regula as atuais concessões, gera dúvidas no setor e pode inibir investimentos tanto das atuais concessionárias quanto das possíveis entrantes. São dois os principais riscos associados ao modelo apresentado no PIL em relação à VALEC comprar toda produção da nova malha: primeiro, o novo modelo pode reduzir o incentivo à busca por maior eficiência e ganhos de gestão por parte das operadoras, que terão um mercado cativo; e segundo, o elevado compromisso financeiro assumido pelo Estado para arcar com a compra da produção pode ser insustentável no longo prazo, e essa possibilidade pode afastar investidores das licitações. Assim,

Para viabilizar a modernização e o crescimento da malha serão necessários - além de incentivos à participação da iniciativa privada - planejamento e comprometimento do ente estatal no que se refere tanto aos investimentos públicos quanto à garantia de estabilidade institucional (CNT, 2013: 41).

Por fim, o modelo de concessão precisa ser analisado com cuidado, pois em um mundo globalizado e neoliberal, deve prevalecer a livre concorrência enquanto principal elemento motivador do aperfeiçoamento do serviço. Se o Estado compra toda a produção da empresa prestadora de transportes, automaticamente tornará sem sentido a busca por um serviço mais eficiente, uma vez que independente da qualidade apresentada, ele será comprado. Por outro lado, a garantia da compra do serviço sem a necessária utilização deste, poderá acarretar grandes gastos por parte do Estado, e em longo prazo, pode se tornar inviável e entrar em colapso.

Desta forma, gera insegurança por parte dos investidores, que terão reservas em investir elevados volumes financeiros em um empreendimento cujo retorno será demorado, e que não tem garantias sólidas de durabilidade. Independentemente dos desafios apresentados no setor ferroviário, não há como retroagir tendo em vista a íntima ligação entre a permanência do país no seleto grupo das nações mais desenvolvidas, e a eficiência logística proporcionada pelas ferrovias. O setor de transporte ferroviário é um fator de transformação econômica. São

\footnotetext{
${ }^{11} \mathrm{O}$ ordenamento territorial pode ser entendido como um modelo de gestão do território utilizado para garantir um padrão de desenvolvimento para o País, os estados e as regiões. De uma maneira racionalista, políticas públicas passam a organizar o espaço de forma integrada para atender alguns objetivos, como o desenvolvimento regional, o uso do território e a melhora das condições de vida da população. Diferentemente do verificado na Europa, o Brasil ainda não dispõe de uma lei nacional de ordenamento do território (DUARTE, 2002).
} 
diversas as possibilidades de ganhos derivados de uma maior utilização do modal ferroviário para o transporte de cargas (CNT, 2013).

Seu baixo custo apresenta vantagens para o Brasil, que cada vez mais se consolida como o principal exportador mundial de produtos agrícolas e minerais. As características físicovolumétricas desses bens fazem com que haja escala no transporte ferroviário, gerando economias para os produtores e competitividade no mercado internacional. O elevado nível de segurança também caracteriza o transporte ferroviário, pois o risco de acidentes envolvendo terceiros ou as próprias locomotivas é baixo. Além da grande capacidade de carregamento, a baixa emissão de poluentes das composições e o menor impacto ambiental na construção da infraestrutura fazem com que o modal ferroviário apresente custos ambientais reduzidos.

Todo esse acervo de vantagens competitivas somente é possível com as ferrovias. Assim sendo, qualquer nação que queira manter-se no seleto grupo das maiores potências econômicas mundiais deve possuir uma moderna estrutura ferroviária. Isso se deve, sobretudo ao fato de ser hoje, o melhor modal de transportes terrestres de grande volume agregado do planeta. Pode ser que no futuro surja outro. Todavia, nos tempos atuais, o modal ferroviário é o mais barato quando se trata de transportes terrestres, pois é o mais barato, mais seguro e que menos impacta o ambiente. No caso brasileiro, há como fazer ainda melhor, principalmente quanto os entraves que ainda existem forem sanados.

Apesar dos benefícios apresentados, as vantagens do modal não são integralmente aproveitas pela existência de diversos entraves. Mesmo com o grande volume de recursos contemplados no PAC transportes e no PIL para as ferrovias, nem todos os projetos programados foram iniciados, e diversos empreendimentos já em construção ultrapassaram seus limites orçamentários e tiveram seus prazos de conclusão estendidos. Isso compromete a expansão da logística ferroviária no país e reduz as vantagens que os produtos exportados apresentam, em especial os do agronegócio.

Não obstante, as concessões ferroviárias foram capazes de promover diversas mudanças qualitativas no sistema ferroviário nacional, como o aumento da produtividade, a redução no nível de acidentes e o aumento do investimento na malha existente. De acordo com a CNT (2013, p. 41)

\footnotetext{
As novas concessões de ferrovias anunciadas pelo Governo Federal são um grande avanço para o setor de transporte, pois poderão ser capazes de viabilizar a expansão da malha ferroviária e sua manutenção e operação pela iniciativa privada. Assim, além de desonerar o Orçamento Público, as novas concessões tendem a promover a continuidade dos ganhos de eficiência já verificados no setor.
} 
Nota-se que o Brasil, em função das suas dimensões continentais e por possuir a maior quantidade de solos agricultáveis do planeta, necessita de ferrovias para atender as grandes demandas de deslocamento de cargas em grandes distâncias. É importante não apenas para a competitividade do país em nível internacional, mas também para a integração econômica da nação, contribuindo para um desenvolvimento mais equilibrado e harmônico, distribuindo riqueza e renda.

Outro aspecto fundamental é a possibilidade de favorecer os cidadãos na medida em que se converte a potencialidade dos recursos naturais em resultados econômicos positivos, os quais poderão atender as demandas da sociedade, possibilitando melhor qualidade de vida. Por isso, mesmo que a rede ferroviária brasileira apresente problemas e limitações, ainda assim ela é necessária para criar condições de uma boa competitividade logística, e consequentemente melhorar o crescimento econômico. 


\section{CONCLUSÕES}

Diante do exposto observa-se que o processo de implantação e expansão das ferrovias expressa a própria modernização do meio técnico científico, enquanto necessidade da incorporação dos territórios pela economia internacional. Representa a resposta do capital para sua reprodução, e ao mesmo tempo em que motiva, também é motivada pela lógica do crescimento econômico, este, entendido como a resposta para a evolução da humanidade e a solução dos seus problemas.

O processo de modernização dos transportes em nível mundial, expressa, portanto, a capacidade humana de resolver problemas, e de estabelecer competições que resultam na elevação de povos e nações à condição de líderes econômicos e políticos do globo. Ou seja, mais do que respostas aos problemas das sociedades, a modernização dos meios de transportes define, juntamente com o domínio das comunicações de ponta, a liderança da economia mundial.

Assim, ao compreender a geografia política das nações e os esforços destas para o estabelecimento de uma eficiente geopolítica dos transportes, que vise a integração e coesão dos territórios, pode-se entender a íntima relação entre logística, modernidade e desenvolvimento. A geopolítica na medida em que alia os estudos e aplicação de estratégias que integrem a apropriação econômica dos territórios a partir da lógica do mercado internacional, somente é possibilitada pela existência de adequadas infraestruturas de transportes.

A constituição espacial a partir do entendimento da forma, do processo, da estrutura e da função, explica o funcionamento dos transportes. A forma das vias sobre o território e seu relevo, para atender o processo econômico internacional, transportando mercadorias e pessoas, a partir de toda a estrutura envolvida, tanto física, seja fixa ou móvel, e também de pessoal, materializa a sua função de articular a mobilidade da reprodução do capital. Tal reprodução define o trabalho das sociedades, seus papéis, a intensidade e intencionalidade do seu esforço e se estabelece como a solução para os problemas sociais.

Desta forma, a lógica econômica define-se como hegemônica no final do último quinto do século XX e início do XXI, e substitui a ótica internacional do mundo ao longo dos primeiros 80 anos do século XX, que caracterizou-se por uma disputa de força política e militar. Não que a econômica não fosse importante, mas se difere pelo uso dela como um dos fatores que resultem em poder, principalmente após a Revolução Industrial, culminando na 
definição das nações mais poderosas politicamente do globo. Com o fim da Guerra Fria, marcada pela queda do muro de Berlim em 1989 e pelo fim da URSS em 1991, o capitalismo torna-se hegemônico, e paulatinamente converte a importância do poder econômico de secundário para principal. O poder político que até então era o propósito fim das relações de forças da geopolítica mundial é substituída pela ótica econômica, e então, inverte essa relação e passa a empregar o político como ferramenta para o crescimento econômico.

O econômico ao se tornar hegemônico converte os territórios das nações em instrumento da sua reprodução e define a condição do ranking dos países na medida em que estes conseguem desenvolver formas de manterem-se na vanguarda tecnológica dos processos produtivos, nos transportes, nas comunicações e na acumulação de capitais. Por isso, ser economicamente desenvolvido é a condição para a evolução das sociedades e a solução dos seus problemas. É a fase do desenvolvimento técnico, científico e informacional, esta guiada sobretudo pela economia.

Uma das expressões da modernidade são as ferrovias, e por elas o Brasil Central passa a ser incorporado desde o final do século XIX e início do XX. As vias chegam de São Paulo e ganham ênfase a partir da Era Vargas, com as novas estratégias geopolíticas de incorporação do território nacional. Em consequência, destaca-se o incremente demográfico no Brasil Central, de modo que a partir de 1930 a construção da nova capital do Estado de Goiás, a cidade de Goiânia, que passa a ser um símbolo de modernidade no interior do país. As inovações destacaram-se especialmente pela implementação de um arrojado projeto urbanístico e arquitetônico, que agregou elementos da Era de Versalhes, a concepção de Cidades Jardim, e também, a Art Déco de origem francesa.

Mais que uma nova capital para o Estado de Goiás, Goiânia passa a ser o símbolo da modernidade desejada pelos governantes brasileiros. Ressalta-se que as primeiras ferrovias atingiram o território goiano em 1913, a partir da extensão dos trilhos da ferrovia Mogiana, que vinham da cidade mineira de Araguari. A nova ferrovia foi chamada de Estrada de Ferro Goiás e alcançou paulatinamente várias cidades de sudeste goiano, alcançando posteriormente Anápolis em 1930 e Goiânia em 1950. Mais tarde, com a construção e inauguração da nova capital federal, entre os anos de 1957 e 1960, os trilhos chegaram até Brasília.

Entretanto, juntamente com a construção de Brasília ocorre um redirecionamento nas políticas de transportes do país, que passam a priorizar o transporte rodoviário, em detrimento do ferroviário. A maior flexibilidade e o menor custo para o deslocamento de cargas de pequena quantidade, ocasionou a desativação de vários ramais ferroviários que passaram a ser 
considerados antieconômicos. Desde então, as ferrovias diminuíram paulatinamente o seu papel no transporte de passageiros e de cargas diante da concorrência com o transporte rodoviário. Em longo prazo a falta de investimentos nas ferrovias resultou em dificuldades estruturais. Tais dificuldades levaram várias empresas do ramo a falência e a incorporação delas pelo Estado. Com isso, mais tarde, tais ferrovias deram origem a Rede Ferroviária Federal S/A - RFFSA e a Ferrovias Paulistas S/A - FEPASA.

A partir dos anos 1980 as ferrovias brasileiras passaram por cortes em seus orçamentos, em função da escassez na arrecadação de impostos, provocada pelas crises vividas pela economia mundial. Com isso, os transportes sobre trilhos nos centros urbanos passaram para a administração local, enquanto que as demais ferrovias foram privatizadas ao longo da década de 1990. Após a privatização, vários investimentos foram feitos, outros ramais deficitários foram desligados e praticamente todas as linhas de transporte intermunicipal e interestadual de passageiros foram desativadas, e suas estações abandonadas. $\mathrm{O}$ foco passa a ser o transporte de cargas de grande volume e com baixo valor agregado, como minérios e grãos, em longas distâncias. O novo modelo de gestão alcançou bons resultados e conseguiu aumentar a produção do transporte de cargas, diminuiu o índice de acidentes, recuperou paulatinamente a infraestrutura rodante e dos trilhos, e ainda, aliviou os gastos públicos nas ferrovias.

Desde então o Estado passou a investir na expansão da malha, construindo novas e modernas ferrovias para integrar as já existentes, a fim de melhorar a competitividade da economia brasileira a partir de uma melhor infraestrutura de transportes. O grande símbolo de nova etapa é a Ferrovia Norte-Sul - FNS, que tem a função de integrar as malhas das regiões Norte e Nordeste, com as malhas do Centro Oeste, do Sudeste e do Sul do Brasil. A maior parte da nova ferrovia está localizada nos estados do Tocantins e Goiás, situados no Brasil Central. Além de integrar as malhas já existentes, a Norte-Sul ainda será responsável pela ligação e articulação de novas ferrovias que estão em construção, como a Ferrovia de Integração Oeste Leste - FIOL, a Ferrovia Transnordestina, a Ferrovia de Integração do Centro Oeste - FICO e a Ferrovia Transcontinental.

A FICO ligará os polos produtores de soja do Centro Oeste brasileiro até a Ferrovia Norte Sul, na cidade de Campinorte - GO, e por ela ao Porto de Itaqui no Maranhão, ou aos portos do Sudeste. Posteriormente ela seguirá, na outra ponta, até a cidade de Boqueirão da Esperança - AC, constituindo parte da Ferrovia Transcontinental. Esta por sua vez, parte da 
cidade Campos - RJ, atravessará Minas Gerais, Distrito Federal e conectará a FNS em Uruaçu $-\mathrm{GO}$.

Pela FNS ela seguirá até Campinorte, ligando se a FICO. Já a FIOL partirá de Ilhéus BA, cruzará a região produtora de grãos do oeste baiano e conectará a Ferrovia Norte Sul na cidade de Figueirópolis - TO. Outra importante ferrovia é a Transnordestina que dá continuidade às malhas do Nordeste que ligam os portos de Pecém - CE e Suape - PE, atravessando vários estados nordestinos, à Ferrovia Norte Sul na altura da cidade de Estreito Maranhão, divisa com o Tocantins.

Por fim, a FNS atualmente já está pronta desde a cidade de Açailândia - MA até a cidade de Anápolis - GO. Em Açailândia, a FNS se liga com a Estrada de Ferro Carajás, que segue até o Porto de Itaqui - MA. Já em Anápolis, a FNS, liga-se com a malha da Ferrovia Centro-Atlântica - FCA, a qual faz parte de Grupo VLI, e conecta-se aos principais portos do Sudeste brasileiro, inclusive o Porto de Santos. Ressalta-se que a FNS será estendida ao norte, ligando a cidade de Açailândia até a cidade paraense de Barcarena, às margens do Rio Amazonas. Ao sul a FNS, terá seus trilhos alongados de Anápolis até a cidade de Rio Grande - RS, passando pelos estados de Minas Gerais, São Paulo, Paraná, Santa Catarina e Rio Grande do Sul.

Ao evidenciar a importância dos transportes na contemporaneidade, conclui-se que o estado brasileiro está adequando a estrutura logística brasileira, sobretudo a partir das ferrovias, pois elas possuem o melhor preço para o deslocamento de cargas, acima de 40 toneladas e em distâncias superiores a 320 quilômetros. Portanto, além do incremento da integração nacional, o país está modernizando sua estrutura produtiva, diminuindo os custos, aumentando sua competitividade em nível internacional, e ainda, aliviando as rodovias. Com isso, destina as rodovias para o transporte de cargas de menor volume e em menores distâncias, e também, para o deslocamento de veículos de passeio, os quais aumentaram consideravelmente nos últimos anos em função do crescimento econômico e populacional da nação.

Outro fator marcante é a localização dos entroncamentos das novas ferrovias que concentraram-se nos estados de Goiás e Tocantins, localizados no Brasil Central. Tais estados foram privilegiados pois além dos investimentos atraídos pela incorporação de áreas de seus territórios ao circuito econômico internacional, ainda poderão beneficiar-se da instalação de indústrias, principalmente aquelas vinculadas ao agronegócio. 
Neste sentido, Goiás foi agraciado com a proximidade às áreas das indústrias e do mercado consumidor das regiões Sudeste e Sul, e ainda, a possibilidade de receber também indústrias de produção de bens de consumo duráveis, como montadoras de automóveis e motocicletas. Neste sentido Goiás se transformou em um verdadeiro entroncamento logístico nacional, não apenas pelas rodovias que partem de Brasília em todas as direções do país, mas sobretudo, pelas ferrovias existentes em terras goianas que passam a integrar as malhas férreas de todas as regiões brasileiras.

Enfim, a correlação entre a necessidade de integração do extenso território nacional e a articulação da economia através de transportes eficientes, caracteriza a geopolítica dos transportes no Brasil. A lógica desse processo perpassa pela necessidade de desenvolvimento da economia, sendo esta determinante para a definição das estratégias de ocupação das regiões brasileiras a partir das suas vocações econômicas, e ainda, da capacidade da nação em competir em nível internacional. A isso chamamos de produção econômica do território, entendida como a forma determinante e até certo ponto impositiva de direcionar esforços nacionais de toda ordem para garantir o seu sucesso.

Essa forma de hierarquizar e priorizar os recursos da nação define os papéis dos cidadãos e o tipo de uso e ocupação do território, com vistas ao sucesso econômico. Na contemporaneidade, isso é o que Milton Santos afirmou com o "grande fundamentalismo". Ou seja, tudo o que é entendido enquanto desenvolvimento, deve partir do econômico para chegar ao social e ao ambiental, refletindo uma nova ótica da geopolítica contemporânea. Desta forma, as transformações espaciais são sobretudo reflexos da produção econômica do território. E a modernização desta produção econômica do território ocorre sobretudo em função das ferrovias.

Em síntese, das hipóteses elencadas no início da pesquisa, constatou-se que algumas foram confirmadas, e outras em parte refutadas. A ideia de que Goiás se tornou o novo entroncamento logístico ferroviário nacional foi confirmado, uma vez que mesmo não sendo o maior e por enquanto não é o mais importante, pois este papel ainda é de São Paulo, por outro lado as articulações férreas em solo goiano possibilitam uma gama de conexões entre os ecúmenos do país e os principais portos brasileiros de modo extremamente versátil e inovador. A diversidade de rotas possíveis a serem usadas é um assunto ainda a ser discutido.

A hipótese do Estado ser o grande articulador da logística nacional, foi em parte refutado. As ferrovias no Brasil foram construídas a partir do século XIX pela iniciativa privada, e não pelo Estado, para que pudessem atender as necessidades de transportar 
mercadorias das zonas produtoras, até os centros de consumo, ou aos portos para exportação. O Estado, no início, restringiu-se a apenas regulamentar as construções e a exploração dos serviços prestados. Em períodos de crise econômica, o Estado foi acionado para cuidar da estrutura ferroviária, de forma que os serviços não parassem de funcionar, mesmo que para isso, devesse trabalhar com déficits. O resultado foi a estatização da malha ferroviária, que por algumas décadas, passou para o controle do Estado.

Posteriormente, com o crescimento e fortalecimento da economia após a Segunda Guerra, o controle das ferrovias voltou para a iniciativa privada, que assumiu o papel de operar as redes e modernizar o sistema. Ou seja, o setor privado, por ser o que mais se beneficia, é também o maior interessado pelas ferrovias, sobretudo quando se trata de transporte de mercadorias com grande volume e baixo valor agregado. Considerando que em cargas de menor quantidade e em distâncias mais curtas, as rodovias são mais baratas que as ferrovias, observa-se que o transporte rodoviário tem vantagem quanto ao ferroviário, inclusive ao se tratar de passageiros. Para quem precisa deslocar-se a distâncias maiores, o transporte aéreo tornou-se mais barato, acessível e constitui a melhor alternativa, sobretudo pela rapidez ao transpor grandes trajetos.

Desta forma, cada vez mais as ferrovias estão destinadas à logística de cargas, e não de passageiros. Recomendo que estudos sejam feitos com o intuito de aprofundar nesta discussão, de modo a buscar em outros países que usam o transporte ferroviário interestadual, de longas distâncias, modelos que possam ser aproveitados no Brasil. Embora empregados em grande escala nas principais metrópoles brasileiras, há poucas linhas que operam o transporte intermunicipal e interestadual de passageiros, as quais atuam por ausência de rodovias no trecho, como a Estrada de Ferro Carajás ou com fins turísticos, sendo as principais a Vitória Minas, Curitiba - Morretes - Paranaguá, e o pequeno trecho da Madeira Mamoré. Recomendo também os estudos sobre a utilização de trechos ferroviários desativados em várias partes do Brasil, para fins turísticos e culturais, os quais podem se tornar importantes ferramentas para o fortalecimento da cultura e da identidade além do conhecimento da história nacional.

Como Goiás nunca deixou de ser um importante articulador nacional, devido ao seu posicionamento central no país, função ampliada com as rodovias e agora com o incremento das ferrovias, recomendamos também estudos mais detalhados sobre a possibilidade de rotas logísticas sobre o território que passam por este estado. Sugerimos ainda o uso estratégico dos entroncamentos ferroviários nacionais que chamamos aqui de Setentrional, Central e 
Meridional, para a implantação de estruturas produtivas de grande porte, vinculadas às vocações e possibilidades regionais, de modo a incrementar o crescimento da economia brasileira.

No âmbito da geografia, recomendo o aprofundamento dos estudos sobre os transportes, os deslocamentos de mercadorias e pessoas sobre o território, e também nos grandes centros, de modo a favorecer a busca por menores preços, modais mais baratos, rápidos, seguros e eficientes. É importante valorizar o transporte de massa de qualidade que seja desejável tanto para pessoas como para mercadorias, buscando o equilíbrio diante da hegemonia rodoviária, para que além da economia, o meio ambiente e a qualidade de vida sejam atendidos. 


\section{REFERÊNCIAS}

ABLAS, L. O "Estudo dos Eixos" como Instrumento de planejamento regional. In: GONÇALVES, M.F.; BRANDÃO, C.A.; GALVÃO, A.C.F. (Org.). Regiões e cidades, cidades nas regiões. O desafio urbano-regional. São Paulo: Unesp, 2003.

AMANTES DA FERROVIA. Disponível em <http://www.amantesdaferrovia.com.br/>, acessado em 06 mar 2014.

ANTF. Material Rodante: locomotivas e vagões. Disponível em <http://www.antf.org.brindex.php/ material-rodante>, acessado em 27 jun. 2014.

ANTT. Evolução do Transporte Ferroviário. Brasília: Ministério dos Transportes, 2012. Acessado em <http://www.antt.gov.br/concessaofer/apresentacaofer.asp>, acessado em $23 \mathrm{fev}$ 2013.

ANPF. O Sesquicentenário da Ferrovia no Brasil - V A primeira ferrovia inaugurada no Brasil. A História nos Trilhos. Abril de 2004, $\mathrm{n}^{\circ}$ 20. Disponível em <http://www.anpf.com.br/histnostrilhos/historianostrilhos20_abril2004.htm>, acessado em 03 mar 2014.

ALVES, Leonardo Ramalho Rodrigues. O Arquipélago Brasil e a manobra estratégica em linhas interiores: uma proposta estratégica militar baseada em especulações geopolíticas. $A$ Defesa Nacional, ano CX, no 799, mai/ jun/ jul/ ago 2004. Rio de Janeiro: BIBLIEX, 2004.

ARQUIVO PÚBLICO DO ESTADO DE SÃO PAULO. Ferrovias Paulistas. Disponível em < http://www.arquivoestado.sp.gov.br/exposicao_ferrovias/fepasa.php>, acessado em 25 mar 2014.

ARRAIS, Tadeu Alencar. Geografia contemporânea de Goiás. Goiânia: Ed. Vieira, 2004.

BARREIRA, Celene Cunha Monteiro Antunes. Vão do Paranã: a estruturação de uma região. Brasília: Ministério da Integração Nacional: Editora da Universidade Federal de Goiás, 2002.

BECKER, Bertha K. A geopolítica na virada do milênio: logística e desenvolvimento sustentável. CASTRO, Iná Elias et al. Geografia: conceitos e temas. Rio de Janeiro: Bertrand Brasil, 1995.

BECKER, Bertha K., EGLER, Cláudio A. G. Brasil: uma nova potência regional na economia mundo. Rio de Janeiro: Bertrand Brasil, $3^{\text {a }}$ ed., 1998.

BRZEZINSKI, Zbigniew. EUA e URSS: o grande desafio. Rio de Janeiro: Nórdica, s.d. BORGES, Barsanufo Gomides. Goiás nos quadros da economia nacional: 1930 - 1960. Goiânia: Ed. da UFG, 2000.

CANO, W. Desequilíbrios regionais e concentração industrial no Brasil, 1930 - 1995. Campinas, SP: UNICAMP-IE, 1998. 
CASTRO, João Alves de. O Estado e a apropriação do território de Goiás. NETO, Antônio Teixeira et al. O espaço goiano: abordagens geográficas. Goiânia, Associação de Geógrafos Brasileiros, 2004.

CASTRO, Terezinha de. Geopolítica, princípios, meios e fins. Rio de Janeiro: Biblioteca do Exército ed., 1999. 1986.

Retrato do Brasil: Atlas texto de geopolítica. Rio de Janeiro; Biblioteca do Exército,

CNT. O Sistema Ferroviário Brasileiro. Brasília: CNT, 2013.

DIAS, Leila Christina. Redes: emergência e organização. In: CASTRO, Iná Elias de; GOMES, Paulo César da Costa e CORRÊA, Roberto Lobato. (org.). Geografia: Conceitos e Temas. Rio de Janeiro: Bertrand, 2002.

DUARTE, A. T. S. O ordenamento territorial como base para uma nova política de desenvolvimento semiárido. Brasília: Câmara dos Deputados, 2002.

ESTAÇÕES Ferroviárias do Brasil. Disponível em <http://www.estacoesferroviarias.com.br/efl_rj_petropolis/guia.htm>, acessado em 03 mar 2014.

ESTEVÃO, Luiz. O tempo da transformação - estrutura e dinâmica da formação econômica de Goiás. Goiânia: Ed. da UCG, 2004.

FCA. Diagrama Unifilar da FCA. Disponível em <http://www.fcasa.com.br/>, acessado em 04 Dez 2011.

FROTA, Guilherme de Almeida. Quinhentos Anos de História do Brasil. Rio de Janeiro: Biblioteca do Exército, 2000.

FURTADO, C. Um projeto para o Brasil. Rio de Janeiro: Saga, 1969.

. O mito do desenvolvimento econômico. Rio de Janeiro: Paz e Terra, 1974.

O fator político na formação nacional. Estudos Avançados, São Paulo, v. 14, n. 40, p. 7-12, set./dez.2000.

GOMES, Horieste et. al. Geografia Goiás-Tocantins. Goiânia: Editora da UFG, 2004.

HARVEY, David. A Condição Pós-Moderna. 16ª edição. São Paulo: Edições Loyola, 2007.

IBGE. Enciclopédia dos Municípios Brasileiros. Goiás. Rio de Janeiro: IBGE, 1995, V. 36. . I Centenário das Ferrovias Brasileiras. Rio de Janeiro: IBGE, 1954.

INOCÊNCIO, Maria Erlan. Algumas reflexões sobre o crescimento / estagnação de Ipameri Goiás a partir das ferrovias. Espaço em Revista. Catalão: Editora da UFG, 2000. p. 93 - 103.

ISNARD, H. O espaço geográfico. Coimbra: Portugal: Almerinda, 1982. 
LACOSTE, Yves. A geografia - Isso serve em primeiro lugar para fazer a guerra. $4^{\mathrm{a}} \mathrm{ed}$. Campinas, SP: Papirus, 1997.

LENHARO, Alcir. A Sacralização da Política. Campinas: Editora da UNICAMP, 1986.

MAGNOLI, Demétrio. O Corpo da Pátria: imaginação geográfica e política externa do Brasil (1808 - 1912). São Paulo: Editora da Universidade Estadual Paulista: Moderna, 1997.

MARTINS, José de Souza. Fronteira - a degradação do outro nos confins do humano. Hucitec. São Paulo, 1997.

MELLO, Leonel Itaussu Almeida. Quem tem medo da geopolítica? São Paulo: Hucitec; Edusp, 1999.

MENDONÇA FILHO, Marajá João Alves de. Influências geopolíticas e defesa nacional: quartéis do Exército na região de cerrado de Goiás, Tocantins, Distrito Federal e Triângulo Mineiro. Dissertação de Mestrado. Goiânia: Impresso, 2005.

MERLIN, P. Geografia des Transports, Que sais-je ? Paris: Presses Universitaires de France, 1992.

MINISTÉRIO DE MINAS E ENERGIA - Brasil. Consolidação de Bases de Dados do Setor Transporte : 1970 - 2010. Nota Técnica SDB - Abast nº 1/2012. Brasília, 2012.

MINISTÉRIO DOS TRANSPORTES - Brasil. Banco de Informações e Mapas de Transportes. Disponível em <http://www2.transportes.gov.br/bit/03-ferro/ferro.html>, acessado em 27 mar 2014.

MIYAMOTO, Shiguenoli. Geopolítica e Poder no Brasil. Campinas, SP: Papirus, 1995.

MONBEIG, Pierre. Pioneiros e fazendeiros de São Paulo. 2aed. São Paulo: Hucitec, 1998. . O Brasil. São Paulo: Difusão Européia do Livro, 1971. Ensaios de Geografia Humana Brasileira. São Paulo: Martins Fontes, 1940.

NUNES, Ivanil. Ferrovia brasileira: concessão pública para uso privado. Revista IberoAmericana de Estratégia, América do Norte, 5, dez. 2007. Disponível em: http://www.revistaiberoamericana.org/index.php/ibero/article/view/136. Acesso em: 16 Abr. 2012.

PIMENTEL, Sidney Valadares e AMADO, Janaína. Passando dos Limites. Goiânia: Editora da UFG, 1995.

RAFFESTIN, Claude. Por uma Geografia do Poder. São Paulo: Ática, 1993.

REZENDE, Maria Efigênia de. Atlas Histórico do Brasil. Belo Horizonte: Vigília, 1987. 
RESENDE, Paulo Tarso Vilela de, OLIVEIRA, Marcos Paulo Valadares e SOUSA, Paulo Renato de. Análise no modelo de concessão no transporte ferroviário brasileiro: a visão dos usuários. Anais do SIMPOI. São Paulo: FGV, 2009.

SANTOS, Milton e SILVEIRA, Maria Laura. O Brasil: Território e Sociedade no início do século XXI. Rio de Janeiro: Record, 2001.

SANTOS, Milton. Geografia e Planejamento: o Uso do Território - Geopolítica. Revista Eletrônica: Tempo - Técnica - Território, V.2, N. 2, Brasília (2011), P. 1: 49.

Por uma outra globalização: do pensamento único à consciência universal. Rio de Janeiro: Record, 2003.

. A natureza do espaço. São Paulo: Edusp, 2002.

SEGPLAN. Dinâmica Populacional de Goiás: Análise de Resultados do Censo Demográfico $2010-I B G E$.

SENA, Clóvis. Fronteira Centro-Oeste. Goiânia: Kelps, 1999.

SILVA, Golbery do Couto e. Geopolítica do Brasil. Rio de Janeiro: Livraria José Olympio Editora, 1981.

SILVA, Moacir M. F. Geografia das Estradas de Ferro Brasileiras em seu Primeiro Centenário. (in) IBGE. I Centenário das Ferrovias Brasileiras. Rio de Janeiro: Serviço Geográfico do Instituto Brasileiro de Geografia e Estatística, 1954.

SIMIELLI, Maria Elena. Geoatlas, 31ª ed. São Paulo: Ática, 2002.

SORJ, Bernardo. Estado e Classes Sociais na Agricultura Brasileira. Rio de Janeiro: Zahar, 1980.

SOUZA, Candice Vidal e. A Pátria Geográfica: sertão e litoral no pensamento social brasileiro. Goiânia: Ed. da UFG, 1997.

SOUZA Marcelo José Lopes de. O território: sobre espaço e poder, autonomia e desenvolvimento. In: CASTRO, Iná Elias de; GOMES, Paulo César da Costa e CORRÊA, Roberto Lobato. (org.). Geografia: Conceitos e Temas. Rio de Janeiro: Bertrand, 2002.

STEINBERGER, Marília. Região Centro-Oeste: uma visão geopolítica. Revista Sociedade e Cultura. Dossiê Políticas Públicas (Editor Pedro Célio Borges). Universidade Federal de Goiás - V.3, n. 1/2 jan / dez 2000, pp. 31 - 49. Territórios Turísticos do Brasil Central. Brasília. LGE Editora, 2009.

TENDLER, Sílvio. Encontro com Milton Santos ou o Mundo Global Visto de Cá (documentário). Brasil, 2006. 86 minutos. DVD. Cor. 
UNIVERSO LOGÍSTICO. Mapa das principais ferrovias brasileiras. Disponível em <http://gestaodacadeiadesuprimento.blogspot.com.br/2011/05/mapa-das-principaisferrovias.html>, acessado em 26 mar 2014.

VALEC. Diagrama Unifilar da Ferrovia Norte Sul - FNS. Disponível em <http://www.valec.gov.br/acoes_programas/FNSFerroviaNorteSul.php>, acessado em 29 jan 2015 .

- Inaugurados 855 quilômetros da Ferrovia Norte-Sul. Disponível em <http://www.valec.gov.br/noticias/Noticia220514>, acessado em 24 maio 2014a.

Mapa atualizado das Ferrovias. Disponível em <http://www.valec.gov.br/>, acessado em 05 mar 2014b.

Mapa atualizado das Ferrovias. Disponível em <http://www.valec.gov.br/>, acessado em 23 fev. 2013.

Elaboração de Estudo de Viabilidade Técnica, Econômica e Ambiental (EVTEA) para implantação de trechos ferroviários da EF 151: segmento 2 ligação Goiânia/GO Anápolis/GO - Brasília/DF. Recife, VALEC: 2012.

$03 \mathrm{dez} 2011$.

Ferrovia Norte - Sul. Disponível em <http://valec.gov.br/ferrovia.htm>, acessado em

VELHO, Otávio G. Frentes de Expansão e Estrutura Agrária. Rio de Janeiro: Zahar Editores, 1972.

VENCOVSKY, Vitor Pires. Sistema Ferroviário e o uso do território brasileiro. Uma análise do movimento de produtos agrícolas. Dissertação de Mestrado. Campinas: UNICAMP, 2006.

VFCO. Centro Oeste. Disponível em <http://vfco.brazilia.jor.br/>, acessado em 06 mar 2014.

WAIBEL, Léo. Capítulos de geografia tropical e do Brasil. $2^{\mathrm{a}}$ ed. Rio de Janeiro: IBGE, 1979.

\section{BIBLIOGRAFIA CONSULTADA}

AMADO, Janaina. "Construindo Mitos: a conquista do Oeste no Brasil e nos EUA”.

AUBERTIN, Catherine (Org.) Fronteiras. Brasília: Editora da UNB/ORSTON, 1988.

BARREIRA, Celene Cunha Monteiro Antunes. A região da estrada do boi: usos e abusos da natureza. Goiânia: Ed. da UFG, 1997.

O Papel de Pierre Monbeig na Análise de Ocupação da Frente Pioneira do CentroOeste (1930-1940). Boletim Goiano de Geografia. Goiânia: Ed. da UFG, 1997.

BARROSO, Gustavo. História Militar do Brasil. Rio de Janeiro: Biblioteca do Exército, 2000. 
BECKER, Bertha K. Crescimento econômico e estrutura espacial do Brasil. Revista Brasileira de Geografia. V. 34, n. 4, out. / dez. Rio de Janeiro: IBGE, 1972. p. 101 - 116.

BENKO, Georges e PEKQUEUR, Bernard. Os recursos de territórios e os territórios de recursos. GEOSUL Revista do Departamento de Geociências. v. 16, 32, UFSC. Florianópolis, Editora da UFSC, 2001. p.31-50.

BIBLIEX. O Mundo Hoje 1995/1996 - Anuário Econômico e Geopolítico Mundial. Rio de Janeiro: Biblioteca do Exército, 1997.

BRANDÃO, Antônio José da Costa. Almanach da Província de Goyaz: para o ano de 1886. Goiânia: Ed. da UFG, 1978.

BRASIL, Americano do. Pela história de Goiás: introdução seleção e notas de Humberto Crispim Borges. Goiânia: Ed. da UFG, 1980.

BRET, Bernard. A partilha do território e a desigualdade frente ao desenvolvimento: um problema de geografia política. Becker, Bertha K. e MIRANDA, Mariana. A Geografia Política do Desenvolvimento Sustentável. Rio de Janeiro: Editora da UFRJ, 1997.

CALÓGERAS, João Pandiá. Ideias Políticas de Pandiá Calógeras. Introdução, cronologia, notas, bibliografias e textos selecionados por Francisco Iglesias. Brasília, Senado Federal; Rio de Janeiro: Fundação Casa de Rui Barbosa, 1987.

CARLOS, Ana Fani Alessandri. A Cidade. São Paulo: Contexto, 2ª ed., 1994

CASTRO, Iná Elias de (org.). Geografia: conceitos e temas. Rio de Janeiro: Bertrand Brasil, 1995.

CHAVEIRO, Eguimar Felício. Goiânia, uma metrópole em travessia, Tese de Doutorado, 2001.

CONN, Stetson \& FAIRCHILD, Byron. A Estrutura de Defesa do Hemisfério Ocidental; tradução de Luís César Silveira da Fonseca. Rio de Janeiro: Biblioteca do Exército Editora, 2000.

CORRÊA, Roberto Lobato. Trajetórias Geográficas. Rio de Janeiro, Bertrand Brasil, 1997. Região e organização espacial. São Paulo: Ática, 1987.

COSTA, Wanderley Messias da. O Estado e as Políticas Territoriais do Brasil. São Paulo: Contexto, $4^{\text {a }}$ ed. 1995.

. Geografia Política e Geopolítica: Discursos sobre o Território e o Poder. São Paulo: Hucitec / Editora da Universidade de São Paulo, 1992.

FERREIRA, Joaquim Carvalho. Presidentes e governadores de Goiás. Goiânia: Ed. da UFG, 1980. 
FERREIRA NETO, Maria Cristina Nunes. A "Commissão Exploradora do Planalto Central do Brasil": a civilização a caminho do sertão. Estudos: Revista da Universidade Católica de Goiás. v. 29 (especial) p. 239 - 261. Goiânia: Ed. UCG, 1973.

GALVÃO, Marília Veloso; Faissol, Speridião. Divisão regional do Brasil. Revista Brasileira de Geografia, v. 31, n. 4, p. 179 - 218, out./dez. Rio de Janeiro: IBGE, 1969.

GEIGER, Pedro Pinchas. Esboço preliminar da divisão do Brasil nas chamadas regiões homogêneas. Revista Brasileira de Geografia. v. 29, n. 1, abr. / jun. Rio de Janeiro: IBGE, 1967. p. $59-64$.

GOMES, Paulo César da Costa. O conceito de região e sua discussão. CASTRO, Iná et al. Geografia: conceitos e temas. Rio de Janeiro: Bertrand Brasil, 1995.

Geografia e Modernidade. Rio de Janeiro: Bertrand Brasil, 1996.

GONÇALVES NETO, Wenceslau. Estado e Agricultura no Brasil. São Paulo: Hucitec, 1997.

GUERRA, Antônio Teixeira. A região geográfica e sua importância para o poder nacional. Revista Brasileira de Geografia, v. 26, n. 3, jul. / set. Rio de Janeiro: IBGE, 1964.

HAESBAERT, Rogério. Morte e vida da região: Antigos paradigmas e novas perspectivas da geografia regional. Porto Alegre: AGB, 2002.

. Territórios Alternativos. São Paulo: Contexto, 2002.

$\mathrm{n}^{\mathrm{o}} 1$.

Região, diversidade territorial e globalização. Geographia, UFF/EGG, 1999, ano 1

HOBSBAWN, Eric J. Nações e Nacionalismo desde 1780: programa mito e realidade. Rio de Janeiro: Paz e Terra, 1990.

IBGE. Geografia do Brasil. Fundação Instituto Brasileiro de Geografia e Estatística, Diretoria de Geociências. Rio de Janeiro: IBGE, 1988.

Geografia do Brasil - Região Centro-Oeste. Fundação Instituto Brasileiro de Geografia e Estatística, Diretoria de Geociências. Rio de Janeiro, SERGRAF - IBGE, 1977.

Recenseamentos gerais do Brasil: Goiás - Tocantins. Rio de Janeiro: IBGE, 2000.

JOHNSTON, R. J. Geografia e geógrafos: a geografia humana anglo - americana desde 1945; tradução de Oswaldo Bueno Amorim Filho. São Paulo: DIFEL, 1986.

KAISER, B. A região com objeto de estudo da geografia. Geografia Ativa. São Paulo: Difel, 1968.

LENCIONI, Sandra. Região e Geografia. São Paulo: EDUSP, 1999.

LESCANO, José Z. Introducción a la geopolítica. (El Perú y su concepción geopolítica). Lima, Horizonte, 1970. 
MARTINS, José de Souza. Fronteira - a degradação do outro nos confins do humano. Hucitec. São Paulo, 1997.

MATOS, Carlos de Meira. Uma Geopolítica Pan - Amazônica. Rio de Janeiro: Biblioteca do Exército, 1980.

. A Geopolítica e as projeções de poder. Rio de Janeiro: Biblioteca do Exército, 1977.

MAGNAGO, Angélica Alves. A divisão regional brasileira - uma revisão bibliográfica. Revista Brasileira de Geografia. V. 57, n. 4. Rio de Janeiro: IBGE, 1995, p 67 - 94.

MORAIS, Antônio Carlos Robert. Ideologias Geográficas: Espaço Cultura e Política no Brasil. São Paulo: Hucitec, $3^{\text {a }}$ Ed., 1996.

MÜLlER, Geraldo. Complexo Agroindustrial e Modernização Agrária. São Paulo, HUCITEC, 1989.

NETO, Antônio T. Os caminhos de ontem e de hoje em direção a Goiás-Tocantins. Boletim Goiano de Geografia. Pós-Graduação em Geografia, Curso de Geografia - IESA/ UFG, vol. 21, no 1, jan./ jun. 2001. p. 51-68.

Formação Territorial: Considerações sobre alguns aspectos geográficos, históricos e políticos. Boletim Goiano de Geografia. vol. 2, nº 2, IQG, Goiânia, 1982.

OLIVEIRA, Francisco de. Elegia para uma Re(li)gião. Rio de Janeiro: Paz e Terra, 1977.

PEREIRA, Mirlei Fachini Vicente. Redes, Sistemas de Transportes e as Novas Dinâmicas do Território no Período Atual: notas sobre o caso brasileiro. Revista Sociedade \& Natureza, Uberlândia, 21 (1): 121 - 129, ABR. 2009.

QUAINI, M. Marxismo e Geografia. Rio de Janeiro: Paz e Terra, 1979.

RAFESTIN, Claude. Por uma Geografia do Poder. São Paulo: Ática, 1993.

RATZEL, Frederico. Ratzel. São Paulo: Ática, organizado por A. C. R. Moraes, 1990.

SANTOS, Milton. Espaço e Método. São Paulo: Nobel, 1997.

Os Espaços da Globalização, Anais do $3^{\circ}$ Simpósio Nacional de Geografia Urbana. Rio de Janeiro: IBGE, 1993.

Por uma geografia nova. São Paulo: HUCITEC, 1985.

SEVERINO, Antônio Joaquim. Metodologia do Trabalho Científico. São Paulo: Cortez, 1998.

Planejamento estratégico. $2^{\mathrm{a} e d . ~ B r a s i ́ l i a: ~ E d i t o r a ~ d a ~ U n i v e r s i d a d e ~ d e ~ B r a s i ́ l i a, ~} 1981$. SILVA, Luiz Sérgio Duarte da. A construção de Brasília: modernidade e periferia. Goiânia: Ed. UFG, 1997. 
SILVA, Waldecyr Rosa da. A Globalização Econômica e o Brasil na “Aldeia Global”. Revista a Defesa Nacional - Revista de assuntos militares e estudo de problemas brasileiros. Rio de Janeiro: BIBLIEX. Ano LXXXVII - nº 791, Set, Out, Nov, Dez 2001.

SIMIELLI, Maria Elena. Geoatlas. São Paulo: Ática, 2002.

TRAVASSOS, Mário. Projeção continental do Brasil. $4^{\mathrm{a}}$ ed. São Paulo: Companhia Editora Nacional, 1947.

VALADARES, S. P. e AMADO, J. Passando dos Limites.Goiânia, Editora da UFG, 1995.

VALVERDE, Orlando. Estudo regional da Zona da Mata de Minas Gerais. Revista Brasileira de Geografia. V. 20, n. 3, jul / set. Rio de janeiro: IBGE, 1963. p 289 - 311.

VLACH, Vânia Rubia Farias. Estudo Preliminar Acerca dos Geopolíticos Militares Brasileiros. Terra Brasilis - Revista de História do Pensamento Geográfico no Brasil. Ano III - IV, N. 4 - 5 Território. Rio de Janeiro, 2002 - 2003.

VESENTINI, José Willian. A Capital da Geopolítica. 4ed. São Paulo: Ática, 1996. 


\section{ANEXOS}

1 - Principais Centros Colonizadores do Brasil no Século XVI: Baia de Todos os Santos (BA); Vila de Olinda (PE); São Vicente (SP) e Baia do Rio de Janeiro (RJ)
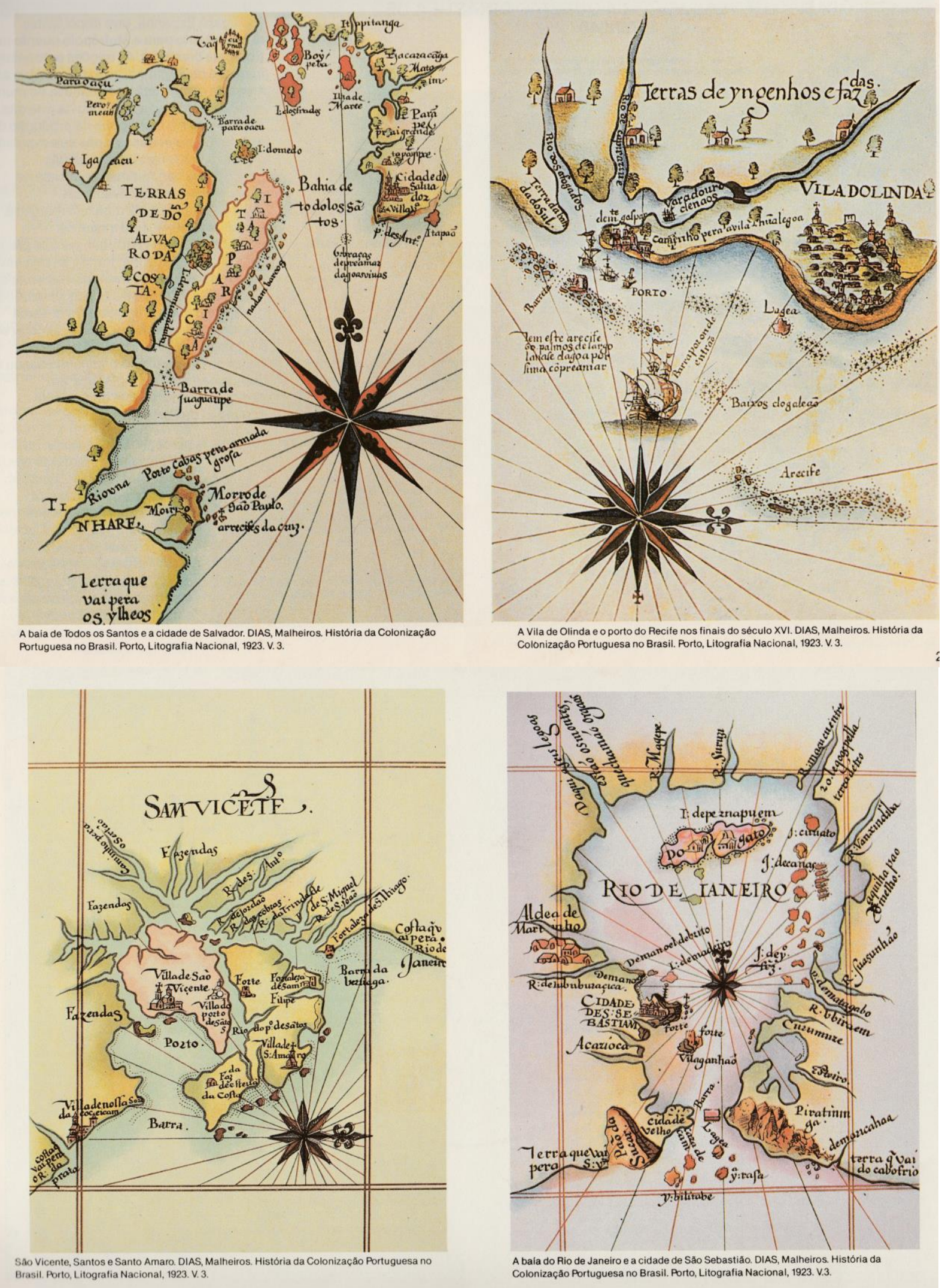

Fonte: Resende, 1987, p. 23. 
2 - Superintendências Regionais da RFFSA, de acordo com suas ferrovias de origem.

\begin{tabular}{|c|c|}
\hline FERROVIA DE ORIGEM & DIVISÃO REGIONAL RFFSA \\
\hline EFSLT & SR-12 \\
\hline RVC & SR-11 \\
\hline RFN & SR-1 \\
\hline VFFLB & SR \\
\hline VFCO & SR-8 \\
\hline EFL & SR-2, com trechos de bitola métrica da antiga EFCB \\
\hline EFCB & SR-4 \\
\hline EFSJ & SR-10 \\
\hline EF No B & SR-5 \\
\hline RVPSC & SR-9 \\
\hline EFDTC & SR-6 \\
\hline VFRGS & \\
\hline &
\end{tabular}

Fonte: VFCO, 2014. 
3 - Evolução da Rede Ferroviária Federal S/A (RFFSA): ferrovias, divisões e regionais.

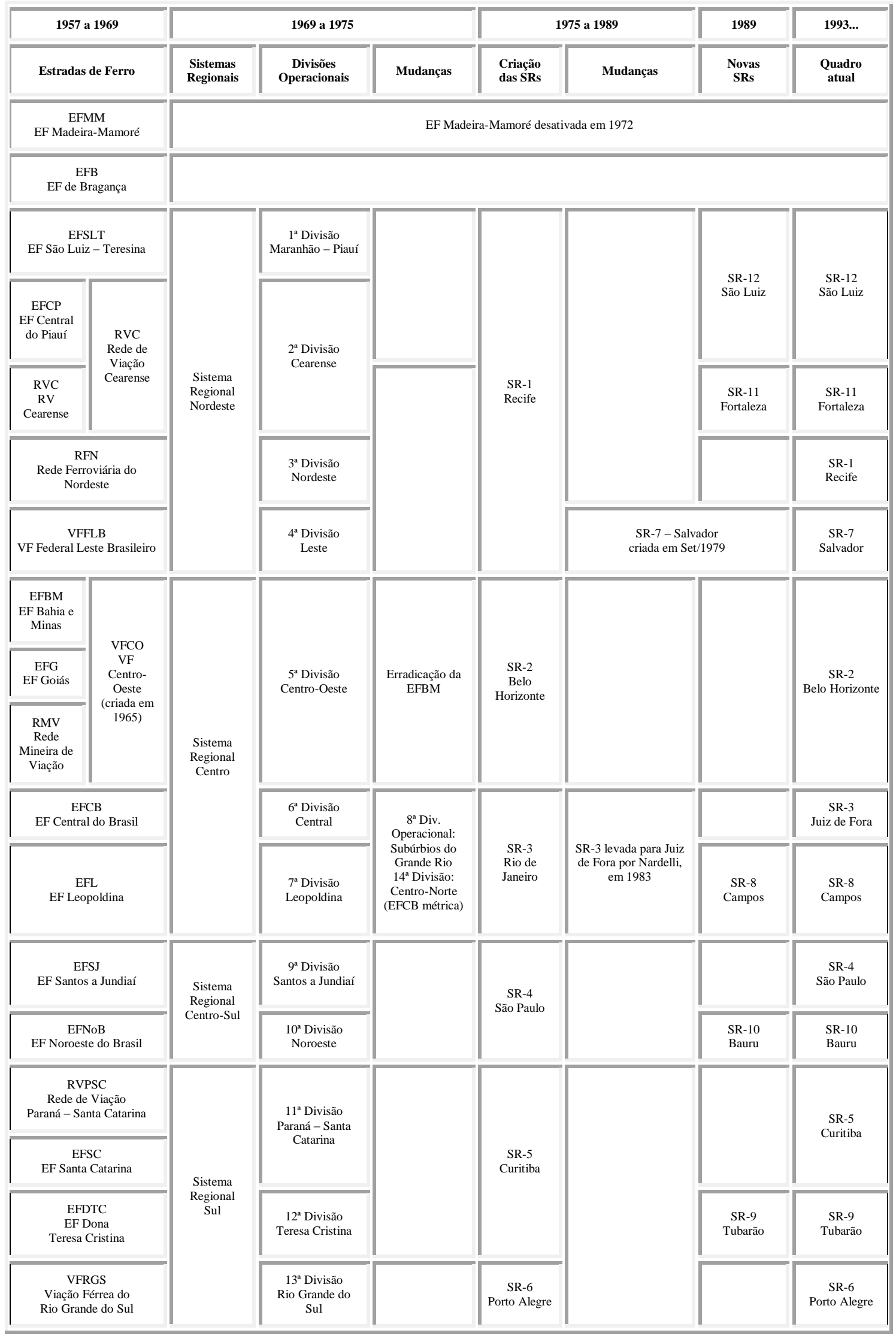

Fonte: VFCO, 2014 
4 - Tipos de locomotivas e vagões segundo da Associação Nacional dos Transportadores Ferroviários - ANTF

\section{Material rodante Locomotivas e Vagões}

\section{Informações do Setor - Material Rodante}

\section{Locomotivas}

As primeiras ideias para utilização do vapor para movimentação de veículos datam do século XVII, sendo construído por Richard Trevithick no País de Gales somente em 1804 um carro a vapor sobre trilhos. Em 1814 o inglês Geoge Stephenson apresentou a locomotiva "Blucher", e em 1825 fundou com outros sócios a firma Robert Stephenson \& Co., primeira fábrica de locomotivas do mundo.

Desta fábrica saíram a locomotiva "Locomotion" para a Stockton \& Darlington Railway, primeira ferrovia pública do mundo, e a famosa "Rocket", vencedora do concurso de Rainhill para a Liverpool \& Manchester Railway em 1829, que pelas suas características se firmaria como o ponto de partida das futuras locomotivas a vapor.

Daí em diante vários países seguiram o exemplo construindo ferrovias, inclusive o Brasil, que inaugurou por iniciativa do empresário Irineu Evangelista de Souza em 30 de abril de 1854 a Imperial Companhia de Navegação a Vapor - Estrada de Ferro de Petrópolis, mais conhecida como Estrada de Ferro Mauá, sendo utilizada para tracionar o trem inaugural a locomotiva 22-2T número 1, fabricada por William Fairbain \& Sons na Inglaterra. A locomotiva ganhou o nome "Baronesa", em homenagem à esposa de Irineu Evangelista de Souza, que nesta ocasião recebeu o título de Barão de Mauá, e atualmente está preservada como a peça mais importante do Museu do Trem, no Rio de Janeiro.

\section{Locomotivas a vapor}

As locomotivas a vapor utilizam o vapor sob pressão para acionar os êmbolos que transmitem o movimento por puxavantes e braçagens às rodas. A energia para produção do vapor na caldeira vem da fornalha localizada mais atrás, queimando combustível - carvão, lenha ou óleo - que fica armazenado no tender, junto com a água para reabastecimento constante da caldeira.

A caldeira é basicamente um tanque de aço resistente a altas pressões cheio d'água e com tubos interligando a fornalha à caixa de fumaça na parte da frente, por onde passa a chama para o aquecimento e produção do vapor.

$\mathrm{Na}$ parte superior um conjunto de válvulas colhe o vapor e o distribui para os cilindros onde vai acionar os êmbolos, escapando depois por um tubo Venturi dentro da caixa de fumaça para a chaminé e com isto aumentando a tiragem para manter intensa a chama na fornalha. Sendo a locomotiva equipada com superaquecedor o vapor, ao sair da caldeira, passa por uma serpentina de tubos em contato com a chama para aumentar sua temperatura e pressão, melhorando o rendimento.

Esquema de uma típica locomotiva a vapor: 


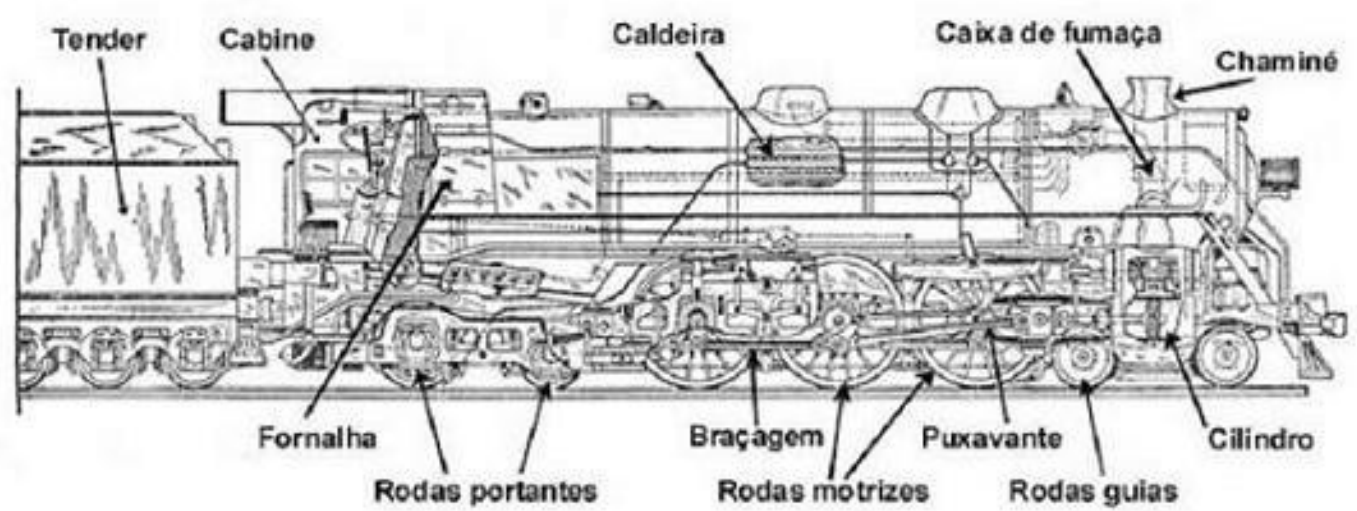

De acordo com o arranjo das rodas guias, motrizes e portantes, as locomotivas têm uma classificação, sendo mais comum a Whyte, adotada na Inglaterra, os EUA e também no Brasil.

Esquema das principais rodagens de locomotiva a vapor

\begin{tabular}{|c|c|c|c|}
\hline $\bar{O} \cdot \bar{O}$ & $2-2 \cdot 2$ & Oथख & $\begin{array}{l}2.6-2 \\
\text { Prairio }\end{array}$ \\
\hline $\mathrm{O} \cdot \mathrm{M}^{2}$ & $4-2-2$ & (घ) $(8)=0$ & Ten-Wheel \\
\hline (2B) & $0-4-0$ & $\mathrm{OT}_{1} \mathrm{C} / \mathrm{O}=\mathrm{O}$ & $\begin{array}{l}4-6-2 \\
\text { Pacific }\end{array}$ \\
\hline (ख) & 24.0 & $0=0(a, G)=0$ & $\begin{array}{l}4-6-4 \\
\text { Hudson }\end{array}$ \\
\hline (2) $\mathrm{O}=0$ & $\begin{array}{l}4.4-0 \\
\text { American }\end{array}$ & $(2)(9)(3)$ & $\begin{array}{l}2-8-0 \\
\text { Consolidation }\end{array}$ \\
\hline$O ( 2 ) \longdiv { 0 - 0 }$ & $\begin{array}{l}4-4 \cdot 2 \\
\text { Atlantic }\end{array}$ & 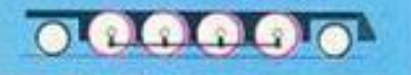 & $\begin{array}{l}2-8-2 \\
\text { Mikado }\end{array}$ \\
\hline (ख) & $0-6.0$ & $\mathrm{OQM(a)} \mathrm{O}=\mathrm{O}^{\mathrm{a}}$ & $\begin{array}{l}4-3-2 \\
\text { Mountain }\end{array}$ \\
\hline (2) & $\begin{array}{l}26-0 \\
\text { Mogul }\end{array}$ & 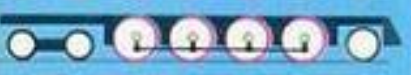 & $\begin{array}{l}2-8-4 \\
\text { Berkshire }\end{array}$ \\
\hline O(I) & $0-6-2$ & (घ) & $\begin{array}{l}2-10-0 \\
\text { Decapod }\end{array}$ \\
\hline
\end{tabular}

Nos EUA e na Europa outros tipos de locomotivas a vapor foram também desenvolvidos, com a utilização de turbinas para acionamento das rodas via engrenagens ou geradores e motores elétricos, mas acabaram sendo abandonados devido à complexidade e altos custos, principalmente depois do desenvolvimento das modernas locomotivas diesel.

\section{Locomotivas elétricas}

Durante a realização da Exposição Industrial de Berlim, em 1879, uma locomotiva elétrica circulou pela primeira vez, apresentada pelo engenheiro alemão Werner Von Siemens. Rapidamente vários países europeus adotaram a novidade eletrificando suas ferrovias.

No Brasil a tração elétrica foi empregada pela primeira pela Companhia Ferro Carril do Jardim Botânico, no Rio de Janeiro em 1892, e pela E. F. do Corcovado em 1910. Em 1922 iniciou-se a eletrificação da Companhia Paulista de Estradas de Ferro, e em 1937 da Central do Brasil, nas linhas de subúrbios no Rio de Janeiro.

Embora estendida a várias ferrovias brasileiras, a tração elétrica foi aos poucos sendo desativada devido à obsolescência dos equipamentos existentes e aos altos custos de manutenção dos equipamentos fixos, ficando restrita atualmente aos sistemas de transporte metropolitano nas principais capitais. A única linha de carga atualmente em operação é a cremalheira da MRS entre Piassaguera e Paranapiacaba, na serra do Mar em São Paulo. 
Locomotivas elétricas de cremalheira Hitachi, da MRS

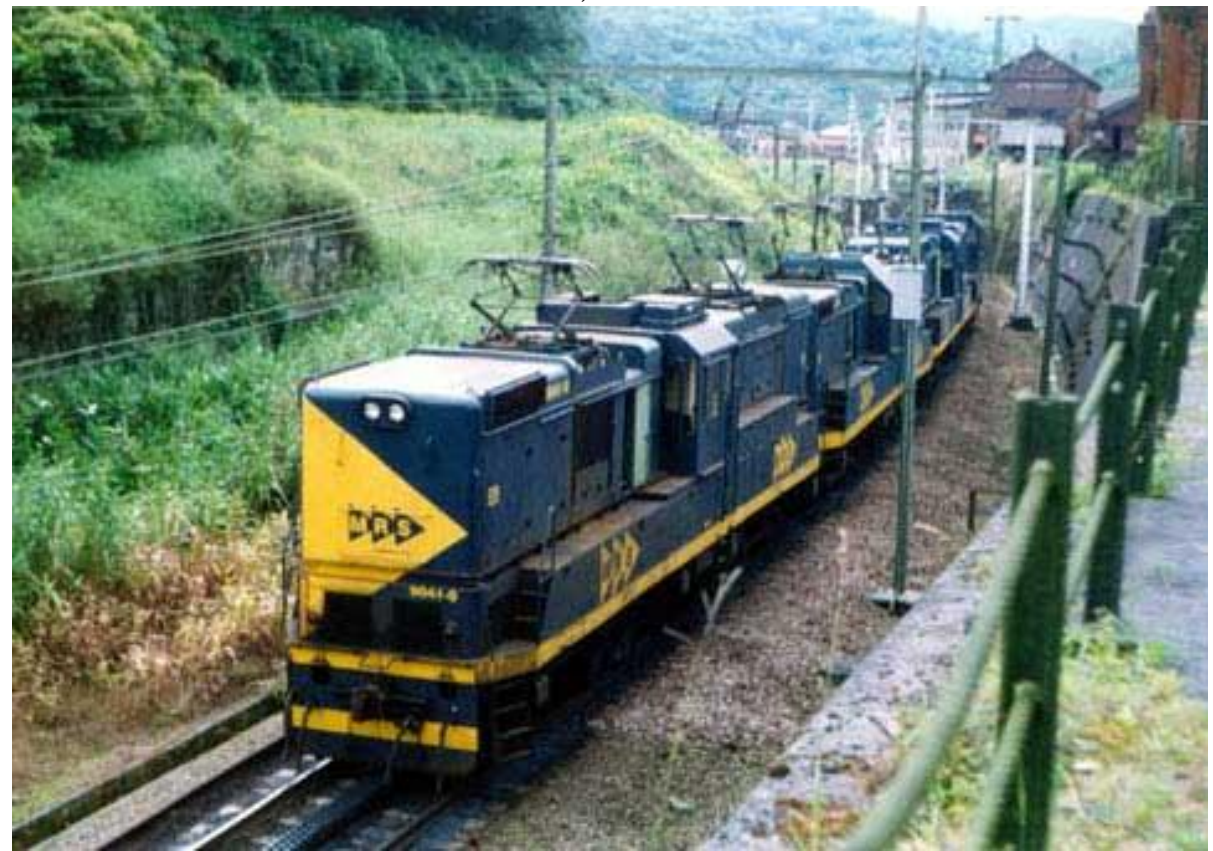

De uma forma geral as locomotivas elétricas captam a energia da rede aérea por um pantógrafo, ou do terceiro trilho por uma sapata lateral, e através de equipamentos de controle alimenta os motores de tração localizados nos truques. O mesmo princípio se aplica aos trens unidade de passageiros utilizados nos sistemas de transporte metropolitano.

No Brasil a maioria dos sistemas de eletrificação com rede aérea opera com corrente contínua a $3.000 \mathrm{~V}$, e com terceiro trilho com corrente contínua a $750 \mathrm{~V}$. Na E. F. do Corcovado a corrente é alternada trifásica, a $750 \mathrm{~V}$.

\section{Locomotivas diesel-elétricas}

Embora inventados desde o final do século XIX respectivamente por Nikolaus A. Otto e Rudolph Diesel os motores a gasolina e diesel de início não tiveram aplicação comercial na tração ferroviária, devido principalmente ao tamanho e peso excessivos e também pela dificuldade de transmissão do movimento e do torque às rodas.

Somente em 1925 foi apresentada pela General Electric associada à Ingersoll-Rand uma locomotiva diesel-elétrica de manobras, fabricada para a Central of New Jersey Railroad. A partir daí a tração diesel-elétrica se tornou um sucesso, especialmente nas ferrovias de transporte pesado de cargas dos EUA, praticamente eliminando o vapor a partir da década de 1950. No Brasil a primeira ferrovia a ter locomotivas diesel-elétricas foi a Viação Férrea Federal Leste Brasileiro, na Bahia, recebendo 3 locomotivas 1-B-B1 fabricadas pela English Electric em 1938, e a primeira ferrovia a dar início efetivo à dieselisação foi a E. F. Central do Brasil, a partir de 1943.

Nas locomotivas diesel-elétricas o motor diesel aciona um gerador que produz a energia elétrica destinada aos motores de tração localizados nos truques e acoplados às rodas motrizes por engrenagens. Especialmente a partir da década de 1970 passou-se a utilizar o alternador, produzindo corrente alternada a ser retificada e enviada aos motores de tração de corrente contínua, sendo amplamente utilizada no Brasil desde então. Uma tecnologia mais recente é a dos motores de tração a corrente alternada, já comum em diversas ferrovias da América do Norte, mas ainda não utilizada no Brasil. 
Esquema de uma típica locomotiva diesel-elétrica

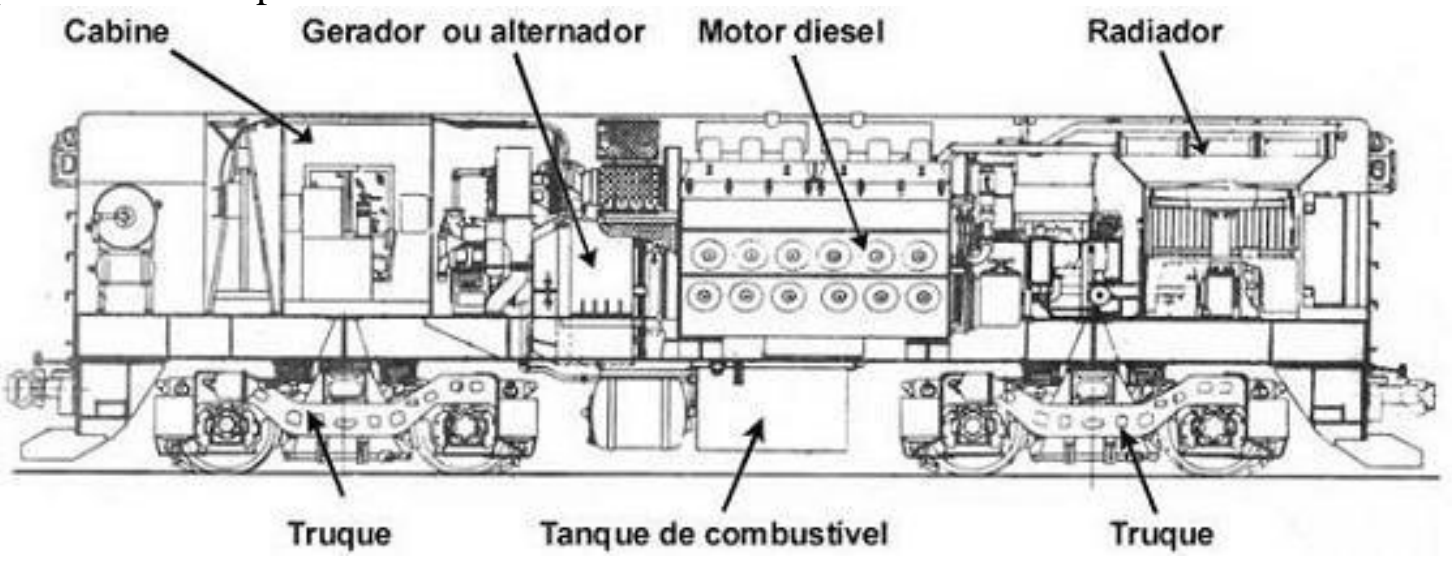

Paralelamente foi sendo desenvolvida na Europa, especialmente na Alemanha, a tração dieselhidráulica, onde o motor diesel aciona um conversor de torque hidráulico acoplado aos eixos de dada truque. Principalmente entre as décadas de 1950 e 70 tivemos no Brasil vários exemplos de utilização deste tipo de locomotiva, estando atualmente limitado a algumas unidades de manobras em indústrias.

De acordo com o arranjo das rodas nos truques as locomotivas têm uma classificação, atribuindo-se letra às rodas motrizes e número às rodas livres sem tração. Esta classificação também se aplica às locomotivas elétricas.

Esquema das principais rodagens de locomotivas diesel-elétricas

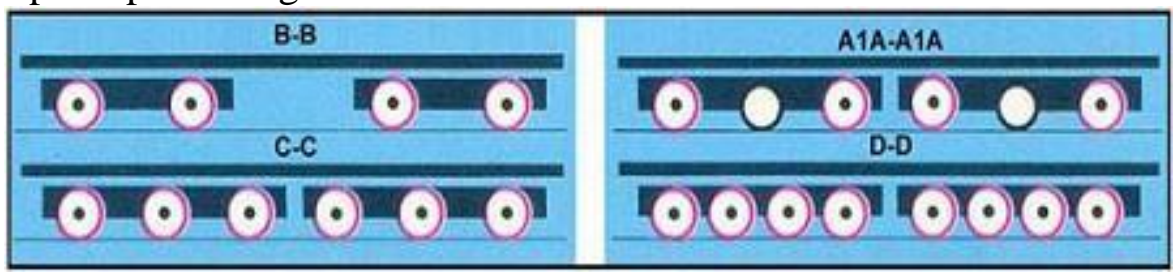

As fotos seguintes apresentam alguns dos principais modelos de locomotivas diesel-elétricas em operação em várias ferrovias do Brasil.

Locomotiva GM modelo G12 da Ferropar, com rodagem B-B

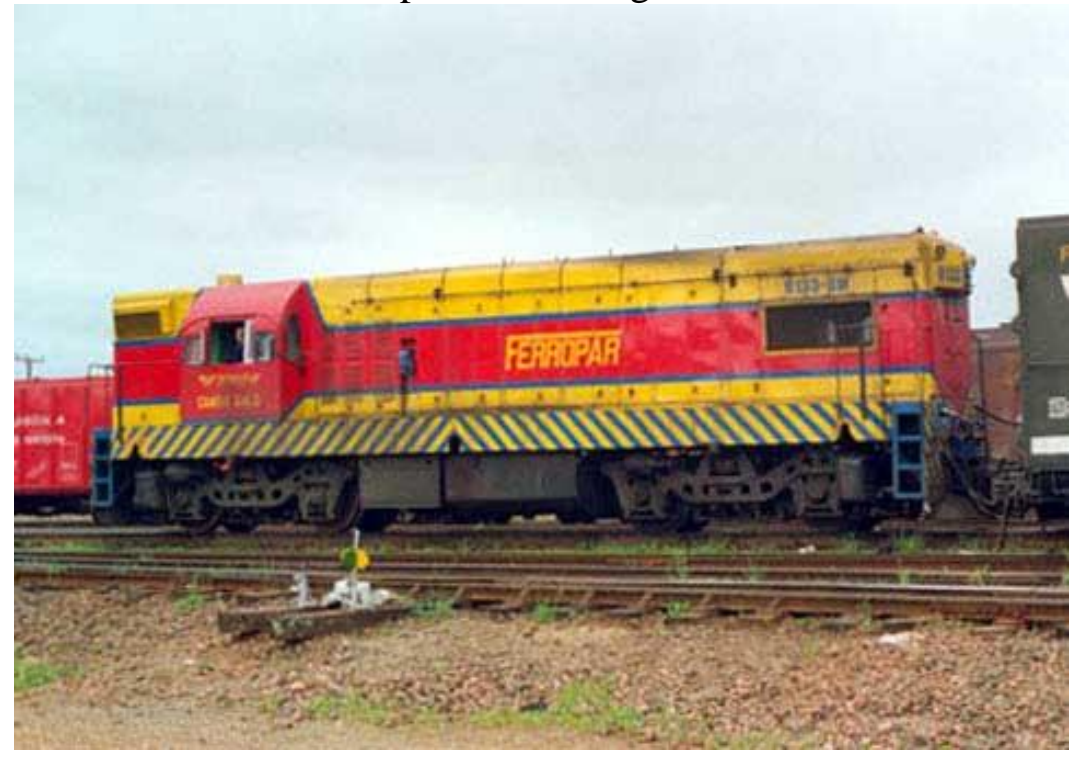


Locomotiva GM modelo G12 da FTC, com rodagem B-B

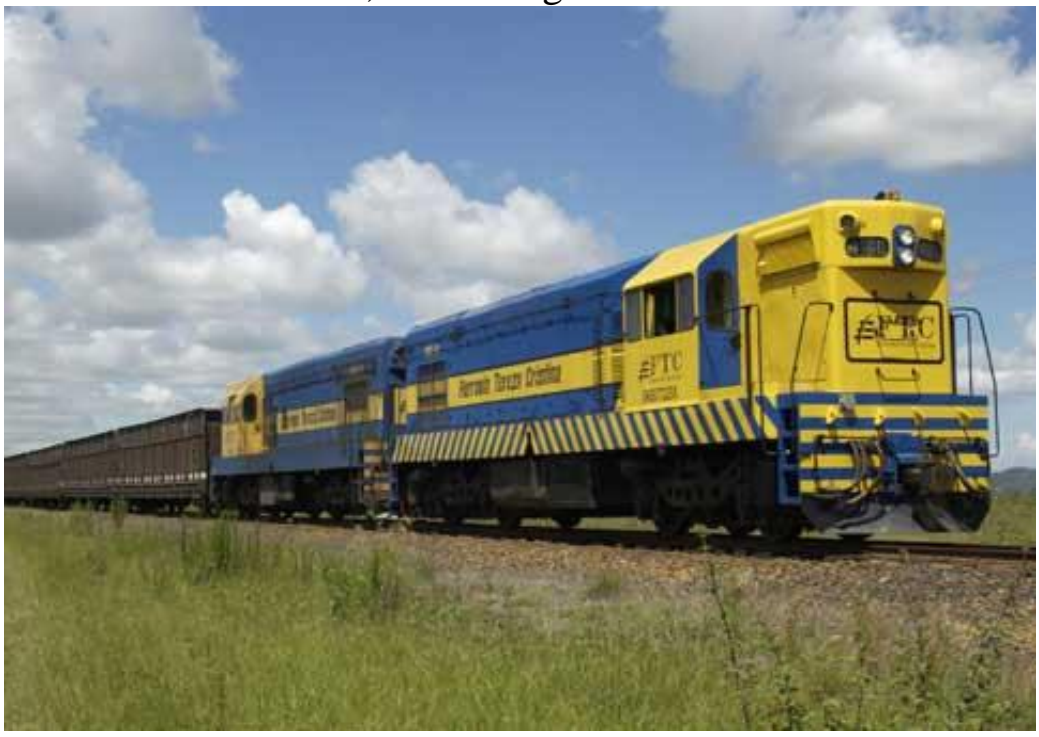

Locomotiva Macosa modelo G22U da ALL, com rodagem B-B

Locomotiva GE modelo U20C da Ferroban, com rodagem C-C

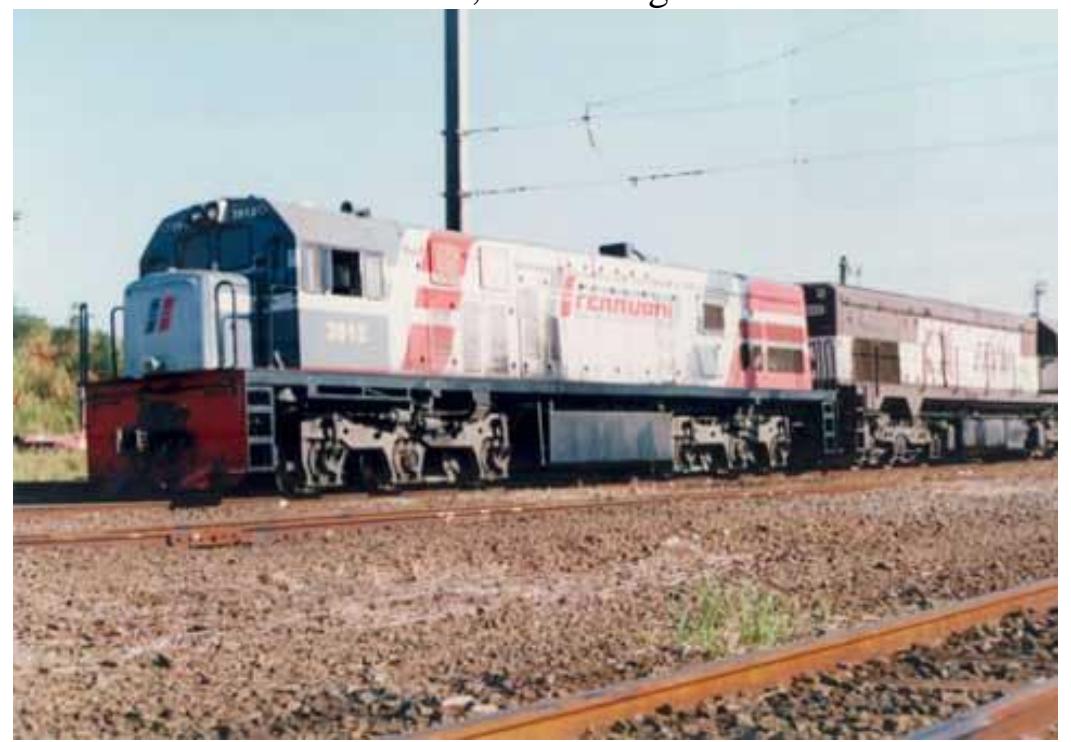


Locomotiva GE modelo C30-7 da ALL, com rodagem C-C

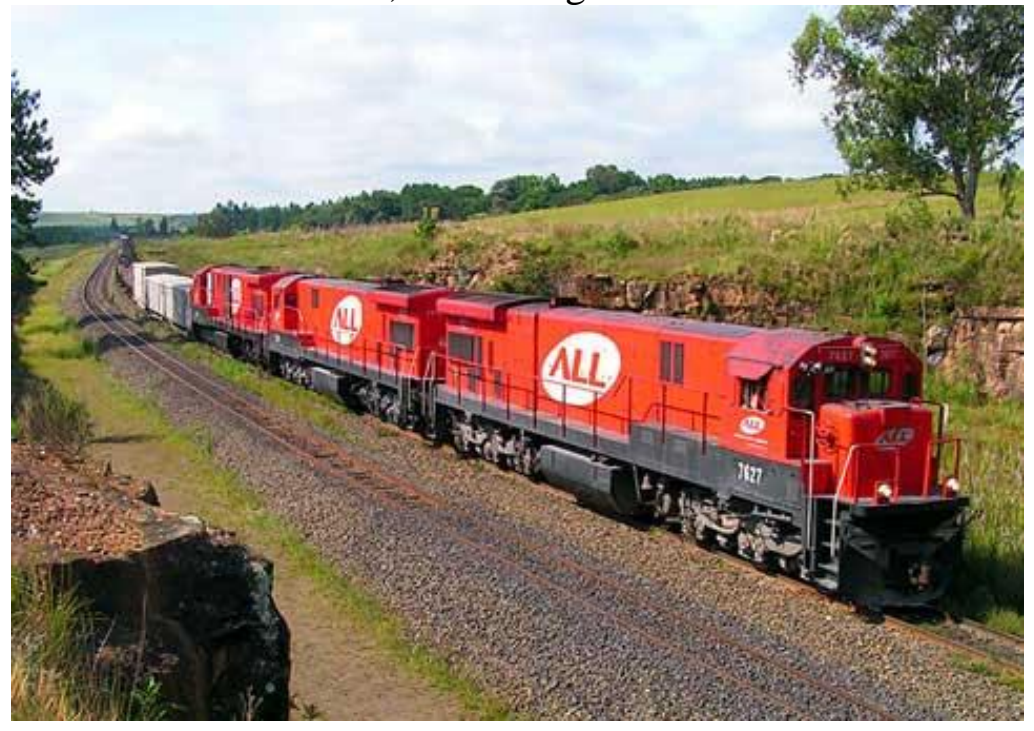

Locomotiva GE modelo C30-7A da Ferronorte, com rodagem C-C

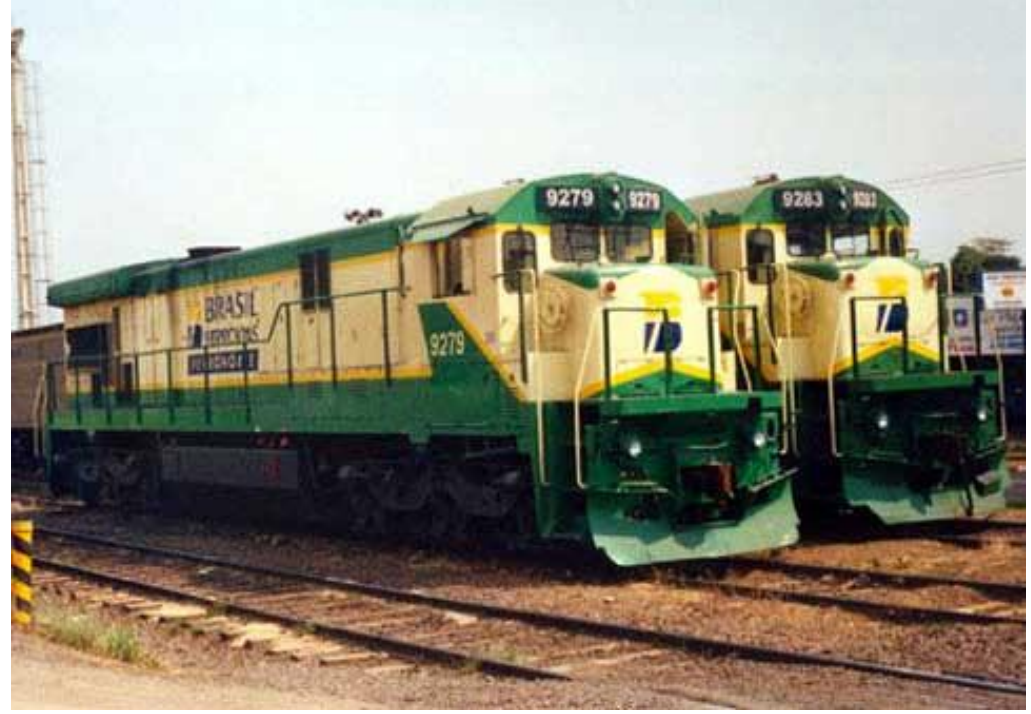

Locomotiva Macosa modelo GT26CU-2 da FCA, com rodagem C-C

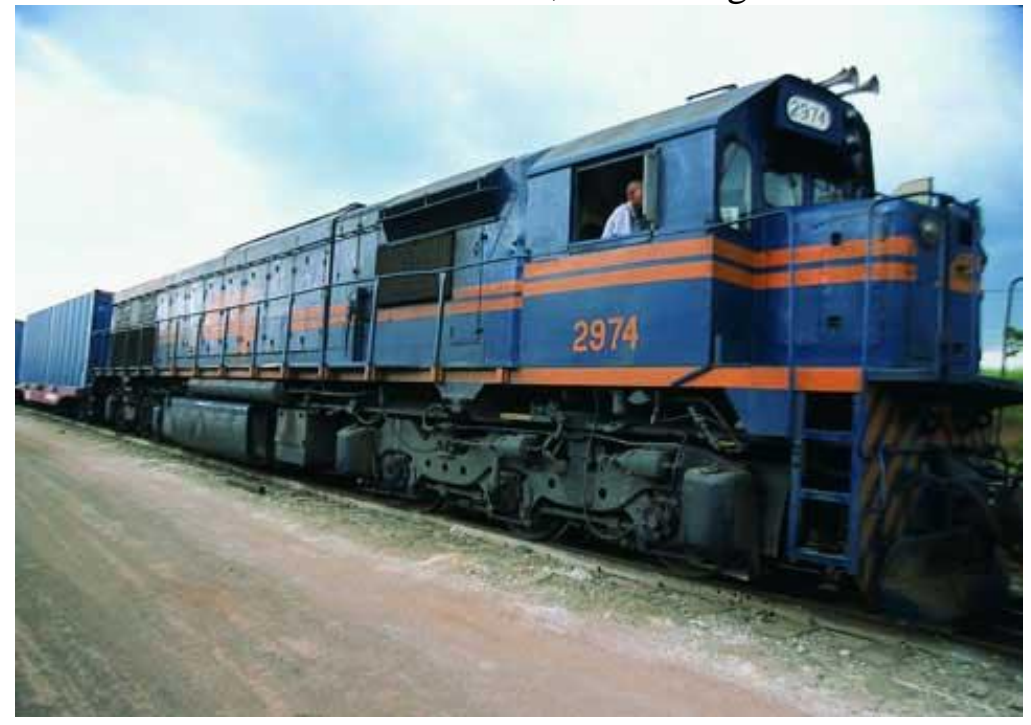


Locomotiva GM modelo SD40-3MP da MRS, com rodagem C-C

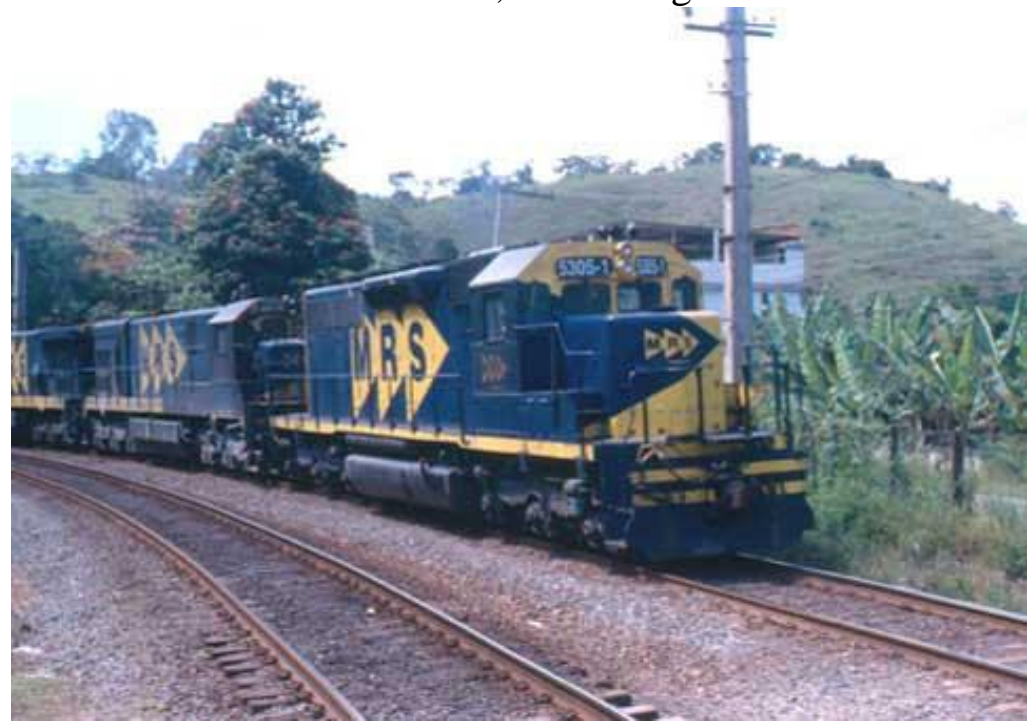

Locomotiva GE modelo C44-9WM da EFC, com rodagem C-C

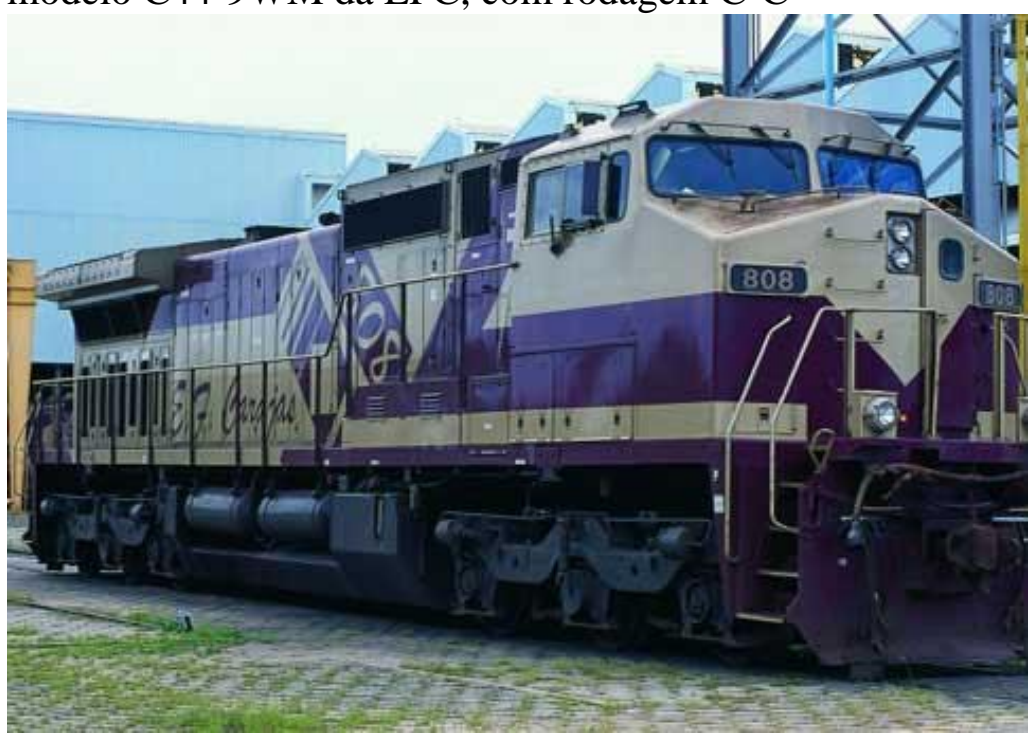

Locomotiva GE modelo C44-9WM da Ferronorte, com rodagem C-C

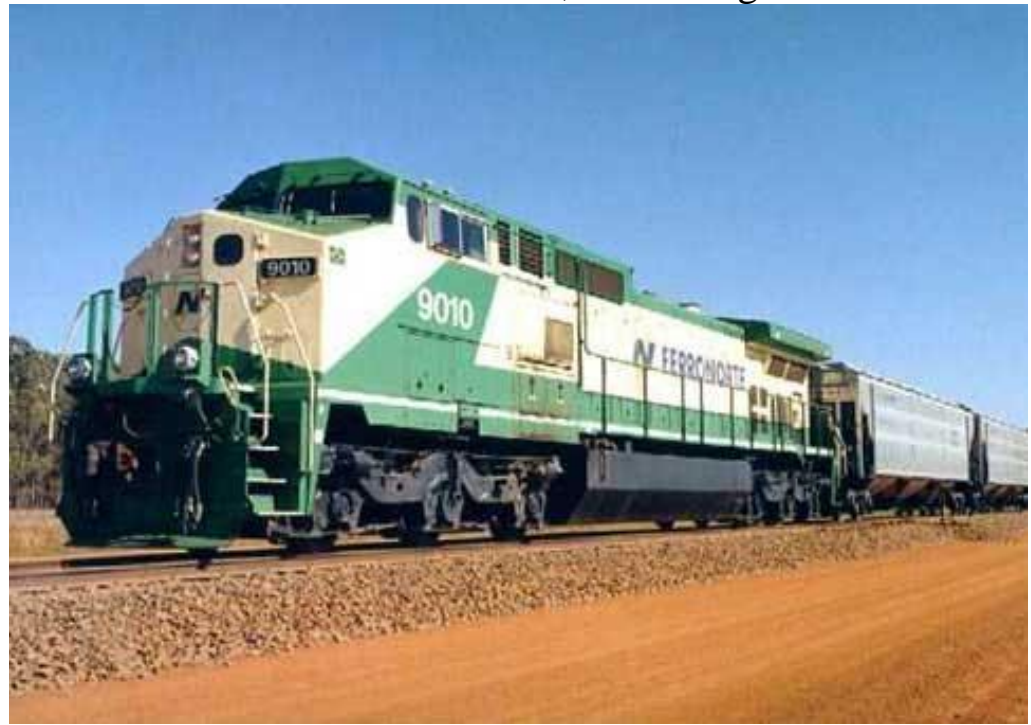


Locomotiva GM modelo DDM45 da EFVM, com rodagem D-D

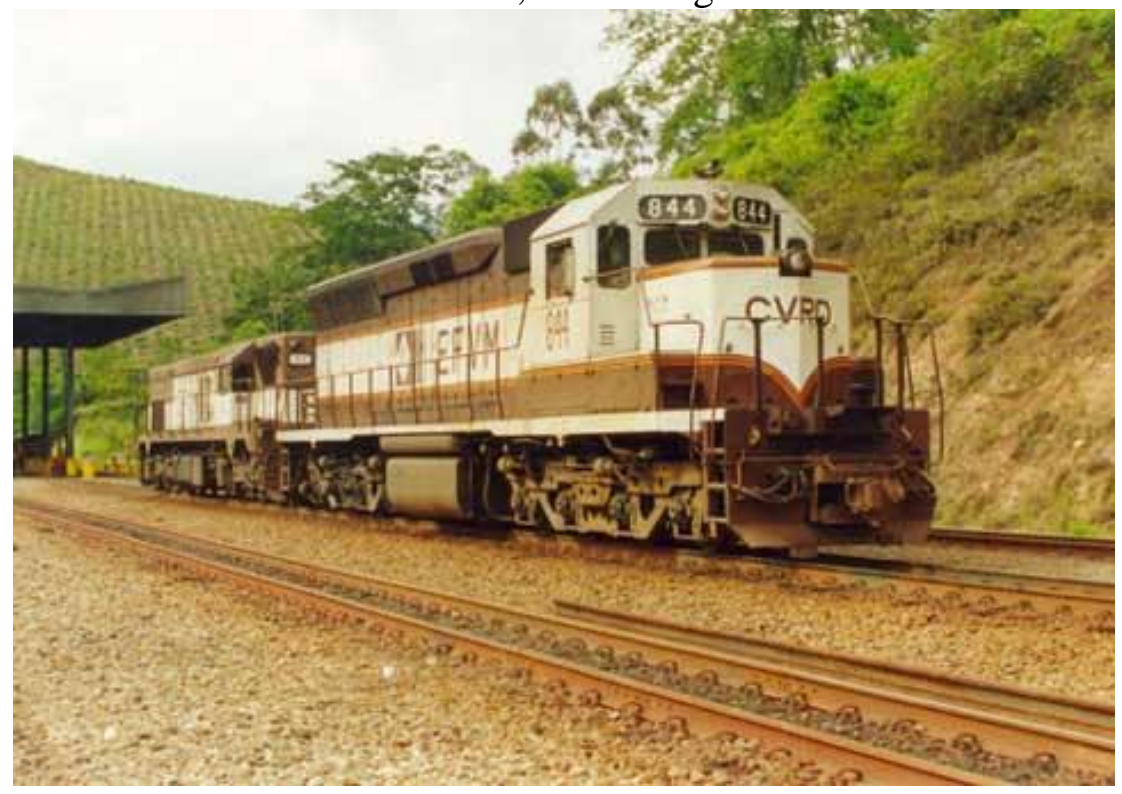

Locomotiva GE modelo BB36-7 da EFVM, com rodagem $\mathrm{B}+\mathrm{B}-\mathrm{B}+\mathrm{B}$

\section{Vagões}

A norma brasileira de classificação de vagões (NBR 11691) estabelece que a classificação de vagões seja feita através de três letras e sete números, como mostrado abaixo:

\section{GPR - 623053 - 9 \\ Bloco I Bloco II Dígito \\ Verificador}

No bloco I, a primeira letra identifica o tipo de vagão, e a segundo seu subtipo. São essas duas letras que orientam a classificação geral de vagões abaixo mostrada. A terceira letra, encontrável apenas nas figuras aqui disponibilizadas, identifica a denominada manga do eixo, que, por seu turno, limita o peso bruto máximo, de cada vagão. Para bitola métrica, as mangas variam de A a $\mathrm{G}$ (pesos brutos máximos de 30.0000 a $130.000 \mathrm{kgf}$, respectivamente); na bitola larga, as mangas variam de P a U (pesos brutos máximos de 47.0000 a 130.000 kgf, respectivamente). 
Assim, para o caso antes exemplificado, o significado seria:

- G: vagão tipo gôndola;

- P: com bordas fixas e portas laterais;

- R: de bitola larga, com peso bruto máximo de $80.000 \mathrm{kgf}$.

A numeração propriamente dita, bloco II do exemplo antes citado, está relacionada ao proprietário do vagão, que, ao tempo de elaboração da norma, subdividia-se em:

- Frota particular: 000001 a 099999;

- CVRD: 100000 a 299999;

- Fepasa: 300000 a 599999;

- RFFSA: 600000 a 999999.

Finalmente, quanto ao dígito verificador, último elemento do exemplo antes citado, seu cálculo obedece à seguinte marcha:

- multiplicação de cada algarismo, da esquerda para a direita, por sete, por seis, por cinco e assim sucessivamente;

- soma das multiplicações;

v divisão do resultado da soma por onze;

- subtração de onze menos o resto da divisão (se houver).

Conhecidos os critérios de classificação, apresentam-se em seguida os tipos de vagões mais usados no Brasil, alguns deles com links para fotos e desenhos técnicos.

Vagões tipo fechado - para granéis sólidos, ensacados, caixarias, cargas unitizadas e transporte de produtos em geral que não podem ser expostos ao tempo:

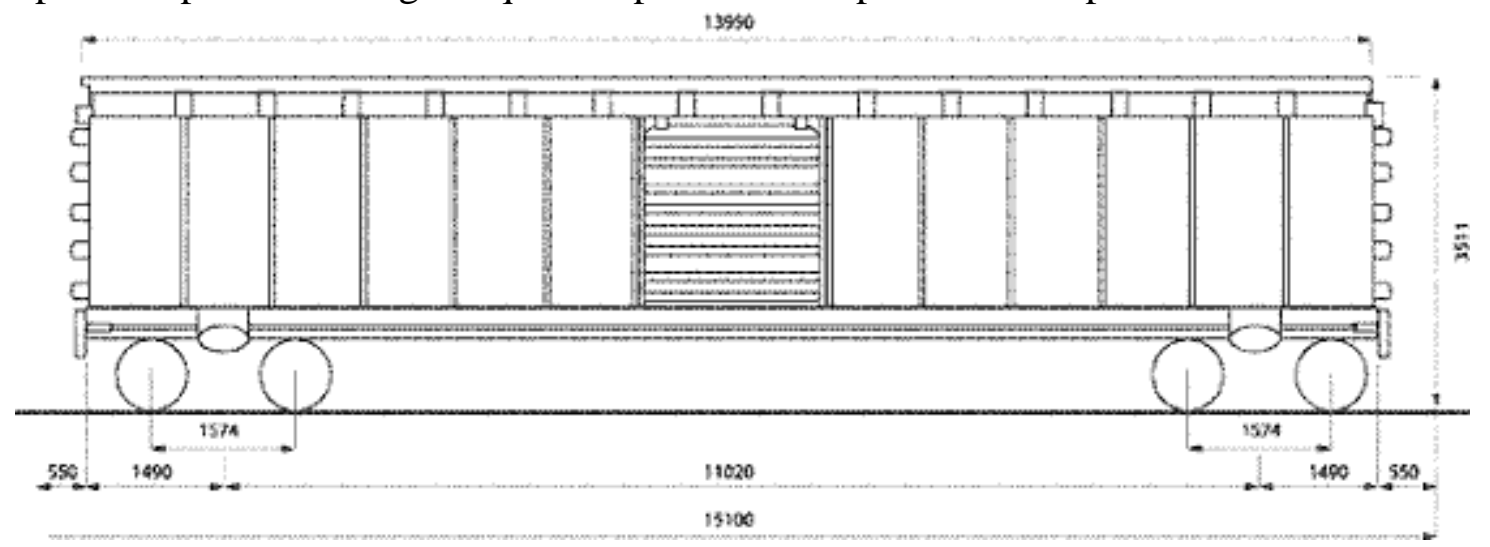

FR - Convencional, caixa metálica com revestimento

FS - Convencional, caixa metálica sem revestimento

FM - Convencional, caixa de madeira

FE - Com escotilhas e portas plug

FH - Com escotilhas, tremonhas no assoalho e portas plug

FL - Com laterais corrediças (all-door)

FP - Com escotilhas, portas basculantes, fundo em lombo de camelo

FV - Ventilado

FQ - Outros tipos

Vagões tipo gôndola - para granéis sólidos e produtos diversos que podem ser expostos ao tempo: 


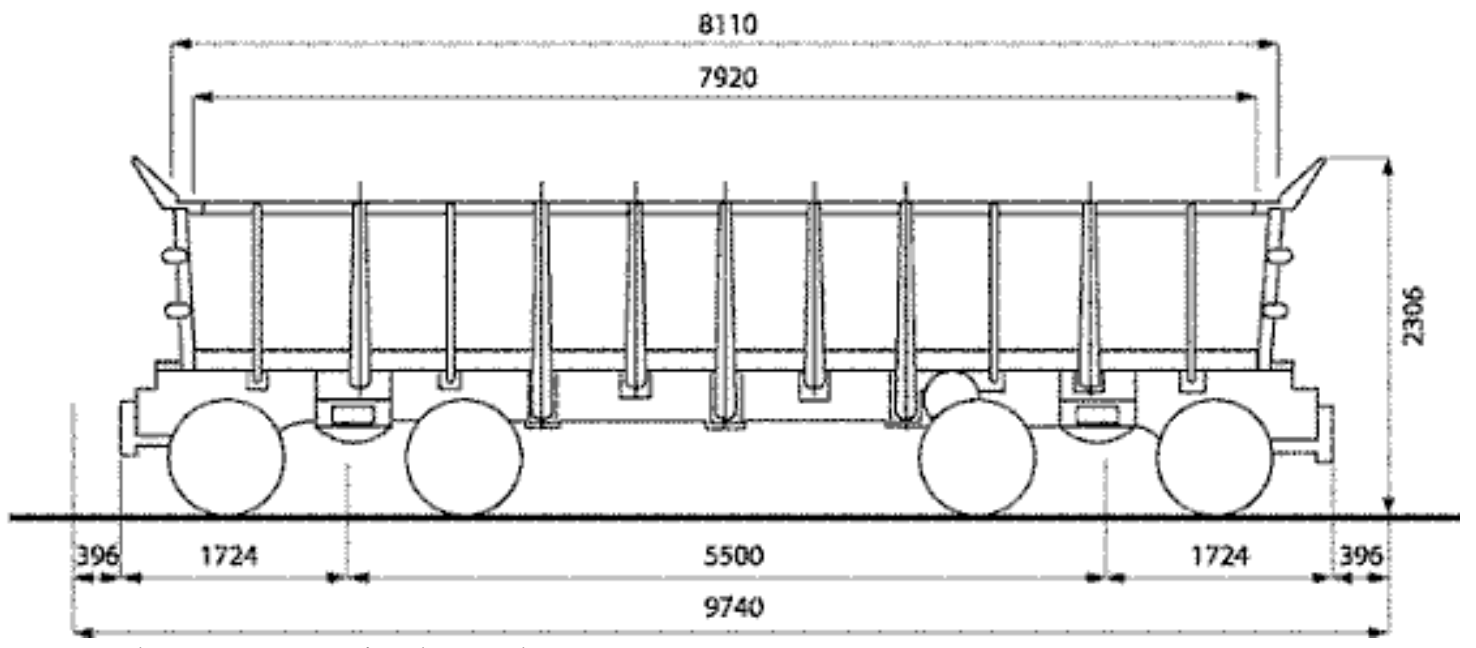

GD - Para descarga em giradores de vagão

GP - Com bordas fixas e portas laterais

GF - Com bordas fixas e fundo móvel (drop - bottom)

GM - Com bordas fixas e cobertura móvel

GT - Com bordas tombantes

GS - Com semi-bordas tombantes

$\mathrm{GH}$ - Com bordas Basculantes ou semi-tombantes com fundo em lombo de camelo

GC - Com bordas tombantes e cobertura móvel

GB - Basculante

GQ - Outros tipos

Vagões tipo hopper - fechados para granéis corrosivos e granéis sólidos que não podem ser expostos ao tempo e abertos para os granéis que podem ser expostos ao tempo:

HF - Fechado convencional

HP - Fechado com proteção anticorrosiva

HE - Tanque (center-flow) com proteção anticorrosiva

HT - Tanque (center-flow) convencional

HA - Aberto

HQ - outros tipos

Vagões tipo isotérmico - produtos congelados em geral:

IC - Convencional com bancos de gelo

IF - com unidade frigorífica

IQ - Outros tipos

No bloco I, a primeira letra identifica o tipo de vagão, e a segundo seu subtipo. São essas duas letras que orientam a classificação geral de vagões abaixo mostrada. A terceira letra, encontrável apenas nas figuras aqui disponibilizadas, identifica a denominada manga do eixo, que, por seu turno, limita o peso bruto máximo, de cada vagão. Para bitola métrica, as mangas variam de $\mathrm{A}$ a $\mathrm{G}$ (pesos brutos máximos de 30.0000 a $130.000 \mathrm{kgf}$, respectivamente); na bitola larga, as mangas variam de $\mathrm{P}$ a U (pesos brutos máximos de 47.0000 a $130.000 \mathrm{kgf}$, respectivamente).

Assim, para o caso antes exemplificado, o significado seria:

- G: vagão tipo gôndola;

- P: com bordas fixas e portas laterais;

- R: de bitola larga, com peso bruto máximo de $80.000 \mathrm{kgf}$. 
A numeração propriamente dita, bloco II do exemplo antes citado, está relacionada ao proprietário do vagão, que, ao tempo de elaboração da norma, subdividia-se em:

- Frota particular: 000001 a 099999;

- CVRD: 100000 a 299999;

- Fepasa: 300000 a 599999;

- RFFSA: 600000 a 999999.

Finalmente, quanto ao dígito verificador, último elemento do exemplo antes citado, seu cálculo obedece à seguinte marcha:

- multiplicação de cada algarismo, da esquerda para a direita, por sete, por seis, por cinco e assim sucessivamente;

- soma das multiplicações;

- divisão do resultado da soma por onze;

- subtração de onze menos o resto da divisão (se houver).

Conhecidos os critérios de classificação, apresentam-se em seguida os tipos de vagões mais usados no Brasil, alguns deles com links para fotos e desenhos técnicos.

Vagões tipo fechado - para granéis sólidos, ensacados, caixarias, cargas unitizadas e transporte de produtos em geral que não podem ser expostos ao tempo:

FR - Convencional, caixa metálica com revestimento

FS - Convencional, caixa metálica sem revestimento

FM - Convencional, caixa de madeira

FE - Com escotilhas e portas plug

FH - Com escotilhas, tremonhas no assoalho e portas plug

FL - Com laterais corrediças (all-door)

FP - Com escotilhas, portas basculantes, fundo em lombo de camelo

FV - Ventilado

FQ - Outros tipos

Vagões tipo gôndola - para granéis sólidos e produtos diversos que podem ser expostos ao tempo:

GD - Para descarga em giradores de vagão

GP - Com bordas fixas e portas laterais

GF - Com bordas fixas e fundo móvel (drop - bottom)

GM - Com bordas fixas e cobertura móvel

GT - Com bordas tombantes

GS - Com semi-bordas tombantes

$\mathrm{GH}$ - Com bordas Basculantes ou semi-tombantes com fundo em lombo de camelo

GC - Com bordas tombantes e cobertura móvel

GB - Basculante

GQ - Outros tipos

Vagões tipo hopper - fechados para granéis corrosivos e granéis sólidos que não podem ser expostos ao tempo e abertos para os granéis que podem ser expostos ao tempo:

HF - Fechado convencional

HP - Fechado com proteção anticorrosiva

HE - Tanque (center-flow) com proteção anticorrosiva

HT - Tanque (center-flow) convencional

HA - Aberto

HQ - outros tipos

Vagões tipo isotérmico - produtos congelados em geral

IC - Convencional com bancos de gelo 
IF - com unidade frigorífica

IQ - Outros tipos

Vagões tipo plataforma - contêineres, produtos siderúrgicos, grandes volumes, madeira, peças de grandes dimensões:

PM - Convencional com piso de madeira

PE - Convencional com piso metálico

PD - Convencional com dispositivo para contêineres

PC - Para contêineres

PR - Com estrado rebaixado

PG - Para serviço piggyback

PP - Com cabeceira (bulkhead)

PB - Para bobinas

PA - Com dois pavimentos para automóveis

PH - Com abertura telescópica

PQ - Outros tipos de vagão plataforma

Vagões tipo tanque - cimento a granel, derivados de petróleo claros e líquidos não corrosivos em geral:

TC - Convencional

TS - Com serpentinas para aquecimento

TP - Para produtos pulverulentos

$\mathrm{TF}$ - Para fertilizantes

TA - para ácidos e líquidos corrosivos

TG - para gás liquefeito de petróleo

TQ - Outros tipos

Vagões especiais - produtos com características de transporte bem distintas das anteriores:

ST - Torpedo (produtos siderúrgicos de alta temperatura)

SB - Basculante

SP - Plataforma para lingotes, placas de aço, etc.

SG - Gôndolas para sucata, escórias, etc.

SQ - Outros tipos

Fonte: ANTF. Material Rodante: locomotivas e vagões. Disponível em <http://www.antf.org.brindex.php/ material-rodante>, acessado em 27 jun. 2014. 
3 - Tipos de vagões fabricados pela Amisted Maxion

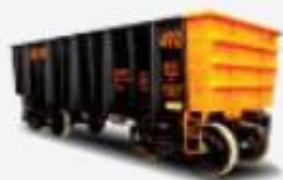

Gôndola

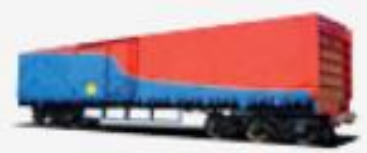

Multicarga

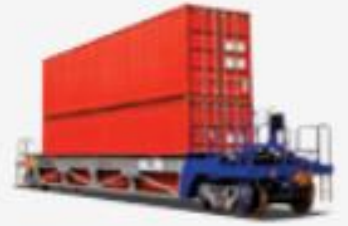

AMAX Top

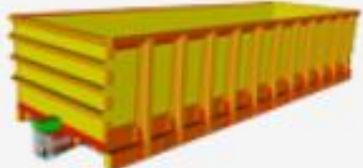

AMAX Mine

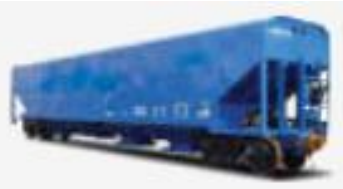

Hopper

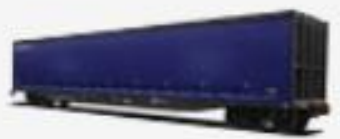

All Dor

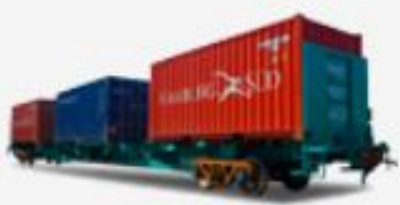

AMAX Long

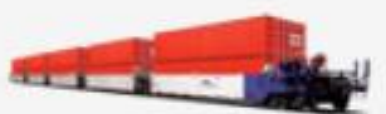

PentamaX

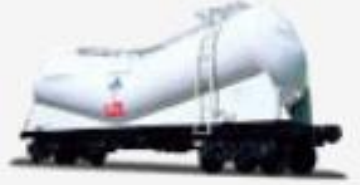

\section{Tanque}

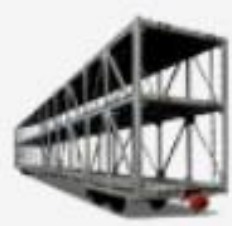

Cegonheiro

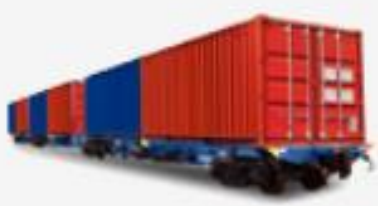

AMAX Flex

Fonte: AMISTED MAXION. Vagões. Disponível em <http://www.amsted-maxion.com.br/negocios_ferroviario _vagoes.php>, acessado em 27 jun. 2014. 